UNITED STATES DEPARTMENT OF THE INTERIOR

GEOLOGICAL SURVEY

\title{
4th International Symposium on Environmental Geochemistry
}

\section{Program with Abstracts}

By

Richard B. Wanty, Sherman P. Marsh, and Larry P. Gough

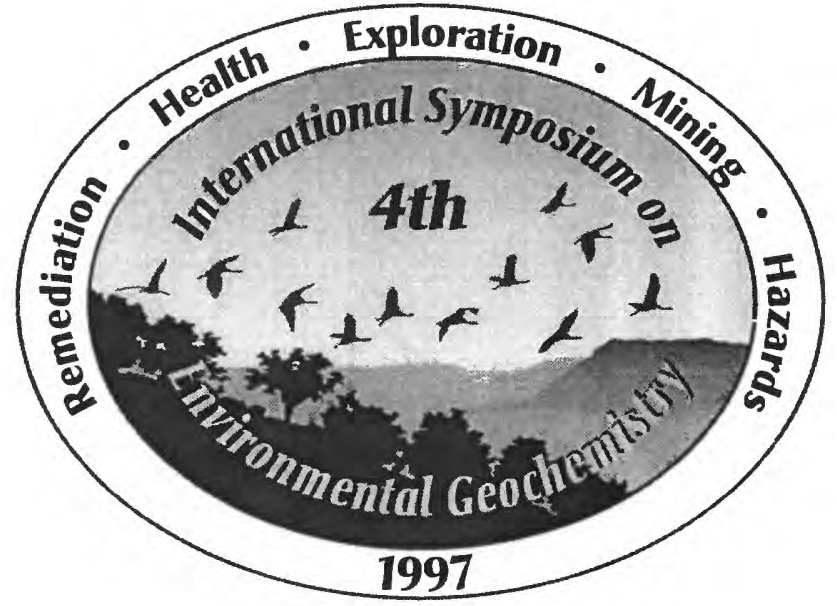

Open File Report 97-496

1997

The use of trade names in this report is for descriptive purposes only and does not constitute endorsement by the U.S. Geological Survey.

This report is preliminary and has not been edited or reviewed for conformity with U.S. Geological Survey standards and nomenclature. 


\section{Welcome to the 4th International Symposium on Environmental Geochemistry}

Welcome to colorful Colorado. This Rocky Mountain valley is an area once used to train soldiers of the 10th Mountain Division for Alpine combat in Europe during World War II. After the war, one of those soldiers came back with the dream of starting a ski area. In 1962, Vail opened and has grown into the largest, single-mountain ski resort in North America. During your stay we hope you will be able to visit the surrounding regions and enjoy American hospitality, food, and beautiful scenery.

It is an honor to host the 4th International Symposium on Environmental Geochemistry and we are eager for you to have a successful and productive conference. You can rest assured that every member of the Organizing Committee will see to accommodating your needs. Details of the scientific program and social events are given in the following pages. If you need assistance or have any questions, please feel free to go to the Registration Desk or ask any Organizing Committee member.

The support from sponsors, exhibitors, and attendees is gratefully acknowledged. A special thank you is extended to the Association of Exploration Geochemists, the Society for Environmental Geochemistry and Health, and the International Association of Geochemistry and Cosmochemistry for their interest and financial support. The United States Geological Survey also gave significant financial support in allowing members of the Organizing Committee time to devote to the Symposium.

The Organizing Committee

This proceedings volume is published as U.S. Geological Survey Open-File Report OF97-496. Literature citations can appear as follows:

Amacher, M.C., Kotuby-Amacher, J., and Brown, R.W., 1997, Reactions and transport of copper in headwater streams receiving acid rock drainage, in, Wanty, R.B., Marsh, S.P., and Gough, L.P., eds., 4th International Symposium on Environmental Geochemistry Proceedings: U.S. Geological Survey Open-File Report OF97496, $100 \mathrm{pp}$.

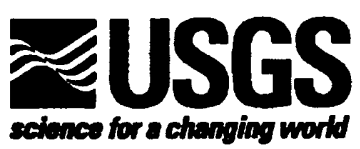

United States Geological Survey

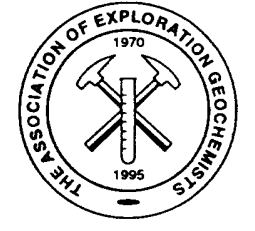

The Association of Exploration Geochemists

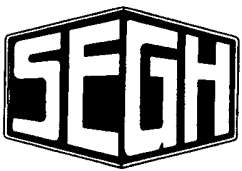

Society for Environmental Geochemisty and Health

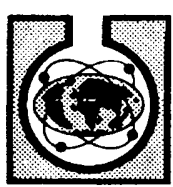

International Association of Geochemistry and Cosmochemistry 


\section{TABLE OF CONTENTS}

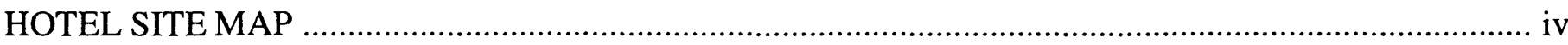

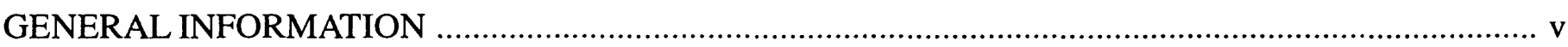

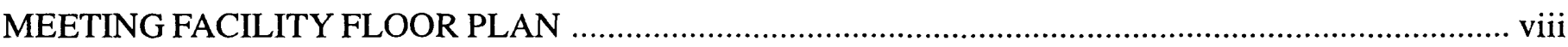

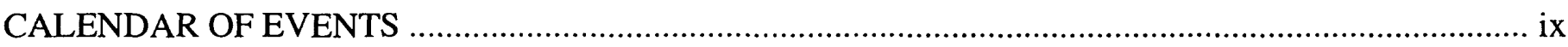

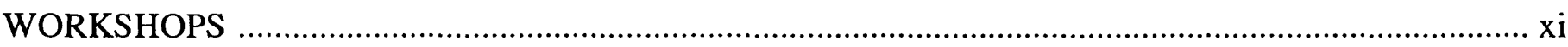

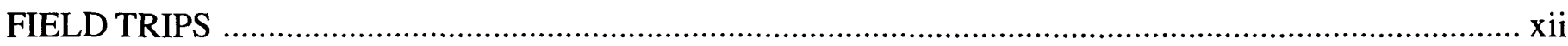

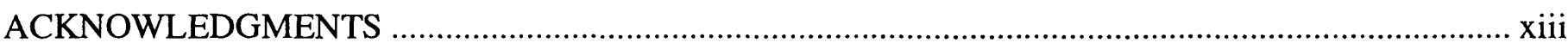

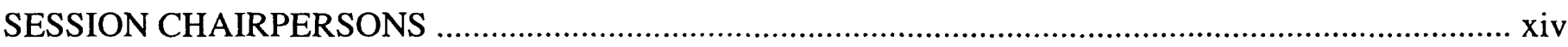

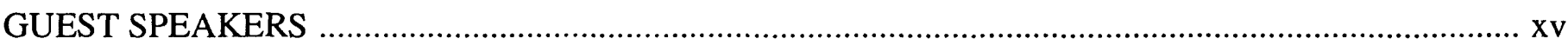

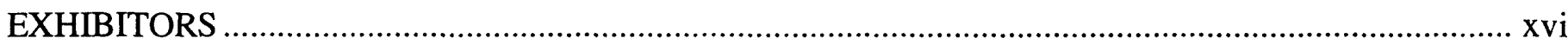

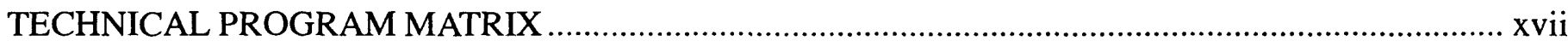

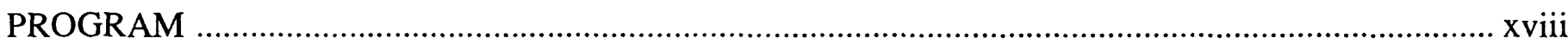

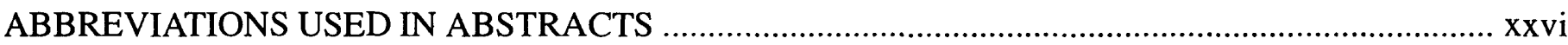

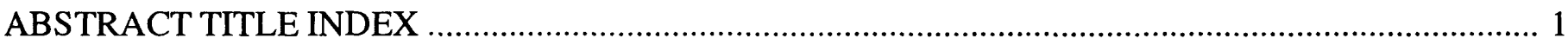

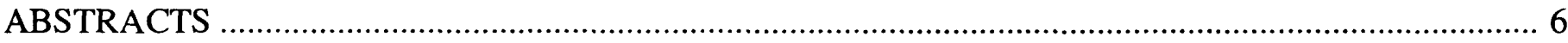

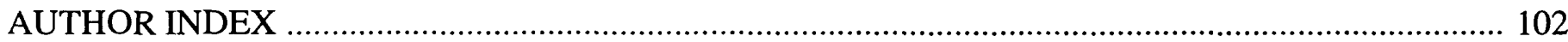

\section{4th International Symposium on Environmental Geochemistry}

\section{ORGANIZING COMMITTEE}

\author{
Ms. Cathy Ager \\ Dr. James Crock \\ Mr. David Detra \\ Dr. Larry Gough \\ Ms. Susan Kropschot \\ Ms. Pat Krupa
}

\author{
Dr. Paul Lamothe \\ Mr. Sherman Marsh \\ Ms. Coleen Schmitt \\ Mr. Richard Sanzolone \\ Dr. Ronald Severson \\ Dr. David Smith
}

\section{SCIENTIFIC COMMITTEE}

Dr. Willard Chappell

Dr. Brian Davies

Dr. Ron Fuge

Dr. Robert Garrett

Dr. Gwennyth Hall
Dr. Betsy Kagey
Dr. Donald Runnells
Dr. Olle Selinus
Dr. Iain Thornton
Dr. Richard Wanty 


\section{SITE MAP}

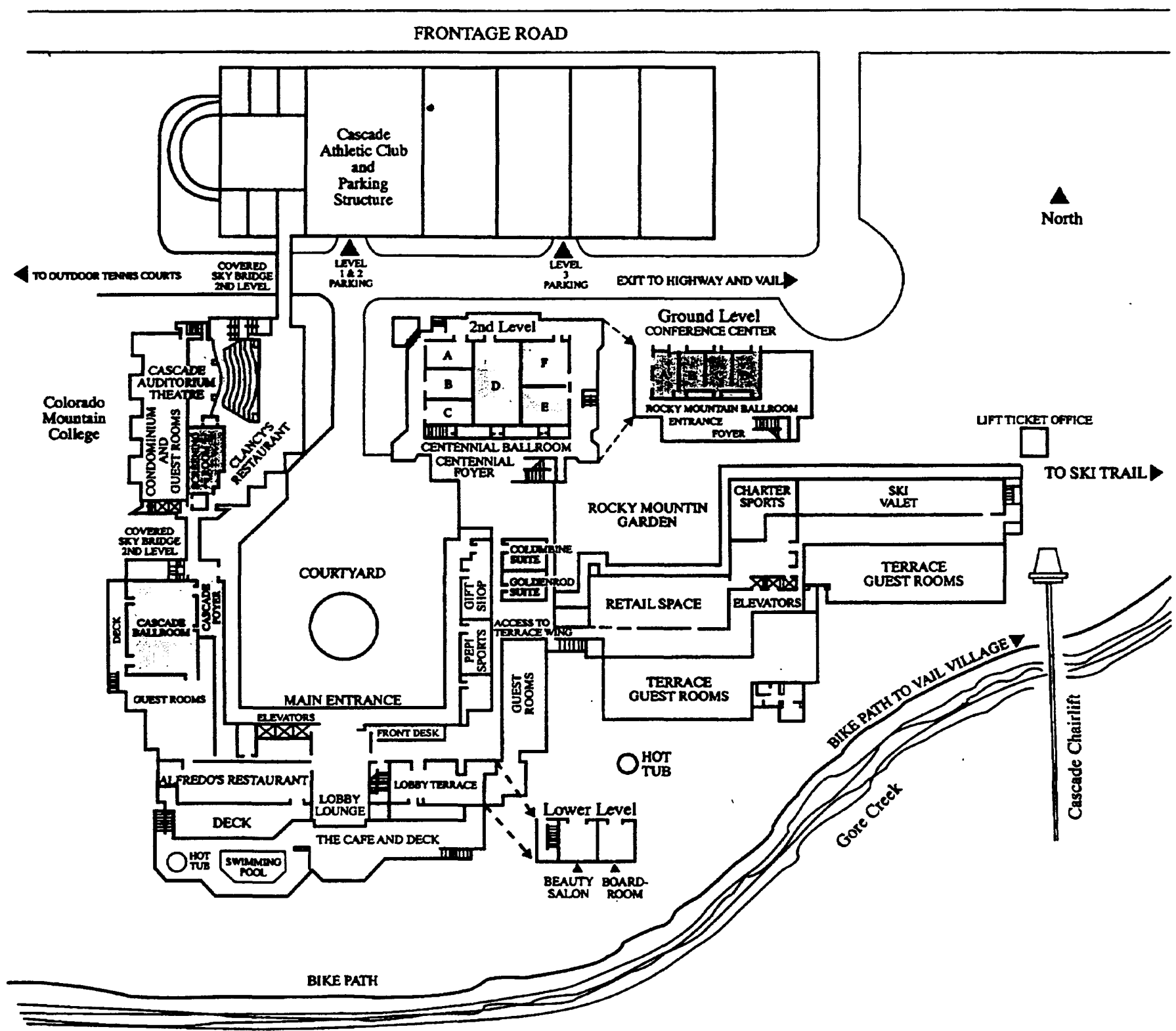




\title{
4th International Symposium on Environmental Geochemistry Conference
}

\author{
October 5 - October 10, 1997 \\ Vail Cascade Hotel \& Club \\ Vail, Colorado
}

\section{GENERAL INFORMATION}

ACCOUNTS - All incidental expenses for items not covered by your registration fee are your responsibility and must be settled directly between you and the Hotel. These expenses include items such as: meals, telephone calls, room service, bar bill, additional accommodations, golf green fees, etc.

ACUTE MOUNTAIN SICKNESS—Please take the time to read the Colorado Altitude Research Institute information included in your registration bag. Vail Valley starts at 8,000-foot $(2500-\mathrm{m})$ elevation, with surrounding terrain rising higher. Depending upon the altitude, 20 to $30 \%$ of all visitors from sea level have one or more symptoms of acute mountain sickness. The Organizing Committee would like your stay to be safe and enjoyable.

$\checkmark$ Increase Fluid Intake

$\checkmark$ Decrease Salt Intake

$\checkmark$ Moderate Your Physical Activity

$\checkmark$ Eat Low Fat Meals

$\checkmark$ Reduce Alcohol and Caffeine Consumption

$\checkmark$ Feeling Lousy? Seek Help through Hotel

$\checkmark$ Have Fun!

CASCADE ATHLETIC CLUB-For a nominal daily usage fee of $\$ 12.00$ (\$20/4 days, $\$ 30 /$ week), delegates have privileges to the sports, fitness, and health facility. Located adjacent to the Hotel, the Club provides a variety of spa and recreation facilities including indoor/outdoor tennis, racquetball, squash, basketball, aerobics, Nautilus equipment, steam rooms, and more. Passes can be purchased at the front desk.

HOTEL CHECK-IN AND CHECK-OUT TIME-Hotel check-in time is 4:00 p.m. on day of arrival and check-out time is 12:00 p.m. on day of departure or Friday, October 10. Luggage may be stored at the front desk. Delegates staying in their rooms beyond check-out time will be charged for an additional room night.

MESSAGE CENTER - A message center will be maintained in the Centennial Foyer for the convenience of conference attendees. Incoming messages for attendees will be posted on individual room phones or the message center board, near the Registration Desk. To call the center, dial 970-476-7111 and ask for the 4th ISEG Message Center.

NO SMOKING -For the comfort of all, please refrain from smoking in the meeting rooms, eating areas, and foyer.

BUSINESS CENTER—Fax, photocopying, or transparencies. Check at Hotel Registration Desk.

EXHIBITS - The 4th International Symposium on Environmental Geochemistry will feature an exhibition of scientific equipment, accessories, and supplies. Exhibits will be located in the Centennial Foyer. Exhibits will be open Monday, Tuesday, Thursday, and Friday during conference hours with coffee and soft drinks served each day during breaks.

$\begin{array}{lll}\text { EXHIBIT HOURS: } & \text { Monday, October } 5 & 9 \text { a.m. to } 8 \text { p.m. } \\ & \text { Tuesday, October } 7 & 9 \text { a.m. }-5 \text { p.m. } \\ & \text { Thursday, October } 9 & 9 \text { a.m. }-6: 30 \text { p.m. } \\ & \text { Friday, October } 10 & 9 \text { a.m. }-12 \text { noon }\end{array}$

ORAL PRESENTATIONS - The Conference Center Centennial Ballroom will be the site for all lectures.

Because of the parallel sessions, Session Chairs have been asked to keep strictly to the schedule time table, which allows 20 minutes for presentations. Authors are requested to make themselves known to the Session Chairs before the session begins.

Speakers will be able to preview their slides in the Goldenrod Suite. Viewers will be available. 
POSTER PRESENTATIONS-Posters will be on display in the Rocky Mountain Ballroom Sunday evenings through Friday morning. Authors will be asked to attend their posters during the Monday mixer and Thursday social hour. Session 1, 3, 5, 7, 8 , and 10 authors may put up their posters between 3:00 and 5:30 p.m. on Sunday and should take them down before noon on Wednesday to ensure that the boards are available. Session 2, 4, 6, and 9 authors may put up their posters Wednesday afternoon and should take them down by 1:00 p.m. on Friday.

REGISTRATION-Registration Badges are required for admission to all technical sessions, exhibits, and functions. The appropriate badge is required for admittance and will be checked at the entrances of all activities. Everyone attending the Conference, including speakers and exhibitors, is required to register. Advance registration pickup and on-site registration will be conducted during the following hours:

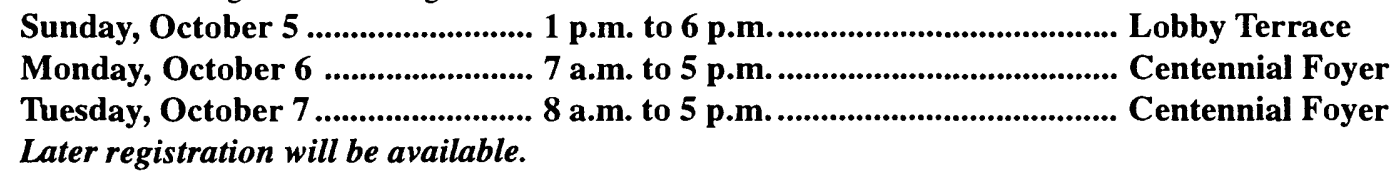

REGISTRATION FEE-The registration fee is $\$ 325$. This includes the published program with abstracts, refreshments breaks, opening reception on Sunday, October 5, and banquet on Thursday, October 9, and all other social functions. One-day passes will be available for attendance at the presentation sessions and refreshments breaks for $\$ 150$ per day. Students may register for $\$ 100$ with a valid student card (excludes banquet); spouses for $\$ 100$ (social functions including banquet).

SESSION CHAIRS-Please meet briefly with the Organizing Committee on Monday, October 6 at 12 noon in Centennial $\mathrm{ABCD}$.

SHUTTLE BUS - The Hotel operates a complimentary shuttle from 7 a.m.-12 midnight to Vail Village and LionsHead for general guest use. Shuttles operate on 20-minute intervals, depending on distance and weather conditions. Van transportation from the Hotel to Denver International Airport is available from Colorado Mountain Express at Tel: 1-800-525-6363. When making your reservation, mention the special group code " 4 th ISEG" and receive a discount.

\section{SOCIAL FUNCTIONS}

Opening Reception-Sunday, October 6, from 6:00-8:00 p.m. in the Cascade Ballroom.

Mixer (in conjunction with Posters)-Monday, October 7, from 5:30-7:00 p.m. in the Centennial Foyer.

Social Hour (in conjunction with Posters)—Thursday, October 9, from 5:30-6:30 p.m. in the Centennial Foyer.

Banquet-Thursday, October 9, from 6:30-8:30 p.m. in the Cascade Ballroom.

Please notify the Organizing Committee by Monday evening if you have any special food requirements for the banquet.

A presentation for guests on Vail Valley activities will be given by the Hotel concierge in the Lobby Terrace from 9:00-10:00 a.m., Monday, October 6. Recreation information will be available at the Conference Registration Desk Monday during the lunch break and during the mixer. 
FOOD SERVICE - Breakfast will be available between 6:30 and 8:00 a.m. in the Cascade Ballroom every morning. Lunch will be served from 12:00 noon to 1:40 p.m. in the Cascade Ballroom. Refreshments will be served during the morning and afternoon breaks in the Centennial Foyer, where the exhibits will be displayed.

MENU-(All prices include tax and gratuity)

\section{Breakfast options October 6-10}

A la Carte Quick breakfast

Coffee

Juice

Bagel

Muffin, Danish, Doughnut $\$ 2.00$

Full Continental breakfast $\$ 11.00$

Coffee, juice, fresh fruit, cold cereals, breakfast breads, Danish, muffins, toast, hard breads, and international and domestic cheeses.

Full Buffet Breakfast $\$ 13.00$

includes all of the above plus fluffy scrambled eggs, Colorado hash browns, sugar cured bacon or country sausage, and a daily griddle item.

\section{Lunch option Monday, October 6}

Italian Pasta Buffet $\$ 13.00$

Two pastas, tomato basil and alfredo sauce, Caesar salad, garlic bread, Chef's choice of Italian dessert, and iced tea.

\section{Lunch option Tuesday, October 7}

Executive Deli Buffet $\$ 13.00$

Assorted cold cuts, soup du jour, assorted cold salads, appropriate condiments, tossed salad with two dressings, breads, brownies, and iced tea.

\section{Lunch option Thursday, October 9}

Mountain Grill Buffet

Grilled hamburgers and hot dogs, corn on the cob, cowboy beans, tossed salad, fresh lettuce and tomato, appropriate condiments, fruit cobbler, and iced tea.

\section{Lunch option Friday, October 10}

Mexican Madness Buffet $\$ 13.00$

"Build-your-own-taco-station" with flour and corn tortillas, ground beef, shredded cheese, diced fresh tomatoes, onions, peppers, sour cream, guacamole, etc., tossed salad, sugared churros, and iced tea. 


\section{MEETING AND BANQUET FACILITIES}

\section{CONFERENCE CENTER}

\section{ROCKY MOUNTAIN BALLROOM}

First Level

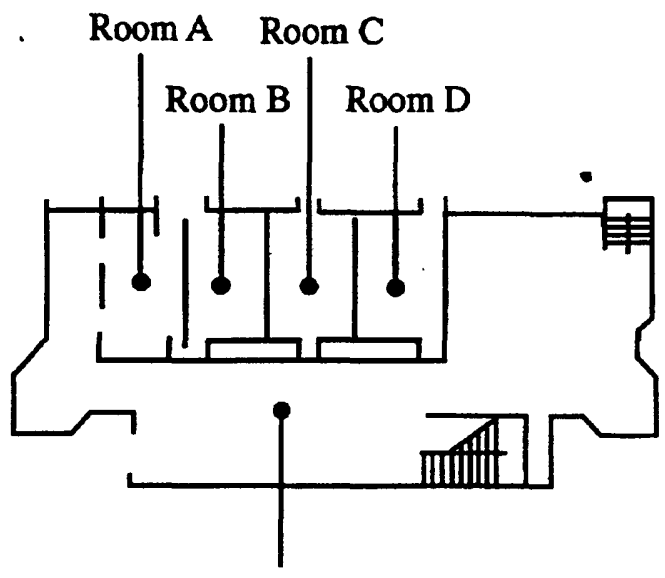

Rocky Mountain Foyer

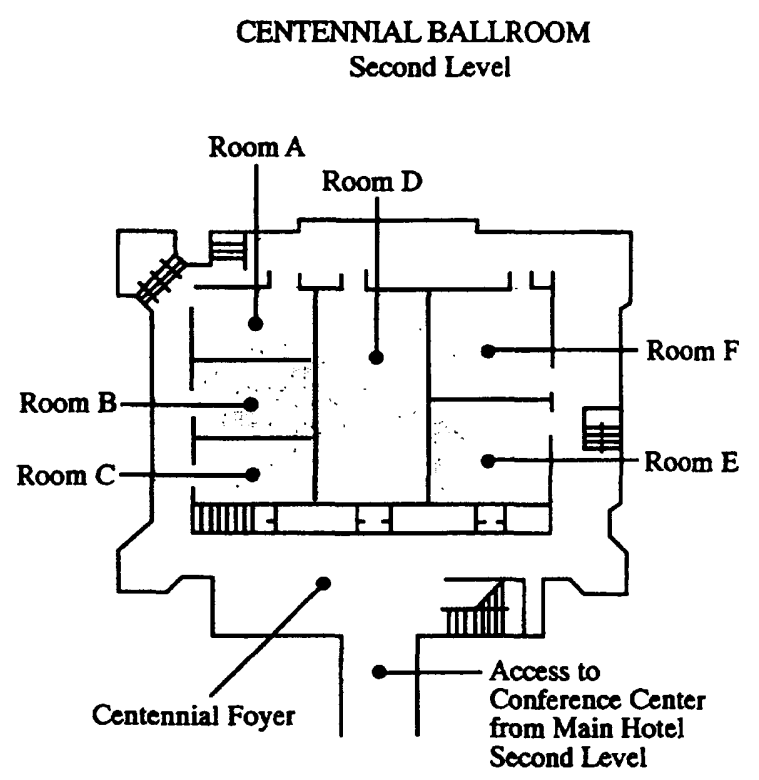

MAIN HOTEL

CASCADE BALLROOM

First Level

THEATERS

Second Level

MEETING SUITES

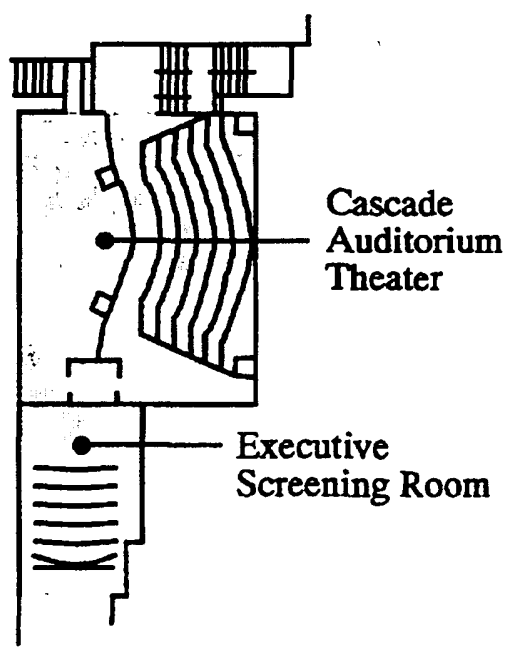

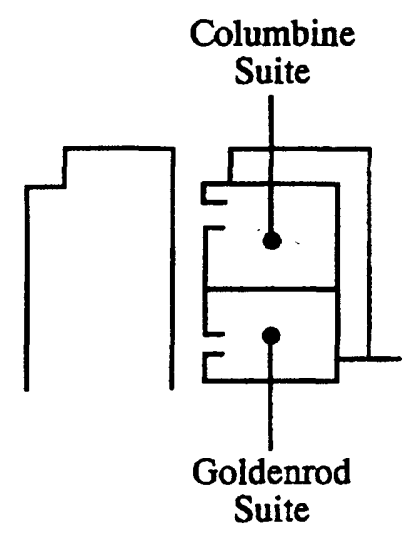




\section{CALENDAR OF EVENTS}

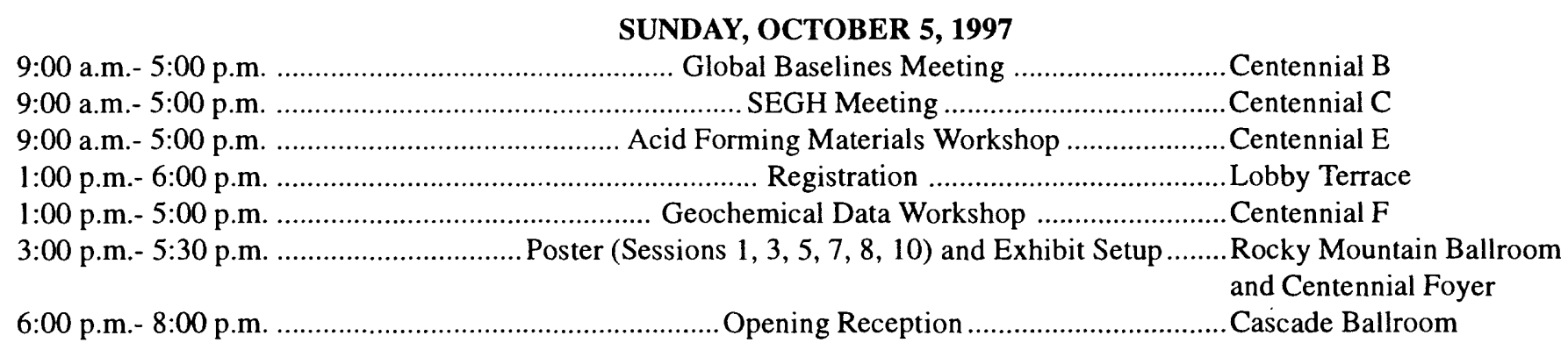

MONDAY, OCTOBER 6, 1997

6:30 a.m.- 8:00 a.m. Breakfast on your own .Cascade Ballroom 7:00 a.m.- 5:00 p.m. 7:00 a.m.- 5:00 p.m. Conference Registration 8:00 a.m.- 8:00 p.m. Speaker Ready Room Centennial Foyer 8:20 a.m.-10:00 a.m. Poster Session $(1,3,5,7,8,10)$ General Session Goldenrod 9:00 a.m.-10:00 a.m. 9:00 a.m.- 8:00 p.m. 10:00 a.m.-10:20 a.m. 10:20 a.m.- $12: 00$ noon 10:20 a.m.-12:00 noon 12:00 noon- 1:40 p.m. 12:00 noon- 1:40 p.m. 12:00 noon Vail Valley activity presentation Rocky Mountain Ballroom Centennial ABCD ................. Exhibits Refreshment Break Lobby Terrace .Centennial Foyer Session 1-1 to 1-4 Centennial Foyer Centennial ABCD Session 2-1 to 2-4 Centennial EF Lunch on your own Cascade Ballroom Tourist Information-Reg. Desk Registration Desk Chairperson meeting 1:40 p.m.- 3:20 p.m 1:40 p.m.- 3:20 p.m. Session 1-5 to 1-9 Session 2-5 to 2-9 3:20 p.m.- 3:40 p.m. Refreshment Break 3:40 p.m.- 5:10 p.m. 3:40 p.m.- 5:10 p.m. 5:30 p.m.- 7:00 p.m. Session 1-10 to 1-13 Session 2-10 to 2-13 Mixer Tourist Information . Centennial ABCD Centennial ABCD Centennial EF Centennial Foyer Centennial ABCD Centennial EF Centennial Foyer 5:00 p.m.- 6:30 p.m.

TUESDAY, OCTOBER 7, 1997

6:30 a.m.- 8:00 a.m 7:00 a.m.- 5:00 p.m. 8:00 a.m.- 5:00 p.m. 8:00 a.m. $-10: 00$ a.m. 8:00 a.m.-10:00 a.m. 8:00 a.m.- 5:30 p.m. 9:00 a.m.- 5:00 p.m. 10:00 a.m. $-10: 20$ a.m. 10:20 a.m.-12:00 noon 10:20 a.m.-12:00 noon 12:00 noon- 1:40 p.m. 1:40 p.m.- 3:20 p.m. 1:40 p.m.- 3:20 p.m. 3:20 p.m.- 3:40 p.m. 3:40 p.m.- 5:10 p.m. 3:40 p.m.- 5:10 p.m. 5:30 p.m.- 7:00 p.m.
Breakfast on your own Speaker Ready Room Registration

Session 3-1 to 3-6

Session 4-1 to 4-6

Poster Session $(1,3,5,7,8,10)$

Exhibits

Refreshment Break.

Session 3-7 to 3-10

Session 4-7 to 4-10

Lunch on your own

Session 3-11 to 3-15

Session 4-11 to 4-15

Refreshment Break

Session 3-16 to 3-19

Session 4-16 to 4-19

SEGH Business Meeting
Cascade Ballroom

.Goldenrod

Centennial Foyer

..Centennial ABC

Centennial D

. Rocky Mountain Ballroom

Centennial Foyer

Centennial Foyer

.Centennial ABC

Centennial D

Cascade Ballroom

Centennial ABC

Centennial D

Centennial Foyer

Centennial ABC

Centennial D

Centennial E 
WEDNESDAY, OCTOBER 8, 1997

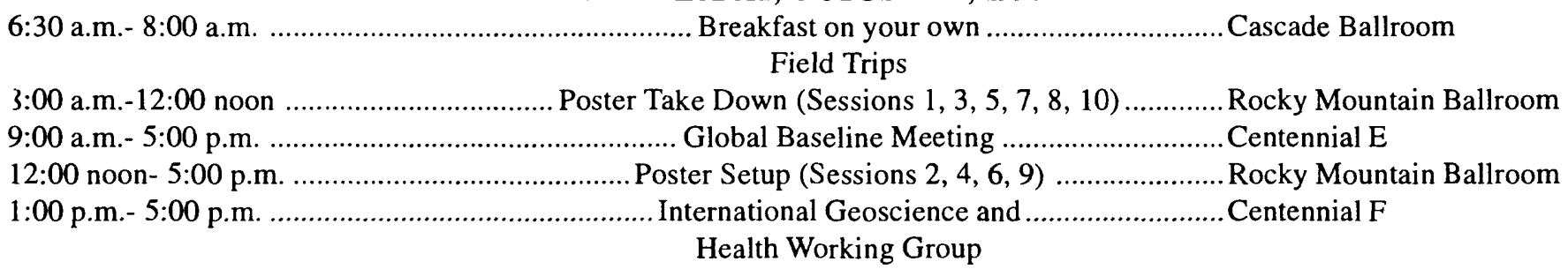

\section{THURSDAY, OCTOBER 9, 1997}

6:30 a.m.- 8:00 a.m.
7:00 a.m.- 2:00 p.m.
8:00 a.m.- 5:30 p.m.
8:00 a.m.-10:00 a.m.
8:00 a.m.-10:00 a.m.
9:00 a.m.- 6:30 p.m.
10:00 a.m.- $10: 20$ a.m
10:20 a.m.-12:00 noo
10:20 a.m.-12:00 noo
12:00 noon- 1:40 p.m
1:40 p.m.- 3:20 p.m.
1:40 p.m.- 3:20 p.m.
3:20 p.m.- 3:40 p.m.
3:40 p.m.- 5:10 p.m.
3:40 p.m.- 5:10 p.m.
5:30 p.m.- 6:30 p.m.
5:30 p.m.- 6:30 p.m.
6:30 p.m.- 8:30 p.m.

Breakfast on your own Speaker Ready Room

Poster Session $(2,4,6,9)$ Session 5-1 to 5-6

Session 4-20 to 4-25

Cascade Ballroom

Goldenrod

Rocky Mountain Ballroom

Exhibits

Centennial ABC

Centennial D

Refreshment Break

Session 6-1 to 6-4

Session 8-1 to 8-4

Lunch on your own

Session 6-5 tp 6-9

Session 8-5 to 8-9

Refreshment Break.

Session 6-10 to 6-13

Session 8-10 to 8-13

Centennial Foyer

Centennial Foyer

Centennial ABC

Centennial D

Cascade Ballroom

Centennial ABC

Centennial D

Centennial Foyer

Centennial ABC

AEG Business Meeting

Social Hour

Centennial D

Cascade Ballroom

Banquet

Rocky Mountain Foyer

Centennial Ballroom

FRIDAY, OCTOBER 10, 1997

6:30 a.m.- 8:00 a.m

7:00 a.m.- 2:00 p.m.

8:00 a.m.-10:00 a.m.

8:00 a.m.-10:00 a.m.

8:00 a.m. $-10: 00$ a.m.

8:00 a.m.- 5:30 p.m.

9:00 a.m.- 12:00 noon

10:00 a.m.-10:20 a.m.

10:20 a.m.-12:00 noon

10:20 a.m.-12:00 noon

12:00 noon-12:30 p.m.

12:30 p.m.
Breakfast on your own

Speaker Ready Room

AEG Council Meeting

Session 5-7 to 5-12

Session 7-1 to 7-6

Poster Session \& Take Down $(2,4,6,9)$.

Exhibits

Refreshment Break

Session 9-1 to 9-5

Session $10-1$ to $10-4$

Closing General Session

Lunch on your own
Cascade Ballroom

Goldenrod

Lobby Terrace

Centennial ABC

Centennial D

Rocky Mountain Ballroom

Centennial Foyer

Main Centennial Foyer

Centennial ABC

Centennial D

Centennial ABCD

Cascade Ballroom 


\section{WORKSHOPS-SUNDAY, OCTOBER 5}

Acid-Forming Materials and Land Reclamation 9:00 a.m. - 5: 00 p.m.
Scott Fisher

River Bend Assoc.
Centennial E

Fee: $\$ 75$

The workshop will provide the participant with an overview of the importance and types of pre-disturbance planning procedures. It will discuss methods of mitigation of acid forming materials (AFM) resulting from mining and related forms of drasticland disturbance. Emphasis during the program will be placed on the identification of AFM and its proper handling during the mining operation. Integration of mining procedures with reclamation plans will be stressed. The limited potential for ecosystem reclamation where AFM contamination has taken place is an important thesis that will be stressed throughout the program.

Elements of the course will include a broad introduction, a discussion of pyrite and related mineral formation, processes associated with the weathering of pyrite, impact of acid plant growth media on land reclamation, and acid mine drainage. In addition, topics to be discussed include the sampling and analytical characterization of earthen materials potentially containing AFM, mitigation of terrestrial and aquatic impacts from AFM oxidation, and a review of several case studies involving AFM in the western United States.

Workshop leaders and their topical areas of expertise include: Dr. Terry Brown, Western Research Institute , Laramie, WY (analytical, mitigation, agronomy, and case studies); Margaret Condron, formerly with the Office of Surface Mining, Denver, CO (analytical, planning, agronomy); Scott Fisher, River Bend Associates and Arid Lands Reclamation Newletter, Medicine Bow, WY (planning, analytical, mitigation).

Collecting geochemical data for both exploration and environmental purposes 1:00 p.m. - 5: 00 p.m.

\author{
Richard K. Glanzman \\ CH2M Hill, \\ L. Graham Gloss, \\ Colorado School of Mines \\ and \\ Jeff Jaacks \\ BHP Minerals
}

Centennial E Fee: $\$ 50$

Data collected and analyzed for exploration purposes can be even more cost-effective and useful when it is used for environmental purposes. The seminar provides exploration and environmental professionals with the information to acquire more useful data for both purposes and to fulfill regulatory agency requirements. A few relatively minor changes can make exploration data not only more accurate and precise, it can also make the same data useful for environmental purposes. This approach can be used during reconnaissance but is intended for use on properties under serious exploration scrutiny.

Topics addressed in this four hour seminar include: definition of sampling objectives, orientation/background surveys, methods of efficiently collecting appropriate data of various media, sampling representativeness, background/baseline issues, analytical considerations/requirements, commercial standards versus site-specific standards (preparation/usefulness), statistical analysis, and risk/liability considerations. Exploration case histories illustrate the usefulness and advantages of this approach.

Decisions made based on the exploration data can be significantly improved. However, of considerably greater importance, the data can significantly reduce the cost and improve the effectiveness of environmental considerations. These considerations involve not only future environmental evaluation(s) but also provide data to support more effective design/evaluation of mine waste disposal to control and minimize environmental concerns. 


\section{FIELD TRIPS \\ David B. Smith, Coordinator}

All trips start and end at the Vail Cascade Hotel \& Club. Departure times will be announced and posted. If you have not pre-registered for a trip, on-site registration may be possible; check at the Registration Area, Vail Cascade Hotel \& Club. All participants will be accepted on a first-come, first-served basis.

\section{Clear Creek Watershed-Wednesday, October 8}

Clear Creek extends from the Continental Divide near the Loveland Ski Area to the confluence with the South Platte River in metro Denver. Waters in Clear Creek are impacted by abandoned mines and dumps within the Colorado Mineral Belt and by industrial and municipal wastewater, stormwater and sewer overflows, and accidental leaks and spills of toxic substances. To deal with these pollution issues, Clear Creek has a nationally recognized, award-winning watershed initiative underway. The field trip will capture both the substance of the initiative as well as the spirit of the effort. Major sources of pollution such as mine drainages and tailings piles will be visited as well as major cleanup sites using both active and passive treatment facilities. The fee is $\$ 70$, which includes a box lunch.

\section{Leadville, Colorado-Wednesday, October 8}

The historic mining town of Leadville sits near one of the world's largest polymetallic replacement deposits. Since the discovery of gold in 1858 , more than $\$ 5.4$ billion (1989 prices) of gold, silver, lead, and zinc have been extracted from ores in the Leadville mining district. This large-scale mining also extracted its toll on the environment. In 1983, the town was declared an 18-square-mile (46.6-square kilometer) Superfund site by the U.S. Environmental Protection Agency as a result of concerns for impacts to water quality and human health due to heavy metal contamination. This field trip will explore the mining history and current remedial activities in and around Leadville. The fee is $\$ 55$, which includes a box lunch.

\section{Eagle Mine-Wednesday, October 8}

The Eagle Mine is an inactive mining and milling facility located on the Eagle River between the towns of Redcliff and Minturn. Silver-lead and gold-silver ores attracted miners to the area in the late 1870's. Lead-zinc sulfide ore was encountered in the 1890's with mining of zinc ore continuing until the early 1980's. The environmental impact of more than 100 years of mining and milling operations on the Eagle River and adjacent areas was very evident and caused the U.S. Environmental ?rotection Agency to place the site on its Superfund list in 1986. Since that time a remedial action plan has provided for flooding of the mine workings, consolidation of eight tailings piles into one, placement of a multi-layer clean soil cap over the remaining consolidated pile, and construction of a water treatment plant. This field trip will provide an overview of the abandoned mine site, its environmental and public health impacts, and the ongoing remedial actions. The fee is $\$ 35$. Anticipated duration is about 3 hours-no lunch will be provided.

\section{Climax Molybdenum Mine-Wednesday, October 8}

The Climax Mine is the world's largest molybdenum mine and rests atop the Continental Divide at an altitude of $11,300 \mathrm{ft}$. $(3,440 \mathrm{~m})$. At the headwaters of three drainages, the Eagle and Arkansas Rivers and Tenmile Creek, Climax was staked in the late 1800's for gold before uses of molybdenum had been developed. Gold was never recovered at the Climax Mine, but production of molybdenum began in 1918. The mine is currently not in production, but a small staff is conducting care and maintenance with reclamation and water management being major activities. Capping of tailing impoundments, water development, and revegetation activities take place in the short construction season afforded by this extreme climate. Climax receives an average of $260 \mathrm{in}$. $(660 \mathrm{~cm}$.) of snow annually and manages water discharges in excess of 200 million gallons (757,000 cubic meters) per day. This field trip will provide the opportunity to learn about the history, geologic setting, and current environmental activities at the mine. The fee is $\$ 55$, which includes a box lunch.

\section{Upper Animas Watershed-Friday through Sunday, October 10-12}

The Upper Animas Watershed, in the heart of the rugged San Juan Mountains of southwest Colorado, has been seriously impacted from metals in sediments and surface waters. The upper basin was heavily mined for gold, silver, and base metals over the past 120 years and thousands of inactive mine sites remain. The Animas River Stakeholders Group has developed a collaborative process (involving local, State, and Federal agencies, mine corporations, land owners, and citizens) for characterizing the sources of metals-related contamination throughout the watershed. The inactive mine sites are being characterized, evaluated for remediation potential, and prioritized for cleanup. The field trip will focus on the Silverton area, the last remaining mine town in San Juan country. Sites will be visited that demonstrate the extent of the existing problems as well as those that reflect pre-

rining conditions. Presentations will be given on the history, geology, and ecology of the basin and the numerous geochemical, biological, and physical habitat studies underway. A number of sites that are undergoing remediation will be viewed. The fee is $\$ 310$, which includes 3 lunches and 2 nights lodging — double occupancy. 


\section{ACKNOWLEDGMENTS}

\section{Sponsorship}

The Organizing Committee would like to express their gratitude to the following companies, organizations, and professional societies for their generous support of the 4th International Symposium on Environmental Geochemistry.

The United States Geological Survey (USGS) is the leading earth-science organization in the United States. Its mission, since its creation in 1879 , has been to investigate, analyze, and disseminate earth-science information needed to solve geological and environmental problems, and to identify and assess resources. The USGS has a long tradition of providing accurate and impartial information to all customers. The USGS conducts investigations and research in geology, geophysics, hydrology, mapping, remote sensing, environmental hazards, environmental issues, and related disciplines. The USGS also conducts mineral and energy resource assessment studies.

The Association of Exploration Geochemists (AEG) was founded in 1970 to provide an international forum for persons working in the field of applied geochemistry. It is a professional, non-profit organization promoting interest in the application of geochemistry to mineral and petroleum exploration, resource evaluation, environmental issues, and related fields around the world. The AEG encourages membership and/or contributions from individuals or organizations working with or providing geochemical data for a variety of uses including mineral exploration, analytical technology, computer processing, environmental issues, agriculture, geobotany, biochemistry, and other applications. The AEG disseminates timely information on geochemistry through its journal, the Journal of Geochemical Exploration and through its quarterly newsletter, EXPLORE.

The Society for Environmental Geochemistry and Health (SEGH) was founded in 1972 to provide a forum for scientists from various disciplines (geology, biology, epidemiology, medicine, risk assessment, ecology, etc.) to study the relationship between the geochemical environment and health and disease in plants, humans and animals. SEGH recognizes the importance of this approach in opening the lines of communication between academia, industry and regulatory agencies. SEGH, through annual conferences, our journal Environmental Geochemistry and Health, and Task Forces, provides our membership the opportunity to address environmental geochemistry and health issues from their representative disciplines and, at times, conflicting points of view.

The International Association of Geochemistry and Cosmochemistry (IAGC) is affiliated with the International Union of Geological Sciences and has been one of the preeminent international geochemical and cosmochemical organizations for over twenty-five years. The principal objective is to foster cooperation in, and advancement of, geochemistry and cosmochemistry in the broadest sense. This is achieved (1) by working with any interested group in planning symposia and other types of meetings related to geochemistry and cosmochemistry; (2) by sponsoring publications in geochemistry and cosmochemistry of a type not normally covered by existing organizations; and (3) through the activities of working groups which study problems that require, or would benefit from, international cooperation.

The scientific thrust of IAGC takes place through its Working Groups (many of which organize regular symposia) and the official journal APPLIED GEOCHEMISTRY. The interests of the Working Groups cover a wide spectrum of geochemical and cosmochemical activities, including (1) geochemical prospecting; (2) water-rock interaction; (3) interaction between water and living matter; (4) extraterrestrial geochemistry; (5) geochemistry of the earth surface; (6) geochemistry of isotopes; (7) thermodynamics of natural processes; (8) cooperation in applied geochemistry-special training for the developing countries; (9) geochemistry of health and disease. Although partial financial support for the Working Groups comes from IAGC, most are self-sustaining. Participants in the Working Groups may include geochemists who are not Individual Members of IAGC. 


\section{Session Chairpersons}

The 4th ISEG Organizing Committee thanks the session chairs named below for their contribution:

Session 1: $\quad$ Mine Drainage Formation and Geochemistry-

Kathleen Smith, Jenny Webster, Donald Runnells, and Willard Chappell

Session 2: $\quad$ Geochemistry of Fresh Water \& Marine Environments-

Frank Manheim, Edeltrauda Helios-Rybicka, Joy Rae, and Martin Fey

Session 3: $\quad$ SEGH-Sponsored Session-Environmental Geochemistry and Health

Betsy Kagey, Iain Thornton, Brian Davies, and Ron Fuge

Session 4: $\quad$ Methods of Environmental Geochemical Monitoring, Modeling, and Mapping and Use and Determination of Geochemical Baselines

Olle Selinus, Alina Kabata-Pendias, Jörg Matschullat, and Dave Smith

Session 5: $\quad$ Trace Substances, Ecosystems, and Bioavailability-Aquatic/Atmosphere

Laurie Balistrieri, David Levy, John Gray, and Gianni Cortecci

Session 6: $\quad$ AGE-Sponsored Session-Environmental Geochemistry of Ore Deposits

Sherman Marsh, Eion Cameron, Robert Garrett, and Maurice Chaffee

Session 7: $\quad$ Environmental Analytical Techniques \& Applications

Gwennyth Hall and James Crock

Session 8: $\quad$ Trace Substances, Ecosystems, and Bioavailability-Terrestrial

William Orem, Irina Stangeeva, Harald Püchelt, and Rama Kotra

Session 9: $\quad$ Remediation of Mining-Related Disturbances

Harry Posey and Suresh Kumar

Session 10: $\quad$ Natural and Man-Made Radiogenic Hazards

Rich Wanty and John Glendinning 


\section{GUEST SPEAKERS}

P. Patrick Leahy, Chief Geologist

U.S. Geological Survey

Reston, Virginia

Dr. P. Patrick Leahy was named Chief Geologist of the Geologic Division of the U.S. Geological Survey in 1995. He has been with the U.S. Geological Survey since 1974, having served in various technical and managerial positions, including Chief of the National Water-Quality Assessment Program.

Dr. Leahy was born in Troy, New York, in 1947. He holds undergraduate and graduate degrees in geology (1968) and geophysics (1970) from Boston College. He received his doctorate in geology (1979) from Rensselaer Polytechnic Institute where he specialized in regional ground water studies and hydraulics.

Dr. Leahy is a Fellow in the Geological Society of America and is a member of the American Geophysical Union and the American Institute of Hydrology. He has received many awards and is active in numerous professional organizations. Currently he is President of the International Association of Hydrogeologists.

\section{Linda C. Gundersen}

U.S. Geological Survey

Mineral Resources Program

Reston, Virginia

For the last 18 years, Linda Gundersen has worked as a geologist with the US Geological Survey. She is Coordinator of the Mineral Resources Program which is a $\$ 58$ million domestic program with a staff of 440 people and a $\$ 12$ million international mission in Saudi Arabia. She started with the USGS as a field assistant working on diverse projects in sedimentology, stratigraphy, and economic geology. She spent 12 years conducting research and heading projects in the field of radionuclides-from determining the origin of hard rock uranium deposits to studying radon, uranium, and radium in soil, rocks, and water, and eventually assessing the geologic radon potential of the United States. In 1995, she took a temporary assignment as Coordinator of the Energy Program and in 1996 became the Coordinator of the Minerals Program-overseeing a major reorganization. Currently she also serves on a National Academy of Sciences Committee on Risk Assessment of Exposure to Radon in Drinking Water and on the Steering Committee of the IUGS-UNESCO Deposit Modeling Program. Her academic background includes undergraduate and graduate work in structural geology and geochemistry at the State University of New York at Stony Brook and at the University of Colorado in Boulder.

\section{Alina Kabata-Pendias \\ Trace Element Laboratory \\ Pulawy, Poland}

Professor Kabata-Pendias is Professor of Soil Chemistry and head of the Trace Element Laboratory of the Institute of Soil Science and Plant Cultivation in Pulawy, Poland, where she has worked for over 30 years. She is an author of more than a hundred publications on the occurrence of trace elements in natural and contaminated environments including the much-acclaimed book "Trace Elements in Soils and Plants" (CRC Press). Professor Kabata-Pendias also works in the Geological Institute in Warsaw on the mobility of trace elements and on the alteration of minerals in weathered zones of various geological formations. She has been involved in analytical and methodological studies on trace elements and clay minerals. Dr. KabataPendias continues to be very active in numerous scientific societies as both councilor and committee member.

\section{Thomas J. Noel}

Banquet Speaker

University of Colorado at Denver

Denver, $\mathrm{CO}$

Dr. Noel is a professor of history at the University of Colorado, Denver who specializes in Colorado history. He has authored over 60 publications including articles, books, reviews, and television scripts. He has won numerous awards for both his writing and his teaching. He is a recognized expert on the mining camps and "Old West" flavor of Colorado. He is active in many professional associations many of which are dedicated to the preservation of the architecture and culture of historical Colorado. 


\section{EXHIBITORS \\ Paul Lamothe, Coordinator}

The 4th International Symposium on Environmental Geochemistry thanks vendors for providing an opportunity to see and discuss their products and services. The following exhibitors will be in attendance:

5th ISEG

ACZ Laboratories, Inc.

Canadian Certified Reference

Materials Project

Crystals Unlimited

Quanterra Enviromental Services, Inc.

Shepherd Miller, Inc.

U.S. Geological Survey
University of Cape Town

Department of Geological Sciences

Rondebosch, South Africa 7700

30400 Downhill Drive

Steamboat Springs, CO 80487

(800) 334-5493

555 Booth Street

Ottawa, Ontario, Canada

K1A 0G1

(613) 992-1055

P.O. Box 5054

Golden, CO 80401

(303) 278-1218

4955 Yarrow Street

Arvada, CO 80002

(303) 421-6611

3801 Automation Way

Fort Collins, CO 80525

(970) 223-9600

Mineral Resources Program

12201 Sunrise Valley Dr., MS-913

Reston, VA 20192

(703) 648-6620

P.O. Box 26099

72 Robertson Road

Nepean, ON K2H 9R0

Canada 


\section{4th International Symposium on Environmental Geochemistry Program Matrix}

Senior authors consult table of titles for presentation time

(please note that some changes have been made since the publication of the preliminary program matrix)

\begin{tabular}{|c|c|c|c|c|c|c|c|c|c|c|}
\hline & Sun. & Mon. & $10 / 6$ & Tues. & $10 / 7$ & Wed. & Thurs. & $10 / 9$ & Fri. 1 & \\
\hline & $\| / I I$ & 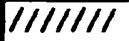 & $/ / / / / / /$ & Sess. 3 & Sess. 4 & $/ / / /$ & Sess. 5 & Sess. 4 & Sess. 5 & Sess. 7 \\
\hline Time: & $1 / / /$ & $/ / / / / / /$ & $/ / / / / / /$ & \|\|\|\|$/ \|$ & $11 / 1 / 11$ & $/ / / / / /$ & $1 / 1 / / 1 / 1$ & $\|/\| /\|/\|$ & $\|/\| / \| I /$ & \|\|\|\|$\|$ \\
\hline $00-$ & $1 / / /$ & $\mid / / / / / /]$ & $/ / / / / / /$ & $3-1$ & 4-1 & $/ / / /$ & $\overline{5-1}$ & $4-20$ & $5-7$ & $7-1$ \\
\hline 40 & $/ / / /$ & $8: 20-c$ & pening & $3-2$ & $4-2$ & $1 / / / 1$ & $5-2$ & .21 & $5-8$ & $7-2$ \\
\hline & $/ / / /$ & Remarks: & & $3-3$ & $4-3$ & $/ / / / 1$ & $5-3$ & 22 & -5 & $7-3$ \\
\hline & $/ / / /$ & Gene & & $3-4$ & 4 & $/ / / /$ & 5 & 23 & $5-10$ & $\sqrt{7-4}$ \\
\hline & $/ / / /$ & & ena & $3-5$ & $4-5$ & $1 / 1 / 1$ & 5 & $\overline{24}$ & $5-11$ & $7-5$ \\
\hline & $1 / / /$ & & Session & $3-6$ & 4-6 & $1 / 1 /$ & $5-6$ & $4-25$ & $5-12$ & $7-6$ \\
\hline n & $\begin{array}{l}/ / / / \\
/ / / /\end{array}$ & $\begin{array}{l}I I I I I I I \\
\text { Sess. } 1\end{array}$ & $\begin{array}{l}1 / I / I / I \\
\text { Sess. } 2\end{array}$ & $\begin{array}{l}1 / 1 / / I \\
\text { Sess. } 3\end{array}$ & $\begin{array}{l}I / I / I / \\
\text { Sess. } 4\end{array}$ & $\begin{array}{l}1 / 1 / / 1 \\
/ / / / /\end{array}$ & $\begin{array}{l}1 / 1 / / 1 / 1 \\
\text { Sess. } 6\end{array}$ & $\begin{array}{l}\text { I/I/I/I } \\
\text { Sess. } 8\end{array}$ & $\begin{array}{l}1 / 1 / 1 / 1 \\
\text { Sess. } 9\end{array}$ & $\begin{array}{l}1 / 1 / 1 / 1 \\
\text { Sess. } 10\end{array}$ \\
\hline & $1 / 1 /$ & $1-1$ & $2-1$ & $3-7$ & $\longdiv { 4 - 7 }$ & $1 / 1 /$ & $6-1$ & $8-1$ & $9-1$ & $10-1$ \\
\hline & $1 / 1 /$ & $1-2$ & 2-2 & $3-8$ & $4-8$ & $1 / 1 / 1$ & $6-2$ & $8-2$ & $9-2$ & $10-2$ \\
\hline & $/ / / /$ & $1-3$ & $2-3$ & $3-9$ & 4-9 & $/ / / /$ & $6-3$ & $8-3$ & 9 & $10-3$ \\
\hline & $/ / / /$ & $1-4$ & $2-4$ & $3-10$ & $4-10$ & $/ / / / \mid$ & $\overline{6-4}$ & $8-4$ & $9-4 / 9-5$ & $10-4$ \\
\hline & $/ / / /$ & $\|/\| /\|/\|$ & $\|/ / / / /\|$ & $\|/\| / \| / I$ & $111 / 111$ & $/ / / / / 1$ & $1 / / / / 1 / 1$ & $\|/\| /\|/\|$ & $12: 00-$ & $2: 30$ \\
\hline & $/ / / /$ & Sess. 1 & Sess. 2 & Sess. 3 & Sess. 4 & $/ / / / / /$ & Sess. 6 & Sess. 8 & losing $R$ & nark \\
\hline & $/ / / /$ & $1-5$ & $2-5$ & $3-11$ & 4-11 & $1 / 1 /$ & $6-5$ & & Gener & \\
\hline & $/ / / /$ & $1-6$ & $2-6$ & $3-12$ & $4-12$ & $1 / / 1 /$ & 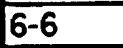 & 18 & & ssion \\
\hline & $/ / / /$ & $1-7$ & $2-7$ & $3-13$ & $4-13$ & $1 / / / 1$ & $6-7$ & 18 & $\|1\|\|\|$ & $/ /\|/\| /$ \\
\hline & $/ / / /$ & $\overline{1-8}$ & $2-$ & $3-14$ & 4-14 & $1 / 1 /$ & $6-8$ & $8-8$ & $\mid / /\|/\|$ & $/ / /\|/\|$ \\
\hline & $/ / / /$ & $1-9$ & $2-9$ & $3-15$ & 4-15 & $1 / 11$ & $6-9$ & 8 & $/ / / / / / \|$ & $/ / \| / / /$ \\
\hline & $1 / / /$ & $\|/ I / / /\|$ & $1 / 1 / / / /$ & $\|/\| / I / I$ & $\| / 1 / 1 /$ & $/ / / / / 1$ & $\| / / / / / 1 /$ & $\| / / / / / I$ & $\mid / / / / \|$ & $\|/\| / \|$ \\
\hline & $/ / / /$ & $1-10$ & $2-10$ & $3 / 16$ & 4-16 & $1 / 1 / 1$ & $6-10$ & & $/ / / / / /$ & $/ / / / / \|$ \\
\hline & $1 / / 1$ & $1-11$ & 2 & $3-17$ & 4-17 & $/ / / / 1$ & $6-11$ & & $1 / 1 / 1 / 1$ & $1 / 1 / 1 / 1$ \\
\hline $4: 2$ & $/ / / /$ & $1-12$ & $2-12$ & $3-18$ & 4-18 & $1 / 1 /$ & $6-12$ & $8-12$ & $/ / / / / / 1$ & $/ / / /\|/\|$ \\
\hline $4: 40-5: 00$ & $/ / / /$ & $1-13$ & $2-13$ & $3-19$ & 4-19 & $1 / 1 /$ & $6-13$ & $8-13$ & $\mid / / / / / /$ & $\|/\| / \|$ \\
\hline & $1 / 1 / 1$ & $\|/ 1 /\| / \|$ & $1 / 1 / 1 / \|$ & $\|/\| /\|/\|$ & $/ / 1 / 1 / 1$ & $1 / 1 / / 1$ & 111111 & $1 / 1 / / 1$ & $1 / 1 / / / 1$ & $\|/\| / \|$ \\
\hline oster sessions & 1,3 & $5,7,8,1$ & & & & $2,4,6$ & 6,9 & & & \\
\hline
\end{tabular}




\section{4th International Symposium On Environmental Geochemistry - PROGRAM}

\begin{tabular}{llll} 
SENIOR AUTHOR & TITLE & COUNTRY P/O* $\begin{array}{l}\text { Oral: } \\
\text { Session- } \begin{array}{l}\text { Poster } \\
\text { Dates } \\
\text { Sequence* Sequence* }\end{array}\end{array}$ \\
\hline
\end{tabular}

SPECIAL SESSION-Guest Speakers

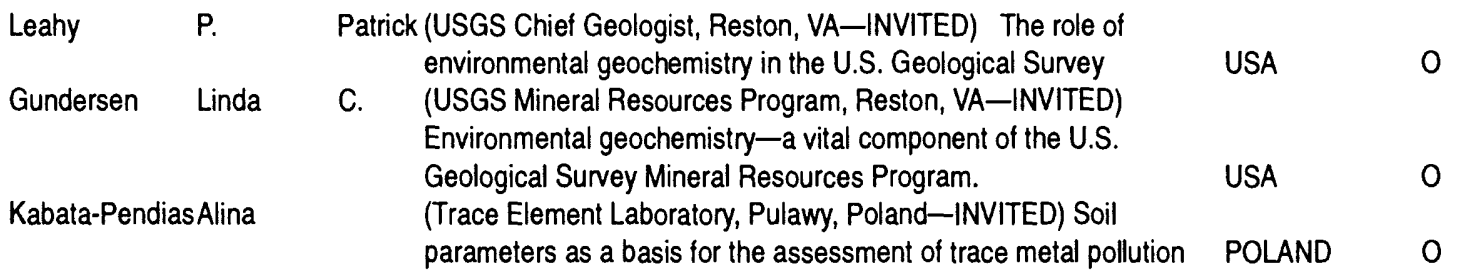

Session 1. Mine Drainage Formation and Geochemistry

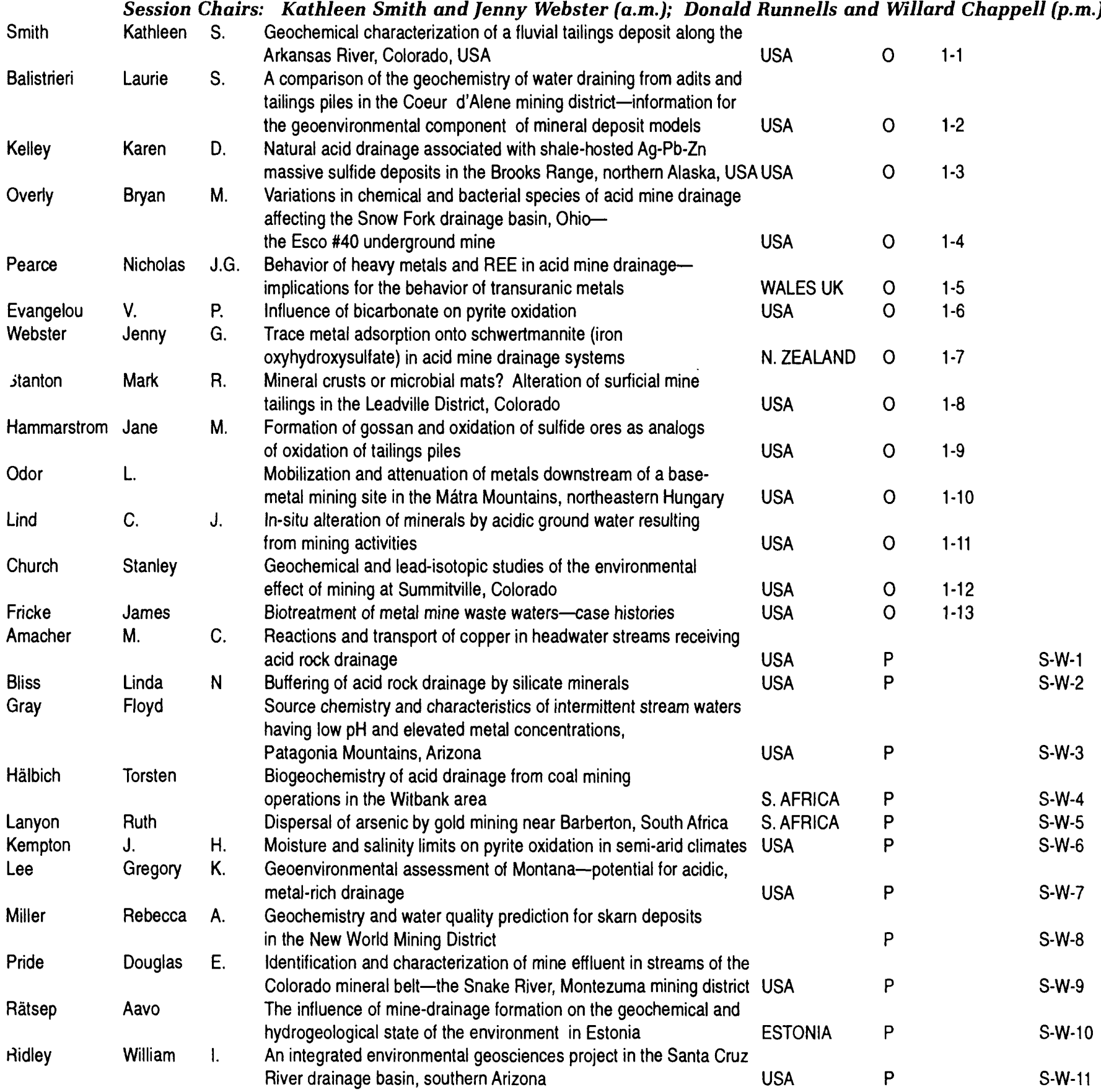

*Presentation type ( $O=$ oral; see program matrix for session number, date, and time. $P=$ poster; see program matrix for session dates) *Poster presentation times ( $S-W=S u n d a y-W e d n e s d a y ; W-F=$ Wednesday - Friday) 
Session 2. Geochemistry of Fresh Water \& Marine Environments

Session Chairs: Frank Manheim and Edeltrauda Helios Rybicka (a.m.); Joy Rae and Martin Fey (p.m.)

\begin{tabular}{|c|c|c|c|c|c|c|c|}
\hline McLemore & V. & T. & $\begin{array}{l}\text { Geology and geochemistry of water and stream-sediment samples } \\
\text { of the upper Pecos River Wilderness area, eastern New Mexico }\end{array}$ & USA & 0 & $2-1$ & \\
\hline Reid & Caroline & & Lead and zinc contamination of sediments in Zoar Vlei, & & & & \\
\hline & & & Cape Peninsula, South Africa & S. AFRICA & 0 & $2-2$ & \\
\hline Birch & Gavin & $\mathrm{F}$. & $\begin{array}{l}\text { Towards a contaminant model for Port Jackson—Sydney's } \\
\text { main estuary }\end{array}$ & AUSTRALIA & 0 & $2-3$ & \\
\hline Klavins & Maris & & Metal fluxes and accumulation in lakes of Latvia & LATVIA & 0 & $2-4$ & \\
\hline Zober & Steffen & & $\begin{array}{l}\text { Hydrological explanation of the heavy metals concentration in } \\
\text { the Wyszogrod Island, Vistula River, Plock, Poland }\end{array}$ & GERMANY & 0 & $2-5$ & \\
\hline Parsons & Michael & B. & $\begin{array}{l}\text { Hydrogeochemical controls on trace element release from the } \\
\text { Penn Mine base metal slag dump, Calaveras County, California- } \\
\text { linking field, laboratory, and geochemical modeling studies }\end{array}$ & USA & 0 & $2-6$ & \\
\hline Manheim & Frank & $T$. & $\begin{array}{l}\text { Mapping chemical contaminants in estuarine and coastal marine } \\
\text { sediments-new approaches to validating and using historical data }\end{array}$ & USA & 0 & $2-7$ & \\
\hline Lambeth & Robert & $\mathrm{H}$. & $\begin{array}{l}\text { Metal release and recolonization characteristics of tailings in a } \\
\text { marine environment-a laboratory study and site demonstration }\end{array}$ & USA & 0 & $2-8$ & \\
\hline Knesl & Oliver & & $\begin{array}{l}\text { A geochemical investigation of the water and sediments of } \\
\text { Barber's Pan, North West Province }\end{array}$ & S. AFRICA & 0 & $2-9$ & \\
\hline Matthai & C. & & $\begin{array}{l}\text { The application of the equilibrium partitioning method in surficial } \\
\text { sediments near a deepwater ocean outfall off Malabar, } \\
\text { Sydney, Australia }\end{array}$ & AUSTRALIA & 0 & $2-10$ & \\
\hline Sullivan & Annett & B. & $\begin{array}{l}\text { Temporal variation in the concentrations and speciation of metals } \\
\text { in Peru Creek, Summit County, Colorado }\end{array}$ & USA & 0 & 2-11 & \\
\hline Schettler & Georg & & Lacustrine records of heavy metal pollution-problems of dating & GERMANY & 0 & $2-12$ & \\
\hline Taylor & S. & E. & Contaminant dynamics in Port Jackson Estuary, Sydney, Australia & AUSTRALIA & 0 & $2-13$ & \\
\hline Brown & Kevin & L. & Metals in an estuarine system-sources and sinks & N. ZEALAND & $\mathbf{P}$ & & W-F-1 \\
\hline Margolina & Sofia & E. & The determination of heavy metal fractions in estuarine sediments & RUSSIA & $\mathrm{P}$ & & W-F-2 \\
\hline $\begin{array}{l}\text { Majer } \\
\text { Helios Rybicka }\end{array}$ & $\begin{array}{l}\text { Vladimir } \\
\text { E. }\end{array}$ & & $\begin{array}{l}\text { Pollution of Czech freshwaters by trace elements } \\
\text { Impact of the } \mathrm{Pb}-\mathrm{Zn} \text { industry on the contamination of the }\end{array}$ & CZECH REP. & $\mathbf{P}$ & & W-F-3 \\
\hline & & & Przemsza River, Upper Silesia, Poland & POLAND & $P$ & & $W \cdot F-4$ \\
\hline Kim & Kyoung-V & oong & $\begin{array}{l}\text { Heavy metal contamination in dusts and stream sediments, } \\
\text { Taejon area, Korea }\end{array}$ & KOREA & $\mathbf{P}$ & & W-F-5 \\
\hline Kralik & Martin & & $\begin{array}{l}\text { Unique ground water (karst) monitoring system as an important } \\
\text { tool of drinking water protection in Austria }\end{array}$ & AUSTRIA & $\mathbf{P}$ & & W-F-6 \\
\hline Rosales-Hoz & L. & & $\begin{array}{l}\text { Distribution of trace and major elements in surface sediments } \\
\text { from Coatzacoalcos River, Mexico }\end{array}$ & MEXICO & $\mathbf{P}$ & & W-F-7 \\
\hline Savchenko & Vladimir & & $\begin{array}{l}\text { Low-water sediment in rivers of Belarus-origin, mineralogical } \\
\text { and geochemical composition, potential for use in } \\
\text { environmental assessments }\end{array}$ & BELARUS & $\mathrm{P}$ & & $W-F-8$ \\
\hline Savchenko & Vladimir & & $\begin{array}{l}\text { Some approaches to the biogeochemical study of } \\
\text { contaminated river ecosystems }\end{array}$ & BELARUS & $\mathbf{P}$ & & W-F-9 \\
\hline Schettler & Georg & & $\begin{array}{l}\text { Lead isotope anomalies in Maar Lake sediments- } \\
\text { indications of extensive lead mining in the Northwestern Eifel } \\
\text { (Germany) during the time of the Roman Empire }\end{array}$ & GERMANY & $\mathrm{P}$ & & $W-F-10$ \\
\hline Perkins & W. & $T$. & $\begin{array}{l}\text { Monitoring marine pollution and determining paleoclimate: } \\
\text { the application of laser ablation ICP-MS studies to } \\
\text { marine bivalve molluscs }\end{array}$ & WALES UK & $\mathbf{P}$ & & $W-F-11$ \\
\hline Shakhverdov & v. & & $\begin{array}{l}\text { Heavy metals as indicators of anthropogenic pollution of } \\
\text { bottom sediments in Neva Bay }\end{array}$ & RUSSIA & $\mathrm{P}$ & & W-F-12 \\
\hline Zhamoida & Vladimir & A. & $\begin{array}{l}\text { Modern shallow-water Fe-Mn concretions as an indicator of } \\
\text { the contamination of marine environments-a new type of } \\
\text { environmental geochemical monitoring }\end{array}$ & RUSSIA & $\mathrm{P}$ & & W-F-13 \\
\hline
\end{tabular}


Session 3. SEGH-Sponsored Session - Environmental Geochemistry and Health Session Chairs: Betsy Kagey and Iain Thornton (a.m.); Ron Fuge and Larry Gough (p.m.)

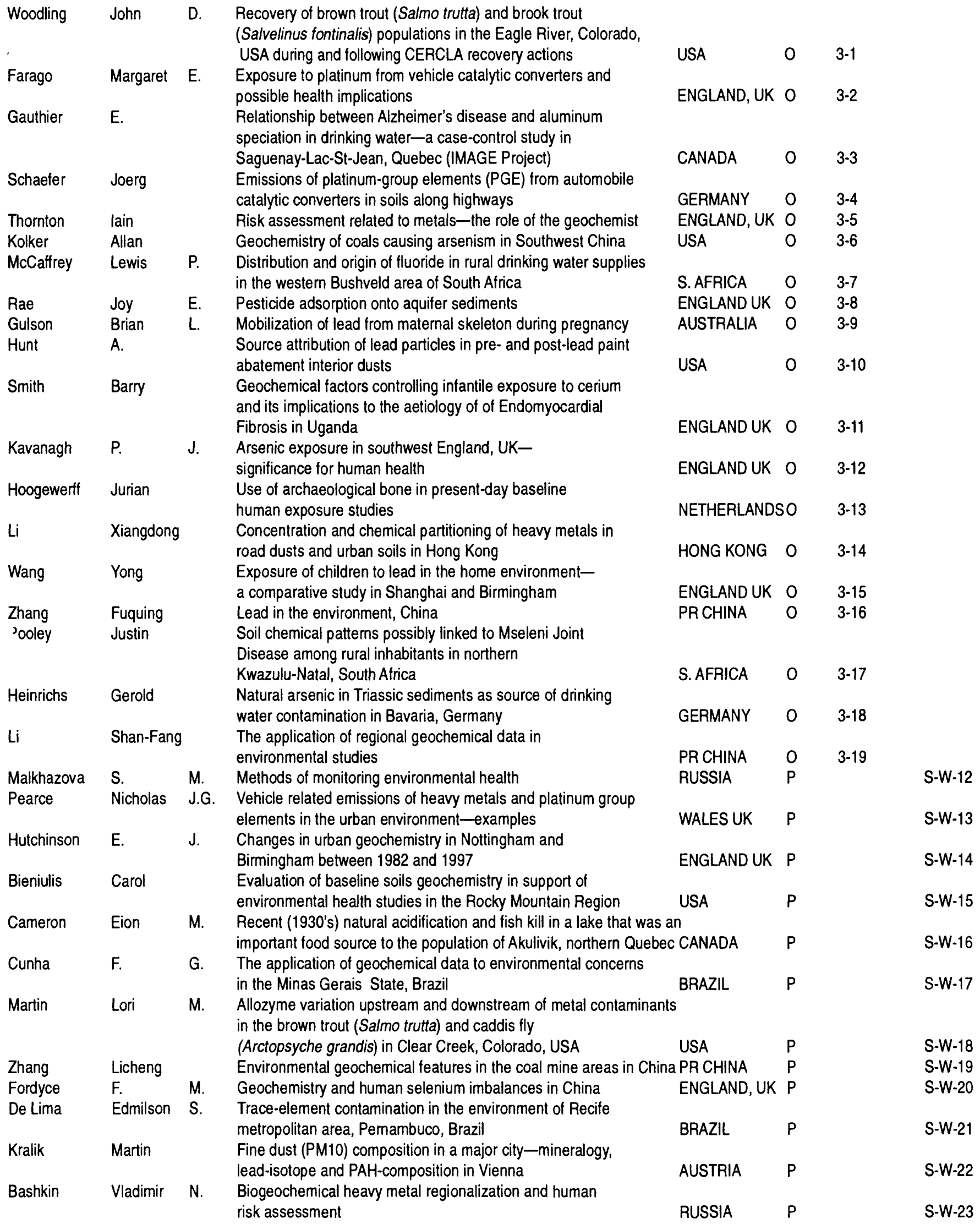




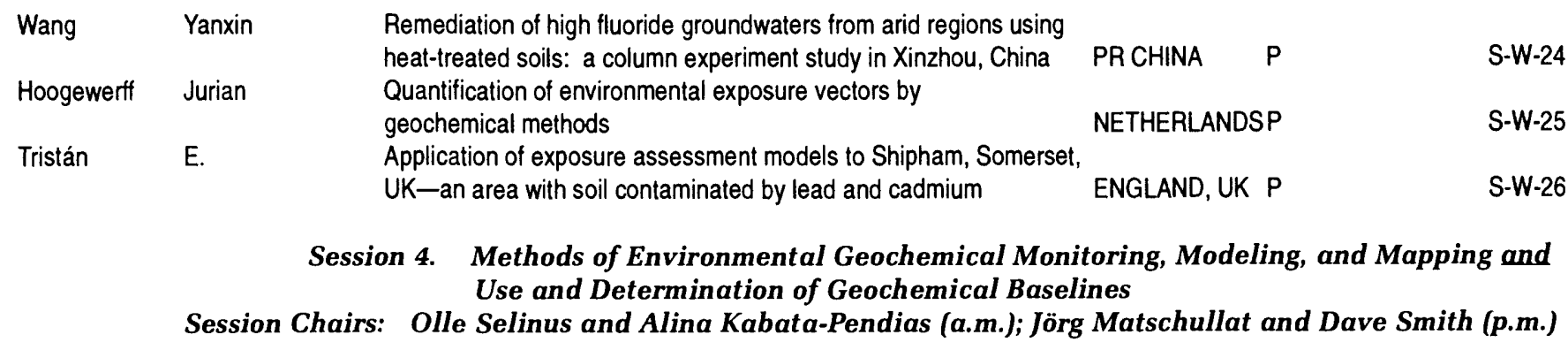

\begin{tabular}{|c|c|c|c|c|c|c|}
\hline Talbot & D. & K. & $\begin{array}{l}\text { A comparison of field and laboratory analytical methods of radon- } \\
\text { potential mapping in areas with and without glacial drift coverage }\end{array}$ & ENGLAND UK & 0 & $4-1$ \\
\hline Chaffee & Maurice & A. & $\begin{array}{l}\text { Discriminating between natural and anthropogenic anomalies in } \\
\text { the surficial environment in Yellowstone National Park, Idaho, } \\
\text { Montana, and Wyoming }\end{array}$ & USA & 0 & $4-2$ \\
\hline Ander & E. & $\mathrm{L}$. & $\begin{array}{l}\text { Temporal variability in the geochemistry of waters from } \\
\text { abandoned coal mines, County Durham, United Kingdom }\end{array}$ & ENGLAND UK & 0 & $4-3$ \\
\hline Swennen & Rudy & & $\begin{array}{l}\text { Unravelling the degree and the history of environmental pollution } \\
\text { based on the evaluation of vertical geochemical profiles in } \\
\text { overbank sediments }\end{array}$ & BELGIUM & 0 & $4-4$ \\
\hline Selinus & Olle & & $\begin{array}{l}\text { Integrating GIS and multivariate statistics in environmental } \\
\text { geochemistry }\end{array}$ & SWEDEN & 0 & $4-5$ \\
\hline Wang & Bronwen & & Trace Elements in the Kuskokwim River, Alaska & USA & 0 & $4-6$ \\
\hline Van Tienhoven & Mieke & & $\begin{array}{l}\text { Baseline survey of air pollution impacts on soil and water quality } \\
\text { in Mpumalanga Province, South Africa }\end{array}$ & S. AFRICA & 0 & $4-7$ \\
\hline Hudson-Edwarc & dskaren & A. & $\begin{array}{l}\text { The use of Holocene floodplain sedimentary sequences } \\
\text { for geochemical mapping }\end{array}$ & ENGLAND UK & 0 & $4-8$ \\
\hline Russ & Jon & & $\begin{array}{l}\text { A new paleoclimate indicator based on AMS }{ }^{14} \mathrm{C} \text { dates of biogenic } \\
\text { whewellite }\end{array}$ & USA & 0 & $4-9$ \\
\hline Posey & Harry & & $\begin{array}{l}\text { Establishing pre-disturbance water quality standards in areas of } \\
\text { natural acid-metal contamination, upper Alamosa River, } \\
\text { southern Colorado }\end{array}$ & USA & 0 & $4-10$ \\
\hline Caron & Francois & & $\begin{array}{l}\text { A large-scale laboratory experiment to determine the mass } \\
\text { transfer of } \mathrm{CO}_{2} \text { from a sandy soil to moving ground water }\end{array}$ & CANADA & 0 & $4 \cdot 11$ \\
\hline Dodds & Heather & A. & $\begin{array}{l}\text { Classifying and mapping the sensitivity of South African } \\
\text { highveld soils to acidification }\end{array}$ & S. AFRICA & 0 & $4-12$ \\
\hline Matschullat & Jörg & & $\begin{array}{l}\text { Crustose lichens-capable of monitoring the atmospheric } \\
\text { deposition of trace elements and organohalogens? }\end{array}$ & GERMANY & 0 & $4-13$ \\
\hline Zielinski & Robert & A. & $\begin{array}{l}\text { Uranium and uranium isotopes as tracers of nutrient addition- } \\
\text { a case study in south Florida }\end{array}$ & USA & 0 & $4-14$ \\
\hline Reimann & C. & & The "Kola Ecogeochemistry" Project & NORWAY & 0 & $4-15$ \\
\hline Runnells & D. & D. & $\begin{array}{l}\text { Determination of natural background concentrations of dissolved } \\
\text { components in water at mining, milling, and smelting sites }\end{array}$ & USA & 0 & $4-16$ \\
\hline McMartin & $\mathrm{I}$. & & $\begin{array}{l}\text { Distribution of trace metals in soils near the base metal smelter } \\
\text { at Flin Flon, Manitoba-natural and anthropogenic enrichments } \\
\text { from a remote single point source area }\end{array}$ & CANADA & 0 & $4-17$ \\
\hline de Bruin & D. & & $\begin{array}{l}\text { Environmental applications of the regional geochemical mapping } \\
\text { of soils and stream sediments in South Africa }\end{array}$ & S. AFRICA & 0 & $4-18$ \\
\hline Seal, II & Robert & R. & $\begin{array}{l}\text { Stable isotope characteristics of waters draining massive sulfide } \\
\text { deposits in the eastern United States }\end{array}$ & USA & 0 & $4-19$ \\
\hline Smith & Barry & & $\begin{array}{l}\text { High resolution baseline mapping of hydrochemical processes } \\
\text { and their correlation with geochemical anomalies and anthropogenic } \\
\text { activities-Wales and Welsh borders }\end{array}$ & ENGLAND UK & 0 & $4-20$ \\
\hline Wawrzynski & Alecia & $\mathrm{L}$. & $\begin{array}{l}\text { The utilization of high spectral resolution imagery and field } \\
\text { spectra for the detection and monitoring of mining sites }\end{array}$ & USA & 0 & $4-21$ \\
\hline Magnuszewski & Artur & & $\begin{array}{l}\text { Ground truth versus a GIS model-the ground water quality of the } \\
\text { Vistula River floodplain near the city of Plock, Poland }\end{array}$ & POLAND & 0 & $4-22$ \\
\hline $\begin{array}{l}\text { Hirner } \\
\text { Tarvainen }\end{array}$ & $\begin{array}{l}\text { A. } \\
\text { Timo }\end{array}$ & V. & $\begin{array}{l}\text { Testing contaminant mobility in soils and waste materials } \\
\text { Delineating risk areas of contaminated ground water using }\end{array}$ & GERMANY & 0 & $4-23$ \\
\hline & & & geochemical databases & & & $4-24$ \\
\hline Holmes & Charles & & Ecological changes in Florida Bay-can we tell when it happened? & USA & 0 & $4-25$ \\
\hline
\end{tabular}




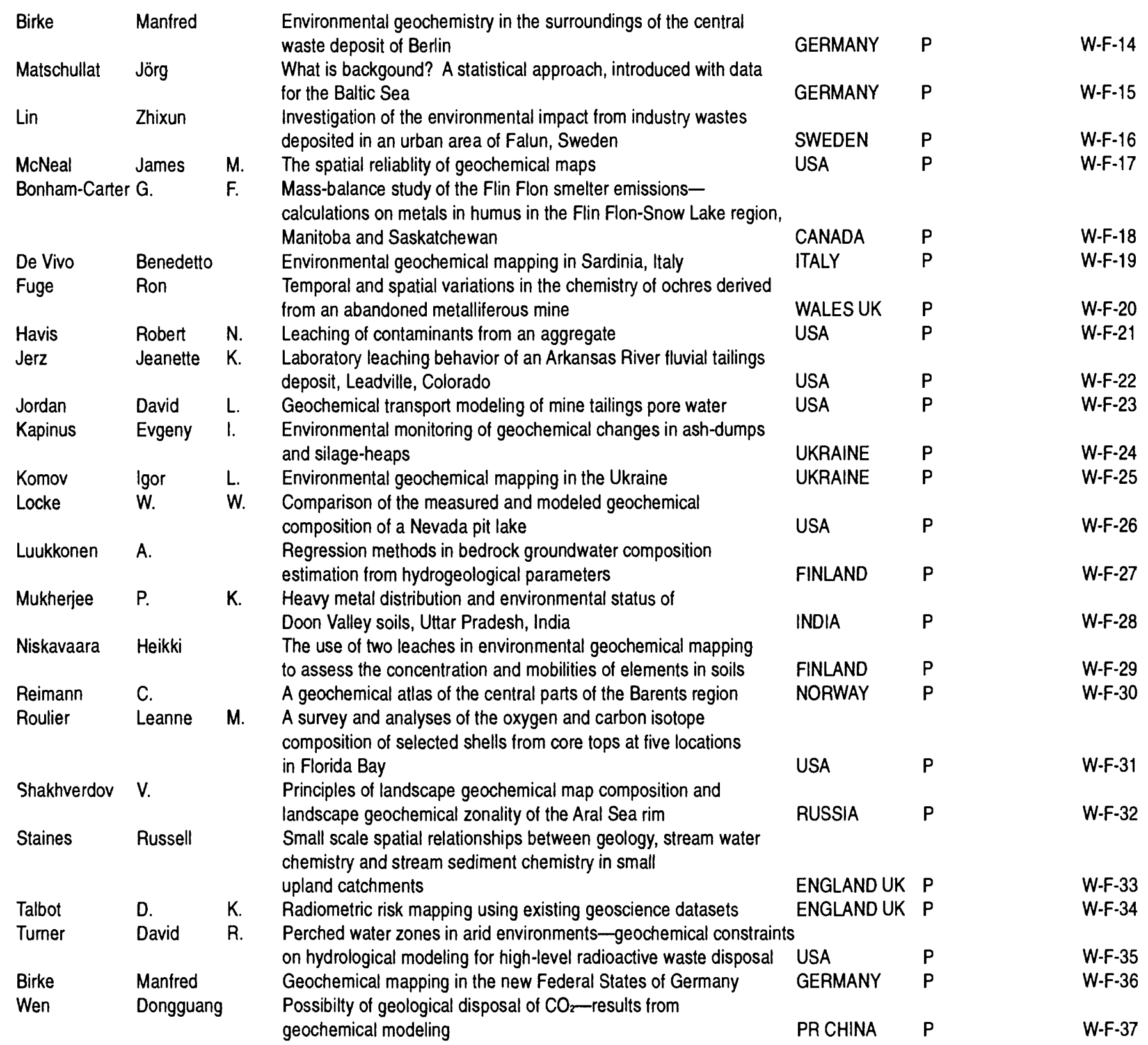

Session 5. Trace Substances, Ecosystems, and Bioavailability - aquatic/atmosphere

Session Chairs: Laurie Balistrieri and David Levy (Thursday a.m.); John Gray and Gianni Cortecci (Friday a.m.)

\begin{tabular}{|c|c|c|c|c|c|c|}
\hline Gray & David & J. & $\begin{array}{l}\text { Acid/saline ground waters in the southern Yilgarn Craton, } \\
\text { western Australia }\end{array}$ & AUSTRALIA & 0 & 5-1 \\
\hline Varsányi & Iren & & $\begin{array}{l}\text { Contamination of ground water in a varying hydrogeochemical } \\
\text { environment, southeast Hungary }\end{array}$ & HUNGARY & 0 & $5-2$ \\
\hline Bourg & Alain & C.M. & $\begin{array}{l}\text { Solubility of heavy metals in relation to the geological context- } \\
\text { a theoretical approach }\end{array}$ & FRANCE & 0 & \\
\hline Edwards & Robert & J. & The development of a biological toxicity based test for water quality & ENGLAND, UK & 0 & \\
\hline Rasmussen & Pat & E. & $\begin{array}{l}\text { Emissions of mercury to the atmosphere-natural sources } \\
\text { and pathways }\end{array}$ & CANADA & 0 & \\
\hline Dinelli & Enrico & & $\begin{array}{l}\text { Isotopic and chemical compositions of rain and snow } \\
\text { precipitation at Bologna, Italy }\end{array}$ & ITALY & 0 & \\
\hline Lee & Jin-Soo & & $\begin{array}{l}\text { Dispersion and enrichment of potentially toxic elements in areas } \\
\text { underlain by black shales and slates in Korea }\end{array}$ & KOREA & 0 & \\
\hline Levy & David & B. & $\begin{array}{l}\text { Geochemistry of arsenic and fluorine in shallow ground water- } \\
\text { eastern Owens Lake, California }\end{array}$ & USA & 0 & \\
\hline omagalski & Joseph & $\mathrm{L}$. & $\begin{array}{l}\text { Mercury occurrence, transport, and speciation in the } \\
\text { Sacramento River Basin, California }\end{array}$ & USA & 0 & \\
\hline
\end{tabular}




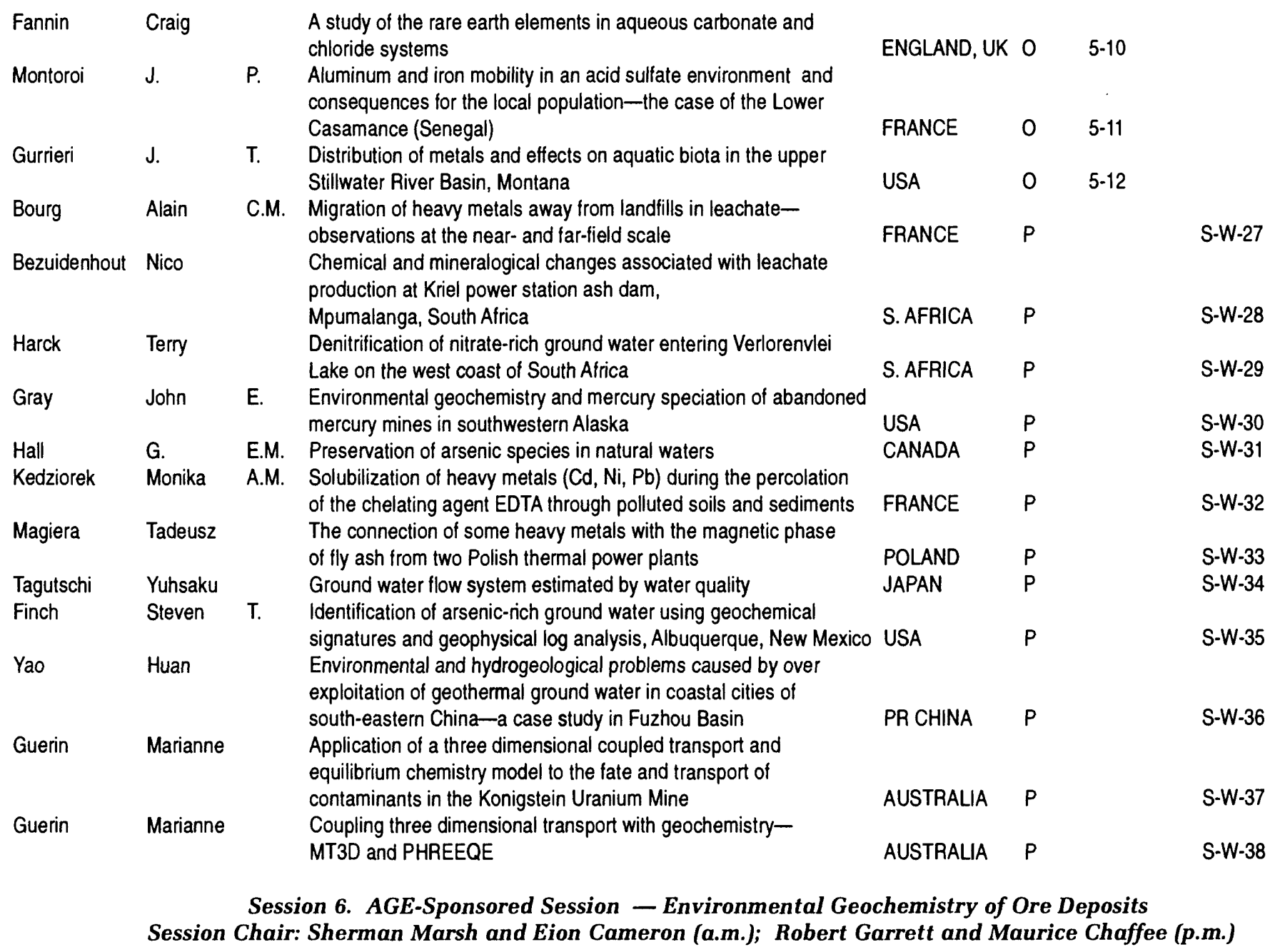

Loukola-Ruskeeniemi Kirsti Natural analogue for bedrock pollution-environmental impact of

\begin{tabular}{|c|c|c|c|c|c|c|}
\hline & & & $\mathrm{Ni}-\mathrm{Cu}-\mathrm{Zn}$-rich black shales at Talvivaara, Finland & FINLAND & 0 & $6-1$ \\
\hline Berner & Zsolt & & $\begin{array}{l}\text { Manifold heavy metal and As contamination by a German } \\
\mathrm{Zn}-\mathrm{Pb} \text { deposit with a two thousand year-old mining history }\end{array}$ & GERMANY & 0 & $6-2$ \\
\hline Rytuba & James & J. & Environmental geochemistry of mercury deposits in the & & & \\
\hline & & & Coast Range mercury belt, California & USA & 0 & $6-3$ \\
\hline Steele & Kenneth & F. & $\begin{array}{l}\text { Comparison of ground water chemistry from the carbonate } \\
\text { platform region of the Ozark Mountains, USA }\end{array}$ & USA & 0 & $6-4$ \\
\hline Klassen & Rodney & A. & $\begin{array}{l}\text { The effects of glacial dispersal and global processes on till } \\
\text { geochemistry, Labrador, Canada }\end{array}$ & CANADA & 0 & $0-5$ \\
\hline shley & Roger & P. & $\begin{array}{l}\text { Environmental geochemistry of gold deposits in the } \\
\text { Mother Lode Belt, California }\end{array}$ & USA & 0 & $6-6$ \\
\hline ieto & Gloria & R. & $\begin{array}{l}\text { Geochemistry of heavy metals derived from gold sulfide } \\
\text { minerals, Marmato District, Columbia }\end{array}$ & COLUMBIA & 0 & -7 \\
\hline Fuge & Ron & & $\begin{array}{l}\text { The behavior of } \mathrm{Cd} \text { and } \mathrm{Hg} \text { during weathering of sphalerite- } \\
\text { environmental implications }\end{array}$ & WALES UK & 0 & 8 \\
\hline Atkins & David & A. & $\begin{array}{l}\text { Measurement and simulation of pyrite oxidation in the blasted } \\
\text { rock of an open-pit mine }\end{array}$ & USA & 0 & 6-9 \\
\hline Klusman & Ronald & W. & $\begin{array}{l}\text { Measurement of gas exchange processes between soils and the } \\
\text { atmosphere and applications in environmental and } \\
\text { exploration geochemistry }\end{array}$ & USA & 0 & $6-10$ \\
\hline Gray & John & E. & Environmental studies of mineral deposits in Alaska & USA & 0 & 11 \\
\hline Eary & & E. & Effects of evapo-concentration on water quality in mine pit lakes & USA & 0 & 12 \\
\hline ässer & Walter & & $\begin{array}{l}\text { Environmental impacts of lignite open-cast mining areas in } \\
\text { eastern Germany }\end{array}$ & GERMANY & 0 & \\
\hline andvold & Lynn & & $\begin{array}{l}\text { A study of the analytical variation of sampling and analysis of } \\
\text { stream-sediments from mining and milling contaminated areas }\end{array}$ & USA & & \\
\hline
\end{tabular}




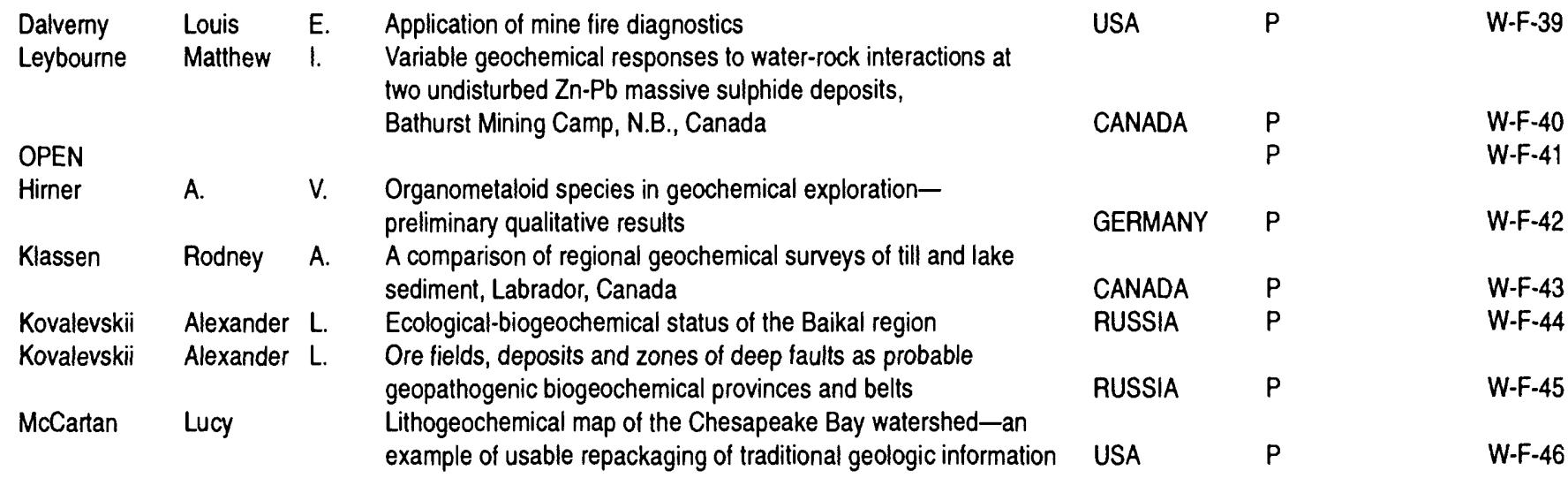

\section{Session 7. Environmental Analytical Techniques \& Applications} (Session Chairs: Gwennyth Hall and James Crock)

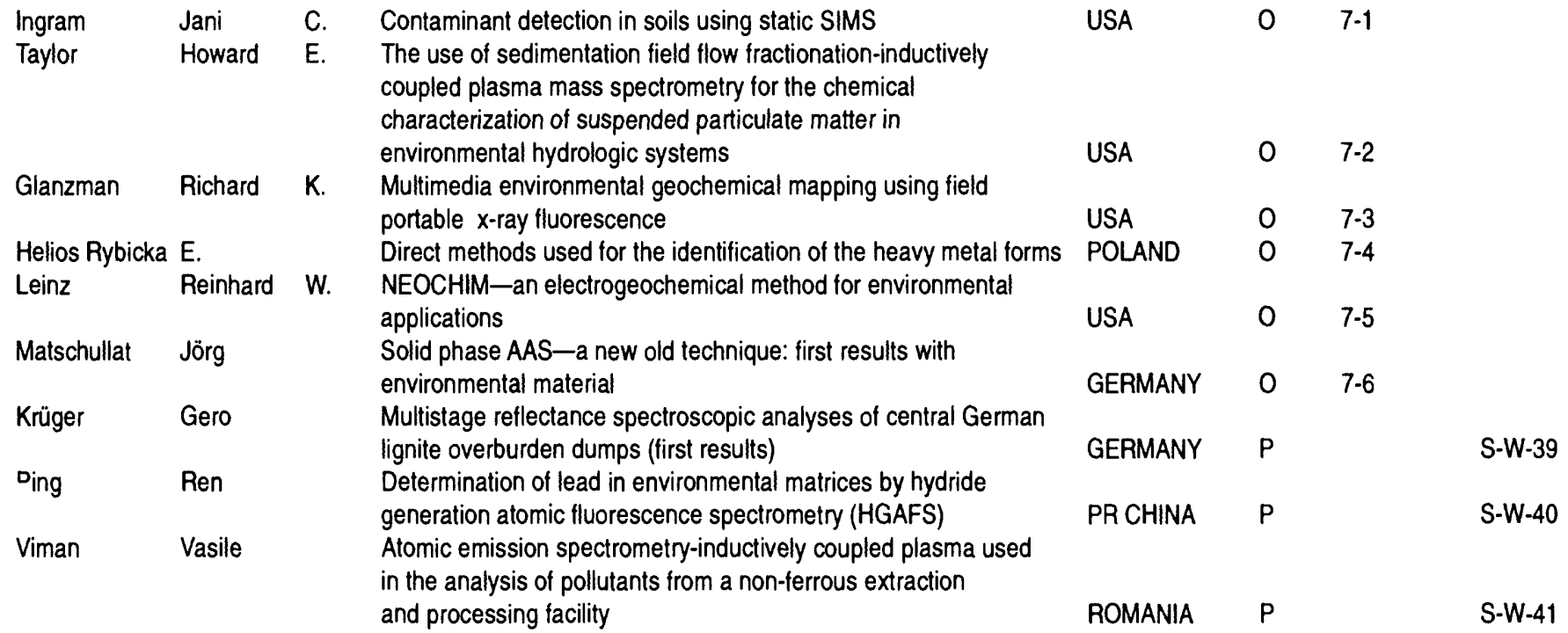

Session 8. Trace Substances, Ecosystems, and Bioavailability - terrestrial

(Session Chairs: William Orem and Irina Stangeeva (a.m.); Harald Püchelt and Rama Kotra (p.m.)

\begin{tabular}{|c|c|c|c|c|c|c|}
\hline \multirow{2}{*}{$\begin{array}{l}\text { Fuge } \\
\text { Van der Sluys }\end{array}$} & \multicolumn{2}{|l|}{ Ron } & Platinum group elements in road-side dust & WALES UK & 0 & $8-1$ \\
\hline & Jan & & \multicolumn{4}{|l|}{ Geochemistry of overbank sediments in Belgium and Luxembourg- } \\
\hline Makino & T. & & $\begin{array}{l}\text { The investigation of the redox reactions and adsorption of chromium } \\
\text { in soils }\end{array}$ & JAPAN & 0 & $8-3$ \\
\hline Asami & Teruo & & Pollution of sediments, soils, and plants by thallium & JAPAN & 0 & $8-4$ \\
\hline Garrett & Robert & G. & Some methods for estimating phytoavailable cadmium in prairie soils & SCANADA & 0 & $8-5$ \\
\hline Räisänen & Marja & L. & $\begin{array}{l}\text { The response of the interlayering of clay minerals to the mobility } \\
\text { of } A \text { l in acidified podzols }\end{array}$ & FINLAND & 0 & $8-6$ \\
\hline Mielke & Howard & W. & $\begin{array}{l}\text { Soil } \mathrm{Pb}, \mathrm{Zn} \text {, and } \mathrm{Cd} \text { in metropolitan New Orleans-their } \\
\text { geochemical characterization and association }\end{array}$ & USA & 0 & $8-7$ \\
\hline Dinelli & Enrico & & $\begin{array}{l}\text { Plant-soil relationships in the serpentinite screes of Mt. Prinzera, } \\
\text { northern Apennines, Italy }\end{array}$ & ITALY & 0 & $8-8$ \\
\hline Orem & William & $\mathrm{H}$. & $\begin{array}{l}\text { The biogeochemistry of sulfur in the freshwater Florida } \\
\text { everglades-sources, cycling, and relation to mercury methylation }\end{array}$ & USA & 0 & $8-9$ \\
\hline Harrison & Wendy & J. & $\begin{array}{l}\text { Acid buffering capacity and metals mobility in acid-impacted } \\
\text { agricultural soils, San Luis Valley, Colorado }\end{array}$ & USA & 0 & $8-10$ \\
\hline Püchelt & Harald & & $\begin{array}{l}\text { Uptake of trace elements by plants from soils contaminated by } \\
\text { mining activities in southwest Germany and north-central Mexico }\end{array}$ & GERMANY & 0 & $8-11$ \\
\hline Hall & G. & E.M. & $\begin{array}{l}\text { Compatibility of data derived from different selective extraction } \\
\text { schemes }\end{array}$ & CANADA & 0 & $8-12$ \\
\hline
\end{tabular}




\begin{tabular}{|c|c|c|c|c|c|c|}
\hline $\begin{array}{l}\text { Govil } \\
\text { Äyräs }\end{array}$ & $\begin{array}{l}\text { P. } \\
\text { Mätti }\end{array}$ & $\mathrm{K}$. & $\begin{array}{l}\text { Effect of industrial effluents on trace element mobility in soil } \\
\text { Distribution of sulphur and heavy metals in podzolized tills } \\
\text { in northern Finland }\end{array}$ & $\begin{array}{l}\text { INDIA } \\
\text { FINLAND }\end{array}$ & $8-13$ & S-W-42 \\
\hline Bailey & E. & A. & Mercury speciation in soils and vegetation, southwest Alaska & USA & $P$ & S-W-43 \\
\hline Bondar & Galina & S. & Assessment of suitability of some disturbed land for herb cultivation & UKRAINE & $P$ & S-W-44 \\
\hline Carranza-Edn & ards Arturo & & $\begin{array}{l}\text { Textural analysis and its importance as an indicator of energy levels } \\
\text { in environmental geochemistry }\end{array}$ & MEXICO & $\mathbf{P}$ & S-W-45 \\
\hline Evans, Jr. & Andrew & & $\begin{array}{l}\text { Biodegradation of }{ }^{14} \mathrm{C} \text { labeled organic acids and organo-metal } \\
\text { complexes in soil }\end{array}$ & USA & $\mathbf{P}$ & S-W-46 \\
\hline Nicholson & Keith & & Environmental geochemistry of boron & SCOTLAND UK & $P$ & S-W-47 \\
\hline Nowicki & Tom & & $\begin{array}{l}\text { Afforestation-induced enhancement of soil-solution aluminum and } \\
\text { manganese concentrations in South African highland catchments }\end{array}$ & S. AFRICA & $P$ & S-W-48 \\
\hline Gao & Xiaojiang & & $\begin{array}{l}\text { Environmental geochemistry of rare earth elements in a typical } \\
\text { landscape, Jiangxi, southern China }\end{array}$ & PR CHINA & $\mathbf{P}$ & S-W-49 \\
\hline Gennadiyev & A. & & Behavior of polycyclic aromatic hydrocarbons in soil ecosystems & RUSSIA & $\mathbf{P}$ & S-W-50 \\
\hline Gonzalez & Luz Miryan & & Heavy metals in soils of the Sabana de Bogota, Columbia & COLUMBIA & $P$ & S-W-51 \\
\hline Kadatsky & Valery & B. & $\begin{array}{l}\text { Heavy metals in humus and soil organic layers with } \\
\text { different human activities }\end{array}$ & BELARUS & $\mathrm{P}$ & S-W-52 \\
\hline Kasimov & $\mathrm{N}$. & S. & $\begin{array}{l}\text { The behavior of rocket-fuel components in soil and plants in the } \\
\text { Kazakhstan and Altay region of Russia }\end{array}$ & RUSSIA & $\mathbf{P}$ & S-W-53 \\
\hline Kotra & Rama & $\mathrm{K}$. & $\begin{array}{l}\text { Geochemistry of mercury and trace elements in organic-rich } \\
\text { sediments and vegetation from the everglades, south Florida }\end{array}$ & USA & 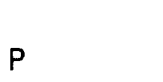 & S-W-54 \\
\hline Fumoto & T. & & Sulfate adsorption model for predicting soil acidification & JAPAN & $P$ & S-W-55 \\
\hline Rashed & M. & $\mathrm{N}$. & $\begin{array}{l}\text { Biogeochemistry of trace elements in plants and interactions with } \\
\text { soil around Nasser Lake, Egypt }\end{array}$ & EGYPT & $P$ & S-W-56 \\
\hline Rechcigl & Jack & E. & Environmental impact of phosphogypsum use in agriculture & USA & $P$ & S-W- 57 \\
\hline Semenov & Yury & M. & $\begin{array}{l}\text { Differentiation of heavy metals as a reflection of } \\
\text { landscape-use levels }\end{array}$ & RUSSIA & $P$ & S-W-58 \\
\hline Sakurai & Yasuhiro & & $\begin{array}{l}\text { Laboratory measurements of the absorption and oxidation of } \\
\text { sulfur dioxide by the soil surface }\end{array}$ & JAPAN & $P$ & S-W-59 \\
\hline Savchenko & Vladimir & & $\begin{array}{l}\text { Trace element distribution in soils and factors affecting metal } \\
\text { uptake by plants in the contaminated flood plain of the } \\
\text { Svisloch River, Belarus }\end{array}$ & BELARUS & $\mathrm{P}$ & S-W-60 \\
\hline Sonke & Jeroen & & $\begin{array}{l}\text { A chemical and mineralogical reconstruction of emissions from } \\
\mathrm{Zn} \text {-smelters in the Kempen region (Belgium), based on peat cores }\end{array}$ & NETHERLANDS & & S-W-61 \\
\hline Shtangeeva & Irina & & $\begin{array}{l}\text { Some pecularities of chemical element bioaccumulation in } \\
\text { different environmental samples }\end{array}$ & RUSSIA & $P$ & S-W-62 \\
\hline Strzyszcz & Zygmunt & & $\begin{array}{l}\text { Iron deposition and magnetic susceptibility of forest soils, } \\
\text { Katowice Province, Poland }\end{array}$ & POLAND & $P$ & S-W-63 \\
\hline Wang & Lijun & & $\begin{array}{l}\text { Environmental geochemistry of rare earth elements in } \\
\text { common soils of China }\end{array}$ & PR CHINA & $P$ & S-W-64 \\
\hline
\end{tabular}

\section{Session 9. Remediation of Mining-Related Disturbances (Session Chairs: Harry Posey and Suresh Kumar)}

\begin{tabular}{|c|c|c|c|c|c|c|}
\hline Rebedea & Irina & $\begin{array}{l}\text { An investigation into the mechanism by which synthetic zeolite } \\
\text { amendments reduce soil phytotoxicity }\end{array}$ & ENGLAND, UK & 0 & $9-1$ & \\
\hline Deissmann & Guido & $\begin{array}{l}\text { Geochemical assessment of passive treatment methods for acid } \\
\text { mine waters from a flooded uranium mine }\end{array}$ & GERMANY & 0 & $9-2$ & \\
\hline Vandiviere & M. & $\begin{array}{l}\text { Comparative testing between conventional and microencapulsation } \\
\text { approaches in controlling pyrite oxidation }\end{array}$ & USA & 0 & $9-3$ & \\
\hline Cheong & Young-Wook & $\begin{array}{l}\text { Metal removal efficiencies of substrates for treating acid mine } \\
\text { drainage of the Dalsung Mine, Korea }\end{array}$ & KOREA & 0 & $9-4$ & \\
\hline Bowell & R. & A review of sulfate removal options from mine waters & WALES UK & 0 & $9-5$ & \\
\hline $\begin{array}{l}\text { Joshi } \\
\text { Kumar }\end{array}$ & $\begin{array}{l}\text { D. } \\
\text { Suresh }\end{array}$ & $\begin{array}{l}\text { Characterization of gypsum mine wastelands and their rehabilitation } \\
\text { Rehabilitation induced vegetation progression at gypsum mined land } \\
\text { in western Raiasthan-analytical aporoaches and empirical evidence }\end{array}$ & $\begin{array}{l}\text { INDIA } \\
\text { dINDIA }\end{array}$ & $P$ & & $\begin{array}{l}W-F-47 \\
W-F-48\end{array}$ \\
\hline Lund & D. & $\begin{array}{l}\text { Uses of chemical speciation for impact evaluation and remediation } \\
\text { of mining waste }\end{array}$ & ENGLAND UK & $P$ & & W-F-49 \\
\hline $\mathrm{Ni}$ & Dagang & $\begin{array}{l}\text { Purification of toxic metal contaminated ground water using } \\
\text { Chitosan in partially converted crab shells }\end{array}$ & USA & $P$ & & W-F-50 \\
\hline Edwards & Robert & $\begin{array}{l}\text { Biogeochemical mechanisms influencing metal mobility in natural } \\
\text { and constructed wetlands }\end{array}$ & WALES UK & $P$ & & $W-F-51$ \\
\hline
\end{tabular}




\begin{tabular}{|c|c|c|c|c|c|c|c|}
\hline \multirow{2}{*}{$\begin{array}{l}\text { Thompson } \\
\text { Nord, Jr. }\end{array}$} & \multicolumn{2}{|l|}{ Bruce } & \multirow{2}{*}{$\begin{array}{l}\text { Adsorption of metal cations on manganese oxide-coated filter sand: } \\
\text { a novel method for water treatment } \\
\text { Three-dimensional nanocrystalline networks limit limestone drain } \\
\text { remediation-a role for environmental mineralogy }\end{array}$} & \multicolumn{2}{|c|}{ SCOTLAND UK P } & & \multirow[t]{2}{*}{ W-F-52 } \\
\hline & Gordon & $\mathrm{L}$. & & USA & $P$ & & \\
\hline & & & $\begin{array}{l}\text { on 10. Natural and Man-Made Radiogenic Hazards } \\
\text { (Session Chairs: Rich Wanty and John Glendinning) }\end{array}$ & & & & \\
\hline Kagan & Leonid & M. & $\begin{array}{l}\text { Chernobyl nuclides in soils and gamma-dose rate in the air } \\
\text { of Belarus }\end{array}$ & BELARUS & 0 & $10-1$ & \\
\hline Glendinning & John & & $\begin{array}{l}\text { Weathering and colloid mobility as factors influencing the } \\
\text { migration of radioactive elements at Steenkampskraal Mine } \\
\text { in the Northern Cape Province, South Africa }\end{array}$ & S. AFRICA & 0 & $10-2$ & \\
\hline Smith & Barry & & $\begin{array}{l}\text { The distribution of natural radioelements in ground waters } \\
\text { and post Cretaceous sediments from the southern } \\
\text { Mediterranean margin }\end{array}$ & ENGLAND UK & 0 & $10-3$ & \\
\hline Shvartsev & Stepan & L. & $\begin{array}{l}\text { The experience and the results for the disposal of liquid } \\
\text { radioactive waste (LRW) on the Siberian Chemical Industrial Plant }\end{array}$ & RUSSIA & 0 & $10-4$ & \\
\hline Mazeika & Jonas & & $\begin{array}{l}\text { Radiogeochemical mapping in the Ignalina Nuclear Power } \\
\text { Plant region- bottom sediments and soils }\end{array}$ & LITHUANIA & $P$ & & S-W-65 \\
\hline Shumlyanskiy & Vladkslav & 0. & $\begin{array}{l}\text { The radioactive mineral encrustation on the casings in the } \\
\text { oil producing wells in the Dnieper-Donets depression, Ukraine }\end{array}$ & UKRAINE & $P$ & & S-W-66 \\
\hline Golovko & Natalia & V. & Organic substances and the migratory processes of radionuclides & UKRAINE & $P$ & & S-W-67 \\
\hline Kadatskaya & Olga & V. & Chernobyl contamination as a new geographical factor in Belarus & BELARUS & $P$ & & S-W-68 \\
\hline Kadatsky & Valery & B. & $\begin{array}{l}\text { Re-suspension of the radionuclides in the Belarus soils distant } \\
\text { from the Chernobyl Nuclear Power Plant }\end{array}$ & BELARUS & $P$ & & S-W-69 \\
\hline
\end{tabular}

"Presentation type $(O=$ oral; see program matrix for session number, date, and time. $P=$ poster; see program matrix for session dates) "Poster presentation times ( $S-W=S u n d a y$ - Wednesday; $W-F=$ Wednesday - Friday)

\section{ABBREVIATIONS USED IN THE ABSTRACTS:}

$\begin{array}{ll}\text { a } & \text { year } \\ \mathrm{Bq} & \text { Becquerel } \\ \mathrm{dL} & \text { deciliter } \\ \mathrm{dpm} & \text { disintegrations per minute } \\ \mathrm{dS} & \text { decisiemens } \\ \mathrm{DW} & \text { dry weight } \\ \mathrm{g} & \text { gram } \\ \mathrm{ha} & \text { hectare }\left(10,000 \mathrm{~m}^{2}\right) \\ \mathrm{kg} & \text { kilogram } \\ \mathrm{L} & \text { liter } \\ \mathrm{m} & \text { meter or molal (context-dependent) }\end{array}$

M molar

mg milligram $\left(10^{-3}\right.$ gram)

$\mu \mathrm{g}$ microgram $\left(10^{-6}\right.$ gram $)$

ML megaliter ( $10^{6}$ Liter)

$\mu \mathrm{m} \quad$ micrometer $\left(10^{-6}\right.$ meter $)$

ng nanogram $\left(10^{-9}\right.$ gram)

$\%$ permil (parts per thousand)

pg picogram $\left(10^{-12}\right.$ gram)

rsd relative standard deviation

s second

wk week 


\section{Abstract Title Index}

A Chemical and Mineralogical Reconstruction of Emissions from $\mathrm{Zn}$ Smelters in the Kempen Region (Belgium), Based on Peat Cores .............................................................. 86

A Comparison Of Field And Laboratory Analytical Methods Of Radon-Potential Mapping In Areas With And Without Glacial Drift Coverage ............................................. 89

A Comparison of Regional Geochemical Surveys of Till and Lake Sediment, Labrador, Canada ................................ 4

A Comparison of the Geochemistry of Water Draining from Adits and Tailings Piles in the Coeur d'Alene Mining District: Information for the Geoenvironmental Component of Mineral Deposit Models.

A Geochemical Atlas of the Central Parts of the Barents Region . 76

A Geochemical Investigation of the Water and Sediments of Barber's Pan, North West Province .............................. 46

A Large-Scale Laboratory Experiment to Determine the Mass Transfer of CO2 From a Sandy Soil to Moving Ground Water 16

A New Paleoclimate Indicator Based on AMS 14C Dates of Biogenic Whewellite ................................................... 78

A Review of Sulfate Removal Options from Mine Waters .... 14

A Study of the Analytical Variation of Sampling and Analysis of Stream Sediments from Mining and Milling Contaminated Areas.

A Study of the Rare Earth Elements in Aqueous Carbonate and Chloride Systems

A Survey and Analyses of the $\mathrm{d} 18 \mathrm{O}$ and d13C Composition of Selected Shells from Core Tops at Five Locations in Florida Bay

Acid Buffering Capacity and Metals Mobility in Acid-Impacted Agricultural Soils, San Luis Valley, Colorado ................ 34

Acid/saline Ground Waters in the Southern Yilgarn Craton, Western Australia 30

Adsorption of Metal Cations on Manganese Oxide-Coated Filter Sand-A Novel Method for Water Treatment 91

Afforestation-Induced Enhancement of Soil-Solution Aluminum and Manganese Concentrations in South African Highland Catchments

Allozyme Variation Upstream and Downstream of Metal Contaminants in the Brown Trout (Salmo trutta) and Caddis Fly (Arctopsyche grandis) in Clear Creek, Colorado, USA

Aluminum and Iron Mobility in an Acid Sulfate Environment and Consequences for Local Population-- The Case of the Lower Casamance (Senegal)

An Integrated Environmental Geosciences Project in the Santa Cruz River Drainage Basin, Southern Arizona ...... 77 An Investigation into the Mechanism by Which Synthetic Zeolite Amendments Reduce Soil Phytotoxicity ............ 75

Anthropogenic and Geogenic Sources of Trace Metals in the Environment-A Case Study of Contaminated Soils in the Pezinok-Pernek Region of Malé Karpaty Mountains, Slovakia.

Application of a Three Dimensional Coupled Transport and Equilibrium Chemistry Model to the Fate and Transport of Contaminants in the Konigstein Uranium Mine ....... 101

Application of Exposure Assessment Models to Shipham, Somerset, UK: An Area with Soil Contaminated by $\mathrm{Pb}$ and $\mathrm{Cd}$

Application of Mine Fire Diagnostics ..... 18
Application of the Equilibrium Partitioning Method in Surficial Sediments near a Deepwater Ocean Outfall Off Malabar, Sydney, Australia

Archaeological Bone as Baseline for Present Day Human Exposure 38

Arsenic Exposure in SW England, UK: Significance for Human Health. 43

Assessment of Suitability of Some Disturbed Land for Herb Cultivation 12

Baseline Survey of Air Pollution Impacts on Soil and Water Quality in Mpumalanga Province, South Africa 93

Behavior of Heavy Metals and REE in Acid Mine DrainageImplications for the Behavior of Transuranic Metals ...... 70

Behavior of Polycyclic Aromatic Hydrocarbons in Soil Ecosystems 27

Biodegradation of 14C Labeled Organic Acids and OrganoMetal Complexes in Soil 23

Biogeochemical Heavy Metal Regionalization and Human Risk Assessment . 9

Biogeochemical Mechanisms Influencing Metal Mobility in Natural and Constructed Wetlands ............................... 22

Biogeochemistry of Acid Drainage from Coal Mining Operations in the Witbank Area

Biogeochemistry of Trace Elements in Plants and Soils Around Nasser Lake (Egypt) ................................................. 74

Biotreatment of Metal Mine Waste Waters - Case Histories ... 25

Buffering of Acid Rock Drainage by Silicate Minerals ......... 12

Changes in Urban Geochemistry in Nottingham and Birmingham between 1982 and 1997 39

Characterization of Gypsum Mine Wastelands and Their Rehabilitation

Chemical and Mineralogical Changes Associated With Leachate Production at Kriel Power Station Ash Dam, Mpumalanga, South Africa ....................................... 10

Chernobyl Contamination As A New Geographical Factor In Belarus ................................................................ 4

Chernobyl Nuclides in Soils and Gamma-Dose Rate in Air Of

Belarus

Classifying and Mapping the Sensitivity of South African Highveld Soils to Acidification

Comparative Testing Between Conventional and Microencapsulation Approaches in Controlling Pyrite Oxidation

Comparison of Ground-Water Chemistry from the Carbonate Platform Region of the Ozark Mountains, USA ............. 87

Comparison of the Measured and Modeled Geochemical Composition of a Nevada Pit Lake ............................... 55

Compatibility of Data Derived from Different Selective Extraction Schemes 33

Concentration and Chemical Partitioning of Heavy Metals in Road Dusts and Urban Soils in Hong Kong .................. 54

Contaminant Detection On Soils Using Static SIMS ............ 39

Contaminant Dynamics in Port Jackson Estuary, Sydney, Australia .............................................................. 90

Contamination of Ground Water in Diverse Hydrogeochemical Environments, SE Hungary ........................... 94

Coupling Three Dimensional Transport with GeochemistryMT3D and PHREEQE 101

Crustose Lichens - Capable of Monitoring the Atmospheric Deposition of Trace Elements and Organohalogens? ...... 61

Delineating Risk Areas of Contaminated Ground Water Using Geochemical Databases 90 
Denitrification of Nitrate-Rich Ground Water Entering Verlorenvlei Lake on the West Coast of South Africa ..... 34

Determination Of Lead In Environmental Matrices By Hydride Generation Atomic Fluorescence Spectrometry (HGAFS) 71

Determination of Natural Background Concentrations of Dissolved Components in Water at Mining, Milling, and Smelting Sites ...................................................... 78

Differentiation of Heavy Metals as a Reflection of LandscapeUse Levels

Direct Methods Used for Identification of Heavy Metal Forms 36

Discriminating Between Natural and Anthropogenic Anomalies in the Surficial Environment in Yellowstone National Park, Idaho, Montana, And Wyoming .............. 16 Dispersal of Arsenic by Gold Mining Near Barberton, South Africa

Dispersion and Enrichment of Potentially Toxic Elements in Areas Underlain by Black Shales and Slates in Korea .... 52

Distribution and Origin of Fluoride in Rural Drinking Water Supplies in the Western Bushveld Areas of South Africa 62

Distribution of Metals and Effects on Aquatic Biota in the Upper Stillwater River Basin, Montana ......................... 32

Distribution of Sulfur and Heavy Metals in Podzolized Tills in Northern Finland 7

Distribution of Trace and Major Elements in Surface Sediments from Coatzacoalcos River, Mexico 77

Distribution of Trace Metals in Soils near the Base Metal Smelter at Flin Flon, Manitoba: Natural and Anthropogenic Enrichments from A Remote Single Point Source Area

Ecological Changes in Florida Bay - Can We Tell When It Happened?

Ecological-Biogeochemical Status of the Baikal Region, Russia ....

Effect of Industrial Effluents on Trace Element Mobility in Soil

Effects of Evapoconcentration on Water Quality in Mine Pit Lakes

Emissions of Mercury to the Atmosphere: Natural Sources and Pathways 74

Emissions of Platinum-Group-Elements (PGE) from Automobile Catalytic Converters in Soils Along Highways ........ 81

Environmental and Hydrogeological Problems Caused by Overexploitation of Geothermal Ground Water in Coastal Cities of South-Eastern China: A Case Study in Fuzhou Basin

Environmental Applications of the Regional Geochemical Mapping of Soils and Stream Sediments in South

Africa 18

Environmental Geochemical Features in the Coal Mine

Areas in China ............................................................ 99

Environmental Geochemical Mapping in Sardinia (Italy) ..... 19

Environmental Geochemical Mapping in the Ukraine ........... 46

Environmental Geochemistry and Mercury Speciation of Abandoned Mercury Mines in Southwestern Alaska ...... 31

Environmental Geochemistry in the Surroundings of the

Central Waste Deposit of Berlin ................................. 12

Environmental Geochemistry of Boron ............................... 66

Environmental Geochemistry of Gold Deposits in the Mother

Lode Belt, California
Environmental Geochemistry of Mercury Deposits in the Coast Range Mercury Belt, California 78

Environmental Geochemistry of Rare Earth Elements in a Typical Landscape in Jiangxi, Southern China ............... 26

Environmental Geochemistry of Rare Earth Elements in Main

Type Soils in China ................................................. 95

Environmental Geochemistry: A Vital Component of the

U. S. Geological Survey Mineral Resources Program ..... 32

Environmental Impact of Phosphogypsum Use in

Agriculture 75

Environmental Impacts of Lignite Opencast Mining Areas in Eastern Germany ......................................................... 27

Environmental Monitoring of Geochemical Changes in Ash-

Dumps and Silage-Heaps .......................................... 42

Environmental Studies of Mineral Deposits in Alaska .......... 31

Establishing Pre-Disturbance Water Quality Standards in Areas of Natural Acid-Metal Contamination-Upper

Alamosa River, Southern Colorado

Evaluation of Baseline Soil Geochemistry in Support of Environmental Health Studies in the Rocky Mountain Region 11

Exposure of Children to Lead in the Home Environment-A

Comparative Study in Shanghai and Birmingham ......... 96

Exposure to Platinum from Vehicle Catalytic Converters and

Possible Health Implications ....................................... 23

Fine Dust (PM10) Composition in a Major City: Mineralogy, Lead-Isotope and PAH-Composition in Vienna .............. 48

Formation of Gossan and Oxidation of Sulfide Ores as Analogs of Oxidation of Tailings Piles

Geochemical and Lead-Isotopic Studies of the Environmental Effect of Mining at Summitville, Colorado .................. 17

Geochemical Assessment of Passive Treatment Methods for Acid Mine Waters from a Flooded Uranium Mine ......... 19

Geochemical Characterization of a Fluvial Tailings Deposit Along the Arkansas River, Colorado, USA ................... 86

Geochemical Factors Controlling Infantile Exposure to Cerium and its Implications to the Aetiology of Endomyocardial Fibrosis in Uganda

Geochemical Mapping in the New Federal States of Germany 11

Geochemical Transport Modeling Of Mine Tailings Pore

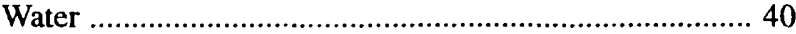

Geochemistry and Human Selenium Imbalances in China ..... 24

Geochemistry and Water Quality Prediction for Skarn

Deposits in the New World Mining District

Geochemistry of Arsenic and Fluorine in Shallow Ground Water: Eastern Owens Lake, California ....................... 53

Geochemistry of Coals Causing Arsenism in Southwest China ................................................................. 10

Geochemistry of Heavy Metals Derived from Sulfide Gold Minerals in the Marmato District, Colombia ................. 72

Geochemistry of Mercury and Trace Elements in OrganicRich Sediments and Vegetation from the Everglades, South Florida

Geochemistry of Overbank Sediments in Belgium and Luxembourg: A Way to Assess Environmental Pollution ......... 93

Geoenvironmental Assessment of Montana-Potential for Acidic, Metal-Rich Drainage .................................... 52

Geology and Geochemistry of Water and Stream-Sediment Samples of the Upper Pecos River, from the Southern Pecos Wilderness to Brantley Dam, North of Carlsbad, Eastern New Mexico 
Ground Truth Versus GIS Model-The Ground-Water Quality of the Vistula River Floodplain near the City Of Plock (Poland) ................................................................ 57

Ground-Water Flow System Estimated by Water Quality ...... 89

Heavy Metal Contamination in Dusts and Stream Sediments in the Taejon Area, Korea .......................................... 44

Heavy Metal Distribution and Environmental Status of Doon

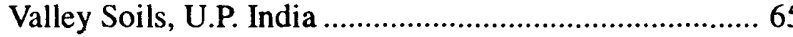

Heavy Metals as Indicators of Antropogenic Pollution of Bottom Sediments in Neva Bay.

Heavy Metals in Humus and Organogenous Layers with Different Human Activities

Heavy Metals in Soils of the Sabana de Bogotá, Colombia ... 29

High Resolution Baseline Mapping of Hydrochemical

Processes and Their Correlation with Geochemical Anomalies and Anthropogenic Activities: Wales and the Welsh Borders.

Hydrogeochemical Controls on Trace Element Release from the Penn Mine Base Metal Slag Dump, Calaveras County, California-Linking Field, Laboratory, and Geochemical Modeling Studies

Hydrological Explanation of the Heavy Metals Concentration in the Wyszogrod Island (Vistula River near Plock, Poland) 100

Identification and Characterization of Mine Effluent in Streams of the Colorado Mineral Belt- The Snake River,

Montezuma Mining District 72

Identification of Arsenic-Rich Ground Water Using Geochemical Signatures and Geophysical Log Analysis, Albuquerque, New Mexico

Impact of the $\mathrm{Pb}-\mathrm{Zn}$ Industry on the Contamination of the Przemsza River, Upper Silesia, Poland 36

Incidental Amendment of Mercury to Agricultural Fields by Turbid Irrigation Waters and Natural Floods in Nevada and Oregon

Inductively Coupled Plasma - Atomic Emission Spectrometry Used in Analysis of Pollutants from an Area With Non-

Ferrous Extraction and Ore-Processing .... 94

Influence of Bicarbonate on Pyrite Oxidation 22

In-Situ Alteration of Minerals by Acidic Ground Water

Resulting from Mining Activities 55

Integrating GIS and Multivariate Statistics in Environmental Geochemistry. 82

Interdisciplinary Training Modules in Mining and the Environment-Case Study On The 100

Investigation of the Environmental Impact from Industry Wastes Deposited in an Urban Area of Falun, Sweden ... 55

Iron Deposition and Magnetic Susceptibility of Forest Soils in Katowice Province 88

Isotopic and Chemical Compositions of Rain and Snow Precipitation at Bologna, Italy 17

Laboratory Leaching Behavior of an Arkansas River Fluvial

Tailings Deposit, Leadville, Colorado .......................... 40

Laboratory Measurements of the Absorption and Oxidation of

Sulfur Dioxide by Soil Surfaces 79

Lacustrine Records of Heavy Metal Pollution-Problems of

Dating 81

Leaching of Contaminants from an Aggregate ..................... 35

Lead and Zinc Contamination of Sediments in Zoar Vlei, Cape Peninsula, South Africa ...................................... 75

Lead in the Environment, China ..................................... 98
Lead Isotope Anomalies in Maar Lake Sediments - Indications for Extensive Lead Mining in the Northwestern Eifel (Germany) During the Time of the Roman Empire ......... 81

Lithogeochemical Map of the Chesapeake Bay WatershedAn Example of Usable Repackaging of Traditional Geologic Information

Low-Water Sediment in Rivers of Belarus: Origin, Mineralogical and Geochemical Composition, Potential Use For Environmental Assessment ............................................ 79

Management System (SEMS) - Carletonville Gold Mining Area as a Pilot Study.

Manifold Heavy Metal and As Contamination by a German $\mathrm{Zn}$-Pb Deposit With a Two-Thousand Year Mining History 10

Mapping Chemical Contaminants in Estuarine and Coastal Marine Sediments: New Approaches to Validating and Using Historical Data .

Mass-Balance Study of the Flin Flon Smelter Emissions: Calculations on Metals in Humus in the Flin Flon-Snow Lake Region, Manitoba and Saskatchewan

Measurement and Simulation of Pyrite Oxidation in the Blasted Rock of an Open-Pit Mine.

Measurement of Gas Exchange Processes Between Soils and the Atmosphere and Applications in Environmental and Exploration Geochemistry .

Mercury Occurrence, Transport, and Speciation in the Sacramento River Basin, California ...................................... 21

Mercury Speciation In Soils And Vegetation, Southwest Alaska .

Metal Fluxes and Accumulation in Lakes of Latvia .............. 45

Metal Release and Recolonization Characteristics of Tailings in a Marine Environment - A Laboratory Study and Site Demonstration 50

Metal Removal Efficiencies of Substrates for Treating Acid Mine Drainage of the Dalsung Mine, Korea. ................. 17

Metals in an Estuarine System: Sources and Sinks ............... 15

Methods and Evaluation Models for Standardized Risk Assessment of Gold Mining Waste Sites in South Africa. 99

Methods of Monitoring of Environmental Health-With Special Reference to Regions in Ecological Crisis .......... 58

Migration of Heavy Metals Away from Landfills in Leachate: Observations at the Near- and Far-Field Scale ............... 13

Mineral Crusts or Microbial Mats? Alteration of Surficial Mine Tailings in the Leadville District, Colorado ........... 87

Mobilization and Attenuation of Metals Downstream of a Base-Metal Mining Site in the Mátra Mountains, Northeastern Hungary

Mobilization of Lead from Maternal Skeleton during Pregnancy

Modern Shallow-Water Fe-Mn Concretions as an Indicator of the Contamination of Marine Environments: A New Type of Marine Environmental Geochemical Monitoring.

Moisture and Salinity Limits on Pyrite Oxidation in SemiArid Climates

Monitoring Marine Pollution and Determining Palaeoclimate: The Application of Laser Ablation ICP-MS Studies to Marine Bivalve Mollusks ........................................... 71

Multimedia Environmental Geochemical Mapping Using Field Portable X-Ray Fluorescence 
Multistage Reflectance Spectroscopic Analyses of Central German Lignite Overburden Dumps (First Results) ........ 49

Natural Acid Drainage Associated with Shale-Hosted Ag$\mathrm{Pb}-\mathrm{Zn}$ Massive Sulfide Deposits in the Brooks Range, Northern Alaska, USA

Natural Analogue for Bedrock Pollution: Environmental Impact of Ni-Cu-Zn-Rich Black Shales at Talvivaara in Finland. 56

Natural Arsenic In Triassic Sediments As Source Of Drinking Water Contamination In Bavaria, Germany ...................... 35

NEOCHIM - An Electrogeochemical Method for Environmental Applications .......................................... 53

On Determination of Heavy Metal Fractions in Estuarine Sediments

Ore Fields, Deposits, and Zones of Deep Faults As Probable Geo-Pathogenic Biogeochemical Provinces and Belts ... 47

Organic Substances in Migratory Processes of Radionuclides 28

Organometal(oid) Species in Geochemical Exploration:

Preliminary Qualitative Results ...................................... 36

Perched Water Zones in Arid Environments: Geochemical Constraints on Hydrological Modeling for High-Level

Radioactive Waste Disposal 91

Pesticide Adsorption onto Aquifer Sediments 73

Plant-Soil Relationships in the Serpentinite Screes of Mt.

Prinzera, Northern Apennines, Italy ................................. 20

Pollution of Czech Freshwaters by Trace Elements ................ 58

Pollution of Sediments, Soils, and Plants by Thallium .............. 6

Possibility of Geological Disposal of CO2: Results from

Geochemical Modeling .................................................. 97

Preservation of Arsenic Species in Natural Waters ................. 33

'rinciples of Landscape Geochemical Map Composition and

Landscape Geochemical Zonality of Aral Sea Rim

Purifying Toxic Metal Contaminated Ground Water by

Chitosan in Partially Converted Crab Shell

Quantification of Environmental Exposure Vectors by

Geochemical Methods

Radiogeochemical Mapping in the Ignalina Nuclear Power

Plant Region (Bottom Sediments and Soils)

Radiometric Risk Mapping Using Existing Geoscience Data

Sets

Reactions and Transport of Copper in Headwater Streams

Receiving Acid Rock Drainage 6

Recent (1930's) Natural Acidification and Fish Kill in a Lake That Was an Important Food Source to the Population of Akulivik, Northern Québec. 15

Recovery of Brown Trout (Salmo Trutta) and Brook Trout (Salvelinus Fontinalis) Populations in the Eagle River, Colorado, U.S.A., During and Following CERCLA Recovery Actions

Regression Methods in Bedrock Ground-Water Composition

Estimation from Hydrogeological Parameters 56

Rehabilitation-Induced Vegetation Progression at a Gypsum Mine in Western Rajasthan-Analytical Approaches and Empirical Evidence 50

Relationship Between Alzheimer's Disease and Aluminum Speciation in Drinking Water: A Case-Control Study in Saguenay-Lac-St-Jean, Quebec (Image Project) .............. 27 emediation of High-Fluoride Ground Waters from Arid Regions Using Heat-Treated Soils: A Column Experiment Study in Xinzhou, China...
Resuspension Of Radionuclides In Belarus Soils Distant From The Chernobyl Nuclear Power Plant ...................... 42

Risk Assessment of Ecosystem Buffering to Acid Input in Russia 9

Risk Assessment Related to Metals: The Role of the Geochemist 92

Small Scale Spatial Relationships Between Geology, Stream Water Chemistry and Stream Sediment Chemistry in Small Upland Catchments

Soil Chemical Patterns Possibly Linked to Mseleni Joint Disease Among Rural Inhabitants in Northern Kwazulu-

Natal, South Africa

Soil Parameters as a Basis for the Assessment of Trace Metal Pollution 41

Soil $\mathrm{Pb}, \mathrm{Zn}$, and $\mathrm{Cd}$ in Metropolitan New Orleans-Their Geochemical Characterization and Association ............... 64

Solid Phase AAS - A New Old Technique: First Results with Environmental Material

Solubility of Heavy Metals in Relation to Geological Context: A Theoretical Approach

Solubilization Of Heavy Metals (Cd, Ni, Pb) During Percolation Of The Chelating Agent EDTA Through Polluted Soils And Sediments ..... 43

Some Approaches to the Biogeochemical Study of Contaminated River Ecosystems

Some Methods for Estimating Phytoavailable Cadmium in Prairie Soils

Some Peculiarities of Chemical Element Bioaccumulation in Different Environmental Samples .................................. 83

Source Attribution Of Lead Particles In Pre- And Contaminated Post-Lead Paint Abatement Interior Dusts ............. 39

Source Chemistry and Characteristics of Intermittent Stream Waters Having Low $\mathrm{pH}$ and Elevated Metal Concentrations, Patagonia Mountains, Santa Cruz County, Arizona 30

Stable Isotope Characteristics of Waters Draining Massive Sulfide Deposits in the Eastern United States ................. 82

Sulfate Adsorption Model for Predicting Soil Acidification .. 26

Temporal and Spatial Variations in the Chemistry of Ochres Derived from an Abandoned Metalliferous Mine 25

Temporal Variability in the Geochemistry of Waters from Abandoned Coal Mines, County Durham, UK

Temporal Variation in the Concentrations and Speciation of Metals in Peru Creek, Summit County, Colorado ........... 88

Testing Contaminant Mobility in Soils and Waste Materials .. 37 Textural Analysis and its Importance as Indicator of Energy Levels in Environmental Geochemistry ......................... 16

The "Kola Ecogeochemistry" Project ....................................... 76

The Application of Geochemical Data to Environmental Concerns in the Minas Gerais State, Brazil .................... 18

The Application of Regional Geochemical Data in an Environmental Study ................................................................... 54

The Behavior of $\mathrm{Cd}$ and $\mathrm{Hg}$ During Weathering of SphaleriteEnvironmental Implications ............................................ 25

The Behavior of Rocket-Fuel Components in Soil and Plants in Kazakhstan and Altay Region in Russia ....................... 43

The Biogeochemistry of Sulfur in the Freshwater Florida Everglades-Sources, Cycling, and Relation to Mercury Methylation

The Connection of Some Heavy Metals With a Magnetic Phase in Fly Ashes from Two Polish Thermal Power Plants 
The Development of a Biological Toxicity Based Test for Water Quality.

The Distribution of Natural Radioelements in Ground Waters and Post-Cretaceous Sediments from the Southern Mediterranean Margin 84

The Effects of Glacial Dispersal and Glacial Process on Till Geochemistry, Labrador, Canada . 45

The Experience and Results of the Disposal of Liquid Radioactive Waste (LRW) on a Siberian Chemical Industrial Plant

The Influence of Mine-Drainage Formation on the Geochemical and Hydrogeological State of Environment in Estonia

The Investigation of Redox Reactions and Adsorption of Chromium in Soils 58

The Radioactive Mineral Encrustation on the Casings in the Oil-Producing Wells in the Dnieper-Donets Depression, Ukraine 83

The Response of the Interlayering of Clay Minerals to the Mobility of Aluminum in Acidified Podzols 73

The Role of Environmental Geochemistry in the U.S. Geological Survey 51

The South African Environmental 100

The Spatial Reliability of Geochemical Maps 64

The Use of Holocene Floodplain Sedimentary Sequences for Geochemical Mapping in the Yorkshire Ouse River Basin, UK. 38

The Use of Sedimentation Field Flow Fractionation - Inductively Coupled Plasma Mass Spectrometry for the Chemical Characterization of Suspended Particulate Matter in Environmental Hydrologic Systems

The Use of Two Leaches in Environmental Geochemical Mapping to Assess Concentration Levels and Mobilities of Elements in Soils

The Utilization of High Spectral Resolution Imagery and Field Spectra for the Detection and Monitoring of Mining Sites

Three-Dimensional Nanocrystalline Networks Limit Limestone Drain Remediation: A Role for Environmental Mineralogy.

Towards a Contaminant Model for Port Jackson, Sydney's Main Estuary 11

Trace Element Distribution in Soils and Factors Affecting Metal Uptake By Plants in the Contaminated Floodplain of the Svisloch River, Belarus.

Trace Elements in the Kuskokwim River, Alaska 95

Trace Metal Adsorption onto Schwertmannite (Iron Oxyhydroxysulfate) in Acid Mine Drainage Systems .... 96

Trace-Element Contamination in The Environment of Recife Metropolitan Area, Pernambuco, Brazil....

Unique Ground Water (Karst) Monitoring System as an Important Tool of Drinking Water Protection in Austria . 49

Unraveling the Degree and the History of Environmental Pollution Based on the Evaluation of Vertical Geochemical Profiles in Overbank Sediments

Uptake of Trace Elements by Nutrient Plants from Soils Contaminated by Mining Activities in SW-Germany and North-Central Mexico

Uranium and Uranium Isotopes as Tracers of Nutrient Addition: A Case Study in South Florida

Uses of Chemical Speciation for Impact Evaluation and Remediation of Mining Waste
Variable Geochemical Responses to Water-Rock Interactions at Two Undisturbed Zn-Pb Massive Sulfide Deposits, Bathurst Mining Camp, N.B., Canada

Variations in Chemical and Bacterial Species of Acid Mine Drainage Affecting the Snow Fork Drainage Basin, Ohio-The Esco \#40 Underground Mine

Vehicle Related Emissions of Heavy Metals and Platinum Group Elements in the Urban Environment- Examples from Birmingham, UK

Weathering and Colloid Mobility as Factors Influencing the Migration of Radioactive Elements at Steenkampskraal Mine in the Northern Cape Province, South Africa 28

What Is Background? A Statistical Approach, Introduced with Data for the Baltic Sea

Zambian Copperbelt, Central Africa. 100 


\section{Reactions and Transport of Copper in Headwater Streams Receiving Acid Rock Drainage}

AMACHER, M.C. ${ }^{1}$ KOTUBY-AMACHER, J. ${ }^{2}$, and BROWN, R.W.' ${ }^{\prime} U S D A$, Forest Service, 860 North 1200 East, Logan, UT 84321, USA

${ }^{2}$ Utah State University, Logan, UT, USA

Acid rock drainage (ARD) from Fisher Mountain near Cooke City, Montana has severely contaminated Fisher Creek, a headwater stream of the Clark's Fork of the Yellowstone River. The $\mathrm{pH}$ of Fisher Creek increases from 3.0 at the Glengarry Mine adit to near neutral about $4500 \mathrm{~m}$ downstream. Tributaries in the upper part of the watershed dilute ARD from the Glengarry Mine, but because they flow through acidic igneous rock, they have low alkalinity levels and do not increase stream $\mathrm{pH}$. Tributaries in the lower part of the watershed flow through more calcareous rock and add sufficient alkalinity to increase the $\mathrm{pH}$ of Fisher Creek to near neutral levels. Ferrihydrite precipitates in the upper part of the stream but particulate ferrihydrite and ferrihydrite-coated sediment fines are transported downstream during periods of high flow resulting in a high iron oxide content of sediments along a $4500 \mathrm{~m}$ length of stream. Hydrologic mass balance calculations indicate that downstream decreases in $\mathrm{Cu}$ concentrations in the upper part of Fisher Creek result from dilution by tributaries. Further downstream as tributaries add some alkalinity and the $\mathrm{pH}$ .ncreases to near neutral levels, decreases in $\mathrm{Cu}$ concentrations in Fisher Creek are the result of adsorption by ferrihydrite in streambed sediments. These decreases were predicted using the diffuse-layer adsorption model, a surface-complexation model included in the equilibrium chemical speciation computer program MINTEQA2. The $\mathrm{Cu}$ content of the ferrihydrite fraction of Fisher Creek sediment increased as $\mathrm{pH}$ increased over the stream reach where $\mathrm{Cu}$ adsorption was predicted to occur.

\section{Temporal Variability in the Geochemistry of Waters from Abandoned Coal Mines, County Durham, UK}

\author{
ANDER, E.L.', THORNTON, I.', FARAGO, M.E.', and \\ RICHARDS, D.G. ${ }^{2}$ \\ 'Environmental Geochemistry Research Group, Centre for \\ Environmental Technology, Imperial College of Science, \\ Technology \& Medicine, Prince Consort Road, London, SW7 2BP, \\ $U K$ \\ ${ }^{2} R T Z$ Technical Services Ltd., PO Box 50, Castlemead, Lower \\ Castle Street, Bristol, BS99 7YR, UK
}

The County Durham coalfield, NE England, has a long istory of subsurface mining of Carboniferous coal. The secent closure of all remaining deep mines in this coalfield has raised the possibility that ground-water withdrawal (for mine dewatering) may be discontinued. Research into the hydrogeology of the coal measures by other workers has established that much of the rebounded ground water would drain into the river Wear, a regionally important watercourse, directly or via tributaries. The occurrence of dissolved pyrite oxidation products in flooded mine workings has been widely studied by many other researchers. When such ground water enters surface water courses the precipitation of ochres and some reduction in the $\mathrm{pH}$ of waters in the river Wear catchment may be expected. This study aims to assess the potential occurrence and dispersion of elements, some of which may be toxic, in tributary waters of the river Wear. Uncontrolled mine and spoil heap drainages from previously abandoned workings in the west of County Durham have provided eight points of discharge and three downstream traverses. Sampling was undertaken at these sites on several occasions, in varying hydrological conditions, and was followed by multielement analyses of water, suspended sediment and stream sediment. The results have shown that there is much chemical variability between deep mine and spoil heap issues. Temporal chemical variations of up to several orders of magnitude (examples of value ranges observed at one site: $\mathrm{pH}$ 3.7-5.8, Fe 8,110-69,400 $\mu \mathrm{g} \mathrm{L}^{-1}$, Mn 1,600-20,300 $\mathrm{g} \mathrm{L}^{-1}$ and $\mathrm{Al}$ $820-74,400 \mu \mathrm{g} \mathrm{L}^{-1}$ ) were observed at some sites at the point of emergence and marked changes were also observed in downstream hydrogeochemistry seasonally. The differences are such that they strongly alter the potential toxicity of the waters and the nature of the minerals precipitating from them. These differences have been attributed to the differing hydrological behavior of the mine spoil heaps and deep mines and to seasonal effects.

\section{Pollution of Sediments, Soils, and Plants by Thallium}

ASAMI, Teruo, MIZUI, Chizuru, NOGAMI, Naoko, and KUBOTA, Masatsugu

School of Agriculture., Ibaraki Univ., Ami, Ibaraki 300-03, Japan

Thallium (Tl) is a highly toxic element. Pollution from $\mathrm{Tl}$ is thought to be restricted to places such as non-ferrous metal mines, smelters, and factories using $\mathrm{Tl}$. However, since the discovery of high-temperature superconducting compounds in the system $\mathrm{Tl}-\mathrm{Ca}-\mathrm{Ba}-\mathrm{Cu}-\mathrm{O}, \mathrm{Tl}$ has attracted greater attention as a potential pollutant on a large scale in the future. Therefore, we established a method for determining $\mathrm{Tl}$ content in sediments, soil, and plants, and determined concentrations of $\mathrm{Tl}$ and other harmful metals in sediments and soils of Japan. Effects of $\mathrm{Tl}$ on some crops were also studied.

Method of $\mathrm{Tl}$ determination: The determination of $\mathrm{Tl}$ in sediment and soil by FAAS, involving extraction of $\mathrm{Tl}$ from $5 \mathrm{~g}$ of sediment or soil by digestion with $\mathrm{HCIO}_{4}-\mathrm{HNO}_{3}$ followed by separation of extracted $\mathrm{Tl}$ into $5 \mathrm{ml}$ of diisopropylether from $\mathrm{HBr}$ solution including $\mathrm{Ce}\left(\mathrm{SO}_{4}\right)_{2}$. $\mathrm{Tl}$ in the organic phase is determined by direct aspiration into the AAS. The geometric mean (range) of 18 Japanese unpolluted surface soils was $0.31(0.10-0.56) \mathrm{mg} \mathrm{Tl} \mathrm{kg}^{-1}$ dry weight (DW) (Fresenius J. Anal. Chem., 356: 348-351, 
1996). $\mathrm{Tl}$ in plant material was analyzed by nearly the same method.

Pollution of sediments and soils with $\mathrm{Tl}$ and other harmful metals: As an example, pollution of sediment and soil by $\mathrm{Tl}$ and other harmful metals near the Hosokura Mine and Smelter will be reported. This mine and smelter had been producing large amounts of $\mathrm{Pb}, \mathrm{Zn}, \mathrm{Cd}$, and $\mathrm{Ag}$, and smaller amounts of $\mathrm{Cu}, \mathrm{Sb}, \mathrm{Tl}$, and $\mathrm{Bi}$. The geometric mean (range) of $\mathrm{Tl}$ content in 10 sediments was 17.5 (4.81-79.9) $\mathrm{mg} \mathrm{Tl} \mathrm{kg}{ }^{-1} \mathrm{DW}$. The amounts of $\mathrm{Tl}$ are high near the mine and smelter and decrease downstream. The geometric mean (range) of Tl concentration in 19 soils was not so high, and was $0.58(0.26-2.39) \mathrm{mg} \mathrm{Tl} \mathrm{kg}^{-1} \mathrm{DW}$. Correlation coefficients between the amounts of $\mathrm{Tl}$ and the other metals are high both in the sediments and the soils.

Effects of Tl on crops: Growth of 3 kinds of crops was retarded remarkably by $\mathrm{Tl}$ addition to culture solution. $\mathrm{Tl}$ in the culture solution was absorbed easily by these crops. For example, the shoot and the root of Brassica campestris in 1

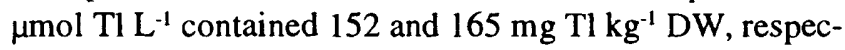
tively. The $\mathrm{Tl}$ was not accumulated in the root and easily translocated to the shoot.

Since $\mathrm{Tl}$ is easily absorbed by crops and is highly toxic to living things including human beings, it will be necessary to investigate the state of pollution and behavior of $\mathrm{Tl}$ in the environment.

\section{Environmental Geochemistry of Gold Deposits in the Mother Lode Belt, California}

ASHLEY, Roger P.

U.S. Geological Survey, 345 Middlefield Road, Menlo Park, CA 94025, USA

The Mother Lode belt is a vein system 1-5 km wide that follows the Melones fault zone, a major regional structure in the Sierra Nevada foothills, for $200 \mathrm{~km}$. Lode mining began in 1849 and has continued intermittently to the present, resulting in total production of about $440 \mathrm{t}$ of gold. The deposits are classified as low-sulfide gold-quartz veins. They formed 110-130 ma ago, after prograde metamorphism and penetrative deformation, from upward-moving $\mathrm{CO}_{2}$ bearing fluids. In the northern half of the belt most ore bodies are in quartz veins that contain free gold, pyrite, arsenopyrite, and minor base metal sulfides. Sulfide contents are less than 2 percent. Carbonate-altered greenstone and slate containing as much as 10 percent pyrite and arsenopyrite form substantial low-grade ore bodies. In the southern half of the belt, ore bodies are mainly disseminated gold and pyrite, commonly with tellurides, in carbonatealtered serpentine, greenstone, and slate. Base metal sulfides and sulfosalts are scarce, and arsenopyrite is rare or absent, but altered serpentine contains minor niccolite, gersdorffite, and millerite.

The main environmental concern is $\mathrm{Hg}$ and soluble $\mathrm{As}$ compounds in mill tailings. The ores have elevated $\mathrm{Hg}$ levels $\left(0.1-1 \mathrm{mg} \mathrm{kg}^{-1}\right)$, and additional $\mathrm{Hg}$ has been introduced in ore processing. Concentrations of As are com- monly $100-1000 \mathrm{mg} \mathrm{kg}^{-1}$ in tailings, and $100-1000 \mu \mathrm{g} \mathrm{kg}^{-1}$ in mine drainage and mine pit waters. Although the ores contain carbonate minerals and have low sulfide contents, locally sulfide-concentrate and ore stockpiles produce acid drainage. Copper, $\mathrm{Pb}, \mathrm{Zn}, \mathrm{Te}, \mathrm{Sb}, \mathrm{Tl}$, and locally $\mathrm{Mo}$ and $\mathrm{W}$ are enriched in the ores, but their abundances are generally relatively low.

\section{Measurement and Simulation of Pyrite Oxidation in the Blasted Rock of an Open- Pit Mine}

\author{
ATKINS, David A., COOK, Terri L., KEMPTON, J. Houston \\ PTI Environmental Services, 4940 Pearl East Circle, Suite 300, \\ Boulder, CO 80301, USA
}

Current open-pit mining practices leave large areas of blasted rock in place in the walls and benches of the mine pit. Predictions of long-term releases of acid from sulfidebearing rock in these walls and benches require accurate values for pyrite oxidation rates under field conditions, but these rates cannot be measured by methods that have been used traditionally for tailings and waste rock. To assess potential acid generation from exposed blasted rock in openpit mines, in situ sulfide oxidation rates were measured in waste-rock and sulfide-ore piles and mine pit benches by measuring the rate of decrease in the oxygen content of a chamber sealed to the rock surface, and a corresponding oxidation rate was calculated. Upon completion of the tests, bulk samples of the rock were analyzed for sulfide content. Results indicate that oxidation rates are correlated more strongly to the material type and its associated permeability to oxygen than to sulfide content. Oxygen consumption rates were approximately 800 moles $\mathrm{O}_{2}\left(\mathrm{~m}^{2} \mathrm{a}\right)^{-1}$ in the highly permeable sulfide-ore pile, 400 moles $\mathrm{O}_{2}\left(\mathrm{~m}^{2} \mathrm{a}\right)^{-1}$ in the waste-rock pile, and 40 moles $\mathrm{O}_{2}\left(\mathrm{~m}^{2} \mathrm{a}\right)^{-1}$ in the low-permeability pit bench material. Measurements of physical parameters that affect oxidation rate (sulfide content, permeability/porosity, and fragment size distribution of the rock matrix), were incorporated into a diffusion-limited sulfide oxidation model. Model results correlated well with the field measurements, indicating that the model can accurately predict long-term sulfide mineral oxidation and acid release in sulfide-bearing rock piles and pit benches.

\section{Distribution of Sulfur and Heavy Metals in Podzolized Tills in Northern Finland}

\section{$\ddot{A} Y R \ddot{A} S, M .^{\prime}$, and R̈̈ISÄNEN, M. L. ${ }^{2}$ ${ }^{\prime}$ Geological Survey of Finland, Box 77, 96101 Rovaniemi, Finland ${ }^{2}$ Geological Survey of Finland, Box 1237, 70211 Kuopio, Finland}

In 1992, about 35 podzolized till profiles were sampled in the study line from southwestern Finnish Lapland to northernmost Finnish Lapland. Samples were collected from the eluvial, illuvial and transitional zone layers and parent tills up to one meter. Air-dried, sieved samples of the $<0.064$ 
$\mathrm{mm}$ (fine) and $<2.0 \mathrm{~mm}$ (coarse) were analyzed with the hot aqua regia extraction method by using ICP-AES at the Chemical Lab of the GSF in Rovaniemi. Total concentrations of the main elements were determined by XRF and total $\mathrm{C}$ concentrations by a carbon analyzer and the quantity of humidity and crystalline water by a water analyzer at the Chemical Lab of the GSF in Espoo. In general, element concentrations and distributions varied from profile to profile, particularly from podzol layers downwards to the parent till. Indisputably, this is due to the geochemical variation of tills and the variation in the intensity of podzolization along the study line. Mean and median concentrations of $\mathrm{S}$ and heavy metals were markedly higher in the $<0.06 \mathrm{~mm}$ fraction than in the $<2.0 \mathrm{~mm}$ fraction of all soil layers. The contrast was greater for sulfur and heavy metals than for the main elements. Sulfur was markedly enriched in the illuvial and transitional zone layers compared to its concentration in the parent till. The metals were sporadically enriched in the illuvial layer. The distribution pattern is rather due to the differences in the podzolization than to the long-range transported sulfuric and metallic aerosol.

\section{Mercury Speciation In Soils And Vegetation, Southwest Alaska}

\author{
BAILEY, Elizabeth A.', HINES, Mark E. ${ }^{2}$, GRAY, John E. ${ }^{3}$ \\ 'U.S. Geological Survey, 4200 University Drive, Anchorage, AK \\ 99508, USA \\ Biological Sciences Department, University of Alaska Anchorage, \\ Anchorage, AK 99508, USA \\ ${ }^{3}$ U.S. Geological Survey, P.O. Box 25046, MS 973, Denver \\ JlFederal Center, Denver, CO 80225, USA
}

To characterize the distribution of mercury species in soils and vegetation and the geochemical controls on the behavior of $\mathrm{Hg}$ in the terrestrial environment, we measured total $\mathrm{Hg}$ and methylmercury concentrations in vegetation and total $\mathrm{Hg}$, methylmercury, $\mathrm{Hg}^{2+}$, and $\mathrm{Hg}^{0}$ in soils near three abandoned $\mathrm{Hg}$ mines (Red Devil, Cinnabar Creek, and Red Top) in southwest Alaska. Total Hg and methylmercury in all samples collected near the mines are elevated over those in regional background samples. Vegetation contains as much as $970 \mu \mathrm{g} \mathrm{kg}^{-1}$ total $\mathrm{Hg}$, whereas background samples contain no more than $190 \mu \mathrm{g} \mathrm{kg}^{-1}$. Methylmercury levels are as high as $37 \mu \mathrm{g} \mathrm{kg}^{-1}$ in mine site vegetation samples but background samples contain no more than $1.5 \mu \mathrm{g} \mathrm{kg}^{-1}$. A subset of the vegetation samples was separated into leaf tissue, stem tissue, and flowering/fruiting body tissue and analyzed individually for total $\mathrm{Hg}$. Leaf tissues consistently exhibited higher concentrations of $\mathrm{Hg}$ than either the stem or fruiting body tissues. Soil samples collected at the mine sites contain as much as $5,326 \mu \mathrm{g} \mathrm{g}^{-1}$ total $\mathrm{Hg}$ and $133 \mu \mathrm{g}$ $\mathrm{kg}^{-1}$ methylmercury, whereas background samples contain no more than $3.7 \mu \mathrm{g} \mathrm{g}^{-1}$ total $\mathrm{Hg}$ and $9.2 \mu \mathrm{g} \mathrm{kg}^{-1}$ methylmercury. Jivalent and monovalent $\mathrm{Hg}$ were measured in a subset of the soil samples collected and in almost all samples contain $\mathrm{Hg}^{2+}$ and $\mathrm{Hg}^{0}$ elevated over background samples. Soil samples collected from the mines contain as much as 484
$\mathrm{Hg}^{2+}$, background samples contain no more than $0.37 \mu \mathrm{g} \mathrm{g}^{-1}$ $\mathrm{Hg}^{2+}$. Mine site soils exhibit $\mathrm{Hg}^{0}$ emission rates up to 8.80 $\mathrm{ng} \mathrm{g}^{-1} \mathrm{hr}^{-1}$ whereas fluxes from background soil samples are generally less than the detection limit of $0.02 \mathrm{ng} \mathrm{g}^{-1} \mathrm{hr}^{-1}$. Although samples from the mines have significantly elevated levels of all $\mathrm{Hg}$ species measured when compared with regional background sites, our data show that the ratio of methylmercury to total $\mathrm{Hg}$ is higher in the background sites. That is, $\mathrm{Hg}$ contaminated soils may not accumulate significantly higher levels of methylmercury. This is consistent with $\mathrm{Hg}$ data from aquatic environments but little is understood about the geochemical cycling of methylmercury in terrestrial ecosystems. The elevated levels of $\mathrm{Hg}^{2+}$ found in the mine soils may play a role in controlling methylmercury concentrations by way of an enzyme catalyzed (organomercurial lyase) microbial demethylation reaction that produces $\mathrm{Hg}^{2+}$ thus preventing high concentrations of methylmercury from accumulating in these soils. The $\mathrm{Hg}^{2+}$ produced by demethylation may be further reduced to $\mathrm{Hg}^{0}$ by another enzyme catalyzed (mercuric reductase) microbial reaction that is also controlled by the presence of $\mathrm{Hg}^{2+}$. When $\mathrm{Hg}^{2+}$ is present in low concentrations, such as in the regional background sites, the enzymes that catalyze microbial demethylation and reduction are not synthesized and methylmercury may not accumulate. It is assumed that most $\mathrm{Hg}$ found in plants comes from foliar absorption of $\mathrm{Hg}^{0}$ from the atmosphere. The elevated concentrations of $\mathrm{Hg}^{\mathbf{0}}$ emission from mine soil samples probably explains the elevated levels of total $\mathrm{Hg}$ measured in mine vegetation samples.

\section{A Comparison of the Geochemistry of Water Draining from Adits and Tailings Piles in the Coeur d'Alene Mining District: Information for the Geoenvironmental Component of Mineral Deposit Models}

\author{
BALISTRIERI, Laurie S. ', BOOKSTROM, Arthur A. ${ }^{2}$, BOX, \\ Stephen E. ${ }^{2}$, and IKRAMUDDIN, Mohammed ${ }^{3}$ \\ 'U.S. Geological Survey, University of Washington, Box 357940, \\ Seattle, WA 98195, USA \\ ${ }^{2}$ U.S. Geological Survey, West 904 Riverside Avenue, Room 202, \\ Spokane, WA 99201, USA \\ ${ }^{3}$ Geology Department, Eastern Washington University, Mail stop \\ 70, WA 99004, USA
}

The Coeur d'Alene mining district in northern Idaho ranks as one of the world's largest producers of $\mathrm{Ag}$ and one of the United States' major producers of $\mathrm{Pb}$ and $\mathrm{Zn}$. Despite this status, no integrated mineral deposit models exist for this district. We are developing integrated mineral deposit models for Coeur d'Alene deposits that include descriptive, genetic, grade-tonnage, and geoenvironmental information. Data that define the geochemical signatures of Ag-rich, $\mathrm{Zn}$ rich, $\mathrm{Pb}$-rich, and polymetallic deposit types on the environment are used to develop the geoenvironmental component of the models. Part of this effort involves sampling and 
analyzing waters draining from adits and seeping from tailings piles for different deposit types in the district. Preliminary results for two $\mathrm{Zn}$-rich deposits (Success and Interstate-Callahan mines) indicate that drainage from adits is near neutral ( $\mathrm{pH} 6.9$ to 7.4) while drainage from tailings piles is acidic ( $\mathrm{pH} 4.8$ to 6.1). Drainage from tailings seeps contains higher dissolved concentrations of certain elements than from adits at these sites. However, the identity of the elements and the magnitude of enrichment varies between sites. Dissolved $\mathrm{Pb}, \mathrm{Al}$, and $\mathrm{Cu}$ are enriched in tailing seeps relative to adit water at both sites, although the magnitude of enrichment of these elements in different seep water varies considerably $(77-9,000 x$ for $\mathrm{Pb}, 9-4,300 x$ for $\mathrm{Al}$, and 5 $400 \mathrm{x}$ for $\mathrm{Cu})$. Drainage from the Interstate-Callahan tailings are significantly enriched in $\mathrm{Cd}(4,800 \mathrm{x}), \mathrm{Zn}(4,500 \mathrm{x}), \mathrm{Co}$ $(1,800 \mathrm{x}), \mathrm{Mn}(1,200 \mathrm{x}), \mathrm{Ni}(500 \mathrm{x})$, and $\mathrm{Fe}(20 \mathrm{x})$ relative to adit water from the mine and relative to enrichments observed at Success. Tailing seeps from both sites influence metal concentrations in nearby creeks and in the Coeur d'Alene River. Therefore, drainage from mining and mineral processing wastes appears to be an important source of metals to the environment in the Coeur d'Alene valley and must be included in developing the geoenvironmental component of mineral deposit models for this district.

\section{Risk Assessment of Ecosystem Buffering to Acid Input in Russia}

\author{
BASHKIN Vladimir N., and PRIPUTINA Irina V. \\ Institute of Soil Science and Photosynthesis, Russian Academy of \\ Sciences, Pushchino, Moscow region 142292 Russia (e-mail: \\ bashkin@issp.serpukhov.su)
}

This research presents a comprehensive estimation of different geochemical and biogeochemical approaches to analyses of sulfur, nitrogen and acidity critical load (CL) values under the computer calculations for terrestrial and freshwater ecosystems of various regions in Russia, including uncertainty analyses and risk assessment. The CL values are used to set goals for future deposition rates of acidifying and eutrophying compounds so that the environment is protected. In this research $C L$ values for various ecosystems are determined using EM GIS approach. Some software packages (e.g. Statgraphics and UNCSAM) have been used as tools for the analysis. It has been shown that both input source uncertainties and corresponding values of risk assessment were influenced by degree of spatial resolution used for collection of initial information databases. The data for analysis were collected from the large territories of European and Asian parts of Russia. The most influential sources, such as nitrogen, sulfur and base cation uptake by vegetation, surface and ground-water leaching from terrestrial to freshwater ecosystems are described for the whole territory under study regarding uncertainty analysis and the level of corresponding risk assessment. This may be explained by many factors of which the most important are: the estimation of plant uptake is carried out on the basis of data on the biogeochemical cycling of various elements, for which adequate quantitative characterization for all ecosystems under study is either absent or insufficient; reliable information on the quantitative assessment of the ratio between perennial plant biomass increase and dead matter is absent for the required level of spatial and temporal resolution; reliable data on surface and underground runoff in various ecosystems are rare; the influence of hydrothermal factors on the above mentioned processes has not been quantitatively determined at the required level of model resolution. Nevertheless, the determination of the most important parameters of model sensitivity allows us to focus future efforts on collecting all available information on the given parameters and, consequently, to reduce their input uncertainty. The same parameters were responsible for corresponding risk analyses of actual and potential acidification.

\section{Biogeochemical Heavy Metal Regionalization and Human Risk Assessment}

\author{
BASHKIN Vladimir N.', PRIPUTINA Irina V.', EVSTAFJEVA \\ Elena $V_{.}^{2}$, and WILLSON Jeanne \\ 'Institute of Soil Science and Photosynthesis, Russian Academy of \\ Sciences, Pushchino, Moscow region 142292 Russia (e- \\ mail:bashkin@issp.serpukhov.su) \\ ${ }^{2}$ Crimea Medical Institute, Lenin St., 5/7 Symferopol, 333006, \\ Ukraine \\ ${ }^{3}$ Global Environmental Strategies, 5953 South Iola Way, \\ Englewood, CO 80111, USA
}

The main precondition of human risk assessment should be an account of natural biogeochemical regionalization and the determination of all possible biogeochemical food webs, the velocity of migration of pollutants in the food chains and physiological reaction of human organism on the given factors because the influence of different pollutants, especially heavy metals is mediated by biogeochemical organization of the territory. Such interactions are determined for the leading anthropogenic factors, mainly for air and soil pollution, application of agrochemicals (mineral fertilizers and pesticides), and degree of urbanization. So, during 10 years on the basis of resort hospitals the physiological standardized monitoring of people from various regions of Russia, Ukraine and Belarus was carried out. These regions differed on a basis of both anthropogenic loading and natural biogeochemical mapping of heavy metal contents in food webs. This variety of initial conditions, as well as the account of different social aspects and the standardization of monitoring methods, created the unique possibility for complex human risk assessment of influence of different combinations of anthropogenic and natural environmental factors. This human risk assessment was based on complex physiological monitoring including the following: a) total assessment of activity of main organism systems using typical clinical testing; b) physiological testing to assess the regulatory systems of organisms, the degree of their stress and determination of the functional resources; and c) natural 
biogeochemical regionalization. The results obtained proved to be sufficiently informative of such methods as determination of lipid fractions, red and white blood cells, some immune indices of organism as well as EEG testing. The methods of correlative adaptometry and determination of adaptation reaction type also offer perspectives for the risk characterization process. It was shown that among different physiological parameters there are those that are quite sensitive to environmental factors and serve as indicators of varying influence: indices of cell and humoral immunity, reflecting the state of nonspecific sustainability of organism (blood leukocyte spectrum, lizosime); indices of red blood, as well as the parameters of protein and lipid exchange which characterize the activity of main exchange and detoxification by the liver. The degree of pollutant influence on the given physiological indices was mediated by biogeochemical region, being higher in forest-steppe and steppe chernozemic biogeochemical region than in taigaforest nonchernozemic zones.

\section{Geochemistry of Coals Causing Arsenism in Southwest China}

\author{
BELKIN, Harvey E.' ${ }^{\prime}$ ZHENG, Baoshan ${ }^{2}$, and FINKELMAN, \\ Robert B.' \\ 'U.S. Geological Survey, MS 956 Reston, VA 20192, USA \\ ${ }^{2}$ Institute of Geochemistry, Guiyang, China
}

Jomestic combustion of coal for residence heating and food preparation is pervasive in the mountainous regions of Guizhou Province, SW China. The use of high-arsenic $\left(>1000 \mathrm{mg} \mathrm{kg}^{-1}\right.$ ) coals has caused in excess of 3000 cases of arsenic poisoning restricted to several villages. The mineralogy and geochemistry of several high-arsenic coals are being studied by scanning and transmission electron microscopy, electron microprobe and various analytical chemical procedures to determine the concentrations, distributions, and forms of the arsenic. This information should help determine the source of the arsenic and better understand its behavior during the combustion process. Preliminary results from one sample indicate that As contents may exceed $10,000 \mathrm{mg} \mathrm{kg}^{-1}$ in the bulk coal! There are numerous Asbearing phases including arsenopyrite, As-bearing pyrite, As-sulfide (realgar?), Fe-As oxide, As-bearing K, Fe-sulfate (jarosite?), among others. Some of the organic matter appears to be suffused with extremely fine $(\ll<1 \mu \mathrm{m})$ particles of As sulfide. The primary path of human introduction appears to be through ingestion of various vegetables dried in dwellings which do not have chimneys. The vegetables accumulate dust particles from the smoke. In this way, the drying process increases the arsenic content of chili peppers from background levels to as much as $500 \mathrm{mg} \mathrm{kg}^{-1}$.

\section{Manifold Heavy Metal and As Contamination by a German Zn-Pb Deposit With a Two-Thousand Year Mining History}

\author{
BERNER, Zsolt and PUCHELT, Harald \\ Institute for Petrography and Geochemistry, Karlsruhe University, \\ 76128 Karlsruhe, Germany (zsolt.berner@rz.uni-karlsruhe.de)
}

Different mining wastes, from a sulfidic $\mathrm{Zn}-\mathrm{Pb}-\mathrm{Ag}$ deposit in Wiesloch (Germany), with relatively high contents of some minor elements (primarily As, Sb, and $\mathrm{Tl}$, but to a lesser degree also $\mathrm{Se}$ and $\mathrm{Ni}$ ) have largely influenced the environment, contaminating water and agricultural land. Contamination was primarily generated by different kinds of mining wastes (from medieval slag to ore/rock dumps and flotation tailings) deposited on top of a few meter thick loess blanket. Soil contamination, consisting of elevated concentrations (in respect to background values) in $\mathrm{Zn}\left(5300 \mathrm{mg} \mathrm{kg}^{-1}\right)$, Cd (20 $\left.\mathrm{mg} \mathrm{kg}^{-1}\right), \mathrm{Pb}\left(1140 \mathrm{mg} \mathrm{kg}^{-1}\right)$, Tl (100 $\left.\mathrm{mg} \mathrm{kg}^{-1}\right)$, As (1160 mg $\left.\mathrm{kg}^{-1}\right), \mathrm{Sb}\left(20 \mathrm{mg} \mathrm{kg}^{-1}\right), \mathrm{Se}\left(5 \mathrm{mg} \mathrm{kg}^{-1}\right), \mathrm{Ni}\left(42 \mathrm{mg} \mathrm{kg}^{-1}\right)$, led to large infertile spots in the otherwise arable land. Extraction experiments with ammonium nitrate proved that most of these elements could be leached and released in available forms to plants. Mine drainage from old shafts and adits still delivers large amounts of contaminated water (e.g. with up to $100 \mathrm{mg} \mathrm{L}^{-1} \mathrm{As}$, arsenate) endangering creeks and ground water. Experiments were carried out to investigate methods to improve the quality of these waters so that they would be at least suitable for farmland irrigation. The most effective method was to precipitate or adsorb arsenic and heavy metals onto manganese- or iron-oxides. In this way, the concentration of toxic elements was successfully lowered to levels below the guideline values imposed by the German environmental protection authorities. By means of lead and sulfur isotope studies carried out on different constituents of the ore deposit, an attempt was made to confine the origin of the sulfides and sulfates, and to trace them at various stages of transport and deposition.

\section{Chemical and Mineralogical Changes Associated With Leachate Production at Kriel Power Station Ash Dam, Mpumalanga, South Africa}

\section{BEZUIDENHOUT, Nico, WILLIS, James P., and FEY, Martin V. Department of Geological Sciences, University of Cape Town, Rondebosch, 7700, South Africa}

To understand geochemical processes in coal ash dams, a 27 $\mathrm{m}$ core was drilled through the Kriel ash dam, yielding valuable information on secondary weathering. Ash water, leachate and precipitates in drains were sampled. Ash water, used for slurry transport of ash from the plant, was alkaline $\left(\mathrm{pH}>12\right.$ ), dominated by $\mathrm{Ca}^{2+}, \mathrm{SO}_{4}^{-2}$ and $\mathrm{OH} / \mathrm{CO}_{3}^{-2}$ ions and supersaturated with respect to wollastonite $\left(\mathrm{CaSiO}_{3}\right)$, calcite $\left(\mathrm{CaCO}_{3}\right)$, fluorite $\left(\mathrm{CaF}_{2}\right)$ and portlandite $\left(\mathrm{Ca}(\mathrm{OH})_{2}\right)$. The 
leachate from the ash dam was less alkaline ( $\mathrm{pH} 7.2$-11.9) and less saline than the ash water. Extensive precipitation of calcite was found in the solution trench surrounding the ash dam, in leachate drain pipes and in the ash water-return dam. Decreased $\mathrm{SO}_{4}^{-2}$ concentrations in the leachate relative to ash water were less easy to explain; MINTEQA2 calculations showed undersaturation with respect to gypsum, and there was no evidence of gypsum precipitation from drainage solutions. Sulfate attenuation may have occurred by reduction to sulfide, since emission of $\mathrm{H}_{2} \mathrm{~S}$ was detected at some drain openings. Another possibility is precipitation of other sulfate minerals; e.g., the literature documents ettringite $\left(\mathrm{Ca}_{6} \mathrm{Al}_{2}\left(\mathrm{SO}_{4}\right)_{3}(\mathrm{OH})_{2} 26 \mathrm{H}_{2} \mathrm{O}\right)$ formation in weathering ash. Calcite is dominant in secondary precipitates. Redox mobilization of $\mathrm{Fe}$ at the base of the dam produces ferrihydrite at drain openings. The results point to a fortuitous, self-cleansing mechanism producing leachate cleaner than the ash water.

\section{Evaluation of Baseline Soil Geochemistry in Support of Environmental Health Studies in the Rocky Mountain Region}

\author{
BIENIULIS, C. and GUO, X. \\ Foster Wheeler Environmental Corporation, 143 Union \\ Boulevard, Lakewood, CO 80228, USA
}

The determination of baseline geochemistry is important because even the natural levels of some metals in soil may result in human health risk calculations that exceed guidelines for "No further action" at hazardous waste sites. Therefore, objective methods are necessary to determine representative baseline values or to identify contaminant releases, select chemicals of concern, and help establish cleanup goals if remediation is required.

Geochemical data collected from areas considered as background relative to areas impacted by waste disposal activities can be evaluated using a two-tiered methodology. The first method involves the use of a statistical nonparametric analysis of variance (ANOVA) to compare site sample data to the background dataset that helps to identify the constituents which are site contaminants and those constituents which occur naturally. The second method involves the determination of baseline values as either maximum concentrations or upper tolerance limits at $95 \%$ confidence for each inorganic constituent in the background dataset. Ideally, the ANOVA is used to identify metals significantly different and greater than background at individual sites, while baseline values are used as a tool for identifying constituent concentrations in individual site samples that are near or above background.

The methodology presented above has been applied to environmental health studies at sites in New Mexico, Utah, and Wyoming. By applying the nonparametric ANOVA, site contaminants have been easily identified and subsequently supported by comparisons to baseline values. Consequently, the prescribed methodology identified contaminants in these studies that corresponded to components of waste disposed at these sites.

\section{Towards a Contaminant Model for Port Jackson, Sydney's Main Estuary}

\author{
BIRCH, Gavin F. ', TAYLOR, Stuart E. ' , GOBAS, Frank A. ${ }^{2}$ \\ 'Environmental Geology Group, Geology and Geophysics \\ Department, University of Sydney, NSW, 2006, Australia \\ ${ }^{2}$ School of Resource and Environmental Management, Simon \\ Fraser University, Burnaby, B.C., V5A 1S6, Canada
}

A comprehensive study of Sydney's four estuaries (Port Hacking, Botany Bay/Georges River, Port Jackson and Hawkesbury River) has resulted in a large inventory of contaminant (heavy metal, organochlorine/pesticide and nutrient) and sedimentological data. Comparability of the data has been maintained by strictly adhering to a consistent sample acquisition, pretreatment and analytical protocol. Analyses are on a size-normalized basis to avoid confounding texturally-driven distributions and to provide information on source and dispersion processes. Coarse-fraction analysis for heavy metals has enabled sediment quality and biological effects criteria to be assessed for the total sediment.

A number of approaches have been employed to assess the environmental status of these estuaries. Background heavy metal concentrations determined from deep cores have enabled anthropogenic enrichment to be established for each region. The potential effects of heavy metals on biota is estimated using effects-based thresholds established elsewhere.

Sydney, with its present population of about four million, has for almost two centuries used these estuaries as a convenient receptacle for domestic and industrial waste. Port Jackson, with an almost completely urbanized/industrialized catchment, is the most highly impacted of Sydney's estuaries. Mass balance modeling has been undertaken on part of this estuary to provide information on source, determine dominant processes of dispersion and to establish whether contaminants are escaping the estuary.

\section{Geochemical Mapping in the New Federal States of Germany}

\author{
BIRKE, Manfred; RAUCH, Uwe \\ Federal Institute for Geosciences and Natural Resources, Branch \\ Office Berlin, Wilhelmstraße 25-30, D-13593 Berlin, Germany
}

A regional geochemical survey of the five eastern states of the Federal Republic of Germany focusing on major elements, heavy metals and other potential pollutants provides us with information about: natural geochemical background concentrations; the variation of essential parameters such as $\mathrm{pH}$ and electrical conductivity; the distribution of plant nutrients and toxic substances; and the landscape geochemistry, i.e. the natural geochemical pattern and its modification 
by anthropogenic factors. On the basis of these data the anthropogenic contamination resulting from application of agrochemicals and organic fertilizers and from mineral will be analyzed, as well as the leaching of pollutants from soil by the increasing acidification of rain and surface waters. A stream sediment and surface water geochemical survey is the most suitable method of extending the geochemical survey of the older states of the Federal Republic of Germany from 1985 into the new Federal States.

To produce international and global geochemical maps according to the regulations and scale of IGCP 360 , one sample per $400 \mathrm{~km}^{2}$ was collected and analyzed for 54 trace and secondary elements in stream sediments and for 40 parameters in surface waters. Multielement anomalies were determined by using multivariate statistical methods (principal component analysis, cluster Q-analysis). Evaluation of the data, presented on single- and multielement maps, provides a scientific basis for further large-scale environmental surveys by the individual states and small-scale thematic maps when required by ministries and federal administrative authorities.

\section{Environmental Geochemistry in the Surroundings of the Central Waste Deposit of Berlin}

\author{
BIRKE, Manfred; RAUCH, Uwe \\ Federal Institute for Geosciences and Natural Resources, Branch \\ Jffice Berlin, Wilhelmstraße 25-30, D-13593 Berlin, Germany
}

In the region of the central waste deposit of Berlin near the village of Schöneiche the complex geochemical inventory of soils and stream sediments has been determined to differentiate between natural and anthropogenic input in the subsurface of the deposit. On an area of $42 \mathrm{~km}^{2}, 200$ samples of topsoils, stream sediments and surface water were collected and analyzed (main and trace elements, organic parameters like AOX, EOX, cyanide, MHC, phenole, BTEX, LCHC, PCB, PAH, PCDD/F). By means of geochemical load degree maps several polluted areas could be proved in addition to the main deposit.

As a result of the Cluster- $Q$-analysis of the data, Cs, Mo, I, U, Th, Cd, La, and Co are enriched in comparison to the natural background, caused by the waste deposition. In total 23 classes of anomalies describe the anthropogenic pollution in the area of the central waste deposit with concentrations of heavy metals as much as one hundred times higher in relation to the regional geochemical multielement background.

The factor analysis of the inorganic and organic parameters reveals 12 factors which can be related to three groups:

- different types of waste, resulting from a variety of industrial processes and agricultural pollution (fertilization, animal effluent, sewage sludge);

- the geochemistry of the quaternary sediments and;

- environmental influences (biogeochemical barriers).
Sequential extractions of heavy metals from variably polluted samples are yielding information about chemical bonds and retention of pollutants by natural materials below the waste dump.

\section{Buffering of Acid Rock Drainage by Silicate Minerals}

\author{
BLISS, Linda N., SELLSTONE, Christopher M., NICHOLSON, \\ Andrew D., and KEMPTON, J. Houston \\ PTI Environmental Services, 4940 Pearl East Circle, Suite 300, \\ Boulder, CO 8030I, USA
}

Most predictions of acid-rock drainage (ARD) using kinetictest data assume that the only source of acid buffering in the rock matrix is carbonate minerals (e.g., calcite and dolomite). This assumption is implicit in the static acid/base accounting (ABA) method, in which neutralization is determined by the carbonate-carbon content alone. However, silicate buffering may be significant in some systems, and if not considered, acid release predictions may be overestimated. For example, kinetic tests of sulfide-bearing ore and waste from a gold mine generated stoichiometrically less acidity than one would predict by the amount of sulfate released. These rocks contained insufficient carbonate minerals to account for this discrepancy. The difference between predicted and observed acidity, which is attributed to silicate buffering, was as high as $264 \mathrm{meq} \mathrm{kg}^{-1}$. While silicate buffering was an important mechanism in rocks containing feldspars, such as lithic arenite, it was unimportant in rocks that were depleted of their buffering capacity by silicification during hydrothermal alteration. At another mine, ARD was neutralized by waste rock containing much less carbonate than was necessary to achieve this neutralization, assuming carbonate was the only source of buffering capacity. The corresponding increases in aqueous silica concentrations suggests that silicate buffering contributed to the neutralization of the ARD at this site.

\section{Assessment of Suitability of Some Disturbed Land for Herb Cultivation}

\author{
BONDAR, Galina S., KARPOVA, Tamara P., KHARITONOV, \\ Nikolaj $N$. \\ Dniepropetrovsk State Agrarian University, 25 Voroshilov Str., \\ Dniepropetrovsk, 320600 Ukraine
}

Research has been carried out in the field of herb cultivation on disturbed lands. Variable land conditions were tested: with an added layer of black soil and without one (loessial loam soil), with use of fertilizers and without. The control tests were conducted on undisturbed lands. The investigation has shown that the yield on the recultivated lands with a layer of black soil without fertilizers was the same as the control yield of 5 crops among 9 tested. Ononis arvensis $L$. yield was even 1 ton ha ${ }^{-1}$ higher. The yield of the herbs Helichrysum arenarium L., Valeriana officinalis L., Calen- 
dula officinalis $L$. was $0.2-0.3$ ton ha ${ }^{-1}$ less. The yield of all the herbs grown on the plots fertilized with $\mathrm{N}_{80} \mathrm{P}_{80} \mathrm{~K}_{80}$ on the black soil was 0.2-0.3 ton ha ${ }^{-1}$ higher. The yield of all the herbs except Ononis arvensis $L$. was $0.2-0.8$ ton ha ${ }^{-1}$ less on the loessial loam soil than the control one, but the fertilizers gave 0.7-1.0 ton ha ${ }^{-1}$ yield increase. It was established that $\mathrm{Fe}, \mathrm{Cu}, \mathrm{Zn}$, and $\mathrm{Co}$ concentrations were not essentially different, $\mathrm{Mn}$ concentration was 1.5-2.0 times less, $\mathrm{Mg}$ concentration was 1.5-3.0 times more in the herbs grown on the loessial soil than on the black soil.

Based on these results of soil fertility and crop yields, we recommend growing Hypericum perforatum L., Calendula officinalis $L$., Leonurus cardiaca $L$. and others on an added layer of black soil, while both Valeriana officinalis and Ononis arvensis $L$. can be grown on the loessial loam soil, the former with added fertilizer and the latter without. These recommendations guarantee that the herbs obtained will conform to pharmacological standards.

\section{Mass-Balance Study of the Flin Flon Smelter Emissions: Calculations on Metals in Humus in the Flin Flon-Snow Lake Region, Manitoba and Saskatchewan}

\author{
BONHAM-CARTER, G.F. and MCMARTIN, I. \\ Geological Survey of Canada, 601 Booth St., Ottawa, K1A OE8, \\ Canada
}

Elevated levels of $\mathrm{As}, \mathrm{Cd}, \mathrm{Cu}, \mathrm{Hg}, \mathrm{Pb}$ and $\mathrm{Zn}$ occur in the surface organic-rich layer of forest soils in the vicinity of the Flin Flon smelter. The concentrations of these metals decrease logarithmically with increasing distance from the stack until background values are reached, and concentrations are independent of the total organic content within the recognized contaminated zone. A mass-balance study of the smelter emissions was undertaken to assess the proportion of total smelter emissions represented by the well-defined dispersal patterns, and to determine the potential for longrange transport of smelter particles. By making assumptions about 1) background levels of metals in regions remote from the smelter, according to bedrock lithology, 2) the spatial continuity of the humus thickness and metal concentrations, 3) the bulk density of the humus, and 4) the mobility (or lack of it) of the metals within the soil profile and remobilization of metals to the atmosphere, approximate estimates of the mass of the metal in the humus anomaly can be calculated. These are balanced against the annual smelter emission measurements made by Hudson Bay Mining and Smelting Co. who have kept records since the smelter started operation in 1930. A surprisingly large proportion of the historical smelter emissions of some metals, particularly $\mathrm{Zn}$ and $\mathrm{Cu}$, can be accounted for by the corrected humus anomaly, suggesting that these metals have not been transported very long distances from the smelter in the atmosphere. However, other metals can not be accounted for so readily, and this may be the result of uncertainties in the calculations, and from differences in mobility and preservation in the humus.

\section{Solubility of Heavy Metals in Relation to Geological Context: A Theoretical Approach}

BOURG, Alain C. M. and KEDZIOREK, Monika A. M. Laboratory of Aquatic and Environmental Sciences, University of Limoges, 123 Ave. Albert Thomas, 87060 Limoges Cedex, France

The solubility of heavy metals in natural aquatic systems is controlled by competition between processes of solubilization (dissolved complexation) and insolubilization (adsorption and precipitation). These phenomena all depend on the local water chemistry which in turn is controlled by the water-solid interactions occurring in the local geological environment.

Computer calculations describing a series of contrasting geological environments will be presented to illustrate various solubility patterns of toxic heavy metals. The geological contexts presented will deal with situations both natural (ranging from acidic to carbonate environments) and polluted (mine drainage, landfill leachate). These calculations are based on equilibrium conditions and published thermodynamic constants of solution chemistry and precipitation processes. Adsorption is accounted for by the concept of surface complexation.

Of special interest will be the competition between adsorption and precipitation for the control of heavy metal solubility. Model calculations will be compared, whenever possible, to field observations. Model limitations (reaction kinetics and reversibility) also will be discussed.

\section{Migration of Heavy Metals Away from Landfills in Leachate: Observations at the Near- and Far-Field Scale}

BOURG, Alain C.M.', WILLIAMS, Geoffrey $M .^{2}$, BANNON, Michelle P. ${ }^{2}$, PUGINIER, Barbara ${ }^{3}$, RINKE, Mariusz ${ }^{1.4}, B R I L$, Hubert' and MATEJKA, Guy

'Laboratory of Aquatic and Environmental Sciences, University of Limoges, 123 Ave. Albert Thomas, 87060 Limoges Cedex, France

${ }^{2}$ Fluid Processes Group, British Geological Survey, Keyworth, Nottingham, $U K$

${ }^{3}$ BRGM, BP 6009, 45060 Orleans Cedex, France

${ }^{+}$Laboratory of Geology, University of Limoges, 123 Ave. Albert Thomas, 87060 Limoges Cedex, France

Interested parties should contact the author for a copy of this abstract 


\section{A Review of Sulfate Removal Options from Mine Waters}

\author{
BOWELL', R.J., CONNELLY', R.J., ELLIS ${ }^{\prime}, J .$, COWAN ${ }^{2}, J .$, \\ WOOD ${ }^{2}, A$., BARTA ${ }^{3}, J$, and EDWARDS ${ }^{4}, P$. \\ 'Steffen, Robertson \& Kirsten (UK), Summit House, 9 Windsor \\ Place, Cardiff CFI 3BX, Wales \\ ${ }^{2}$ Steffen, Robertson \& Kirsten (CE), SRK House, Illovo, \\ Johannesburg 2116, South Africa \\ ${ }^{3}$ Getchell Gold Company, Golconda PO Box 220, Nevada 89414, \\ USA \\ ${ }^{4}$ Environment Agency, Glen Tawe, Swansea, SAI 4DF, Wales
}

Sulfide oxidation leads to high concentrations of sulfate in contact waters. Levels of sulfate can vary from a few hundred $\mathrm{mg} \mathrm{L}^{-1}$ to several thousand $\mathrm{mg} \mathrm{L}^{-1}$. At very high concentrations (>1000 $\left.\mathrm{m} \mathrm{L}^{-1}\right)$ sulfate has a purgative effect and is considered corrosive on concrete and cement. Current legislation world wide places a limit around $400-500 \mathrm{mg} \mathrm{L}^{-1}$ on ground water and $2000 \mathrm{mg} \mathrm{L}^{-1}$ on industrial effluent; consequently some treatment is often required. In many mine waters selenium as selenite is also present above regulated standards (typically $5-50 \mathrm{~g} \mathrm{~L}^{-1}$ ) and likewise requires treatment before discharge of the contact water. Various treatment options are available for sulfates involving physical, chemical and biological processes. The selection of a treatment option is primarily dictated by sulfate and calcium concentrations. Conventional desalination techniques cannot be economically applied for treating most mine waters due to the problem of $\mathrm{CaSO}_{4}$ scaling. Zonsequently options available include: (1) Reverse osmosis. Where water is low in calcium $\left(<100 \mathrm{mg} \mathrm{L}^{-1}\right)$ and sulfate ( $\left.<700 \mathrm{mg} \mathrm{L}^{-1}\right)$, conventional reverse osmosis can be used, although at higher concentrations of both scaling will occur. A modified special reverse osmosis has been developed to treat mine waters (SPARRO) in South Africa. (2) Ion exchange. Similar to reverse osmosis scaling of $\mathrm{CaSO}_{4}$ is common in conventional circuits. To overcome these problems a modified form of ion exchange has been developed to treat Ca-sulfate waters (GYPCIX). (3) Sulfate coprecipitation. Sulfate barriers may be constructed by using an inorganic source which will produce a low solubility sulfate phase. Both lime and $\mathrm{Ba}$ salts have been proposed. A number of Ba salts can be used but the most commonly proposed are carbonate and sulfide. Because of the cost of $\mathrm{Ba}$ and its environmental toxicity it is advantageous to have a Ba recovery plant to recycle $\mathrm{Ba}$ salts. A typical design would be to reduce the formed Ba sulfate to barium sulfide by roasting with coal, followed by purging with $\mathrm{CO}_{2}$ to produce a recycled batch of $\mathrm{BaCO}_{3}$. Liberated hydrogen sulfide can be used elsewhere in effluent treatment by precipitating insoluble metal sulfides. (4) Biological sulfate reduction. Under anoxic conditions sulfate may be removed from the mine waters as stable sulfide precipitates. Under these conditions sulfide minerals remain stable and ave extremely low solubilities. Flooded underground mine workings and open pits can be anoxic, and as such provide a suitable environment for the implementation of a sulfate reduction system. The presence of sulfides $\left(\mathrm{H}_{2} \mathrm{~S}\right.$ odor $)$ in many mine water discharges indicates that sulfate reduction is already occurring. The reduction of sulfate to hydrogen sulfide is brought about by specialized strictly anaerobic bacteria and is accomplished primarily by two genera: Desulfovibrio (five species) and Desulfotomaculum (three species). These organisms have a respiratory metabolism in which sulfates, sulfites and/or other reducible $S$ compounds serve as the final electron acceptors, with the resulting production of hydrogen sulfide. The organic substrates for these bacteria are generally short chain acids such as lactic and pyruvic acid. In nature these substrates are provided through fermentative activities of other anaerobic bacteria on more complex organic substrates.

Due to the natural occurrence of the sulfate reducing bacteria, sulfate reduction can be utilized in situ for the treatment of acid rock drainage provided the correct conditions can be maintained to sustain bacterial activity. Anaerobic conditions may be enhanced by sealing shafts, adits and air vents. For conditions to be sufficiently anaerobic however, it is likely that a significant depth of water will be required. A wide variety of organic substrates have been investigated for this purpose including molasses, sewage sludge, straw, newspaper, sawdust and manure. Other possibilities are wastes, such as short chain organic acids, from chemical industries.

\section{A Study of the Analytical Variation of Sampling and Analysis of Stream Sediments from Mining and Milling Contaminated Areas}

BRANDVOLD, L. and MCLEMORE, $V$.

New Mexico Bureau of Mines and Mineral Resources, Socorro, New Mexico 8780I, USA

During an environmental study of stream sediments, large variations in metal values were noticed in contaminated sediments taken from the same site at different times. The question arose as to whether these differences were due to variations in contaminant input or merely represented the heterogeneity of the contaminated sediments at the site. Large numbers of replicate samples and measurements could be utilized to help answer the questions, but this is time consuming and costly. Random error can be estimated by the use of a duplicate analyses scheme and much use has been made of duplicate analyses in geochemical surveys and prospecting. In the work reported here, use was made of duplicate analyses to study $\mathrm{Cu}, \mathrm{Pb}$, and $\mathrm{Zn}$ variation in environmental stream-sediment samples. Samples were collected from three areas: (1) adjacent to the La Bajada mine along the Santa Fe River, (2) adjacent to the Pecos mine along the Pecos River, and (3) downstream from the Alamitos mill located on a tributary of the Pecos River. Both rivers are located in northern New Mexico. The mines and the mill have been inactive for many years.

ANOVA statistics were used to evaluate differences in $\mathrm{Cu}$, $\mathrm{Pb}$, and $\mathrm{Zn}$ values between contaminated sites that were 
immediately adjacent. The large variations in metal values noted on earlier trips at the sites on the Pecos River were not noted in this study. Analytical error was the greatest contributor to total variance. Differences in the adjacent site means were most apparent in the smallest size fraction $(<63$ $\mu \mathrm{m})$. But even these differences were shown to be mostly due to random error. The smallest size fraction contained the highest metal values at all three sites. Stream sediments at the La Bajada mine site did not appear to be contaminated.

\section{Metals in an Estuarine System: Sources and Sinks}

\author{
BROWN', Kevin L, WEBSTER ${ }^{2}$, Jenny G., and WEBSTER ${ }^{2}$, Kerry \\ $S$. \\ 'Institute Geological \& Nuclear Sciences, University of Auckland, \\ 26 Symonds St., 92019, Auckland, New Zealand \\ ${ }^{2}$ Institute Environmental Science \& Research, New Zealand
}

The Hatea River estuary system lies adjacent to the town of Whangarei, New Zealand. The watershed includes pastoral, forested, suburban and industrial land, as well as two distinct geological terranes, and the estuary incorporates a large commercial marina. Shallow cores taken from the upper estuary indicated that $\mathrm{Cu}, \mathrm{Pb}$, and $\mathrm{Zn}$ concentrations were up to $600 \%$ higher in the near-surface muds than in underlying sediments. The aim of this study was to identify potential sources and transport/deposition processes, for $\mathrm{Cu}, \mathrm{Pb}$ and $\mathrm{Zn}$ in this catchment.

Metal analyses of bed sediments confirmed that, as expected, streams and storm waters draining suburban and industrial subcatchments had relatively high levels of $\mathrm{Pb}$ and $\mathrm{Zn}$. In the water column, $\mathrm{Pb}$ and $\mathrm{Zn}$ were partially or completely bound to the coarser $(>0.45 \mu \mathrm{m})$ suspended sediments. $\mathrm{Cu}$ on the other hand, was not bound to coarse suspended sediments in the tributaries, and concentrations were generally lower in the bed sediments of suburban streams than in the estuarine sediments. Experimental leaching studies under estuarine conditions showed that $\mathrm{Cu}$ was more readily leached from tributary bed sediments than $\mathrm{Pb}$ and $\mathrm{Zn}$. Consequently, $\mathrm{Cu}$ is unlikely to accumulate in estuarine sediments through a precipitation or adsorption mechanism, but may have a source within the estuary (e.g., antifouling agents).

Relative metal mobilities appeared to be $\mathrm{Cu} \sim \mathrm{Zn}>\mathrm{Pb}$ in the freshwater catchment, and $\mathrm{Cu}>\mathrm{Zn}>\mathrm{Pb}$ in the estuary. The latter was clearly evident in the local dispersion of metals around a storm water outlet where sediments close to the outlet had anomalously high concentrations of $\mathrm{Pb}$ and $\mathrm{Zn}$ (and $\mathrm{As}$ ) but not of $\mathrm{Cu}$.

\section{Recent (1930's) Natural Acidification and Fish Kill in a Lake That Was an Important Food Source to the Population of Akulivik, Northern Québec.}

\author{
CAMERON, Eion M. ${ }^{1.2}$, PRÉVOST, Clément ${ }^{\prime}$, McCURDY, \\ Martin', HALL, Gwendy E.M.' and DOIDGE, Bill \\ ${ }^{\prime}$ Geological Survey of Canada, 601 Booth St., Ottawa, ON, \\ Canada K1A OE8 \\ ${ }^{2}$ University of Ottawa \\ ${ }^{3}$ Kuujjuaq Research Centre
}

Lake Isiurqutuuq was an important source of fish to sustain the local Inuit community until the 1930's when the fish disappeared. At the time this loss was attributed to explosives used by prospectors. A project was undertaken at the request of the people of Akulivik to determine the cause of fish loss and possible remediation. Present lake water is acidic ( $\mathrm{pH} 4.3$ ) and most life forms are absent. A unit of sulfide-rich graphitic shale outcrops on the hillside above the lake. At one place this thickens into a wide lens of sulfide, represented at the surface by an extensive gossan. Streams entering the lake from this gossan have a $\mathrm{pH}$ of 3.4 and high metal contents, including $\mathrm{Zn}, \mathrm{Cd}, \mathrm{Cu}, \mathrm{Ni}, \mathrm{Fe}$ and $\mathrm{Al}$. On entering the lake, $\mathrm{Fe}$ is quantitatively precipitated and the resulting oxide serves to fix much of the dissolved base metals. The lake, while inland, is only $10 \mathrm{~m}$ above sea level in a region of major post-glacial uplift. When the ice retreated $\sim 7000$ years ago the lake was $\sim 140 \mathrm{~m}$ below sea level. The sulfide zone emerged from the sea $\sim 2000$ years ago, when oxidation commenced. Initially, marine shells buffered acid entering the lake. Only after the shells were consumed did the lake water become acid. Diatom analysis of a lake sediment core reveals striking changes that document these events. Clay at the base of the core $(25-28 \mathrm{~cm})$ contains a marine-littoral diatom flora. Following uplift and marine regression, a freshwater diatom community became established, largely dominated by $\mathrm{pH}$-neutral and alkaliphilous taxa. Progressing upcore, increasing acidification is revealed by the appearance and gradual increase in abundance of acidophilous diatoms beginning around $9 \mathrm{~cm}$, and culminating with recent lake-bottom sediments $(0-1 \mathrm{~cm})$ dominated by acidobiontic species. Remediation of the lake is technically possible, because of abundance of sand derived from marine shells that could buffer acid entering the lake. 


\section{A Large-Scale Laboratory Experiment to Determine the Mass Transfer of $\mathrm{CO}_{2}$ From a Sandy Soil to Moving Ground Water}

\author{
CARON, François' ${ }^{l}$ and MANNI, Giulio ${ }^{2}$ \\ 'Environmental Research Branch, Atomic Energy of Canada Ltd., \\ Chalk River, Ont. KOJ 1 JO Canada \\ ${ }^{2}$ CANDU Operations, Sheridan Park, 2285 Speakman Dr., \\ Mississauga, Ont. L5K 1B2 Canada
}

Gaseous ${ }^{14} \mathrm{CO}_{2}$ originating from low-level radioactive wastes buried in the unsaturated zone can be released to the environment via two major routes: gas-phase diffusion through soils to the atmosphere, and by dissolution in ground waters, followed by aqueous migration. The fate of this gas is important for the safety of waste management areas and for waste disposal, because the exposure to humans depends upon the aqueous vs. atmospheric path. One key parameter that influences the relative importance of these paths is the transfer to ground waters, expressed as the mass transfer coefficient KL. Due to the nature of the capillary fringe, located just above the water table, the KL cannot be calculated and it has to be obtained experimentally.

A first step of this experiment, reported elsewhere, was done using static sand columns. In the current work, the experiment was scaled up to a large sand bin $(3.5 \times 2 \times 1 \mathrm{~m})$ with a moving aquifer. Using a mass-balance approach, the $\mathrm{KL}$ determined in this experiment was $\sim 10$ to 20 times smaller than for a quiescent liquid. This implies that the apillary fringe offers a significant resistance to mass transfer, and this should be accounted for in the calculations of the fate of ${ }^{14} \mathrm{CO}_{2}$ near waste management areas.

The objective of this presentation is to give a detailed description of the sand box experiment and the approach to obtain KL. A field application at Chalk River laboratories, near a waste management area, will also be presented.

\section{Textural Analysis and its Importance as Indicator of Energy Levels in Environmental Geochemistry}

\section{CARRANZA-EDWARDS, A. and ROSALES-HOZ, L. ICML, UNAM, Circuito Exterior, Cd. Universitaria, México D.F. 04510}

Environmental geochemical case studies seldom show detailed geological information. This fact is mainly due to the monodisciplinary tendency in environmental research in establishing the problem as well as the possible solution. This talk will present the natural and anthropogenic inputs of heavy metals in different geologic environments (river, beach and continental shelf) and describe how the energy of the depositional environment is related to the grain size of re sediment. It is commonly observed that the higher the average grain size the lower the content of heavy metals, because the energy in the depositional environments may lead to a direct relationship between contaminants and contaminant receptors. One may conclude that the interdisciplinary interaction helps in understanding the environment, and also contributes to discriminate between natural and anthropogenic inputs to natural systems.

\section{Discriminating Between Natural and Anthropogenic Anomalies in the Surficial Environment in Yellowstone National Park, Idaho, Montana, And Wyoming}

CHAFFEE, M.A., HOFFMAN, J.D., TIDBALL, R.R., AND VAN GOSEN, B.S

U.S. Geological Survey, Denver Federal Center, MS 973, Denver, CO 80225, USA

An important goal in the field of environmental geochemistry is to inform the public about what constitutes natural abundances of elements in the surficial environment. This information is particularly important in highly visible areas, such as relatively pristine national parks. In cooperation with the National Park Service, the U.S. Geological Survey is conducting a stream sediment-based environmental geochemical study in selected areas in and near Yellowstone National Park. The goals of the study are to (1) establish a 1990's chemical baseline for scientific reference purposes and (2) identify and distinguish anomalies related to natural features, such as hot springs and chemically contrasting lithologies, from those related to human activities, such as mining and recreation.

Geochemical maps show the effects of past mining activity in the Cooke City area, just outside the northeastern boundary of the park, where anomalies for $\mathrm{Au}, \mathrm{As}, \mathrm{Cu}, \mathrm{Fe}$, $\mathrm{Pb}, \mathrm{S}$, and $\mathrm{Sb}$ have been identified in concentrations that are clearly above their natural levels for that area. Anomalies of these elements extend as much as $20 \mathrm{~km}$ inside the park. In one area, a high concentration of lead was determined to be anthropogenic because of a lack of other elements commonly associated with natural lead anomalies. This anomaly is probably related to fishing or hunting activity. Anomalies of As, Cs, S, Sb, and W were identified in areas of hydrothermally related solfataric alteration. Of these five elements, Cs is the only one not enriched in the Cooke City area, and is therefore the best discriminator between concentrations related to mining activity in the park area and those related to hot spring activity. Elements such as $\mathrm{Ca}, \mathrm{K}, \mathrm{Mo}$, and $\mathrm{Na}$ were not found to be useful indicators of mining activity; however, they help to discriminate between major lithologic units and can therefore be used to assist geologic mapping studies in the park. 


\section{Metal Removal Efficiencies of Substrates for Treating Acid Mine Drainage of the Dalsung Mine, Korea.}

CHEONG, Young-Wook, MIN, Jung-Sik, and KWON, Kwang-Soo KIGAM, 30 Kajung-Dong, Yusung-Ku, Taejon, Korea 305-350

The Dalsung Tungsten mine is located in southeast Korea. The mine was one of the biggest tungsten producers in the 1960's, but closed in 1973. The abandoned mine is located in a mountainous area with nearby agricultural and residential areas. The area is drained by a small stream and is notorious for contamination of surface and ground water. The environmental problems in this area are caused by acid mine drainage (AMD) from seeps. AMD has contaminated the stream and ground water to the point that neither can be used for agricultural supply and drinking water. Water quality of AMD shows high concentrations of $\mathrm{Fe}, \mathrm{Mn}, \mathrm{Zn}$, $\mathrm{Cu}$, and $\mathrm{S}$ and very high acidity compared with the natural waters.

In 1996, the pilot wetland reactor system was installed to treat $\mathrm{AMD}$ and to evaluate metal removal. This system consisted of five $600 \mathrm{~L}$ reactor containers with organic substrates and limestones, with an upward flow direction. Operating duration of the system at this mine was 118 days. Water samples were taken periodically to rapidly detect chemical changes. Water parameters such as $\mathrm{pH}$ and Eh were measured directly in the field and elements such as As, $\mathrm{Cd}, \mathrm{Pb}, \mathrm{Zn}, \mathrm{Cu}, \mathrm{Al}, \mathrm{Fe}$, and $\mathrm{Mn}$ were analyzed in the laboratory.

Effluents from the reactors show that substrates such as mushroom composts, rice stalks mixed with cow manure and limestones worked well to remove metals (especially Fe, Al, $\mathrm{Cu}$, and $\mathrm{Zn}$ ) and acidity. Anoxic constructed wetland filled with above substrates could be an effective treatment method for the AMD.

\section{Geochemical and Lead-Isotopic Studies of the Environmental Effect of Mining at Summitville, Colorado}

CHURCH, Stanley E., WILSON, Stephen A., and BRIGGS, Paul H. U.S. Geological Survey, M.S. 973 Denver Federal Center, Denver, CO 80225, USA

Sediments collected in 1976 and 1994 from the Alamosa River and the Wightman Fork downstream from the Summitville mine were analyzed for their extractable and total metals. The extraction procedures used were the EPA 1311 and 3050 extractions, a $0.25 \mathrm{M}$ hydroxylamine hydrochloride extraction, and a $2 \mathrm{M} \mathrm{HCl}-1 \% \mathrm{H}_{2} \mathrm{O}_{2}$ extraction. The total element composition of the samples was determined using multiacid decomposition $\left(\mathrm{HCl}, \mathrm{HNO}_{3}, \mathrm{HClO}_{4}\right.$, and HF). The leach extraction procedure clearly identified the iron-hydroxide as the mineralogical phase carrying the metals. Concentrations of copper, lead, and zinc in the sediments of the Wightman Fork downstream from the
Summitville mine were substantially elevated in both the 1976 and 1994 geochemical baselines. Aluminum concentrations in the 1994 baseline were about thirty percent higher than in the 1976 baseline. We interpret this increase in aluminum to reflect the opening of the Summitville open pit mine.

The isotopic composition of lead from the seeps and draining adits collected in and around the Summitville deposit in 1995 matched the composition of lead determined in galena prior to the opening of the Summitville open pit mine. Lead-isotopic data from the stream-sediment survey were used to define the relative masses of metal derived from various stream drainage basins using lever-rule calculations. A comparison of the lead-isotopic data in the stream sediments being deposited in 1976 and 1994 indicates that the amount of metal coming from the Summitville mine increased about forty percent in 1994 over that being deposited in 1976.

\section{Isotopic and Chemical Compositions of Rain and Snow Precipitation at Bologna, Italy}

\author{
CORTECCI, Gianni', DINELLI, Enrico ${ }^{\prime}, \&$ MUSSI, Mario ${ }^{2}$ \\ 'Dipartimento di Scienze della Terra e Geologico-Ambientali, \\ Università di Bologna, Piazza Porta S. Donato I, I-40126 \\ Bologna, Italy \\ ${ }^{2}$ Istituto Internazionale per le Ricerche Geotermiche, CNR, Piazza \\ Solferino 2, I-56126 Pisa, Italy
}

Bologna is a densely populated and very busy city surrounded by a wide industrial belt. Therefore, air pollution represents a major environmental problem. In order to trace this phenomenon, a systematic chemical and isotopic study was undertaken since February 1996 on rains and snows collected at the center of the town.

Individual and monthly precipitation has been and continues to be analyzed for isotopes $\left({ }^{2} \mathrm{H},{ }^{3} \mathrm{H},{ }^{18} \mathrm{O}\right.$, and $\left.{ }^{34} \mathrm{~S}\right)$ and individual elements $\left(\mathrm{Ca}^{2+}, \mathrm{Mg}^{2+}, \mathrm{Na}^{+}, \mathrm{K}^{+}, \mathrm{SO}_{4}{ }^{2-}, \mathrm{NO}_{3}-\right.$ and $\mathrm{Cl}^{-}$). Interestingly, the ${ }^{34} \mathrm{~S}$ values of aqueous sulfate display a narrow range from +0.4 to $+3.8 \%$, in spite of remarkable differences in the chemistry and isotopy of rains and snows as well as in the meteorological conditions like wind direction during the precipitation event. The ${ }^{18} \mathrm{O}$ and ${ }^{2} \mathrm{H}$ of water show large variations from -17 to $0 \%$ and -126 to $+6 \%$ respectively, depending on a number of factors including timing and provenance of disturbances.

As far as the chemicals are concerned, $\mathrm{SO}_{4}{ }^{2-}$ to $\mathrm{Cl}^{-}$ratios are normally higher than unity, with concentrations from 1 to $23 \mathrm{mg} \mathrm{L}^{-1}$ for $\mathrm{SO}_{4}{ }^{2-}$ and from 0 to $6 \mathrm{mg} \mathrm{L}^{-1}$ for $\mathrm{Cl}^{-}$. Nitrate ranges between 0 and $17 \mathrm{mg} \mathrm{L}^{-1}$. Calcium is the prevailing cation, followed by sodium, magnesium and potassium. Analyses of heavy metals are in progress. 


\section{The Application of Geochemical Data to Environmental Concerns in the Minas Gerais State, Brazil}

\author{
CUNHA', F.G. MACHADO',G.J. and MELLO', C.S.B. \\ ${ }^{\prime}$ Geological Survey of Brazil - CPRM \\ ${ }^{2}$ Geochemistry Consulting Av. Pasteur 404, Praia Vermelha, Rio \\ de Janeiro, Brazil 222900.040
}

The Geological Survey of Brazil (CPRM) has an extensive geochemical data base covering all of the Brazilian territory. The database, in conjunction with the Geochemistry and Environmental Project, assists in land-use planning such as uses of soil and agricultural productivity related to the control of endemic diseases, and environmental management. In 1977 the area for the Sapucai Project was selected as the Poços de Caldas and Varginha cities, Minas Gerais, (MG) State. The region encompasses an area of about $44,880 \mathrm{~km}^{2}$ and has geological and geochemical coverage made by CPRM. This study was based on the results from the chemical analyses of $\mathrm{Pb}, \mathrm{Zn}, \mathrm{Ni}, \mathrm{Cr}, \mathrm{Cu}, \mathrm{Co}$ and $\mathrm{Mo}$ based on an environmental study of 590 stream sediment samples. Using GEOSOFT software, geochemical maps for the selected elements were created. After data analysis, two areas for detailed examination were selected: Poços de Caldas showed high concentrations of Mo and low contents of $\mathrm{Cu}$ (possible problems for livestock and human health, such as molybdenosis and hypocuprosis); and Sao Goncalo de Sapucai. These areas represent old mining activities and new agricultural activity. The correlation between these geochemical data sets and those available from public heath sources are being examined for the Poços de Caldas area. The study examines the utility of these data sources in assisting local governments to solve environmental geochemical problems.

\section{Application of Mine Fire Diagnostics}

\author{
DALVERNY, L.E.', CHAIKEN, R.F. ${ }^{2}$, and KIM, A.G.' \\ 'Federal Energy Technology Center, P.O. Box 10940, Pittsburgh, \\ PA 15236, USA \\ ${ }^{2}$ Pittsburgh Research Center, NIOSH, P.O. Box 18070, Pittsburgh, \\ $P A$ 15236, USA
}

Mine Fire Diagnostics is based on the assumptions: (1) measurable changes in the emission of low molecular weight hydrocarbons from coal are temperature dependent, and (2) analysis of controlled underground air flow between borehole sampling points can determine the source of the hydrocarbons. Gas composition, temperature, and pressure are determined before and during operation of a suction fan attached to one of a network of cased boreholes. Fan suction influences gas movement at the base of neighboring boreholes, and differences in measured pressure indicate the degree of communication between the suction and other boreholes. A fire signature is based on a ratio of $\mathrm{C}_{2}-\mathrm{C}_{5}$ hydrocarbons to total hydrocarbons. Using a gas chromatograph, the detection level for hydrocarbons is I ppm; a sample can be analyzed in less than 2 minutes. Laboratory studies confirm that changes in hydrocarbon emission are detectable at temperatures below $100^{\circ} \mathrm{C}$. Integrating fire signatures from multiple tests, with different underground gas flow orientations, produces a two-dimensional map of heated and cold zones.

The methodology has been used at four abandoned coal mine sites, three bituminous and one anthracite. Three noncontiguous combustion zones were delineated at the first site. At the second site, it was determined that heating extended several hundred feet into the mine and along more of the buried outcrop than indicated by surface expression. The third evaluation indicated possible heating near some houses; assessment was complicated by apparent low permeability in the mine. In the anthracite mine, changes in methane concentrations indicated the presence of seven noncontiguous heated zones.

\section{Environmental Applications of the Regional Geochemical Mapping of Soils and Stream Sediments in South Africa}

de BRUIN, D., ELSENBROEK, J.H., and LOMBARD, M. Council for Geoscience, Private Bag X 112, Pretoria, 0001, South Africa

A regional geochemical mapping program has been conducted in South Africa since 1973 by the Council for Geoscience. A total area of 280,000 square kilometers have been covered to date at a sampling density of one sample per $\mathrm{km}^{2}$. This represents coverage of $23 \%$ of the surface area of South Africa. Samples from first order streams are preferentially collected, but representative soil samples are taken if these are not present within the designated square kilometer. The $<75 \mu \mathrm{m}$ fraction of samples is collected by dry sieving and analyzed for 24 elements $\left(\mathrm{TiO}_{2}, \mathrm{MnO}, \mathrm{Fe}_{2} \mathrm{O}_{3}-\mathrm{T}, \mathrm{Sc}, \mathrm{V}\right.$, $\mathrm{Cr}, \mathrm{Co}, \mathrm{Ni}, \mathrm{Cu}, \mathrm{Zn}, \mathrm{As}, \mathrm{Rb}, \mathrm{Sr}, \mathrm{Y}, \mathrm{Zr}, \mathrm{Nb}, \mathrm{Mo}, \mathrm{Sn}, \mathrm{Sb}, \mathrm{Ba}$, $\mathrm{W}, \mathrm{Pb}, \mathrm{Th}, \mathrm{U})$ by simultaneous XRF on pressed powder pellets. Samples from selected areas have also been analyzed for additional elements ( $\mathrm{Pt}, \mathrm{Pd}, \mathrm{Au}$ and major elements) using other analytical techniques. The results are processed by using a Geographical Information System (GIS). The XRF results show an excellent correlation between soil chemistry and underlying geological formations. Geological units are clearly demarcated even on 1:50,000 scale maps (700 samples), and on larger scales the chemistry clearly reflects regional geological patterns. Apart from geological correlations the data set can also used for exploration purposes, the establishment of environmental baselines within geological units, and agricultural applications. An advantage of the methodology followed by this program is that all sample materials are stored and archived, which allows for samples to be analyzed by other and future advanced analytical techniques for additional elements as the need arises.

Prominent anthropogenic contamination can be readily detected in two separate mining areas. The area surrounding 
the copper smelter at O'Kiep in the Northern Province is surrounded by a distinct increase in copper values across geological boundaries. At Rustenburg, the center for the processing of PGE ore from the Western Bushveld situated in the Northwest Province, high levels of $\mathrm{Cu}, \mathrm{Ni}, \mathrm{Pt}$, and $\mathrm{Pd}$ are clearly detected in surrounding areas. Significant correlations were also found between geochemical signatures and the reported condition of geophagia and hepatitis in cattle and sheep grazing in areas underlain by a specific dolomite formation.

\section{Geochemical Assessment of Passive Treatment Methods for Acid Mine Waters from a Flooded Uranium Mine}

\author{
DEISSMANN, Guido', KISTINGER, Stephan', PLÜGER, W.L. ${ }^{2}$ \\ 'Brenk Systemplanung Heider-Hof-Weg 23, D-52080 Aachen, \\ Germany \\ ${ }^{2}$ Institute of Mineralogy and Economic Geology, Aachen \\ University of Technology, Walinerstr. 2, D-52056 Aachen, \\ Germany
}

The generation of acid mine waters, commonly termed acid mine drainage, is one of the key environmental aspects of mining if sulfide bearing ores are mined. The discharge of such acid mine waters, strongly enriched in sulfate, heavy metals, and radionuclides, after the flooding of the underground operations of an abandoned uranium mine in East Germany might cause contamination of ground and surface waters and prove to be hazardous to the environment. This paper outlines the assessment of different approaches for an in situ treatment of these mine waters by conventional neutralization methods like addition of caustic soda or lime and by treatment methods using cheap industrial materials such as fly ash from lignite-burning power plants and scrap iron. Focal points are the effectiveness of the various methods and the mechanisms of the reduction of contaminant levels. The results of a laboratory study indicate that, besides neutralization with lime or caustic soda, water treatment with fly ash or fly-ash cement is an effective method for the in situ neutralization of acid mine waters and the reduction of contaminant levels. In contrast, due to kinetic reasons, the underground storage of scrap iron is not an effective method for the removal of uranium from acid mine waters, although neutral $\mathrm{pH}$ and reducing conditions can be obtained, which result in a decrease in the concentration levels of various other toxic heavy metals in the mine water.

\section{Trace-Element Contamination in The Environment of Recife Metropolitan Area, Pernambuco, Brazil}

\author{
DeLIMA, Edmilson S., SILVA, Maria do Carmo T., FLORENCIO, \\ L., ESPIRITO SANTO, Lidiane S. do
}

Av. Acad. Helio Ramos S/N, 50.740-530, RECIFE, PE, Brazil

The purpose of this study is to evaluate qualitatively and quantitatively the contamination of the environment with heavy metals in the Recife Metropolitan Area (RMA), Pernambuco State, Brazil. To achieve this objective, aerosol-loaded filters, collected through a network of 10 monitoring stations in the RMA by the local environmental agency (CPRH) will be analyzed. The first station was installed in 1991 in Downtown Recife. So far, only total suspended particulate (TSP) concentrations have been determined for all stations. In some stations smog, sulfur, and nitrogen oxides have been determined (CPRH, 1996). A total of 788 well-kept aerosol-loaded filters have been collected through high-volume manual samplers. Using TSP concentration data for a four-year period (1991-1994), the air quality in Recife Metropolitan Area has exceeded the primary standard values, according to Brazilian standards in the three stations.

A preliminary site characterization is being made at the Santo Antonio (downtown) Station, which exceeded the TSP primary standard values. This will provide a first insight into the heavy metal concentration versus Total Suspended Particles. Among the 788 aerosol-loaded filters collected, 33 were analyzed for $\mathrm{Zn}\left(0.1-1.0 \mathrm{mg} \mathrm{m}^{-3}, \mathrm{~Pb}(0.009-0.003\right.$ $\left.\mathrm{mg} \mathrm{m}^{-3}\right), \mathrm{Cd}\left(0.001-0.002 \mathrm{mg} \mathrm{m}^{-3}\right), \mathrm{Cu}\left(0.001-0.019 \mathrm{mg} \mathrm{m}^{-3}\right)$, $\mathrm{Fe}\left(0.010-0.020 \mathrm{mg} \mathrm{m}^{-3}\right), \mathrm{Mn}\left(0.003-0.009 \mathrm{mg} \mathrm{m}^{-3}\right), \mathrm{Ni}$ (0.001-0.002 $\mathrm{mg} \mathrm{m}^{-3}$ ). These analyses showed a higher concentration of metals during the dry season (August to February) than those for the wet season (March to July). As a result, the local environmental agency can make recommendations for pollution reduction and propose relevant legislative measures where applicable.

Support for this study: CPRH/FACEPE/UFPE

\section{Environmental Geochemical Mapping in Sardinia (Italy)}

DE VIVO, Benedetto, BONI, Maria, and COSTABILE, Salvatore Dipartimento di Geofisica e Vulcanologia and Dipartimento di Scienze della Terra, Univ. Napoli "Federico II", Via Mezzocannone 8, 80134 Napoli, Italy

Geochemical data obtained during regional mineral exploration programs carried out by the Italian Government in different regions of Italy in the 1970's and 1980's, can be reutilized to compile regional geochemical baseline maps. Geochemical baseline maps, in Italy, have already been compiled by our research group for two Regions, Calabria and Monti Peloritani (Sicily) and, partially, for Sardinia. We 
report here results of the maps covering much larger areas of Sardinia compared with the maps already compiled. Sardinia is a mining region active for 2,000 years. It has been explored at a regional scale, but with only a few letailed follow-up studies in some specific areas. Geologically, Sardinia is made up of a Paleozoic igneous and metamorphic basement, with a Mesozoic-Tertiary volcanosedimentary cover. The most important tectonic imprint is due to Hercynian orogenesis; Caledonian and Alpine events are responsible of minor deformations associated to magmatic activity. Base-metal mineralization, in addition to $\mathrm{Ba}$, $\mathrm{F}, \mathrm{Mo}, \mathrm{Sn}, \mathrm{Sb}$ and recently also $\mathrm{Au}$, occur in all the lithologies of Sardinia, with a preferential concentration in Paleozoic terranes. Economically, the most important ore deposits are located in the southwestern part of the island (Iglesiente-Sulcis), where for centuries $\mathrm{Zn}, \mathrm{Pb}, \mathrm{Ag}, \mathrm{Cu}$, and $\mathrm{Ba}$ have been mined. Today most of these mines are closed; however, it is anticipated that Au mining operations in the Tertiary volcanic series will open soon.

Geochemical maps of Sardinia have been constructed using stream sediment analytical baseline data from regional drainage surveys carried out in the 1970's and 1980's by the Ente Minerario Sardo (EMS) on behalf of the Italian Government. The stream sediments utilized for this study vary from an average minimum of 4,500 to an average maximum of 23,000 samples. The area covered also varies from about $13,000 \mathrm{~km}^{2}$ to $17,000 \mathrm{~km}^{2}$. A total of 56 elements have been analyzed by Atomic Absorption and INAA. Univariate and multivariate statistical analysis has seen carried out on the analytical data to produce maps illustrating the regional variability of each element, as well as maps showing the distribution of factor scores of elemental associations resulting from $\mathrm{R}$-mode factor analysis. The geochemical maps resulting from this study are useful in preparing environmental assessments, guidelines, and regulations in addition to their primary purpose as a tool addressed at mineral exploration.

\section{Plant-Soil Relationships in the Serpentinite Screes of Mt. Prinzera, Northern Apennines, Italy}

\author{
DINELLI, Enrico', LOMBINI, Allessandra ${ }^{2}$, FERRARI, Carlo ${ }^{2}$, \\ and SIMONI, Andrea \\ 'Dipartimento di Scienze della Terra e Geologico-Ambientali, \\ Università di Bologna, Piazza di Porta S. Donato, 1; I-40126 \\ Bologna \\ ${ }^{2}$ Dipartimento di Biologia Evolutiva, Università di Bologna, $V$. \\ Irnerio, 42; I-40126 Bologna \\ ${ }^{3}$ Istituto di Chimica Agraria, Università di Bologna, Viale Berti \\ Pichat, I0, I-40127 Bologna
}

The study of soil chemistry and metal accumulation in some plants growing on the serpentinite screes of Mt. Prinzera (PR) was performed. Sampling surveys were carried out over two years (May 1994 and May 1995) in the same locations. Bulk soil chemical composition was determined by X-Ray Spectrometry, extractable fractions of $\mathrm{Ni}, \mathrm{Cr}, \mathrm{Co}$,
$\mathrm{Cu}, \mathrm{Zn}$, and Fe (measured by both EDTA and DTPA), and of $\mathrm{Ca}, \mathrm{Mg}$ and $\mathrm{K}$ (measured by $\mathrm{NH}_{4} \mathrm{OAc}$ ) were evaluated. All these elements were analyzed on whole plant, aerial parts, leaves and roots.

High concentrations of $\mathrm{Mg}, \mathrm{Fe}$, and heavy metals (3,500 $\mathrm{mg} \mathrm{g}^{-1} \mathrm{Cr}, 2,200 \mathrm{mg} \mathrm{g}^{-1} \mathrm{Ni}, 160 \mathrm{mg} \mathrm{g}^{-1} \mathrm{Co}$ ), low levels of macronutrients $(\mathrm{Ca}$ and $\mathrm{K}$ ); and a $\mathrm{Ca} / \mathrm{Mg}$ ratio always $<1$ characterize this environment. A direct correlation exists between extractable metal and total soil content both for EDTA and DTPA. A negative correlation is displayed by $\mathrm{Mg}_{\mathrm{NH} 4 \mathrm{OAC}}$ and $\mathrm{Cr}_{\mathrm{EDTA}}$. The extractable fractions do not show clear relations to concentration observed in plants, which may suggest that a specific effect must play an important role in metal uptake in plants.

Higher concentrations are observed in the aerial parts of the plants, without significant variations between 1994 and 1995. The Ni hyperaccumulation of Alyssum bertolonii Desv. $\left(2,115-5,860 \mu \mathrm{g} \mathrm{g}^{-1} \mathrm{Ni}\right)$ is confirmed. Our data point out also high $\mathrm{Cr}\left(175-395 \mu \mathrm{g} \mathrm{g}^{-1}\right)$ and $\mathrm{Fe}(4,000-13,500 \mu \mathrm{g}$ $\mathrm{g}^{-1}$ ) concentrations in Dianthus sylvestris Wulfen. Among the taxa considered, according to decreasing BAC (concentration in plant/total soil concentration) values, a general sequence like $\mathrm{Zn}>\mathrm{Cu}>\mathrm{Co}><\mathrm{Ni}>\mathrm{Cr}$ can be generalized. However Alyssum bertolonii Desv. and Silene armeria L. tend to preferentially concentrate $\mathrm{Ni}$ and $\mathrm{Cu}$ respectively (Lombini et al., 1995a; 1995b; Dinelli and Lombini, 1996).

Dinelli E. \& Lombini A. (1996). Applied Geochem., 11, 375-385. Lombini A., Pandolfini T., Ferrari C. \& Dinelli E. (1995a). 2nd inter. Conf. on Serpentine Ecology, Noumea, 65.

Lombini A., Ferrari C., Calzoni G.L. \& Dinelli E. (1995b). Giorn. Bot. It., $129(2), 147$.

\section{Classifying and Mapping the Sensitivity of South African Highveld Soils to Acidification}

\section{DODDS, Heather A., and FEY, Martin V. Department of Geological Sciences, University of Cape Town, Rondebosch, 7700, South Africa}

The buffer capacity of soils affects the extent to which land and water become degraded by the acidifying effects of air pollution and land use practices such as forestry. Over the last three decades, soils of the industrialized South African highveld have been mapped as land types at a scale of $1: 250,000$. These maps were used as a basis for applying the Skokloster and Stockholm Environmental Institute classification systems in assessing critical acidification loads in this strongly polluted region. The inconsistent results obtained were attributed to a possible overemphasis by these classification systems on soil mineralogy, especially in the context of the highly weathered nature of many highveld soils. Also, mineralogical composition cannot accurately be inferred from soil maps prepared with the South African system of soil classification. As an alternative, a simple buffer method for determining acid neutralizing capacity (ANC) was applied to 145 well-characterized soils from the 
region. The method consists of equilibrating a soil sample with an acidic, acetate buffer solution and measuring the resultant suspension $\mathrm{pH}$. The correlation of ANC with routinely determined soil properties (e.g., base saturation and texture) was then used to derive maps from land type data which show, at 1:250,000, the sensitivity of the soil mantle to acidifying impacts in terms of the proportion of soils falling into different sensitivity classes. The maps have helped us focus on areas of priority for impact studies, while the classification itself, when applied to individual soil types, provides a basis for land management employing existing soil maps at any scale. The ANC determination provides an inexpensive, quantitative index of soil buffer capacity which can be employed for routine characterization of soils.

\section{Mercury Occurrence, Transport, and Speciation in the Sacramento River Basin, California}

\section{DOMAGALSKI, Joseph L.}

U.S. Geological Survey, Placer Hall, $6000 \mathrm{~J}$ Street, Sacramento, CA 95819-6129, USA

Mercury poses a water-quality problem for California's Sacramento River - a large river with a mean annual discharge of over $650 \mathrm{~m}^{3} \mathrm{~s}^{-1}$. Total $\mathrm{Hg}$ concentrations in the lower reaches of the Sacramento River exceed State and federal guidelines of $12 \mathrm{ng} \mathrm{L}^{-1}$ for up to $30 \%$ of the year. This river discharges into the San Francisco Bay, and numerous fish species of the bay and river contain $\mathrm{Hg}$ levels high enough to affect human health. One potential source of $\mathrm{Hg}$ is from deposits, which were once mined in the Coast Ranges, west of the Sacramento River, and used to process gold in the Sierra Nevada, east of the river. Mercury from Coast Ranges streams probably is not a significant source to the Sacramento River except during flood years because at other times flow from those streams seldom reaches the Sacramento River. Residual $\mathrm{Hg}$ from mineral processing in the Sierra Nevada is mainly in elemental form or in association with oxide particles or organic matter and is known to be biologically available. The massive sulfide deposits of the West Shasta mining district in the upper part of this basin are another potential source of mercury. Recent bedsediment sampling showed elevated levels of total $\mathrm{Hg}$ (median concentration: $0.28 \mu \mathrm{g} \mathrm{g}^{-1}$ ) in every large river draining the Sierra Nevada gold region. Reservoirs now act as a sink for biologically available $\mathrm{Hg}$, but downstream contaminated sediments still present a problem, especially during periods of high flow when bed sediments are resuspended. Early results from a one-year program of total methyl mercury sampling showed very low concentrations (median concentrations of $0.08 \mathrm{ng} \mathrm{L}^{-1}$ ) in the reach of the Sacramento River above the confluence with the rivers draining the Sierra Nevada and above the major agricultural inputs to the Sacramento River. Higher concentrations (median concentration: $0.14 \mathrm{ng} \mathrm{L}^{-1}$ ) and greater variability in concentration were measured downstream of those sources. Though this increase may be partially attributable to transport of methyl mercury from Sierran rivers, methylation of $\mathrm{Hg}$ in rice fields irrigated with Sacramento River water may also play a significant role in the increase in concentrations.

\section{Effects of Evapoconcentration on Water Quality in Mine Pit Lakes}

\author{
EARY, L. Edmond, and DAVIS, Andy \\ Geomega, 2995 Baseline Rd., Suite 202, Boulder, CO 80303, USA
}

In Nevada, there are over 30 open pits where low-grade precious metal deposits are being worked. Many of these deposits are hosted in carbonate rocks and located in hydrologic sinks. Hence, an environmental concern for closure is not necessarily acid mine drainage, but the potential creation of pit lakes with excessive alkalinity from evapoconcentration. PHREEQC simulations of the evaporation of existing pit lakes indicate that those with $2\left[\mathrm{Ca}^{2+}\right]<$ $\left[\mathrm{HCO}_{3}{ }^{-}\right](e . g .$, Cortez pit) will initially precipitate calcite at $\mathrm{pH}$ 8.1. With continued evaporation, calcite formation depletes solutions of $\mathrm{Ca}^{2+}$, leaving excess carbonate, eventually producing waters with $\mathrm{pH}$ 's $>9.2$ and alkalinities $>6900 \mathrm{mg} \mathrm{L}^{-1}$. Anions, such as As, B, and Se, increase linearly with evapoconcentration because of no solubility controls and decreased adsorption in alkaline conditions. These pits are analogous to natural lakes, such as Walker Lake, $\mathrm{NV}$, that has a $\mathrm{pH}$ of 9.5 and $1.1 \mathrm{mg} \mathrm{L}^{-1}$ of As. In contrast, in pit lakes with $2\left[\mathrm{Ca}^{2+}\right]>\left[\mathrm{HCO}_{3}^{-}\right]$(e.g., Yerington pit), evaporation initially causes calcite formation at $\mathrm{pH} 8.1$; a process, in this case, that removes carbonate but leaves excess $\mathrm{Ca}^{2+}$. Gypsum solubility is eventually reached resulting in a $\mathrm{pH}$ of 7.9 after a 100 -fold evapoconcentration, while As and Se levels remain nearly constant because of partial adsorption in near neutral conditions. These pits are analogous to Carson Sink; a lake that has evaporated for thousands of years but has a $\mathrm{pH}$ of 7.8. The simulations indicate that the classical concepts of chemical divides are applicable to predicting water quality in evapoconcentrating pit lakes and that natural lakes can provide insight on their evolution.

\section{The Development of a Biological Toxicity Based Test for Water Quality}

EDWARDS, Robert', CRONIN, Mark T.P.', MERCHANT, David', SCULLY, Patricia', WALLACE, Peter', and GRABOWSKI, Josef ${ }^{2}$ 'Liverpool John Moores University, Byrom Street, Liverpool, L3 $3 A F, U K$

${ }^{2}$ Institute of Physics, Poznan Technical University, Piotrowo 3, 60-965 Poznan, Poland.

Ascertaining the quality of water is important to maintain and restore its suitability for particular users. Direct measurement of the toxicity of surface waters and effluents, 
based on the response of a biological indicator, overcomes the need to individually measure variables such as $\mathrm{pH}, \mathrm{BOD}$, and organic and metal concentrations. It also offers the advantage of determining the toxicity of effluents which zontain complex mixtures of chemicals which exert synergistic and antagonistic toxic effects and where no toxicity data exists.

A rapid method for toxicity testing has been developed using a common algae (Chlorella vulgaris). The test depends on the ability of a standard concentration of the algae to enzymatically hydrolyze fluorescein diacetate (FDA - a non-fluorogenic compound) to the fluorescent compound fluorescein. The rate of hydrolysis is measured using a Perkin Elmer MPF 4A spectrofluorimeter over a period of 10 minutes.

In this study, a carefully selected group of compounds acting by the non-polar narcosis and polar narcosis mechanism of action were tested over a concentration range. From the results NOE (no observable effect) and $\mathrm{LC}_{50}$ concentrations were determined.

Quantitative Structure Activity Relationships (QSAR), which relate the biological or toxicological activity of a chemical compound to some aspect(s) of its physicochemical structure, were determined. QSARs provide a means both to predict the toxicity of untested compounds and shed light on the mechanism of toxic action. QSARs based upon the 10-minute $\mathrm{LC}_{50}$ are presented and show the expected excellent correlations with the hydrophobicity (octanol-water partition coefficient $(\log P)$ ) of the compounds studied.

The QSARs based on the acute algal toxicity are statistically significant and comparable to those for other algal and aquatic species. This demonstrates the potential of this method to provide a rapid and cost effective toxicity test for organic compounds.

\section{Biogeochemical Mechanisms Influencing Metal Mobility in Natural and Constructed Wetlands}

\author{
EDWARDS, P. ${ }^{\prime}$, BOWELL, R.J. ${ }^{2}$, CONNELLY, R.J. ${ }^{2}$ and WOOD, \\ A. ${ }^{3}$ \\ 'The Environment Agency, Glan Tawe, Swansea, SAI 4DF, Wales \\ ${ }^{2}$ Steffen, Robertson and Kirsten (UK) Ltd, Summit House, Cardiff, \\ CF1 3BX, Wales
}

${ }^{3}$ Steffen, Robertson and Kirsten (CE), SRK House, Illovo, Johannesburg, South Africa

The Pelenna River system has been impacted by ferruginous discharge from abandoned coal mines for more than 25 years. As well as the impact on water quality in their receiving rivers, a major aesthetic impact has also occurred due to ferric oxyhydroxide precipitation in river sediments. 4ssociated with this are low populations of fish and macroinvertebrate communities. Iron concentrations upstream of the discharge were in the range $0.06-4.53 \mathrm{mg} \mathrm{L}^{-1}$, but where mine water discharges enter the water courses, mean $\mathrm{Fe}$ concentration ranges from $25-43 \mathrm{mg} \mathrm{L}^{-1}$. The most signifi- cant discharge in terms of $\mathrm{Fe}$ loading is from the Garth Tonmawr wetland, from which approximately $67 \mathrm{~kg}$ per day of $\mathrm{Fe}$ is discharged into the Blaenpelenna River. Despite large accumulations of $\mathrm{Fe}, \mathrm{Mn}$, and $\mathrm{SO}_{4}{ }^{2-}$ in sediments in this natural wetland, outflow and mine water inflow into the wetland. This suggests that a maximum loading of these elements can be anticipated in a wetland after which little chemical precipitation occurs.

Within a constructed wetland, attenuation of $\mathrm{Fe}$ and $\mathrm{SO}_{4}{ }_{4}^{2-}$ is around $50 \% ; 15-20 \%$ for $\mathrm{Mn}$. However, based on the natural wetland study it is predicted that in time this too will gain a critical loading for precipitates after which outflow chemistry from the wetland will be similar to inflow. From a literature review no constructed wetland has been found which has been effective for $\mathrm{SO}_{4}{ }^{2-}$ removal for more than 3 years and for $\mathrm{Fe}$ removal for more than 10 years. Consequently in the treatment of mine drainage, wetlands cannot be considered as a "walk away" solution and after a period of time (on the order of 5-10 years) they will no longer continue to operate effectively.

\section{Influence of Bicarbonate on Pyrite Oxidation}

EVANGELOU, V.P. and SETA, A.K. Department of Agronomy, N-122 Agricultural Science Building, N., University of Kentucky, Lexington, KY 40546, USA

A mechanism explaining enhancement of abiotic pyrite $\left(\mathrm{FeS}_{2}\right.$ ) oxidation in circumneutral $\mathrm{pH}$ environments is $\mathrm{OH}^{-}$ involvement in an inner-sphere electron transfer process. In this process an $\mathrm{OH}^{-}$and an electron are exchanged simultaneously between pyrite surface- $\mathrm{Fe}(\mathrm{III})(\mathrm{OH})_{n}{ }^{3-n}$ and pyrite surface disulfide. Data in the literature suggest that bicarbonate $\left(\mathrm{HCO}_{3}{ }^{-}\right)$could abiotically promote pyrite oxidation, but this mechanism is not understood and evidence is lacking. This study was carried out to elucidate the potential role of $\mathrm{HCO}_{3}$ - on pyrite oxidation. Evidence obtained from our previous studies, using FT-IR spectroscopy, demonstrated that pyrite exposed to humidified $\mathrm{CO}_{2}$ plus $\mathrm{O}_{2}$ formed pyrite surface- $\mathrm{Fe}(\mathrm{II})-\mathrm{HCO}_{3}$ complexes. Based on the above results, it was postulated that $\mathrm{HCO}_{3}$, having the potential to form pyrite surface $\mathrm{Fe}(\mathrm{II})-\mathrm{HCO}_{3}$ complexes, would promote abiotic pyrite oxidation by accelerating oxidation of $\mathrm{Fe}(\mathrm{II})$. The latter ( $\mathrm{Fe}(\mathrm{II})$ ) would oxidize the disulfide $\left(\mathrm{S}^{2-}\right)$ by accepting its electrons. Using a miscible displacement technique, oxidation of $\mathrm{FeS}_{2}$ with $\mathrm{H}_{2} \mathrm{O}_{2}$ was carried out in the absence or presence of 10 or $100 \mathrm{mmol} \mathrm{L}^{-1} \mathrm{NaHCO}_{3}$. The data showed that $100 \mathrm{mmol} \mathrm{L}^{-1} \mathrm{NaHCO}_{3}$ significantly increased the oxidation rate of $\mathrm{FeS}_{2}$. Furthermore, the data showed that $\mathrm{FeS}_{2}$ oxidation kinetics were dependent on $\mathrm{H}_{2} \mathrm{O}_{2}$ concentration at the $10 \mathrm{mmol} \mathrm{L}^{-1} \mathrm{HCO}_{3}^{-}$, but were less dependent on $\mathrm{H}_{2} \mathrm{O}_{2}$ concentration at $100 \mathrm{mmol} \mathrm{L}^{-1} \mathrm{HCO}_{3}^{-}$. These results are consistent with the findings of our FT-IR spectroscopic studies and published data which showed that $\mathrm{Fe}$ (II) oxidation in solution was enhanced in the presence of solution $\mathrm{HCO}_{3}^{-}$. 


\section{Biodegradation of ${ }^{14} \mathrm{C}$ Labeled Organic Acids and Organo-Metal Complexes in Soil}

EVANS, Andrew, Jr.

Department of Integrated Science and Technology, James

Madison University, Harrisonburg, VA 22807, USA

Low-molecular-weight organic acids are produced in soil by various biological and chemical processes. These compounds can exhibit substantial metal complexing and mineral dissolution capacity, while being subject to microbial degradation. Microbial degradation of noncomplexed and $\mathrm{Al}-, \mathrm{Cu}$-, and $\mathrm{Pb}$-complexed radiolabeled organic acids were studied using soil biometer flasks containing various forest soil horizons. To each soil sample, $5.0 \times 10^{-5}$ mole of organic acid containing $3.7 \times 10^{4} \mathrm{~Bq}$ total activity was applied. The ${ }^{14} \mathrm{C}$-radiolabeled materials studied included oxalic, malonic, succinic, and phthalic acid. Evolved ${ }^{14} \mathrm{CO}_{2}$ was trapped in $0.5 \mathrm{M} \mathrm{NaOH}$ and measured using liquid scintillation counting. Both noncomplexed and complexed acids degraded rapidly within the first 5 days for the Apl, Ap2 and BA soil horizons, with a considerably slower rate of degradation being observed in the Bt1 horizon. Similar trends were observed for the metal-complexed acids.

Percent degradation for noncomplexed acids ranged from 25 - 73\% and generally decreased with increasing soil depth. Metal-complexed acids demonstrated considerably less degradation, ranging from $12-40 \%$ for Al-complexes; 0.05 - $35 \%$ for $\mathrm{Cu}$-complexes and 0.36 - $25 \%$ for $\mathrm{Pb}$-complexes. Heavy metal complexation substantially reduced the quantity of organic acid degraded in all soil horizons, with acid degradation in the Bt1 horizon being essentially negligible.

\section{A Study of the Rare Earth Elements in Aqueous Carbonate and Chloride Systems}

\author{
FANNIN, Craig', EDWARDS, Robert', and KELLY, Eugene ${ }^{2}$ \\ 'Liverpool John Moores University, Byrom Street, Liverpool, L3 \\ $3 A F, U K$ \\ ${ }^{2}$ BNF Plc., Sellafield, Seascale, Cumbria, CA20 IPG, UK
}

Two of the most common man-made radiogenic elements, $\mathrm{Pu}$ and $\mathrm{Am}$, form ions of the same oxidation state and ionic radii as the rare earth elements (REE) $\mathrm{Ce}, \mathrm{Nd}$ and $\mathrm{Eu}$. Solubility and sorption studies can be carried out at much higher concentrations for the REE (or REE with actinide tracers) than for the actinides themselves. Plutonium and americium chemistry can be predicted through much larger concentration ranges using the REE without elaborate radiological safety precautions.

Detailed studies of the carbonate and chloride systems have established the major phases formed from direct precipitation of a selection of REE. Stability constants have been determined for these major phases and results will be presented for predicting solubilities of the major phases in radioactive waste disposal systems, with possible extrapolation to similar $\mathrm{Pu}$ and $\mathrm{Am}$ species.

In addition to stability studies, sorption experiments are being carried out on a selection of mineral phases typical of the repository near field and the geosphere, to determine the complete extent of REE removal from solution.

\section{Exposure to Platinum from Vehicle Catalytic Converters and Possible Health Implications}

\author{
FARAGO. M.E. ${ }^{\prime}$, THORNTON,.$^{\prime}$, KAZANTZIS, G. ${ }^{\prime}$, SIMPSON, \\ P.R. ${ }^{2}$ \\ 'Environmental Geochemistry Research Group, Centre for \\ Environmental Technology, Imperial College of Science \\ Technology and Medicine, London SW7 2BP, UK \\ ${ }^{2}$ British Geological Survey, Keyworth, Nottingham NG12 5GG, UK
}

This study considers human exposure to and possible health risks from platinum emissions from vehicle catalytic converters.

Vehicle exhaust catalysts became mandatory in the UK at the beginning of 1993 in response to the emission standards introduced in the EU, equivalent to those in the USA. Modern three way catalysts, which control $\mathrm{NO}_{\mathrm{x}}$ emissions as well as $\mathrm{CO}$ and $\mathrm{HC}$, typically contain $0.08 \% \mathrm{Pt}, 0.04 \% \mathrm{Pd}$ and $0.005-007 \% \mathrm{Rh}$. Evidence from a number of countries, including Germany, Sweden, USA and Britain, has shown that $\mathrm{Pt}$ in the environment has increased since the introduction of vehicle catalysts. Our work provides further evidence that $\mathrm{Pt}$ in road dusts is associated with traffic. Part of the $\mathrm{Pt}$ released into the air is deposited close to the roads and can be washed off by rain into rivers and coastal marine waters. Road dusts transported in storm water are eventually deposited as urban river sediments. Thus $\mathrm{Pt}$ from road dusts can be solubilized, enter waters, sediments, soils and the food chain. Some Pt compounds are known to be cytotoxic and have mutagenic and carcinogenic effects, and to have effects on microorganisms at very low concentrations. Platinum provides an example of the significance of speciation in metal toxicity. Metallic Pt appears to be biologically inert and non-allergenic. Platinum allergy, found in a number of susceptible precious metal workers, is confined to a small group of charged compounds that contain reactive ligand systems the most effective of which are $\mathrm{Cl}^{-}$ligands. It is evident that more information concerning exposure of the human population to platinum metals in water, air and foodstuffs and the health effects of such exposure is urgently required. 


\section{Identification of Arsenic-Rich Ground Water Using Geochemical Signatures and Geophysical Log Analysis, Albuquerque, New Mexico}

\author{
FINCH, Steven $T$. \\ John Shomaker \& Associates, Inc., 2703-D Broadbent Parkway, \\ NE, Albuquerque, New Mexico 87107, USA
}

From analysis of zoned ground-water sampling tests and geophysical logs, we have developed techniques for identifying the source and distribution of dissolved As produced from the Tertiary Santa Fe Formation sediments of the Albuquerque Basin. The initial investigation included correlation of As with chemical parameters that have not been considered in previous studies, and evaluation of theories for As source and distribution.

Findings from a more detailed investigation include the following: 1) The source of As is most likely associated with sediments eroded from nearby volcanic and igneous rocks containing As-bearing minerals, which are transported to a specific depositional environment and concentrated by sorption onto Fe oxyhydroxides. Sediments derived from these rocks may have been deposited as specific strata indicative of a particular depositional environment and time, 2) Subtle differences in the aquifer chemistry, resulting from water-rock reactions or chemical evolution, can influence the mobility of As. The chemical environments associated with :levated As may be identified by major-ion analysis, 3) As, $\mathrm{V}$, and $\mathrm{U}$ are commonly associated with the same source, and behave as dissolved constituents under similar chemical conditions. Elevated concentrations of dissolved As correlate with elevated concentrations of dissolved $\mathrm{V}$ from water produced from City of Albuquerque wells, and 4) In cases where elevated concentrations of As occur with elevated concentrations of $U$ in specific strata, then the strata could be identified by analysis of gamma-ray logs.

\section{Formation of Gossan and Oxidation of Sulfide Ores as Analogs of Oxidation of Tailings Piles}

\section{FLOHR, Marta J.K. and HAMMARSTROM, Jane M. U.S. Geological Survey, 954 National Center, Reston, VA 20192, USA}

Study of gossan and partly oxidized sulfide ore collected from mine waste dumps from the sediment-hosted Hazel Creek (chalcopyrite + sphalerite + pyrrhotite + galena) and Fontana (pyrrhotite + chalcopyrite + sphalerite + galena) copper mines, Swain County, North Carolina, will help us understand the weathering behavior of compositionally similar ores and metal mobility in tailings piles.

The relative reactivity of sulfide minerals in the partly oxidized ores is: pyrrhotite $\gg$ Se-bearing galena $>$ chalcopyrite, sphalerite. The relative reactivity of galena, chalcopyrite, and sphalerite is governed primarily by mineral associations. Mineralogical and compositional data (electron microprobe, scanning electron microscope, $\mathrm{X}$-ray diffraction) indicate that $\mathrm{Fe}, \mathrm{Cu}, \mathrm{Ag}$, and $\mathrm{Si}$ are concentrated and $\mathrm{S}$ and $\mathrm{Zn}$ are depleted during progressive oxidation and gossan formation. During the early stages of alteration: (1) pyrrhotite is most commonly replaced by marcasite and less commonly by Fe-oxyhydroxide and (2) Fe-oxyhydroxides [with minor $\mathrm{Cu}, \mathrm{Zn}$ (<2 wt. \% each), $\mathrm{Si}, \mathrm{Al}$, and (or) $\mathrm{S}$ ] form along grain boundaries of sulfides and gangue minerals (calcite, biotite, chlorite). During intermediate stages of alteration: (1) galena is partly altered and secondary $\mathrm{Pb}$ minerals (hinsdalite, anglesite?) form and (2) $\mathrm{Cu}$ is enriched relative to $\mathrm{S}$ with the formation of secondary $\mathrm{Cu}$-sulfide minerals that have a range of $\mathrm{Fe}, \mathrm{Zn}$, and (or) Se concentrations. Gossan, with no relict primary sulfides, consists of goethite \pm quart \pm hematite \pm (malachite + brochantite) \pm trace acanthite. Goethite contains minor $\mathrm{Cu}, \mathrm{Al}$, and $\mathrm{Si}$, but no detectable $\mathrm{Zn}$ or S. No secondary $\mathrm{Zn}$ minerals occur, consist with removal of $\mathrm{Zn}$ from the system. $\mathrm{Cu}$ is retained in some gossan as malachite and brochantite. Continued study of the altered sulfide ores will refine the mineralogical and chemical stages of weathering.

\section{Geochemistry and Human Selenium Imbalances in China}

FORDYCE ${ }^{I}$, F. M., ZHANG ${ }^{2}$, G., JOHNSON ${ }^{\prime}, C . C$., GE ${ }^{2}$, X., APPLETON ${ }^{\prime}, J$. D., ZHANG ${ }^{2}, Q$., $L I U^{2}, X$, and $L I^{2}, J$.

'British Geological Survey, Keyworth, Nottingham, UK. NGI2 $5 G G$ (BGS)

${ }^{2}$ Institute of Rock and Mineral Analysis, 26 Baiwanzhuang Street, Beijing 100037, China (IRMA)

Se is a naturally occurring non-metallic trace element which is essential to human and other animal health in small doses $(0.04 \mu \mathrm{g} / \mathrm{g})$ but is harmful in excess $(>4 \mu \mathrm{g} / \mathrm{g})$. China possesses one of the best epidemiological databases in the world on Se related diseases which has been used in conjunction with geochemical data to demonstrate a significant geological control on human Se exposure. Se deficiency in soils and crops has been linked to an endemic cardiomyopathy (Keshan Disease, KD), osteoarthropathic disorders (Kashin-Beck Disease) and esophageal cancer whereas selenium toxicity causes hair loss and nail deformation. However, the precise geographic areas at risk, the geochemical factors controlling environmental Se levels and human Se status are poorly defined and appropriate remediation strategies have yet to be established.

A multidisciplinary project involving the IRMA, the Chinese Ministry of Public Health and the BGS aims to devise a strategy for the prediction and remediation of Seresponsive diseases. Soil, grain, drinking water and human hair samples have been collected from three regions of China to investigate the relationships between environmental levels of Se and KD, oesophageal cancer and human selenosis. Within each region samples were collected from areas with high, moderate and low disease incidence. In the region of high $\mathrm{KD}$ incidence, levels of total Se in soil are 
higher than anticipated. Levels of Se in grain, water and hair decrease with increasing incidence of $\mathrm{KD}$ as expected. It is provisionally concluded that the $\mathrm{Se}$ in soils is complexed by organic matter and is thus unavailable to plants and the subsequent food chain

\section{Biotreatment of Metal Mine Waste Waters - Case Histories}

FRICKE, J., BLICKWEDEL, R., and HAGERTY, P.

Advanced GeoServices Corp., I0150 S. Centennial Parkway, Suite 400, Sandy, UT 84070, USA

For the past 10 years, mining companies have been involved in the biotreatment of metal mine waste waters. Several companies have either conducted their own research into the technology or have supported academic, governmental agencies, or private institutions. The biotreatment focus is on the use of sulfate reducing bacteria (SRB) for the biological reduction of sulfate to sulfide which produces a metal sulfide precipitate. The technology has undergone significant transformations; where in the past the technology was applied to abandoned or inactive mine sites, it has recently been applied to active mine sites, replacing conventional water treatment methods. This paper presents case histories of the evolution of the technology, from laboratoryscale to full-scale biotreatment projects. Water quality and engineering design data are presented for small scale $(1.0 \mathrm{ml}$ $\left.\mathrm{min}^{-1}\right)$ column tests up to full scale $\left(5,600 \mathrm{~L} \mathrm{~min}^{-1}\right)$ mine water treatment projects. Metal removal efficiencies for As, $\mathrm{Cd}, \mathrm{Cu}, \mathrm{Fe}, \mathrm{Mn}, \mathrm{Ni}$, and $\mathrm{Zn}$ are reported.

\section{The Behavior of $\mathrm{Cd}$ and $\mathrm{Hg}$ During Weathering of Sphalerite-Environmental Implications}

\section{FUGE, Ron, PERKINS, William T. and PEARCE, Nicholas J.G. Institute of Earth Studies, University of Wales, Aberystwyth, Ceredigion SY23 3DB, UK}

The many spoil heaps associated with abandoned $\mathrm{Pb} / \mathrm{Zn}$ mines in the mid-Wales ore field are frequently rich in the ore and gangue minerals which were mined. The mines have a long history of working, but peak production was in the period 1850 to 1870 . During the greater part of the working lives of the mines, sphalerite $(\mathrm{ZnS})$ was regarded as a gangue mineral and consequently is extremely enriched in many of the tips. Cadmium and $\mathrm{Hg}$ along with $\mathrm{Zn}$ make up group IIB of the periodic table, and both of these metals are found to be concentrated in sphalerite. Mid-Wales sphalerites contain between 0.095 and $0.52 \% \mathrm{Cd}$ and up to $50 \mathrm{mg} \mathrm{kg}^{-1}$ $\mathrm{Hg}$ in bulk samples. However, in the case of $\mathrm{Cd}$ it has been demonstrated that in highly weathered sphalerite fragments, $\mathrm{Cd}$ is relatively enriched in the surface regions. In addition, concentrations of this metal in fine-grained, ore-rich tips in mid Wales show enrichment relative to $\mathrm{Zn}$ so that the $\mathrm{Zn} / \mathrm{Cd}$ ratio is dramatically reduced to as little as 75 from between 120 and 665 in the original sphalerites.

In the present study, small fragments of sphalerites from tips have been analyzed by laser ablation ICP-MS using calibrations which were erected from powdered bulk samples of the mineral. Weathered surfaces of the sphalerites showed strong concentration of both $\mathrm{Cd}$ and $\mathrm{Hg}$ with values of over $2,800 \mathrm{mg} \mathrm{kg}^{-1} \mathrm{Cd}$ compared to about 1,500 $\mathrm{mg} \mathrm{kg}{ }^{-1}$ in unweathered material. Concentrations of $\mathrm{Hg}$ in weathered areas were as high as $700 \mathrm{mg} \mathrm{kg}^{-1}$ compared to $<50 \mathrm{~m} \mathrm{~kg} \mathrm{k}^{-1}$ in unweathered material. Similar data has been obtained for millimeter size fragments of sphalerite.

The concentration of the extremely toxic metals $\mathrm{Cd}$ and $\mathrm{Hg}$ in sphalerite grains exposed to weathering, and consequently in the tips which house them, is a major cause for concern in view of the ease with which the unvegetated tip material is prone to mobilization by fluvial and wind action.

\section{Temporal and Spatial Variations in the Chemistry of Ochres Derived from an Abandoned Metalliferous Mine}

\author{
FUGE, Ron and SPERRING, Timothy \\ Institute of Earth Studies, University of Wales, Aberystwyth, \\ Ceredigion $S Y 23$ 3DB, UK
}

Metal mining in mid Wales, U.K. dates back to the Bronze age with $\mathrm{Pb}$ and $\mathrm{Zn}$ the main metals sought, but with some $\mathrm{Cu}$ and $\mathrm{Ag}$ also won. The $\mathrm{Cwm}$ Rheidol mine situated some $14 \mathrm{~km}$ inland from the coastal town of Aberystwyth was a $\mathrm{Pb} / \mathrm{Zn}$ mine which ceased operation early this century. This mine has been a continuing source of contamination since its closure, the main problem being the large amount of pyrite and marcasite occurring in the gangue. These $\mathrm{FeS}_{2}$ minerals undergo oxidative weathering resulting in highly acidic mine effluent. Drainage from the mine, known locally as "the red stream", is heavily ochreous and contaminated with $\mathrm{Al}, \mathrm{Cd}$, $\mathrm{Ni}$, and $\mathrm{Zn}$. In an attempt to limit the serious contamination of the Afon Rheidol, which intercepts the mine drainage, a limestone filter was constructed in the 1960's to treat the acidic drainage. While this remediation measure was successful immediately following its construction, a build up of ochre has resulted in the filter having little effect on the $\mathrm{pH}$ and metal content of the water. Ochres deposited on the bed of the drainage stream and in the filter are strongly enriched in many of the contaminant metals which occur in the drainage, therefore, ochre precipitation is, to some extent a "self remediating" process. However, the ochres are themselves potential contaminants and it is necessary to ascertain their long term stability and the fate of the metals they contain.

In the present study, samples of ochre from the bed of the mine drainage stream and from the surface of the filter were collected at various times between May 1993 and June 1994. Analytical data for these samples show that there is considerable spatial and temporal change in ochre chemistry. Many of these changes can be related to varying Eh and $\mathrm{pH}$ 
conditions. A core from the surface of the filter showed that metal contents in the oxic surficial $4 \mathrm{~cm}$ were generally over $50 \%$ higher than in the more anoxic lower regions.

\section{Sulfate Adsorption Model for Predicting Soil Acidification}

\section{FUMOTO, Tamon \\ National Institute of Agro-Environmental Sciences, Kannondai 3- 1-1, Tsukuba, 305 Japan}

Numerous dynamic soil chemistry models have been published so far to predict soil acidification and to set "target loads" of acidity. Among various reactions incorporated in those models, $\mathrm{SO}_{4}$ adsorption by soil is a key process for assessing the impact of $S$ deposition. In most present models, however, $\mathrm{SO}_{4}$ adsorption is described as a function of $\mathrm{SO}_{4}$ concentration alone, not considering the effect of $\mathrm{pH}$. In this study, a simple function is presented to describe $\mathrm{SO}_{4}$ adsorption as a function of $\mathrm{pH}$ as well as $\mathrm{SO}_{4}$ concentration, based on experimental findings.

Experiments: Sulfate adsorption experiments were conducted on six surface soils (three Andosols derived from volcanic ash, two Brown Forest soils and one Yellow soil derived from granite). Two grams of soil were shaken with $30 \mathrm{ml}$ of solution containing $0-0.9 \mathrm{mmol} \mathrm{L}^{-1} \mathrm{CaSO}_{4}$ for 3 hours. In order to vary equilibrium $\mathrm{pH}, \mathrm{HCl}$ and $\mathrm{CaCl}_{2}$ were added to the initial solutions in 3 or 4 different $\mathrm{HCl} / \mathrm{CaCl}_{2}$ aatios. Amount of adsorbed $\mathrm{SO}_{4}$ was calculated from the change in solution $\mathrm{SO}_{4}$ concentration and the indigenous extractable $\mathrm{SO}_{4}$.

Results: For each soil, equilibrium $\mathrm{pH}$ was lowered about 1 unit from the native $\mathrm{pH}$ in 3 or 4 steps. For all soils, $\mathrm{SO}_{4}$ adsorption was significantly affected by $\mathrm{pH}: 1$ unit decrease in equilibrium $\mathrm{pH}$ increased adsorbed $\mathrm{SO}_{4}$ by 30 $40 \%$. Moreover, $\mathrm{SO}_{4}$ adsorption varied tremendously among individual soils: when shaken with $0.9 \mathrm{mmol} \mathrm{L}^{-1}$ $\mathrm{CaSO}_{4}$ solution, one Andosol adsorbed more than $20 \mathrm{mmol}$ $\mathrm{SO}_{4} \mathrm{~kg}^{-1}$, whereas the Yellow soil adsorbed less than 2.0 $\mathrm{mmol} \mathrm{SO}_{4} \mathrm{k}^{-1}$. However, the amounts of adsorbed $\mathrm{SO}_{4}$ were modeled quite well for all soils by non-linear least square method using the following equation:

$$
\mathrm{Q}=\mathrm{K}\left[\mathrm{H}^{+}\right]^{\mathrm{m}} \mathrm{C}^{\mathrm{n}}
$$

where

$\mathrm{Q}=$ Amount of adsorbed $\mathrm{SO}_{4}\left(\mathrm{mmol} \mathrm{kg}^{-1}\right)$

$\mathrm{C}=$ Equilibrium $\mathrm{SO}_{4}$ concentration $\left(\mathrm{mmol} \mathrm{L}^{-1}\right)$

$\mathrm{K}, \mathrm{m}, \mathrm{n}=$ Parameters determined on each soil Hence, equation ( 1 ) is considered as a useful function for describing $\mathrm{SO}_{4}$ adsorption by soils in practical ranges of $\mathrm{SO}_{4}$ concentration and $\mathrm{pH}$.

\section{Environmental Geochemistry of Rare Earth Elements in a Typical Landscape in Jiangxi, Southern China}

\author{
GAO, Xiaojiang', ZHANG, Shen', WANG, Yuqi', WANG, Lijun', \\ and LIU, Shujuan' \\ 'Institute of Geography, Chinese Academy of Sciences, Beijing \\ 100101 \\ ${ }^{2}$ Institute of High Energy Physics, Chinese Academy of Sciences, \\ Beijing 1001080
}

The abundance of rare earth elements (REE) is high in the geochemical landscape of the REE mining area, southern Jiangxi, China. In this paper, the distribution, fractionation, and speciation of REE were studied in a typical geochemical landscape. Samples of soil, weathering rock and plants were collected from three landscape profile types (eluvial landscape, leaching accumulative landscape, and hydromorphic landscape). The REE content in the hydromorphic landscape is higher than that in the eluvial landscape and leaching accumulative landscape. The REE chondritenormalized patterns are identical to parent rock, with strong Eu depletion. However, the fractionation between light REE and heavy REE, and Ce abnormality occur in the geochemical landscape, which is mainly controlled by the $\mathrm{pH}-\mathrm{Eh}$ conditions during weathering and the physical-chemical properties of the REE.

In order to investigate REE mobility and ecological effects, the speciation of REE was studied. Results suggested that REE exist mainly in water soluble, exchangeable and loosely bound to organic matter forms, so REE are mobile, easy to remove and can be accumulated in plants and crops, which may affect the ecological environment and health.

\section{Some Methods for Estimating Phytoavailable Cadmium in Prairie Soils}

\author{
GARRETT', Robert G., MACLAURIN', Alice I., GREEN Carrie \\ E., CHANEY', Rufus L., and HALL', Gwendy E.M. \\ ${ }^{\prime}$ Geological Survey of Canada, 601 Booth St., Ottawa, ON, \\ Canada K1A OE8 \\ ${ }^{2}$ U.S. Dept. of Agriculture, ARS, Beltsville, MD 20705, USA
}

A suite of soil and filled grain samples from sites representative of the major soil series in all counties of North Dakota were collected in late summer 1994 by the U.S. Department of Agriculture. The soils, from $0-15 \mathrm{~cm}$ depth, correspond to the rooting zone for durum wheat. A subset of 164 sites representing the counties and soil series was selected for geochemical studies to determine soil chemical factors influencing cadmium uptake by durum wheat. The $<2 \mathrm{~mm}$ fraction of the soil was recovered and analyzed for DTPA, $\mathrm{Na}_{4} \mathrm{P}_{2} \mathrm{O}_{7}$ and $\mathrm{NH}_{4} \mathrm{Cl}$ extractable $\mathrm{Cd}$. In addition, $\mathrm{pH}$, total and solubilized organic carbon, and other relevant soil parameters were determined. The $\mathrm{Cd}$ content of durum wheat was determined following a total dissolution of the 
grain. The results confirm the important role that soil $\mathrm{pH}$ and organic content have in influencing $\mathrm{Cd}$ uptake through their control of $\mathrm{Cd}$ mobility and sequestration. Non-linear multivariate regression models have been investigated in order to provide quantitative estimators of potential $\mathrm{Cd}$ uptake by durum wheat based on soil properties. Successful models are described whose predictive variates are candidates for systematic measurement in order to prepare maps of Cd uptake hazard that would assist agronomists in recommending appropriate $\mathrm{Cd}$ uptake minimization strategies to farmers.

\section{Relationship Between Alzheimer's Disease and Aluminum Speciation in Drinking Water: A Case-Control Study in Saguenay- Lac-St-Jean, Quebec (Image Project)}

\author{
GAUTHIER, E. ${ }^{\prime}$, FORTIER, I. ${ }^{2}$ COURCHESNE, F. ${ }^{l}$ PEPIN, ${ }^{2}{ }^{2}$, \\ MORTIMER, J. ${ }^{3}$, GAUVREAU, D. ${ }^{2}$. \\ 'Departement de Geographie, Universite' de Montreal, Quebec, \\ Canada \\ ${ }^{2}$ Algene Biotechnologies Corporation, Quebec, Canada \\ ${ }^{3}$ University of Tampa, Institute of Aging, Florida, USA
}

The relationships between Alzheimer's disease (AD) and aluminum (Al) speciation in drinking water were evaluated using a case-control study. A total of 87 cases and 87 controls aged $>70$ years and matched for age and sex were studied using rigorous test and diagnostic criteria. The residential histories of the subjects were used to determine the individual lifetime exposure (birth to onset). The longterm exposure was established by measuring $\mathrm{Al}$ concentration and speciation (monomeric organic, monomeric inorganic, polymeric forms) for 54 cities of the SaguenayLac-St. Jean area in Quebec. The statistical analyses involved the use of logistic regressions adjusted for confounding variables (education level, presence of family cases, ApoE M4, $\mathrm{Si}$ ) for calculating the odds ratios (OR). The results showed that long-term exposure to $\mathrm{Al}$ in drinking water could have a significant neurotoxic effect. For the period between 0 to 50 years before onset, exposure to total dissolved $\mathrm{Al}$ (Altd) concentrations exceeding $\sim 1.58 \mu \mathrm{mol} \mathrm{L}^{-1}$ resulted in an OR of 2.54 (1.06-6.13). For the same period, exposure to a polymeric $\mathrm{Al}(\mathrm{Alp})$ concentration exceeding $\sim 0.65 \mu \mathrm{mol} \mathrm{L}^{-1}$ gave an OR of 3.27 (1.29-8.31). For the period $>50$ years before onset, only monomeric organic $\mathrm{Al}$ (Almo) with a concentration exceeding $\sim 0.55 \mu \mathrm{mol} \mathrm{L}^{-1}$ seemed to be a risk factor for AD with an OR of 2.44 (1.085.48). Thus, our results demonstrate that the estimation of Al speciation must be done with an analytical method to fractionate the $\mathrm{Al}$ into its various species rather than by simple statistical relationships between $\mathrm{Al}$ and ligands. Finally, long-term exposure to Altd, Alp and Almo in drinking water together with genetic disposition could be important risk factors of $\mathrm{AD}$.

\section{Behavior of Polycyclic Aromatic Hydrocarbons in Soil Ecosystems}

\author{
GENNADIYEV, A., KOZIN, I., PIKOVSKII, Yu., and \\ TEPLITSKAYA, T. \\ Faculty of Geography, Moscow State University, Moscow 119899, \\ Russia
}

The behavior of heavy polycyclic aromatic hydrocarbons $(\mathrm{PAH})$ and low-nuclei aromatic structures displays a distinct trend. The heavy PAH accumulate in the topsoils, whereas low-nuclei molecules are distributed more regularly in soil profile. Mobility of the PAH decreases with increasing molecular mass. This phenomenon has been observed in podsolic soils (glossudalfs), chestnut soils (calciustolls), chernozems (haplborols), and solonetzes (natriboralfs). The PAH redistribution within the soil profile becomes more evident if relative parameters such as the hydrocarbonhumus index are used. In addition to the direct impact of pollution sources, PAH concentrations in soils are affected by the lateral redistribution of contaminants in accordance with micro- and mesorelief features. The most heavily polluted soils are usually restricted to sinks. Soils of eluvial and trans-eluvial sites are less susceptible to pollution owing to the downslope removal of pollutants by surface and soil run off. Since the composition of PAH in soils is responsive to changes in the ecological and functional status of the soil, PAH may indicate soil degradation and progradation. Thus it seems possible to propose a conventional parameter for the relative biotransformation potential of soils - the ratio of concentrations of complex alkylated phenanthrenes (biogenic PAH) to allochtonous unsubstituted PAH (technogenic ones), which, to a certain extent, is a reflection of the intensity of reworking by soil biota of the organic pollutant fluxes. Data on the changes of this ratio with time are very informative.

\section{Environmental Impacts of Lignite Opencast Mining Areas in Eastern Germany}

\author{
GLÄSSER, Walter' and GLÄSSER, Cornelia ${ }^{2}$ \\ ' Department of Hydrogeology, Environmental Research Centre, \\ Leipzig/Halle, Germany \\ ${ }^{2}$ Institute of Geography, Martin Luther University, Halle, \\ Germany
}

Lignite has been mined for more than 100 years in what is now Eastern Germany. It has been used as source for of energy and also as raw material for the chemical industry. Between 1951 and 1990 lignite was extracted in very large opencast mines $(330,000,000 \mathrm{t}$ in 1988 alone). As of 1990 only $20 \%$ of the mines are still active.

The Tertiary sediments are rich in pyrite and marcasite content. Oxidation of the pyrite results in acidification of surface and ground water ( $\mathrm{pH} 2.0$ to 4.0). Hydrological problems (quality, quantity, rate and amount of refilling water from varies sources) are associated with the rise back of ground water and lake water collecting in the abandoned 
opencast mine. In addition geotechnical and hydrochemical problems exist. Acid water leads to mineral solution and change of physical soil properties. Vast amounts of heavy metals, metalloids and aluminum are dissolved and slope stability is altered. As the aquifers refill the disturbance of the hydrological system, including lower Triassic - and Permian aquifers, brings about a mixture of waters differing widely in age and in mineralization as the aquifers refill and the water accumulates dissolved solids $(\mathrm{Cl}$ from 500 to $60,000 \mathrm{mg} \mathrm{L}^{-1}, \mathrm{SO}_{4}^{2-}$ from 1,000 to $>3,000 \mathrm{mg} \mathrm{L}^{-1}$ ).

The current investigation aims to describe the situation, understand this complex hydrochemical system and develop new and nonaggressive reclamation procedures.

Hydrochemical and geochemical analysis, hydrological isotope investigation and microbiological methods are used. The quality and quantity of impacts and detrimental consequences are shown and a balance sheet of the material flow presented. Various multispectral remote sensing data in combination with a GIS will be used for monitoring environmental impacts.

\section{Multimedia Environmental Geochemical Mapping Using Field Portable X-Ray Fluorescence}

\author{
GLANZMAN, Richard K. and CLOSS, L. Graham. \\ Colorado School of Mines, Golden, Colorado 8040I, USA
}

Technological developments in design and capabilities of field portable $x$-ray fluorescence (FPXRF) instruments and laptop computers allow geochemical mapping in real time in the field. Case studies in mining areas demonstrate the application of this technology to geochemical assessment of soils, tailings, sediments, slags, precipitates, and vegetation. FPXRF instruments provide in situ geochemical definition of the nature and extent of elements and their geochemical associations. They permit identification and collection of representative samples for subsequent confirmation by laboratory analyses focused solely on essential elements. This strategy allows for the selection of the most appropriate media, eliminates the need for multiple sampling episodes, avoids potential variations due to seasonal changes, and minimizes determination of unnecessary elements by multiple laboratories.

The case studies include work in the Leadville Mining District, Colorado; the Tri-State District, Kansas; and the Butte District, Montana. The investigation of a broad spectrum of mining waste types resulted in a quantitative, cost-effective appraisal of specific element concentrations and their mobility. These cases also involved complementary remote sensing investigations. Integration of the two investigative methods permitted an evaluation of metal concentrations in vegetation (phytotoxicity) and soil. Cost ;avings were approximately one-third to three-quarters that of essentially the same work performed by conventional environmental sampling and analysis programs.

\section{Weathering and Colloid Mobility as Factors Influencing the Migration of Radioactive Elements at Steenkampskraal Mine in the Northern Cape Province, South Africa}

\author{
GLENDINNING, John., WILLIS, James P., and FEY, Martin V \\ Dept. of Geological Sciences, University of Cape Town, \\ Rondebosch, 7700, South Africa
}

The Steenkampskraal mine is located in a semi-arid region in the southwest part of South Africa and $100 \mathrm{~km}$ south of Vaalputs, the South African low and intermediate level radioactive waste disposal facility. Because of its location in similar terrain to Vaalputs, Steenkampskraal is being used as a field analogue of Vaalputs, which authorities are seeking to upgrade to a high-level waste disposal site.

Steenkampskraal is the richest monazite ore body in the world, containing $45 \%$ rare earth oxides, together with $4 \%$ $\mathrm{ThO}_{2}, 600 \mathrm{mg} \mathrm{kg}^{-1} \mathrm{U}_{3} \mathrm{O}_{8}$ and $\sim 1 \% \mathrm{Cu}$ as sulfides (chalcopyrite), which produces acid drainage when in contact with air and water. Of concern is the possible leaching and movement of transuranic elements from the waste material through ground water. Evidence was required as to the role of ground-water colloids in the mobilization and retardation of actinides. Ground waters, mine waters and acid leachate were analyzed by ICP-MS for REEs, Th and $U$ to determine element concentrations, and to assess the extent of $U$, Th and REE transport away from the primary ore body under in situ conditions. The program MINTEQA2 was used to model the speciation of elements in the water samples. Borehole waters containing suspended colloids (including lepidocrocite, mica and kaolinite) had enhanced Th, $\mathrm{U}$ and REE concentrations in filtrates of acidified ( $\mathrm{pH} \sim 2)$ samples, suggesting that colloid migration may be important in dispersal of these elements.

\section{Organic Substances in Migratory Processes of Radionuclides}

\author{
GOLOVKO, Natalia V., ROZKO, Alla N., and \\ KOROMYSLICHENKO, Taisia I. \\ 34 Palladin Ave, Kyiv, UA 252680, Ukraine
}

The accident at the Chernobyl Nuclear Power Plant (CNPP) in 1986 brought about a unique research opportunity for mankind. Large areas of Ukraine, Belarus immediately adjacent to the CNPP and some areas in Europe and Asia, were contaminated with radionuclides and the fallout was observed practically all over the Earth. The existing principles and methods of decontamination of polluted lands do not take into account the specificity of environmental conditions, particularly regarding radionuclide mobilization and transfer. One of the components of decontamination is consideration of the ability of radionuclides for long-term fixation (localization by components of natural landscapes). Organic compounds (humic acids) are important complexers of radionuclides. At the same time, the most mobile 
components of the soil humus- fulvic acids not bound with calcium and clay minerals - have considerable effect on the migration of radioactive strontium and cesium. Among the thousands of technogenic organic substances-pollutants of soils and water-- oil products assume a special place as substances with increased toxicity and a low limiting concentration $\left(0.05 \mathrm{mg} \mathrm{L}^{-1}\right)$. Oil products act as transfer agents for radionuclides resulting in a noticeable deterioration of the environment. By analyzing the content of oilproducts in soils, as well as in water, one can predict the state of the ecology in different regions which have been contaminated by radionuclides. Interaction of organic components of soils with technogenic contamination is the most important part of the problem of the ecological capacity of a system, its ability to decontaminate, and the possibility of using technical means for rehabilitation of contaminated territories.

In the present work an attempt was made to estimate the role of natural and technogenic organic compounds in the migration of ${ }^{90} \mathrm{Sr}$ and ${ }^{137} \mathrm{Cs}$ in soils, and ground and surface waters of the main ponds of the Ukraine. During the experiment the following methods were used: (1) Chemical methods of extraction, selection and separation of humic substances and oil-products; (2) Gel-chromatographic; (3) Photocolorimetric; (4) IR-spectrometric; (5) $x$-ray powder diffraction.

The work shows that the geochemical behavior of radionuclides is largely determined by its physico-chemical form. Radiocesium, bounded with the most water-soluble part of organic compounds in soil - fulvic acids - ranges from 0.47 to $27.8 \%$ of the total, the remainder is in a fixed state and is bounded with humic acids and clay minerals. The activity of ${ }^{137} \mathrm{Cs}$ is accumulated in the upper layer $(0-2)$ $\mathrm{cm}$ of the soils and is correlated with large amounts of humic acids, enriched with carboxyl groups. Strontium is present in water mostly in a form of intricate complexes, but not in a form of individual compounds with organic substances of an unspecified nature and humic acids. The mobility of strontium is dependent on the solubility of its compounds in soil and water.

\section{Heavy Metals in Soils of the Sabana de Bogotá, Colombia}

\section{GONZALEZ, Luz Miryan, and VARGAS, Orlando INGEOMINAS, Diagonal 53 No. 34-53, Bogotá, Colombia}

Sabana de Bogotá is a plain with an area of $4,500 \mathrm{~km}^{2}$, that surrounds the capital city of Colombia with about 6 million inhabitants. In this area, soils are dedicated to agricultural and cattle feeding activities. Water from the Bogotá River is used for irrigation. This river goes through the Sabana from south to north receiving domestic and industrial residues without any treatment in most of the cases. Previous studies have found high levels of heavy metals in its water and bottom sediments.

In this study soils were evaluated using the aqua regia extractable, mobilizable (AAAcEDTA) and mobile
(NH4OAc, $1 \mathrm{~N}, \mathrm{pH}$ 7) fractions of $\mathrm{Cd}, \mathrm{Co}, \mathrm{Cr}, \mathrm{Cu}, \mathrm{Mn}, \mathrm{Ni}$, $\mathrm{Pb}, \mathrm{Zn}, \mathrm{Mo}, \mathrm{As}$ and $\mathrm{Hg}$ in soils were evaluated using ICP-AES, ET-AAS and HG-AAS. An ANOVA statistical design was used to select sampling sites in a area of 800 $\mathrm{km}^{2}$, from cells $10 \mathrm{~km}$ to $0.2 \mathrm{~km}$ on side. A soil sample of each horizon found was taken until the $C$ horizon or water was reached. A total of 166 samples were taken.

High levels of Cd $\left(0.1-13.1 \mathrm{mg} \mathrm{kg}^{-1}\right)$, Co $(0.05-37 \mathrm{mg}$ $\left.\mathrm{kg}^{-1}\right), \mathrm{Cr}\left(5-12 \mathrm{mg} \mathrm{kg}^{-1}\right), \mathrm{Cu}\left(2-204 \mathrm{mg} \mathrm{kg}^{-1}\right), \mathrm{Ni}(10-745$ $\left.\mathrm{mg} \mathrm{kg}^{-1}\right)$ and in some cases $\mathrm{Pb}\left(5-176 \mathrm{mg} \mathrm{kg}^{-1}\right)$ and $\mathrm{Hg}$ $\left(0.01-1.2 \mathrm{mg} \mathrm{kg}^{-1}\right)$ were found in localized sites indicating a health risk for the population that consumes the crops grown in these soils.

\section{Effect of Industrial Effluents on Trace Element Mobility in Soil}

GOVIL, P.K.

National Geophysical Research Institute, Hyderabad-500007, INDIA.

Detailed studies were carried out at Nacharam Lake, Hyderabad, India to study the geochemical environment and effect of industrial pollution on trace elements. Nacharam lake is surrounded on two sides by an Industrial Development Area having many different kinds of industries. Many industries are releasing their treated and untreated effluent into the lake. On the other side of the lake, housing colonies are releasing their sewage into the lake.

Lake sediment samples were collected from different parts of the lake in the month of May when the lake water recedes. The samples were analyzed for their major, minor and trace elements by X-ray Fluorescence Spectrometer and Inductively Coupled Plasma Mass Spectrometer. Soil samples were collected from different depths, to as much as $100 \mathrm{~cm}$, to find out whether the source of heavy metals was anthropogenic or part of the natural geochemical environment.

It was found that most of the trace metals in the soil/ sediment samples were above the tolerance limit; $\mathrm{Pb} 100$ $260 \mathrm{mg} \mathrm{L}^{-1}, \mathrm{Zn} 500 \mathrm{mg} \mathrm{L}^{-1}, \mathrm{Sr} 530 \mathrm{mg} \mathrm{L}^{-1}, \mathrm{Cu} 385 \mathrm{mg} \mathrm{L}^{-1}, \mathrm{Ba}$ $2200 \mathrm{mg} \mathrm{L}^{-1}$, Ni $200 \mathrm{mg} \mathrm{L}^{-1}, \mathrm{P}_{2} \mathrm{O}_{5} 2.3 \%$ and are of anthropogenic origin. The surrounding rocks are predominantly granites and these high concentrations can not be derived from these rocks. Abnormally high concentrations of $U$ ( 25 $\left.\mathrm{mg} \mathrm{L}^{-1}\right)$ and $\mathrm{Th}\left(60 \mathrm{mg} \mathrm{L}^{-1}\right)$ were also observed. These radiogenic elements are of natural origin being derived from the surrounding rocks which is an abnormal but common feature in and around Hyderabad. The heavy metals in the soil mix with organic acids present in the soil (such as humic and fulvic acid) and form complexes which help them to migrate in soils and leach out to contaminate ground-water resources. Some of the toxic trace metals are absorbed by leafy vegetables and find their way to humans through the food chain causing a health hazard. 


\section{Acid/saline Ground Waters in the Southern Yilgarn Craton, Western Australia}

GRAY, David J.

CRC Landscape Evolution and Mineral Exploration, CSIRO Exploration and Mining, Underwood Ave. Floreat, WA 6014 Australia

Much of the area of the Yilgarn Craton in Western Australia is presently arid to semi-arid, with little flowing or standing waters. Ground waters are at depths of $30-60 \mathrm{~m}$ in a deep regolith of weathered rock and transported overburden, and shallower in the valleys. In the southeast of the Yilgarn Craton, including the Au and Ni mining centers of Kalgoorlie and Kambalda, ground waters are saline to hypersaline, and commonly have $\mathrm{pH}$ values of $3-4.5$. These ground waters are significantly enriched in a wide range of elements including $\mathrm{Au}$ (up to $4 \mu \mathrm{g} \mathrm{L}^{-1}$ ), transition metals (e.g., up to: Co 1.2, Cu 0.6, Ni 1.3, $\mathrm{Zn} 1.1 \mathrm{mg} \mathrm{L}^{-1}$ ), $\mathrm{Pb}$ (up to $2.1 \mathrm{mg} \mathrm{L}^{-1}$ ), $\mathrm{U}$ (up to $0.44 \mathrm{mg} \mathrm{L}^{-1}$ ) and rare earth elements (REE) (up to: $\mathrm{La} 2.5, \mathrm{Ce} 3.5$, total REE $7 \mathrm{mg} \mathrm{L}^{-1}$ ).

Gold dissolves in these ground waters as a halide (chloride or iodide) complex. Formation of these complexes requires highly oxidizing conditions, and measured oxidation potentials (Eh) of shallow ground waters commonly reach $850 \mathrm{mV}$. These conditions are probably due to equilibration with the $\mathrm{Mn}^{2+} / \mathrm{Mn}_{\mathrm{x}} \mathrm{O}_{\mathrm{y}}$ redox couple. Dissolved $\mathrm{Au}$ concentrations increase with $\mathrm{Eh}$, and show a very strong antipathetic relationship to dissolved $\mathrm{Fe}$, due to the redox reaction between these phases:

$\mathrm{AuCl}_{2}{ }^{-}+\mathrm{Fe}^{2+}+3 \mathrm{H}_{2} \mathrm{OPA} \mathrm{Au}_{(S)}+\mathrm{Fe}(\mathrm{OH})_{3(S)}+2 \mathrm{Cl}^{-}+3 \mathrm{H}^{+}$ These processes can explain the major depletion of $\mathrm{Au}$ in the upper part of the weathered profile, and the accumulation of secondary Au in (sub-) horizontal zones at depth.

Enrichment of other metals in ground water does not appear to be related to mineralization, but instead is due to evaporitic concentration, following leaching from the country rocks. Indeed, various bivariate or multivariate plots of dissolved metal concentrations may be used to identify the rock in contact with the ground water, even where the bedrock is highly weathered. The REE concentrations appear to be greater than others recorded elsewhere in the world. It is calculated that water pumped from one palaeodrainage system for use in a single Au processing operation contained $4.2 \mathrm{t}$ total REE per annum.

\section{Source Chemistry and Characteristics of Intermittent Stream Waters Having Low pH and Elevated Metal Concentrations, Patagonia Mountains, Santa Cruz County, Arizona}

\author{
GRAY, F. ${ }^{\prime}$, CHAFFEE, M. ${ }^{2}$, WIRT, L. ${ }^{\prime}$, LICHTE, $F^{2}{ }^{2}$, and \\ CARUTHERS, K.' \\ 'U.S. Geological Survey, 520 N. Park Avenue, Suite 355, Tucson, \\ Arizona 87519, USA \\ ${ }^{2}$ U.S. Geological Survey, Federal Center, MS 973, Denver, \\ Colorado 80225, USA
}

Surface waters in predominantly intermittent streams were sampled in the Patagonia Mountains, Arizona, from the fall of 1996 to the winter of 1997 in order to: (1) characterize water quality in a semi-arid mountain environment with known sources of potentially toxic metals; (2) identify sites having streamflow with low $\mathrm{pH}$ and elevated metal concentrations; (3) evaluate the streamflow with respect to distance downstream and evaluate metal-loading characteristics during periods of low flow, post- storm runoff, and receding snow melt; and (4) compare, within selected drainage basins, the metal concentrations of the streamflow with those of near-surface or surficial materials; including unaltered outcrops, weathered and(or) mineralized outcrops, soils, mine dumps and tailings.

Areas selected for this study include the drainage basins for Harshaw Creek, Mowry Wash, Sonoita Creek, and the upper part of the Santa Cruz River basin in the San Rafael Valley. Numerous mines, prospects, waste dumps, and tailing piles are abandoned within these basins, but large parts of the region are mineralized and remain largely undisturbed. Altered but unmined exposures, such as those areas around Red Mountain and the northwest slope of the Patagonia Mountains, contain extensive quartz-sericitepyrite and clay alteration zones. The areas around Red Mountain and the 4-Metals and Sunnyside mines contain significant deposits of ferricrete that are related to low-pH fossil streams. Both mined and unmined areas produce waters with $\mathrm{pH}$ values as low as 2.7 , and elevated concentrations of metals. Preliminary values of dissolved trace metals in streamflow range from 0.7 to $12.4 \mathrm{mg} \mathrm{L}^{-1}$ of $\mathrm{Cu}, 0.33$ to $11.4 \mathrm{mg} \mathrm{L}^{-1} \mathrm{As}, 0.2$ to $10.4 \mathrm{mg} \mathrm{L}^{-1} \mathrm{~Pb}$, and 2.1 to $60 \mathrm{mg} \mathrm{L}^{-1}$ of $\mathrm{Zn}$. Mine tailings are a significant source of suspended sediment during infrequent storms and contain potentially acid-generating materials; however, springs and seeps related to fractures in the mineralized outcrops may also contribute to the dissolved chemistry.

During typical, prevailing, low-flow conditions, acidic streamflow at higher elevations is intermittent and does not connect to larger drainages downstream. For example, on July 23,1997 , a pH value of 3.4 was measured from a small perennial reach in upper Flux Canyon. Streamflow continued approximately 0.8 kilometers before disappearing beneath the streambed. Base flow reappeared 4 kilometers downstream having a $\mathrm{pH}$ value of 7.3. Continued investigations will attempt to address whether this and other observa- 
tions of large variations in $\mathrm{pH}$ in other drainages can be attributed to (1) chemical reactions along the flowpath, such as buffering from carbonates, (2) dilution from other groundwater sources, or (3) the possibility that water moving downgradient from the upper to the lower reaches is not hydrologically connected except during periods of runoff. Further studies will evaluate whether acidic waters from mineralized and mined areas are neutralized downstream primarily by secondary calcite or detrital volcanic materials present in active streambed alluvium and shallow basin-fill deposits. During low-flow conditions, acid-base redox reactions involving manganese and iron, and sorption reactions promote the neutralization of low-pH waters. Buffering reactions appear to be more effective in an arid climate than in other study locations having greater precipitation.

\section{Environmental Geochemistry and Mercury Speciation of Abandoned Mercury Mines in Southwestern Alaska}

GRAY, John E.

U.S. Geological Survey, P.O. Box 25046, MS 973, Denver, CO 80225, USA

Abandoned mercury mines and mercury-rich deposits are scattered over several thousand square kilometers in southwestern Alaska. The deposits generally consist of epithermal veins and vein breccias containing abundant cinnabar and stibnite with minor realgar, orpiment, and native mercury. About 40,000 flasks of mercury have been produced from mines in this region. Because mercury is a heavy metal that can be toxic to humans, these abandoned mines are of public concern. Concentrations of total mercury and methylmercury were measured in stream sediment, stream water, and fish collected downstream from several mines to evaluate mercury accumulation and were found to contain highly elevated mercury concentrations compared to mercury in samples collected from background sites. Stream-sediment samples collected near the mines contain abundant cinnabar and as much as $5,000 \mu \mathrm{g} \mathrm{g}^{-1} \mathrm{Hg}$. Stream-water samples generally contain mercury concentrations below the $2 \mu \mathrm{g} \mathrm{L}^{-1}$ drinking-water standard recommended by the State of Alaska. The concentration of mercury is several times higher in unfiltered stream-water samples than in filtered water samples, indicating that suspended mercury is dominant. Speciation studies indicate that methylmercury concentrations in stream-sediment and stream-water samples is low, generally less than 1 percent of the total mercury. Fish contain as much as $0.6 \mu \mathrm{g} \mathrm{g}^{-1} \mathrm{Hg}$ (wet weight in muscle), but methylmercury generally comprises greater than 90 percent of the total mercury, which is typical of freshwater fish. Although elevated, all mercury concentrations in fish are below the $1 \mu \mathrm{g} \mathrm{g}^{-1}$ action level recommended for edible fish.

\section{Environmental Studies of Mineral Deposits in Alaska}

GRAY, John E., KELLEY, Karen D., GOLDFARB, Richard J., TAYLOR, Cliff D.

U.S. Geological Survey, P.O. Box 25046, MS 973, Denver, CO 80225, USA

Geochemical studies characterize the natural and humaninduced environmental effects associated with several mineral deposits in Alaska. Baseline studies of unmined shale-hosted massive sulfide deposits in northern Alaska illustrate the importance of mineralogy, ore grade, and host rock lithology on surface water compositions. Natural stream waters draining $\mathrm{Fe}$ - and $\mathrm{Zn}$-rich deposits have low $\mathrm{pH}$ (2-3) and high concentrations of $\mathrm{Fe}\left(230,000 \mu \mathrm{g} \mathrm{L}^{-1}\right)$ and $\mathrm{Zn}$ $\left(>40,000 \mu \mathrm{g} \mathrm{L}^{-1}\right)$. Carbonate alteration minerals associated with some deposits buffer the acidity of water to near-neutral $\mathrm{pH}$ and reduce metal concentrations. Waters draining mined volcanogenic massive sulfide deposits in Prince William Sound are acidic $(\mathrm{pH}=2.6)$ with elevated concentrations of $\mathrm{Fe}\left(20,000 \mu \mathrm{g} \mathrm{L}^{-1}\right), \mathrm{Cu}$, and $\mathrm{Zn}$ (as much as 5,000 $\mu \mathrm{g} \mathrm{L}^{-1}$ ). Studies of gold vein deposits in southern Alaska show that mine drainage is generally alkaline $(\mathrm{pH}=6.4-8.0)$ with low metal concentrations, but high dissolved As (as much as 130 $\mu \mathrm{g} \mathrm{L^{-1 }}$ ). Stream-waters draining abandoned $\mathrm{Hg}$ mines in southwestern Alaska have $\mathrm{pH}$ values of 7-8.5 and as much as $2.5 \mu \mathrm{g} \mathrm{L}^{-1} \mathrm{Hg}$. Stream-sediment samples contain abundant cinnabar and high $\mathrm{Hg}$ concentrations (as much as $5,000 \mu \mathrm{g}$ $\left.\mathrm{g}^{-1}\right)$. Fish collected near the mines contain as much as $0.6 \mu \mathrm{g}$ $\mathrm{g}^{-1} \mathrm{Hg}$ (wet weight), which are elevated relative to backgrounds, but are below the recommended level of $1 \mu \mathrm{g} \mathrm{g}^{-1}$ $\mathrm{Hg}$ for edible fish. Surface waters draining a chromite mine in southern Alaska are near-neutral $(\mathrm{pH}=7-8)$ and contain low concentrations of $\mathrm{Cr}\left(0.5\right.$ to $\left.1.0 \mu \mathrm{g} \mathrm{L}^{-1}\right)$. These types of environmental studies are useful for (1) determining natural background conditions, (2) identifying hazardous abandoned mine sites, and (3) predicting the environmental effects of future mineral resource development.

\section{Mobilization of Lead from Maternal Skeleton during Pregnancy}

\author{
GULSON, Brian L.' , JAMESON, C.W. ${ }^{2}$, MAHAFFEY, Kathryn \\ $R^{3}{ }^{3}$, MIZON, Karen J. ', and KORSCH Michael J.' \\ 'Macquarie University \& CSIRO/EM, Division of Exploration \\ Geoscience, P.O. Box I36, North Ryde, NSW, Australia \\ ${ }^{2} \mathrm{NIEHS}$ \\ ${ }^{3} E P A / C A O, U S A$
}

The question of the extent of $\mathrm{Pb}$ mobilization from the maternal skeleton during pregnancy and lactation is one of the most outstanding problems of $\mathrm{Pb}$ toxicity. We have undertaken a longitudinal cohort study in an urban environment of European female immigrants of child-bearing age (18-35 years) to Australia whose skeletal $\mathrm{Pb}$ isotopic composition has been determined to be different from that in their current environment. High precision $\mathrm{Pb}$ isotopic 
compositions and $\mathrm{Pb}$ concentrations are measured on: maternal blood and urine prenatally, monthly during gestation and postnatally for 6 months; infant blood and urine for 6 months; and environmental measures sampled quarterly for 6-day duplicate diet, house dust and water, urban air and gasoline. To date there have been thirteen conceptions in immigrant subjects with 7 births, in addition to 3 conceptions in the Australian control group with two births. Blood $\mathrm{Pb}$ concentrations were generally low with a geometric mean of $3.0 \mathrm{~g} / \mathrm{dl}$ and range from 1.9 to $20 \mathrm{~g} / \mathrm{dl}$. Increases in blood $\mathrm{Pb}$ concentration of $\sim 20 \%$ during pregnancy were detectable even in these subjects with low blood $\mathrm{Pb}$ levels. Skeletal contribution to blood $\mathrm{Pb}$, based on isotopic measurements, exhibited a mean increase (and standard deviation) of $31 \pm 19 \%$ with a range from 9 to $65 \%$. Earlier studies using $\mathrm{Pb}$ concentrations only, have suggested that blood $\mathrm{Pb}$ levels increased only during the second half of pregnancy. This increase in blood $\mathrm{Pb}$ levels was also observed in the present study, however in two subjects, the increases in total blood $\mathrm{Pb}$ were also detected in the first two months of pregnancy. Changes in isotopic composition and blood $\mathrm{Pb}$ during gestation for Australian pregnant controls were negligible. Results of this study confirm that $\mathrm{Pb}$ is mobilized from skeletal stores at an accelerated rate during pregnancy and transferred to the fetus. These results also show that mobilization from long term stores (bone) contributes significantly to blood $\mathrm{Pb}$ levels during pregnancy.

\section{Environmental Geochemistry: A Vital Component of the U. S. Geological Survey Mineral Resources Program}

\author{
GUNDERSEN, L. C. \\ US Geological Survey, MS 913 National Center, Reston VA, \\ 20192, USA
}

In the last ten years, environmental geochemistry has become an increasingly important component of the U.S. Geological Survey Mineral Resources Program (MRP). The MRP has undergone extensive changes recently as the result of many external and internal factors including: a National Research Council Review, downsizing of mineral resource staff, the addition of the former U.S. Bureau of Mines minerals information and analysis functions, and reorganization within the agency itself. Throughout those changes to the MRP, an important point remained constant: earth science information and research is needed to understand the environmental implications of mineral resources throughout their life cycle: origin, weathering, extraction, production, use, re-use, and disposal. This need is rapidly growing in importance for government land management and regulatory agencies, academic institutions, the environmental consulting industry, and the mining and mineral industry. The zoncepts of sustainability, resource stewardship, and industrial ecology have become more defined (and accepted) as the realization that our land, water, and biota have real limitations due to our planet's ever increasing population growth and resource use. It is a grand challenge to all of us in the business of natural resources to look into the future, partner with each other, and take the scientific and technical lead in creating more innovative and efficient methods for conducting environmental assessments, exploration, mining, production, mitigation, remediation, and waste disposal, and for educating the geoscientists of the future.

\section{Distribution of Metals and Effects on Aquatic Biota in the Upper Stillwater River Basin, Montana}

\section{GURRIERI, J.T.}

Montana Department of Environmental Quality, P.O. Box 200901, Helena, MT 59620, USA

Acidic and non-acidic discharges from mineralized zones in the upper Stillwater River basin have resulted in elevated metals concentrations in water and sediments. The longitudinal distribution of metals and toxic effects on benthic organisms and periphyton were investigated by analyzing bed sediments, biological communities, and by conducting synoptic water quality sampling during August 1994.

Several methodologies were employed to assess the downstream attenuation of metals and the aquatic health of the river including: (1) longitudinal water quality trend evaluation, (2) congruent element analysis, (3) sediment dispersion modeling, (4) sequential extractions on sediments, and (5) macroinvertebrate and periphyton community structure analysis.

Mixing of acidic McLaren Mine drainage with alkaline waters of Daisy Creek and the Stillwater River causes rapid downstream precipitation and sedimentation of dissolved metals. Congruent element analysis indicates that longitudinal dispersion of dissolved metals is controlled by chemical removal mechanisms immediately below the confluence of Daisy Creek and by physical dilution with clean tributary inflows further downstream. The distribution pattern of metals in sediments reflects the location, degree, and type of mineralization in the basin. Sediments derived from the Stillwater Complex are enriched in $\mathrm{Cr}$ and $\mathrm{Ni}$ while sediments derived from Tertiary intrusive deposits are enriched in $\mathrm{Cd}, \mathrm{Mn}, \mathrm{Pb}$, and $\mathrm{Zn}$. The modeled pre-mining distribution of sediment bound metals in the Stillwater River suggests that metal enrichment from natural and anthropogenic acidic drainage in the McLaren Mine area extends at least $45 \mathrm{~km}$ down stream.

Macroinvertebrate and periphyton community structure exhibits a predictable response to heavy metal pollution. Biological integrity is severely impaired below Daisy Creek but improves dramatically downstream with the influx of clean water and sediment from tributaries. Slight impairment was detected in the lower reaches of the river presumably due to persistent elevated $\mathrm{Cu}$ concentrations in sediments. 


\section{Biogeochemistry of Acid Drainage from Coal Mining Operations in the Witbank}

\section{Area}

\author{
HÄLBICH, Torsten, WILLIS, James P., FEY, Martin V., and \\ JAMIESON, Heather \\ Dept. of Geological Sciences, University of Cape Town, \\ Rondebosch, 7700, South Africa
}

Disused underground collieries decant acid mine drainage (AMD) (pH 2.6-2.9, TDS 1,750-3,070 $\mathrm{mg} \mathrm{L}^{-1}$ ) in large volumes into the Blesbokspruit catchment west of Witbank, South Africa. Sediment, water, secondary mineral precipitate and algae samples were used to characterize the mobility of metals in the AMD and the extent of their immobilization, both in secondary $\mathrm{Al}$ and $\mathrm{Fe}$ precipitates and in a natural wetland downstream from the pollution source. Precipitates consisted primarily of jarosite with minor amounts of goethite, lepidocrocite, ferrihydrite, gypsum and possibly schwertmannite. Ferrihydrite precipitated on algae was the major component of only one sample. Speciation modeling of the Blesbokspruit waters generally indicated supersaturation with respect to jarosite, goethite and quartz, equilibrium with jurbanite, alunite and gypsum, and undersaturation with respect to ferrihydrite and kaolinite. Acidity of the water samples correlated strongly $\left(\mathrm{r}^{2}=0.94\right)$ with Al concentration. A receiving wetland downstream acts as a sink for a number of metals, including $\mathrm{Fe}, \mathrm{Mn}, \mathrm{Zn}, \mathrm{Ni}, \mathrm{Pb}, \mathrm{U}, \mathrm{Cu}$ and $\mathrm{Co}$, but residual $\mathrm{Pb}\left(1.3 \mathrm{mg} \mathrm{L}^{-1}\right), \mathrm{Al}\left(40 \mathrm{mg} \mathrm{L}^{-1}\right), \mathrm{Fe}(1.6 \mathrm{mg}$ $\left.\mathrm{L}^{-1}\right)$ and $\mathrm{Mn}\left(6.5 \mathrm{mg} \mathrm{L}^{-1}\right)$ concentrations persist in the water downstream of the wetland. Abundant algal growth appeared as mats at AMD outwelling points, in the stream bed, and on fringes of AMD retention ponds. Mougeotia and Microspora sp. were identified from the AMD outwelling point. Both contained Fe, while the dried Mougeotia tissue contained $800 \mathrm{mg} \mathrm{kg}^{-1} \mathrm{~V}$ and Microspora contained $230 \mathrm{mg}$ $\mathrm{kg}^{-1} \mathrm{Zn}$ and $800 \mathrm{mg} \mathrm{kg}^{-1} \mathrm{Mn}$.

\section{Preservation of Arsenic Species in Natural Waters}

HALL, G.E.M., GAUTHIER, G. and PELCHAT, J.C. Geological Survey of Canada, 601 Booth St., Ottawa, ON, Canada KIA OE8

The coupling of high performance liquid chromatography (HPLC) with the sensitive technique of inductively coupled plasma mass spectrometry (ICP-MS) allows for the determination of As species in waters, such as inorganic As, monomethylarsonic acid and dimethylarsinic acid (Thomas and Sniatecki, 1995). While the recent literature demonstrates the evaluation of this instrumentation for As, providing expected figures of merit such as detection limit, accuracy and precision, there is an absence of information on methods to preserve the distribution of As species during the period between collection and analysis. Preservation is of particular concern in work carried out by the Geological
Survey of Canada (GSC) as sample sites of interest are often in remote locations (in the Arctic regions) and shipping under refrigeration can be extremely awkward.

At the GSC, chromatographic separations of $\mathrm{As}$ (III) and As(V) were performed using the Cetac microcolumn, ANX 1606-As, a proprietary anion exchange resin. Initial testing of the system with spiked amounts of sodium arsenite and arsenate revealed an unexpected phenomenon. Distilled deionized water, at room temperature, spiked with $\mathrm{As}(\mathrm{V})$ (at 0.5 and $5 \mu \mathrm{g} \mathrm{L}^{-1}$ ) alone or mixed with As(III) showed that reduction to As(III) was occurring within hours. It was confirmed that this apparent conversion was not due to preferential precipitation or adsorption to container walls of As $(V)$. The reaction was further verified by independent analyses using hydride generation quartz tube atomic absorption spectrometry at a $\mathrm{pH}$ of 5 (only $\mathrm{As}$ (III) forms the hydride) and in $1 \mathrm{M} \mathrm{HCl}$ after reduction with $\mathrm{KI}$ (total inorganic As). Conversion of As(V) to As(III) was also evident using Ottawa River as the matrix instead of deionized water. No correlation was found with change in dissolved oxygen, organic $\mathrm{C}$ or $\mathrm{pH}$. The cause of this reaction remains to be identified but it negates the use of spiking as a test for preservation of As species.

A natural water sufficiently concentrated in As (total As of $21 \mu \mathrm{g} \mathrm{L}^{-1}$ ) was located near Ottawa for the study. A large sample was taken, filtered on-site at $0.45 \mu \mathrm{m}$, and treated various ways. Results, discussed in this paper, show that storage in the cold remains the method of choice to preserve the distribution of As(III), As(V) and organic As. Although addition of $\mathrm{HNO}_{3}$ or $\mathrm{HCl}$, to a final concentration of $0.1 \%$, preserves the As distribution from day 1 to day 30 without refrigeration, it causes an initial increase in As(III) and to a lesser extent, As(V), at the expense of organically bound As.

Thomas, P. and Sniatecki: 1995, J. Anal. At. Spectrom. 10, 615-618 (and references therein).

\section{Compatibility of Data Derived from Different Selective Extraction Schemes}

HALL, G.E.M.

Geological Survey of Canada, 601 Booth St., Ottawa, ON, Canada K1A $0 E 8$

Selective extraction schemes, where operationally defined phases are dissolved using a sequence of suitable chemical reagents, are employed in the analysis of soils and sediments to provide information as to the binding sites of elements (metals and non-metals). This knowledge is used, for example, in environmental geochemistry studies to predict the bioavailability of an element and to interpret source and pathways of deposition (e.g. clastic vs. hydromorphic transport). The scheme originally used by Tessier (Tessier et al., 1979) has been widely applied to study the partitioning of metals with depth in lake sediment cores and, together with pore water data, to estimate the degree of diagenesis and historical input. The use of sequential extraction has also been prevalent in the field of exploration geochemistry, 
with particular focus recently on the specific dissolution of the so-called 'scavenger' phases: the humic and fulvic component and amorphous $\mathrm{Fe}$ and $\mathrm{Mn}$ oxyhydroxides (Hall and others, 1996a, b). Elements migrate from depth by a variety of mechanisms (as gaseous molecules) and are fixed by these "scavenging" phases at the surface; hence, the desire to map the distribution of the labile species rather than the "total" element signature. A patented leach solution (US Patent 5491078), known as the "enzyme" leach comprising water, glucose and glucose oxidase, is used by a major commercial laboratory to specifically dissolve elements bound in the amorphous Mn oxide phase (Clark et al., 1990). An enormous database is now being established, within the exploration community worldwide, comprising metal and non-metal concentrations held in these various labile forms in sediments (stream and lake) and soils (A, B and C horizons). Thus, it would seem important that data derived for exploration purposes be compatible with those obtained by implementation of protocols (such as Tessier's) used in the sister discipline of environmental geochemistry. It also appears logical that some consensus be achieved on the selection of reference materials used to examine precision and, to a certain extent, accuracy.

This paper compares results obtained by the GSC sequential extraction scheme with those recently published by $\mathrm{Li}$ and others (1995a, b) using Tessier's method on the soil standard reference materials NIST 2709-2711 and CCRMP S0 1-4. These samples are being promoted as particularly suitable for quality control in selective extracions, whether the medium under investigation be soils or sediments. Most of the protocols for selective dissolution of organic components and $\mathrm{Fe} / \mathrm{Mn}$ oxyhydroxides in sediments have been established in the field of soil science. The second part of the paper compares the efficacy of extraction of $\mathrm{Hg}$ bound in sediments in humic and fulvic complexes using two popular leach solutions: $0.1 \mathrm{M} \mathrm{Na}_{4} \mathrm{P}_{2} \mathrm{O}_{7}$ and 0.5 $\mathrm{M} \mathrm{NaOH}$. While the pyrophosphate leach is being adopted widely in exploration geochemistry Hall et al., 1996b), the sodium hydroxide reagent remains that suggested by the International Humic Substances Society and is prominent in environmental studies in sediment analysis.

While some results by different leach schemes, designated as extracting the same phases, agree well (e.g. those for $\mathrm{Ca}$ and $\mathrm{Mn}$ in these soils), others do not (e.g. P). Application of the $0.1 \mathrm{M} \mathrm{Na}_{4} \mathrm{P}_{2} \mathrm{O}_{7}$ and $0.5 \mathrm{M} \mathrm{NaOH}$ leaches to lake sediments shows that these two reagents dissolve different groups of organic substances and that the efficiency of the $\mathrm{NaOH}$ leach is highly dependent on operating conditions (e.g. sample weight and contact time). The results presented in this paper suggest that more research is needed into the exact nature of phases purportedly extracted by selective leaches and into associated artifacts of extraction such as readsorption phenomena.

Clark, JR., Meier, A.L., and Riddle, G: 1990, Gold '90, Society of Mining ingineers, $189-207$.

Hall. G.E.M., Vaive, J.E., Beer, R., and Hoashi, M.: 1996a, J. Geochem. Explor. 56, 59-78.

Hall, G.E.M., Vaive, J.E., and MacLaurin, A.I.: I996b, J. Geochem.

Explor. 56, 23-36.
Li, X., Coles, B., Ramsey, M.H., and Thornton, I.: 1995a, Chem. Geol., 124, 109-123.

Li, X., Coles, B., Ramsey, M.H., and Thornton, I.: 1995b, Analyst, I20, I4I5-1419.

Tessier, A., Campbell, P.G.C., and Bisson, M.: 1979, Anal. Chem. 5I, 844-850.

\section{Denitrification of Nitrate-Rich Ground Water Entering Verlorenvlei Lake on the West Coast of South Africa}

\author{
HARCK, Terry, WILLIS, James P., and FEY, Martin V. \\ Dept. of Geological Sciences, University of Cape Town, \\ Rondebosch, 7700, South Africa
}

The Verlorenvlei coastal lake is situated on the southwest coast of South Africa. The area around the lake is intensively farmed (potatoes) and fertilizer-derived nitrate is suspected to contaminate the ground water.

Hydrogeological studies have concluded that ground water flows towards the lake. The nitrate concentration of the ground water is significantly higher than that of the lake. We hypothesized that the decrease in nitrate concentration between ground and lake water is due to microbial denitrification in the organic matter-rich sediments lining the lake. Two samples of sediment from different locations in the lake were homogenized under nitrogen to maintain reducing conditions, and the sediments were apportioned into jars for incubation. The sediment sub-samples were amended with $\mathrm{NaNO}_{3}$ to give as much as $100 \mathrm{mg} \mathrm{L}^{-1} \mathrm{~N}$ in solution, with and without the addition of glucose $\left(40 \mathrm{mg} \mathrm{L}^{-1}\right)$. After 10 days the concentration of $\mathrm{NO}_{3}$ had dropped to the levels present in the original sediment samples, irrespective of glucose addition, suggesting that natural organic matter in the sediments is sufficiently abundant $(10 \% \mathrm{C})$ to sustain bacterial denitrification. Recharge of the lake by nitrogenous ground water is therefore not necessarily a threat to water quality in the lake.

\section{Acid Buffering Capacity and Metals Mobility in Acid-Impacted Agricultural Soils, San Luis Valley, Colorado}

\section{HARRISON, Wendy J., WENDLANDT, R. F., JECHA- ERNSTBERGER, J., SIMON, J. I., and CHASTAIN, E. A. Department of Geology and Geological Engineering, Colorado School of Mines, Golden CO 80401, USA}

Mining activities at the Summitville site, in combination with natural weathering processes, have resulted in water quality degradation in the Alamosa River watershed. Acidic, metal-rich waters flow from Iron Creek, Bitter Creek, and Wightman Fork into the upper Alamosa River and from there into the Terrace Reservoir. Dissolved Cu, Mn, and $\mathrm{Zn}$ have been shown to pass through the Terrace Reservoir, where the $\mathrm{pH}$ is typically 4-5, and be deposited on agricultural soils in the San Luis Valley through irrigation practices. 
A variety of potential and real contamination impacts to wildlife, agriculture, and public health result from acid water in the Alamosa watershed.

The current study has been initiated to evaluate how historic irrigation has modified the acid buffering capacity and metal loading in San Luis Valley soils and to develop predictive tools for the stability and potential contamination of the soils under future, continued irrigation. Using a combination of field studies, laboratory experiments, sequential chemical extractions, and chemical modeling techniques, we are investigating: (1) existing changes in soil quality related to differences in irrigation management; (2) total acid loads that can be applied to the soil before soil quality is destroyed (loss of acid buffering capacity); (3) metals associations with individual soil components, and (4) irrigation conditions that will promote metals release from soils (metals mobility).

Results from long term batch tests, involving a minimum of 40 weekly cycles of soil-acid reaction, show that buffer capacity in the Greypoint Series soils is provided by a few percent of carbonate minerals and a high clay mineral content which is dominated by a mixed layer illite/smectite ( $50 \% \mathrm{I}, \mathrm{R}=0$ ). The acid irrigation water is initially buffered to about $\mathrm{pH} 5.5$ by a combination of $\mathrm{H}^{+}$exchange, predominantly for $\mathrm{Ca}^{2+}$ and $\mathrm{Mg}^{2+}$ in the smectite interlayer sites, and carbonate dissolution reactions. Prolonged application of highly acidic water $(\mathrm{pH} 2)$ under experimental conditions eventually exhausts the clay-dominated buffer capacity and subsequent reactions involve mineral dissolution. This condition has not yet been reached in the agricultural soils. Preliminary analysis of sequential chemical extractions reveals the association of $\mathrm{Zn}$ with carbonates and $\mathrm{V}, \mathrm{Pb}, \mathrm{Cu}$, and Co with colloidal iron and manganese oxides. Metals release from various mineralogical associations follows predictable patterns based predominantly on solution $\mathrm{pH}$. Overall, the soils are metals-rich but lie within national baseline levels. Predictive models for acid buffering capacity and metals mobility developed from the laboratory data will allow improved irrigation and soil management practices to be followed.

\section{Leaching of Contaminants from an Aggregate}

\section{HAVIS, Robert N.}

Shepherd Miller Inc. 3801 Automation Way, Suite 100, Fort Collins, CO 80525, USA

The rate of contaminant leaching from an aggregate is an important process in nonpoint-source pollution from natural geologic formations as well as from industrial and developed land. A model was developed to estimate the long-term leaching rate of contaminants from an arbitrary particle size distribution. The method employs the transformation of sieve analysis data to a particle radii frequency distribution. The leaching rate of the aggregate can then be estimated by integrating the leaching rate of each particle size based on the particle specific area. The method considers adsorption reactions, particle surface weathering, and diffusion within the lithic material. The temporal dependency is incorporated into the model through this diffusion rate process and, the exhaustion of the chemical mass in the smallest particle sizes in the aggregate.

The leaching model has application to many environmental pollution problems from geologic fracture systems to aggregate waste products from the mining industry. The model was recently used to calculate the chemical source function for a hydrologic transport model which was used to predict the long-term, nonpoint-source runoff of As from roadway material derived from smelter slag. Calibration of the model to field data was used to parameterize the lithic diffusion and weathering model. The importance of the consumption of the chemical mass of the smallest particles was demonstrated by the result that the As concentrations in runoff were reduced by approximately $80 \%$ when the chemical mass became leached from the particle sizes less than $2 \mathrm{~mm}$.

\section{Natural Arsenic In Triassic Sediments As Source Of Drinking Water Contamination In Bavaria, Germany}

\author{
HEINRICHS, Gerold, UDLUFT, Peter \\ GSF-Nat. Research Center, Inst. of Hydrology, Munich; Inst. of \\ Geology, Univ. of Würzburg; Germany
}

In Bavaria, Germany, ground water with natural As concentrations from the Keuper sedimentary formation is used for drinking water. Detailed sampling of these As ground waters shows elevated concentrations in certain geographic areas apparently related to the lithofacies of the aquifers. Almost $40 \%$ (160 wells) of deep water wells (40-200 m depth) in this area shows elevated As concentrations over 10 $\mathrm{mg} \mathrm{L}^{-1}$ to as much as $150 \mathrm{mg} \mathrm{L}^{-1}$. Using water-chemistry data in combination with geochemical investigations of drill cuttings from five wells, increased sedimentary As in certain layers of Keuper were found, and are suspected to be responsible for the increased As concentrations of the ground water. The As containing rocks are compact sediments of terrestrial to fluvial-marine depositional environments in the border facies of the Frankonian Keuper. Source area of the sediments is the crystalline continental basement of the Bohemian mass in the southeast of the research area. Elevated As concentrations in sediments and ground waters are lacking in corresponding marine sediments of the Frankonian Keuper basin facies. Reasons for increased As concentrations are regionally defined. In the south and southeast of the investigation area As occurs within minor sulfide minerals in the clayey-silty layers between the Keuper and predominantly at the top. Oxygen enriched ground water from near surface aquifers may intensify the solution of sulfides by oxidation. Local occurrence of Ashydroxide compounds of higher mobility within the coarsegrained aquifer are the most likely reason for increased As in the western part of investigation area. 


\section{Impact of the $\mathrm{Pb}-\mathrm{Zn}$ Industry on the Contamination of the Przemsza River, Upper Silesia, Poland}

HELIOS RYBICKA, E., STRZEBONSKA, M., BUDEK, L. University of Mining and Metallurgy, Al. Mickiewicza 30, 30-59 Krakow, Poland

Processing methods used for $\mathrm{Zn}-\mathrm{Pb}$ ores have caused a contamination by heavy metals of the local surface and ground-water systems. Transported as suspended matter and fine grained particles, they have been deposited in bottom sediments of the Przemsza and the upper Vistula Rivers. The distribution of heavy metals in the contaminated sediments of the Przemsza River catchment area was studied. Since the oxidizing/reducing state of the sediments varies (Eh to as much as $-330 \mathrm{mV}$ ), the speciations of heavy metals have been studied under both oxic and anoxic conditions. The total content of heavy metals $\left(\mathrm{mg} \mathrm{kg}^{-1}\right)$ is very high: up to 39,700 of $\mathrm{Zn}, 20,800$ of $\mathrm{Pb}, 254$ of $\mathrm{Cd}, 405$ of As and 564 of $\mathrm{Cu}$. A 6-step sequential extraction method revealed a significant differences of the $\mathrm{Pb}, \mathrm{Zn}, \mathrm{Cu}, \mathrm{Cd}$ and As values found at reducing conditions if compared with oxidizing ones. Generally, the chemical forms of metal under anoxic conditions are more stable; 44-96 \% of $\mathrm{Zn}, 89$ $95 \%$ of $\mathrm{Pb}, 92-99 \%$ of $\mathrm{Cd}$, ca. $100 \%$ of $\mathrm{Cu}$ and $75 \%$ of As were found in the sulfidic/organic and residual fractions. An oxidation process of examined sediments moved the speciations of all metals except As towards the more mobile .orms. Up to $40 \%$ of $\mathrm{Cd}, 80 \%$ of $\mathrm{Zn}$ and $70 \%$ of $\mathrm{Pb}$ are associated with $\mathrm{Mn}-\mathrm{Fe}$-oxyhydroxides and carbonates. Arsenic speciations are influenced to a lesser extent by oxidizing processes.

\section{Direct Methods Used for Identification of Heavy Metal Forms}

\section{HELIOS RYBICKA, E. \\ University of Mining and Metallurgy, Al. Mickiewicza 30, 30-59 Krakow, Poland}

The chemical and mineralogical forms of heavy metals in different types of environmental material; soils, sediments and wastes from the $\mathrm{Cu}$ and $\mathrm{Zn}-\mathrm{Pb}$-smelting areas, and wastes and stream sediments from a surrounding of a chemical plant have been examined by direct methods: $\mathrm{XRD}$ and SEM/EDX. The obtained results were reconciled with those received from an indirect, sequential extraction procedure.

SEM/EDX and XRD analysis of soils, sediments and wastes from the $\mathrm{Cu}$ and $\mathrm{Zn}$ - $\mathrm{Pb}$-smelting areas indicate that the $\mathrm{Cu}, \mathrm{Zn}$ and $\mathrm{Pb}$ are mainly associated with sulfides: . $\mathrm{uFeS}_{2}, \mathrm{CuS}, \mathrm{PbS}, \mathrm{ZnS}$ and sulfates: $\mathrm{PbSO}_{4}$, devilline $\mathrm{u}_{4} \mathrm{Ca}\left(\mathrm{SO}_{4}\right)_{2}(\mathrm{OH})_{6} \cdot 3 \mathrm{H}_{2} \mathrm{O}$. However, the sequential extraction suggests that a high proportion of $\mathrm{Cu}, \mathrm{Zn}$ and $\mathrm{Pb}$ (up to $70 \%$ ) could be mobilized from the exchangeable and carbonatic fractions of selected solids.
The sequential extraction method suggests that $\mathrm{Cr}$ in the wastes from a chemical plant was found as an exchangeable form and about $50 \%$ of the $\mathrm{Cr}$ was associated with the reducible or residual fractions. The major $\mathrm{Cr}$-forms in the sediment determined by chemical extraction method are in compounds with Fe-oxides, and sulfides (up to 86 and $30 \%$ respectively).

SEM/EDX and XRD analysis of waste material and river sediment indicate, that the main insoluble $\mathrm{Cr}$-phase is ferroan - $(\mathrm{Mg}, \mathrm{Fe})(\mathrm{Cr}, \mathrm{Al})_{2} \mathrm{O}_{4}$. Most of the evidence obtained from $\mathrm{SEM} / \mathrm{EDX}$ technique suggests that $\mathrm{Cu}, \mathrm{Pb}$ and $\mathrm{Zn}$ in the environmental samples from $\mathrm{Zn}-\mathrm{Pb}$ and $\mathrm{Cu}$ smelting areas occur in the sulfide form, but such sulfides should be relatively inert to the mild extractants used in the chemical procedure. One possible explanation is that oxidation reactions have converted much of the metal sulfides to soluble hydrous sulfates, such as devilline.

\section{Organometal(oid) Species in Geochemical Exploration: Preliminary Qualitative Results}

\author{
HIRNER, A.V., KRUPP, E., and SCHULZ, F. \\ Institute of Environmental Analytical Chemistry, University of \\ Essen (F.R.G.)
}

Organic and other metal(loid) species (e.g. hydrides) in environmental gases can be determined with high sensitivity and selectivity by low temperature gas chromatography coupled on-line with plasma mass spectrometry (LTGC/ICPMS). A standard reference solution is analyzed simultaneously for calibration of the results as well as for monitoring the excitation conditions in the plasma.

Several compounds of eleven elements have been found in environmental gases (esp. waste and sewage gases) in concentrations of $\mathrm{ng}$ to $\mu \mathrm{g}$ per $\mathrm{m} 3$ of gas. Similar compounds could also be traced in waters and associated sediments. Prior to analysis by LTGC/ICP-MS these samples must be volatilized by derivation leading to hydrides ( $\mathrm{HG}=$ hydride generation). Advantages and problems associated with these techniques are critically discussed: although gas analysis exhibits extreme low detection limits, the hydride technique is characterized by relatively high reagent blanks and possible transformations between organic species governed by their stabilities in aqueous media (dependent on $\mathrm{pH}$ and other parameters).

LTGC/ICP-MS (soil gas) and HG-LTGC/ICP-MS (soil) were applied in field screening tests at two ore deposits in Germany. In some of the soil gas and soil samples investigated organic compounds of several metal(loid)s (e.g., As, $\mathrm{Hg}$ ) could clearly be identified. The geochemical implications of these results are critically discussed. In particular, emission yields of metal(loid)organic species in ore deposit gases are significantly lower when compared to waste and sewage gases, probably because geogenic materials exhibit much less metal(loid)s in bioavailable forms than do anthropogenic wastes. 


\section{Testing Contaminant Mobility in Soils and Waste Materials}

\section{HIRNER, A.V., PESTKE, M., BUSCHE, U. and ECKELHOPF, A. Institute of Environmental Analytical Chemistry, University of Essen (F.R.G.)}

Contaminant mobility in soils and waste materials is usually tested by standardized elution procedures. In Germany batch experiments are run for 24 hours at a liquid/solid ratio of 10:1. While mobilities of metal(loid)s and hydrophilic organic compounds (phenols) can adequately be tested by automatic titration stands working at constant $\mathrm{pH}$ values representative of relevant environmental scenarios $(\mathrm{pH} 4$ for simulating acid waste waters or $\mathrm{pH} 10$ for ash deposits), this doesn't hold true for hydrophobic organic chemicals like PAH, PCB or PCDD/F. For these chemicals natural solubilizing agents have to be taken into account. Because the solubilities of PAH and PCB decrease with increasing molecular weight, this solubilization effect becomes more pronounced with high molecular weight compounds.

The results of relevant experiments using natural as well as synthetic eluting solutions will be presented, demonstrating that sodium dodecyl sulfate (SDS) is suitable as a reference solutizer. The solubilizing potential of SDS is comparable to the most potential natural solutizers like phospholipids or humic acids for each contaminant, and thus represents a worst case scenario. In a similar way, contrary to waters rich in dissolved organic carbon (DOC) like sewage or compost waters, highly diluted waters like rain water show only a small solubilizing potential for hydrophobic contaminants. Within this scenario compost waters were found to represent the worst case; again comparable amounts could be eluted by a SDS solution.

\section{Ecological Changes in Florida Bay - Can We Tell When It Happened?}

\author{
HOLMES, C. ${ }^{\prime}$, ROBBINS, $\mathrm{J}^{2}$, BOTHNER, M. ${ }^{3}$, HALLEY, R.+, \\ SHINN, G. ${ }^{+}$, RUDNICK, D. ${ }^{5}$, TEN-BRINK, M. ${ }^{3}$, MAROT, $M .^{\prime}$, \\ MOREHEAD, N. ${ }^{2}$, GILL, $P^{3}$, CASSO, M. ${ }^{3}$, GRANEY, ${ }^{6}{ }^{6}$, \\ KEELER, $G^{6}{ }^{6}$ and RENDIGS, $R^{3}$ \\ 'U.S. Geological Survey, P.O. Box 25046, Denver, CO 80225, USA \\ ${ }^{2}$ G.L.E.R.L, NOAA, Ann Arbor, MI \\ ${ }^{3}$ U.S. Geological Survey, Woods Hole, Ma. \\ ${ }^{+}$U.S. Geological Survey, St. Petersburg, FL \\ ${ }^{5}$ S.F.W.M.D., West Palm Beach, Fl \\ ${ }^{6}$ School of Public Health, U. Michigan, Ann Arbor, MI
}

Long-term ecological changes in Florida Bay are dominated by sea-level rise and transgression and have been well documented using ${ }^{14} \mathrm{C}$ chronologies with a resolution of several hundred years. Any serious attempt to reconstruct short-term changes, with a focus on ecosystem restoration, requires a reliable high-resolution chronology. In areas such as Florida Bay, which do not possess special features (varves), short-lived natural and recently dispersed radionuclides may be useful. To test the usefulness of these nuclides, 20 cores, up to 2 meters long, were collected. The cores were taken in grassy and non-grassy areas and represent most environments throughout Florida Bay.

$\mathrm{X}$-radiographs of the cores revealed that many cores possessed layers; those in the grassy areas were coarsely layered whereas those from the non-grassy or "barren" areas were finely laminated. The fine layering in the cores suggests that bioturbation is not a problem for radiometric dating. ${ }^{210} \mathrm{~Pb}$ activities, extracted from the $<62 \mu \mathrm{m}$ fraction, were highest $\left(\sim 3-5 \mathrm{dpm} \mathrm{g}^{-1}\right)$ at the surface and decrease to background within 50 to $150 \mathrm{~cm}$. Acceptable determination of sediment accumulation rates, under general conditions of an unfavorable signal to noise ratio along with down core variability of ${ }^{226} \mathrm{Ra}$ and ${ }^{210} \mathrm{~Pb}$, necessitated measurement of both nuclides in all sections of the core.

In the presently best characterized cores from "barren" areas on Bob Allen Key and Russell Bank, down core ${ }^{226} \mathrm{Ra}$ activity correlates with the extracted ${ }^{210} \mathrm{~Pb}$ with the result that the "excess" ${ }^{210} \mathrm{~Pb}$ are simple exponential profiles. Using this profile, the rate of sediment accumulation is estimated to be $0.84 \pm 0.05 \mathrm{~g} \mathrm{~cm}^{-2} \mathrm{a}^{-1}$. Profiles of total lead versus dates overlap almost perfectly with a record of total lead measured in annual bands of the coral (Monastera annularis) from the same region. The agreement between coral and sediment confirms that some sites in the bay hold a valid chronological record and suggests the assumptions of even rudimentary dating models may be applicable to this complex system.

\section{Quantification of Environmental Exposure Vectors by Geochemical Methods}

\author{
HOOGEWERFF, Jurian' and STAESSEN, Jan ${ }^{2}$ \\ 'Deptartment of Anal. Geochem., Fed. Research Centre \\ ARSENAL, Faradaygasse 3, A-1031 Vienna, Austria \\ ${ }^{2}$ Department of Pathophysiology, University Leuven, Herestraat \\ 30, B3000 Leuven, Belgium
}

Many studies have documented cases of elevated levels of trace elements in human blood and other tissues as result of environmental exposure. Although the source of the exposure is often located without great difficulty, it has been notoriously troublesome to qualify the exact routes of exposure.

In a attempt to both qualify and quantify the exposure vectors around a zinc smelter in non-industrialized area in the Belgian Kempen we analyzed the emissions of the smelter, the different possible pathways: water, dust (outdoor and indoor), garden soil, vegetables, and blood of more 500 inhabitants.

Our results at present show a correlation between the distance of the individuals from the pollution source and the concentration of trace elements (Cd) in the blood. Blood $\mathrm{Pb}$ isotope results show a correlation between lead concentration and the origin of the lead. Low concentrations are close to the local geogenic background and the high concentrations are close to the pollution source values indicating mixing of the intake from both sources.

Detailed analysis of all the media will hopefully shed 
light on the pathways. This paper presents the progress of our study.

\section{Archaeological Bone as Baseline for Present Day Human Exposure}

\author{
HOOGEWERFF, Jurian', KRALIK, Martin ${ }^{2}$ and BERNER, \\ Margit $^{3}$ \\ 'Dept. Anal. Geochem., Fed. Research Centre ARSENAL, \\ Faradaygasse 3, A-1031 Vienna, Austria \\ 2Dept. Environmental Geochem., Ministry of Environ., \\ Spittelauerlände 5, A-1090 Vienna, Austria \\ ${ }^{3}$ Dept. Anthropology, Natural History Museum, Burgring 7, A- \\ 1014 Vienna Austria
}

In cases of human exposure to industrial contaminant sources it is common practice to compare results (for example from blood or hair) from the exposed group to results from unexposed groups which live under similar conditions. As the background level of the non-exposed group (in the industrialized world) is also likely to be elevated it seems logical to use archaeological material from the area under study, dated before the industrialization. As archaeological blood is not available and hair is prone to contamination if it is preserved, we use bone material. Bone material is stable for centuries under certain conditions. Bone material also provides an indication of average longterm exposure as the half-life of bone is around 7 years. ' $n$ a study to test the suitability of archaeological bone material for reference we have analyzed bone material from individuals, from the $18^{\text {th }}$ century, with 5 original habitats located on different geological backgrounds. In cases of natural exposure one would expect a correlation between the composition of intake through water, dust and home-grown food. The composition of these exposition vectors will be a function of the local geochemistry.

The area encompassing North and South Tyrol was chosen for this project as there is a large compositional contrast between limestones in the Northern and Southern "Kalkalpen" and the Central Gneiss zone in the middle. In a pilot study we found good correlations between the Limestone/Gneiss contrast in $\mathrm{Sr}$ isotopic composition and in the Rare Earth Element (REE) levels. Other trace elements show significant clustering at each location indicating, compositionally, well constrained intake vectors. At present we are enlarging our database in order to enhance the resolution to smaller geological units. In our presentation we will compare the bone compositional map with modern bone from people which have been living in the neighborhood of the Brenner Highway crossing the Alps. We will also report on an archaeological/anthropological spin-off of our project as the bone compositional map also provides reference for the origin of the Iceman from Hauslabjoch 'Oetzi' whose bone we also analyzed.

\section{The Use of Holocene Floodplain Sedimentary Sequences for Geochemical Mapping in the Yorkshire Ouse River Basin, UK}

\author{
HUDSON-EDWARDS, Karen A., TAYLOR, Mark P., and \\ MACKLIN, Mark G. \\ School of Geography, University of Leeds, Leeds L52 9JT, UK
}

Overbank sedimentary profiles record both the natural and anthropogenic geochemical evolution of floodplains. These can be used for geochemical mapping and contaminant assessment, provided that the fluvial evolution and human history are well understood, and the sediment can be accurately dated.

Holocene and historic environmental change in the Yorkshire Ouse River Basin in north-east England is being studied under the UK LOIS (Land-Ocean Interaction Study) program. A variety of techniques have been utilized in order to evaluate the influence of environmental change on river basin sediment and chemical fluxes. Selected floodplain reaches have been geomorphologically mapped, surveyed, and assessed for archaeological assemblages. Bulk samples from distinct sedimentological units within drill cores taken from representative river terraces have been analyzed by $\mathrm{X}$ ray fluorescence (XRF) for $\mathrm{Al}, \mathrm{As}, \mathrm{Ba}, \mathrm{Ca}, \mathrm{Co}, \mathrm{Cr}, \mathrm{Cu}, \mathrm{Fe}$, $\mathrm{K}, \mathrm{Mg}, \mathrm{Mn}, \mathrm{Ni}, \mathrm{Pb}, \mathrm{Rb}, \mathrm{Si}, \mathrm{Sr}, \mathrm{Ti}, \mathrm{Y}, \mathrm{Zn}, \mathrm{Zr}$. Age control has been provided by ${ }^{14} \mathrm{C}$ dating of organic materials within the cores.

Overbank sediment geochemical mapping of reaches on the Swale, Ure, and Nidd rivers in the upper Yorkshire Ouse basin is used for three main purposes. Contaminant assessment is carried out by comparing sediment-borne contaminant (mainly heavy metal) contents to guideline values set out by the U.K. Inter-Departmental Committee on the Redevelopment of Contaminated Land. Volumes of contaminated sediment are calculated by multiplying thicknesses of designated contaminated units by river terrace areas. Elevated contents of sediment-borne $\mathrm{Pb}, \mathrm{Zn}$ and $\mathrm{Ba}$ in many alluvial units may be largely due to large-scale metalliferous metal mining in the upper parts of the catchments, particularly during the seventeenth to nineteenth centuries. Correlation of alluvial units is carried out by comparing 'spidergrams' of multielement data (normalized to upper crustal values) for the cores, in combination with radiocarbon dating information. The fundamental geochemical and sedimentological changes within the cores are related to Holocene and historic environmental change. This is caused by factors such as prehistoric woodland clearing and heather burning, related hillslope erosion, agricultural practices, climatically controlled variations in flood frequency, and sea-level change. 


\section{Source Attribution Of Lead Particles In Pre- And Contaminated Post-Lead Paint Abatement Interior Dusts}

HUNT', Andrew, HAWKINS ${ }^{2}$, J., GILLIGAN ${ }^{2}$, E., and BHATIA ${ }^{2}, S$. 'Department of Pathology, SUNY Health Science Center, 750 East Adams St., Syracuse NY, 13210, USA

${ }^{2}$ Department of Civil and Environmental Engineering, Syracuse University, Syracuse NY, 13214, USA

The particulate lead $(\mathrm{Pb})$ present in the settled dust in a unit in a public housing complex was characterized using a combination of scanning electron microscopy (SEM) and energy dispersive X-ray spectroscopy (EDS) to identify the source(s) of the $\mathrm{Pb}$. The unit was scheduled for $\mathrm{Pb}$ paint removal and it was hypothesized that elevated levels of $\mathrm{Pb}$ in the dust resulted from the deterioration of the $\mathrm{Pb}$-based paint on the interior surfaces. SEM/EDS analysis was chosen to identify the sources of the particulate $\mathrm{Pb}$ as the technique proceeds on a particle-by-particle basis and provides information on particle form and chemical composition. Size fractionated floor dust samples $(<40 \mu \mathrm{m}$, and $40-100$ $\mu \mathrm{m}$ ) from 4 rooms in the unit were analyzed by SEM/EDS and were found to contain a wide range of $\mathrm{Pb}$-particle types. The particles were classified on a room-by-room basis into 24 specific categories, and 8 particle types were found to have unique morphological and/or chemical characteristics. The floor-dust $\mathrm{Pb}$ loadings in all 5 rooms in the unit prior to the removal of the $\mathrm{Pb}$-paint covered building components were _ $100 \mu \mathrm{g} \mathrm{ft}^{-2}$ (Table). Immediately after the abatement, the floor-dust $\mathrm{Pb}$ loadings in all rooms were less than those before the abatement. But, a resampling of the floor dust 2 months after the abatement identified floor-dust $\mathrm{Pb}$ loadings in 2 rooms that exceeded the pre-abatement loadings.

Individual particle analysis of floor dusts samples obtained 2 months after the abatement found that in the 2 rooms with elevated $\mathrm{Pb}$ loadings the $\mathrm{Pb}$ was unlike that present in any of the pre-abatement dusts. It was subsequently found that this re-contaminating particulate $\mathrm{Pb}$ was morphologically and compositionally consistent with $\mathrm{Pb}$ scraped from the interior of one of the radiators which had been removed from the complex some time after the abatement. We concluded that water present in the radiators, which spilled during the course of their removal, was the source of the high dust $\mathrm{Pb}$ levels in these rooms. This unexpected source of recontamination may be an important source of $\mathrm{Pb}$ exposure in similar circumstances as it is usually the case that during the course of an abatement only a single post abatement dust sample is collected and this taken immediately following the abatement.

Lead loading $\left(\mu \mathrm{g} \mathrm{ft}^{-2}\right)$ in floor dust before and two months after the abatement.

\begin{tabular}{l|c|c}
\hline Unit Location & Pre-abatement & Two Months Post- Abatement \\
Living Room & 581 & 88 \\
Southeast Bedroom & 497 & 37 \\
North Bedroom & 391 & 1790 \\
Kitchen & 100 & 127 \\
Laundry & 163 & 472 \\
\hline
\end{tabular}

\section{Changes in Urban Geochemistry in Nottingham and Birmingham between 1982 and 1997}

\author{
HUTCHINSON, E.J.', FARAGO, M.E.', SIMPSON, P.R. ${ }^{2}$, ST. \\ CLAIRE GRIBBLE, K.', THORNTON, I.' \& HALL, G. ${ }^{3}$ \\ 'Environmental Geochemistry Research Group, Centre for \\ Environmental Technology, Imperial College, London SW7 2BP, \\ UK \\ ${ }^{2}$ British Geological Survey, Keyworth, Nottingham NG12 5GG, UK \\ ${ }^{3}$ Geological Survey of Canada, Ottawa ON, Canada KIA OE8
}

In recent years, there has been a large increase in the amount of traffic on the roads and the distances traveled. This, combined with reports in the media of decreasing urban air quality, has resulted in growing public concern over pollution associated with road transport.

Since 1993, all new petrol engined vehicles have been fitted with three-way catalytic converters in order to comply with EC stage I limits on emissions of carbon monoxide, hydrocarbons and nitrogen oxides $\left(\mathrm{NO}_{2}\right.$ nitrogen dioxide and NO nitric oxide). However, it is not known whether there are any negative effects associated with the use of catalytic converters. The substances used as catalysts for the reductive and oxidative reactions involved are $\mathrm{Pt}$ and $\mathrm{Pd}$. It is not known whether increasing roadside depositions of these metals will have adverse health effects.

A survey of garden soils was carried out in Birmingham in 1982 and Nottingham in 1984 with support from the Department of the Environment, and the soil samples were analyzed for $\mathrm{Pb}, \mathrm{Cu}, \mathrm{Zn}$ and $\mathrm{Cr}$ content. These samples have been reanalyzed for $\mathrm{Pb}, \mathrm{Pt}, \mathrm{Pd}$ and other heavy metal content. The soil sampling was repeated at the same locations in 1996 and 1997, and the $\mathrm{Pb}, \mathrm{Pt}$ and other heavy metal content analyzed. Road dust was also collected and analyzed for heavy metal content in the $1996 / 1997$ surveys. The results of the two surveys will be presented and compared.

\section{Contaminant Detection On Soils Using Static SIMS}

INGRAM, Jani C., GROENEWOLD, Gary S., and APPELHANS, Anthony $D$.

Idaho National Engineering Laboratory, Idaho Falls, Idaho 834I5, USA

Static secondary ion mass spectrometry (SIMS) was used for the detection of contaminants on soils. Both broad-beam and microprobe SIMS instruments have been used in these studies. The combination of these techniques has provided information concerning how much contaminant is present (semi-quantitatively) and where the contaminant adsorbs with respect to the underlying substrate. An example of a contaminant investigated is the pinacolyl methylphosphonic acid (PMPA) which is a degradation product of the nerve agent soman (or GD). Static SIMS detects PMPA by bombarding soil with high energy particles, which sputter 
the PMPA and its fragments into the gas phase. Those molecular fragments which are ionized are then mass analyzed. A lower limit of detection for PMPA on soil using an ion trap SIMS instrument with a broad-beam primary ion source was determined to be $3 \mathrm{pg} \mathrm{mm}^{-1}$ ( 0.002 monolayers). Only $3 \mathrm{mg}$ of soil and no sample preparation was required for these analyses. In order to overcome the chemical background, which can be detrimental in direct surface analysis of environmental samples, multiple stages of mass spectrometry were performed utilizing the ion trap mass analyzer. Adsorption of the PMPA on specific regions of the soil was investigated using a SIMS microprobe; these results will be discussed in this paper.

\section{Laboratory Leaching Behavior of an Arkansas River Fluvial Tailings Deposit, Leadville, Colorado}

\author{
JERZ, Jeanette K.' RANVILLE, James F. ${ }^{2}$, HARRISON, Wendy J.' \\ 'Department of Geology and Geological Engineering, Colorado \\ School of Mines, Golden CO 80401, USA \\ ${ }^{2}$ Department of Chemistry and Geochemistry, Colorado School of \\ Mines, Golden CO 80401, USA
}

Turn of the Century mining activities near Leadville, $\mathrm{CO}$ has led to the introduction of mine tailings into Arkansas River fluvial sediment. These metal-sulfide-rich deposits represent a potential source of contamination to the local ground water nd the Arkansas River. Currently the leaching behavior of these deposits is largely unknown. We have quantified the release of acidity and metals from these deposits using laboratory leaching of an intact core $(20 \mathrm{~cm}$ diameter by 90 $\mathrm{cm}$ length) collected from a site $13 \mathrm{~km}$ south of Leadville, $\mathrm{CO}$. DI water was introduced to the top of the core during leaching experiments at $2.0 \mathrm{ml} \mathrm{min}^{-1}$ for up to eight days. Conductivity, $\mathrm{pH}$, and selected metal and anion concentrations were determined on samples collected from the core base. Several months of drying prior to the first leaching experiment produced substantial sulfate-salt formation on top of the core. Salts of similar appearance are also observed in the field and are expected to affect leaching behavior. The initial leachate $\mathrm{pH}$ was 1.6 , rose rapidly to 2.1 , and was 2.3 by the completion of the experiment. Initial concentrations of metals, in $\mathrm{mg} \mathrm{kg}^{-1}$, were $\mathrm{Fe}$ total $=2,600$, $\mathrm{Al}=180, \mathrm{Zn}=9.4, \mathrm{Cu}=7.8, \mathrm{Mn}=6.0$, and $\mathrm{Pb}=1.2$. Acidity and concentrations of all metals except $\mathrm{Mn}$ exponentially decreased to plateau values between $20-50 \%$ of the initial values. For $\mathrm{Mn}$ a gradual increase occurred. This study has found that formation of efflorescent sulfate-salts during wetting-drying cycles is important to the leaching behavior of these tailings. The very low $\mathrm{pH}(<2.0)$ and very high metal leachate concentrations during the initial phase of the experiment indicate a salt-dissolution mecha-

sm that is important on a short time scale. The low $\mathrm{pH}(2$ \lrcorner$)$ and elevated metals concentrations in the plateau region indicate other reactions are important on a longer time scale.

\section{Geochemical Transport Modeling Of Mine Tailings Pore Water}

\author{
JORDAN', David L., NEWCOMER', Robert W., and \\ MACKINNON, Robert J. ${ }^{2}$ \\ 'Daniel B. Stephens and Associates, Inc., 6020 Academy NE, Suite \\ 100, Albuquerque, NM 87109, USA \\ ${ }^{2}$ Applied Physics Inc., 8100 Mountain Road NE, Suite 217, \\ Albuquerque, NM 87110, USA
}

Chino Mines Company is currently evaluating potential closure alternatives for its older tailing pond areas near Hurley, NM. One of the critical factors affecting the selection of an appropriate closure alternative is the determination of potential present and future effects of tailing seepage on underlying ground-water quality. Transport and hydrogeochemical modeling was performed to develop estimates of (1) the chemistry of water leaving the bottom of the tailing, (2) the chemistry of water attributable to tailing seepage that enters the underlying Gila Conglomerate aquifer at the base of the unsaturated zone, and (3) mass loading of dissolved constituents and temporal variations in the quality of the seepage. An additional objective of the modeling was to evaluate the acid-buffering capacity of the tailing and the underlying unsaturated Gila Conglomerate. The geochemical model considered speciation of dissolved constituents and also allowed precipitation and dissolution of solid mineral phases. The BLT-EC code was used for the simulations. BLT-EC links the ground-water transport code HYDROGEOCHEM with the well-validated equilibrium geochemical speciation code MINTEQA2 and its associated thermodynamic database. BLT-EC is unique in that it links an unsaturated flow and transport code with an equilibrium geochemical code in one package. Transport of acidic tailing pore water and dissolved metals in the tailing is generally limited by the low recharge rate $\left(2.5 \mathrm{~cm} \mathrm{a}^{-1}\right)$. Attenuation of the acidic porewater results from reactions with carbonates and mixing with porewater in unoxidized tailing and Gila Conglomerate.

\section{Characterization of Gypsum Mine Wastelands and Their Rehabilitation}

JOSHI, D.C. and SHARMA, K.D.

Central Arid Zone Research Institute, Jodhpur 342003

In the tropical desert region of Rajasthan (India) gypsum deposits are wide spread and gypsum strip mining is an important activity. The depth of gypsum may vary from few $\mathrm{cm}$ to more than $5 \mathrm{~m}$ below the surface. Most of the gypsiferous lands are used for raising irrigated crops. The gypsum-bearing lands are acquired by the state on lease basis from farmers. After extraction of gypsum the lands are backfilled and returned to the farmers. Crop growth on these backfill lands is very poor and yields are extremely low. A study was conducted to characterize the undisturbed and backfill sites for investigating the causes of low yields at backfill sites and plan strategies to harvest full potential. 
The study area is located in the northern part of Rajasthan state, India, in Bikaner, Hanumangarh and Ganganagar districts. The climate is hot arid with $200-300 \mathrm{~mm}$ rainfall per annum and high evapotranspiration. During summer in the month of May and June the maximum temperature may reach up to $49^{\circ} \mathrm{C}$ whereas in winter minimum temperatures of 1 to $2^{\circ} \mathrm{C}$ have been recorded. The terrain is vast sandy plain covered with sand dunes. The gypsiferous areas occur in interdunes which have centripetal drainage and slightly finer soil texture than the adjoining areas.

At several sites the backfill areas were studied for soil profile characterization and terrain features (Soil Survey Staff, 1951). Soil samples from different horizons were collected. These were crushed with pestle and mortar and passed through $2 \mathrm{~mm}$ sieve. Contents of coarse fragments $(>2 \mathrm{~mm})$ were recorded. The fine earth fraction $(<2 \mathrm{~mm})$ was used for determination of $\mathrm{pH}$ and electrical conductivity (1:2 soil -water suspensions) and $\mathrm{CaCO}_{3}$ (Calcimeter), organic matter (Walkley and Black's method), available phosphorus (Olsen's method) and available potassium $\left(\mathrm{NH}_{4} \mathrm{OAc}\right)$, moisture equivalent according to Jackson (1967) and Piper (1950). The available micronutrients were determined according to Lindsay and Norvell (1978). Results of different sites have been reported in this paper. The surface of backfill areas is generally uneven and at a relatively lower elevation compared to its surrounding. Clods and gypsum nodules are also strewn on the surface. Profile examination revealed that the backfill is a stratification of the noncoherent earth material varying in mechanical composition, coarser in texture than the undisturbed sites and has high proportion of gravels/nodules. The porosity and capillaries are totally disrupted.

The available water capacity is also less than the undisturbed soil. Similarly the available $\mathrm{Fe}, \mathrm{Mn}, \mathrm{Cu}$ and $\mathrm{Zn}$ content of backfill is also very low. Thus adverse physical condition of backfill for plant growth and non-availability of nutrients have reduced the productivity of the backfill lands. There is immediate need of regeneration of physical and microbial environment of root zone. This can be achieved by application of farm yard manure, green manuring and cultivation of legume crop and castor (Ricinus communis), initially for two years. Deficiency of phosphorus should be compensated by application of phosphatic fertilizer and farmyard manure.

\section{Soil Parameters as a Basis for the Assessment of Trace Metal Pollution}

\author{
KABATA-PENDIAS, Alina \\ Institute of Soil Science and Plant Cultivation, 24-100 Pulawy, \\ Poland
}

Background contents of trace metals in surface soils, which are the basic criteria for the assessment of soil pollution by metals, do not exist today, especially in Europe. The primary concentration of metals can be estimated using various methods. One of the geochemical techniques is to calculate enrichment factors, comparing the abundance of each element in a soil sample to its content in the host rock, and normalize to an element that has wide occurrence and is relatively stable in various geochemical environments. However, several soil factors and soil-forming processes are known to govern the content of trace metals, and therefore it seems reasonable to establish the background metal content for a given soil type developed under similar climatic conditions.

To evaluate the background content of trace metals in mineral soils of Poland, surface soil samples (over 800 samples from depths of $3-15 \mathrm{~cm}$ ) were collected in 19931995 from throughout the country. Total metal content (aqua regia soluble) was measured in air dried soil samples ( $<2 \mathrm{~mm}$ sieve) by AAS and ICP spectroscopy. Measurements of other soil parameters included: (a) $\mathrm{pH}$ in $1 \mathrm{~N} \mathrm{KCl}$, (b) $<0.02 \mathrm{~mm}$ granulometric fraction (CF) by modified Cassagrandes method, (c) organic matter (SOM) by Tiurin's method, (d) $\mathrm{CEC}$ in $1 \mathrm{~N} \mathrm{CH}_{3} \mathrm{COONH}_{4}$ buffered extraction, and (e) base saturation (BS) calculated as a sum of total exchange cations.

Trace metals in surface mineral soils were significantly correlated mainly with CF and SOM. CF seems to especially affect the abundance of $\mathrm{Fe}, \mathrm{Mn}, \mathrm{Cr}, \mathrm{Ni}, \mathrm{Ba}, \mathrm{La}, \mathrm{Li}$, and $\mathrm{V}$, whereas SOM is more closely correlated with $\mathrm{Cd}, \mathrm{Cu}, \mathrm{Pb}$, $\mathrm{Zn}$, and also $\mathrm{Fe}$. The background contents of trace metals were calculated based on CF content, and compared with the analytical data. The measured and calculated values were

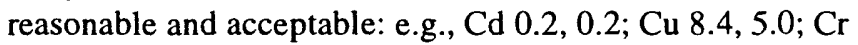
7, 9; Mn 293, 315; Ni 4.6, 5.0; Pb 13, 12; Zn 41, 40, respectively.

The determination of soil texture and CF can serve as data for the estimation of background metal contents in soils. This calculation can operate only for soils derived from similar geologic materials, and for soils developed under similar climatic conditions.

\section{Chernobyl Contamination As A New Geographical Factor In Belarus}

\author{
KADATSKAYA, Olga V. \\ Institute of Natural Resources Use and Ecology. 10 \\ Staroborisovsky trakt. Minsk, 220114. Belarus
}

As a result of the Chernobyl accident a new geochemical province was formed on the territory of Belarus and occupies $23 \%$ of its area with more than 2 million people. Landscape and experimental investigations were used to subdivide the Belarussian radiogeochemical province into four regions. They differ both in natural features and characteristics of contamination. The four regions are: (1) the central region, represented by small areas confined to the southwestern branch of the Belarussian Ridge, (2) the southwestern region, occupying the southern part of the Pripyat Polessie area, (3) the eastern region, covering mainly the Orsha-Moguilev loessial plateau and the Chechersk morainic plain on the Dnieper River left bank, and (4) the southeastern region, situated mostly within the Gomel Polessie boundaries. 
It became apparent that contaminated natural, seminatural and agricultural ecosystems were sources of human exposure because of the biological cycles of radionuclide migration and their transfer in the food chains. Many generations of people will live in these conditions. It was substantiated that the technogenic contamination of Belarus by radionuclides of Chernobyl fallout has formed a new geographical factor. The consequences of this factor in influencing the health of the population in the radiogeochemical regions are unknown in many details.

\section{Resuspension Of Radionuclides In Belarus Soils Distant From The Chernobyl Nuclear Power Plant}

KADATSKY, Valery B., KAGAN, Leonid M., and SAMSONENKO, lgor $P$.

Institute of Natural Resources Use and Ecology. 10

Staroborisovsky trakt. Minsk, 220114. Belarus

Radionuclides found in the environment after the Chernobyl accident have been involved in various migration processes. Field studies were carried out in the central radiogeochemical region (northwest of Minsk) to measure the behavior of dose rates.

Some features of the contamination pattern were revealed. One of them is the point increase of the dose rate in localities of precipitation water discharge, near roof gutters, and under tops of separately growing trees. The contamination pattern $(\mathrm{CP})$ under trees is dependent on the tree species. For deciduous trees, the main path for precipitation water drainage is from the tops along the tree trunk and the higher dose rate values are detected near the trunks. On the other hand, for coniferous trees, the higher dose rate values are observed near the soil around the periphery of the tree.

The CP of a second type is linear in character and observed along the edges of forest strips and large forests. The CP of a third type has a spot characteristic. The location of these spots depends on the primary nuclide fallout, precipitation type, relief features, occurrence of forest and bog, etc. The understanding of these regions is still in progress.

\section{Heavy Metals in Humus and Organogenous Layers with Different Human Activities}

KADATSKY, Valery $B$.

Institute of Natural Resources Use and Ecology. 10

Staroborisovsky trakt. Minsk, 220114. Belarus

The object of our investigations were humus layers of modern soils of connected elementary landscapes affected by anthropogenic impact and different sedimentary organogenous strata (involving modern lake deposits). The evolution of the middle and upper Quaternary and Holocene geosystems was analyzed with a synchronous space correlation of the concentrations of technogenic trace elements.

The associations of heavy metals $(\mathrm{Ti}, \mathrm{V}, \mathrm{Cr}, \mathrm{Mn}, \mathrm{Co}, \mathrm{Ni}, \mathrm{Cu}$, $\mathrm{Pb})$ are considered.

Trace element contents of ancient Quaternary peats, Holocene peats and modern peats are not very different. Time of beginning of technogenic chemical elements in lake deposits (sapropel) due to anthropogenic activity has been established.

The forms of trace element occurrence in humus horizons of natural, agricultural and urban soils are significantly different. The ratio of relatively mobile forms to firmly bound forms is higher for the urban soils compared to the natural ones and depends on levels of anthropogenic impact. To estimate these trace element levels it is necessary to calculate the above ratio, as the total contents of heavy metals are not informative.

\section{Chernobyl Nuclides in Soils and Gamma- Dose Rate in Air Of Belarus}

KAGAN, Leonid M., and KADATSKY, Valery B. Institute of Natural Resources Use and Ecology 10 Staroborisovsky trakt. Minsk, 220114. Belarus

Experimental studies were carried out at a set of reference sites which differ in geographical location, relief type, as well as the soil type and vegetation cover. In each reference site, the above-ground gamma-radiation exposure rate was measured several times a year. Simultaneously, soil samples were taken to obtain the vertical profile of radionuclides. Results of dose-rate monitoring, which demonstrate some regular features, are discussed. An attendant problem of the dose-rate changes in air and the vertical distribution of gamma-emitting radionuclides in soil is considered. The model of the radiation situation assessment is elaborated with landscape and geochemical peculiarities of the contaminated territory. The model calculates in quasi-real time the dose rate levels and gradients, exposure dose commitments, and inventories and vertical distribution of the main radionuclides, including ${ }^{90} \mathrm{Sr}$.

\section{Environmental Monitoring of Geochemical Changes in Ash-Dumps and Silage-Heaps}

\author{
KAPINUS, Evgeny I., SPILNY, Sergey A., STCHOGOLEV, \\ Aleksandr K., and KORENCHUK, Ludmila V. \\ Research Center Sonar of the Ukrainian Academy of Sciences, \\ Prospekt Pobedy, 52/2, Kiev 252057, Ukraine
}

This abstract deals with an exploration of the environmental problems of the biggest dumps of coal ash in the Ukraine and with analysis of the potential for non-ferrous metals recovery from the ash raw material. Total amount of accumulated ash in the Ukraine exceeds 350 million tons and there are many deposits which contain more than 10 
million tons ash. Only a small part of coal ash and slag $(<10 \%)$ is of use in production of building materials. The coal ash constitutes a mixture of amorphous substances with as particle-size that depends on accumulation age. The ash is characterized by high silica content $(>50 \%)$, moderate content of $\mathrm{Fe}(12-15 \%)$ and aluminum oxide $(20-22 \%)$, and by low content of $\mathrm{Ca}, \mathrm{Na}$ and $\mathrm{K}$. The coal ash contains many toxic metals like $\mathrm{Cr}, \mathrm{V}, \mathrm{As}, \mathrm{Se}, \mathrm{Tl}, \mathrm{Cd}, \mathrm{Pb}$, Th and others. However, the most hazardous to the environment are $\mathrm{As}, \mathrm{Se}, \mathrm{Zn}$, and $\mathrm{Cd}$ because these elements form watersoluble compounds when the coal ash interacts with water. The coal ash also contains rather high concentrations of $\mathrm{Li}$, $\mathrm{Rb}, \mathrm{Cs}$, rare-earth metals, $\mathrm{Ga}, \mathrm{Pd}$ and other metals which are of great practical significance. The biggest ash-dumps of Ukraine can contribute all of the world's requirements in $\mathrm{Rb}$, $\mathrm{Cs}, \mathrm{Sc}$ and some other rare metals. Processing of the ash can be economically feasible if most valuable non-ferrous metals are extracted from the raw material. The distribution, accumulation, and chemical composition of non-ferrous metals in ash minerals is also discussed.

\section{The Behavior of Rocket-Fuel Components in Soil and Plants in Kazakhstan and Altay Region in Russia}

\author{
KASIMOV, N.S., KOROLEVA, T.V., PROSKURYAKOV, U.V., \\ VOROGEYKIN, A.P. \\ Geographic Faculty, Moscow State University, Moscow, Russia
}

Since the launching of space rockets began at the end of the $1950 \mathrm{~s}$, tens of thousands of square kilometers have been subject to continuing contamination by highly toxic rocket fuel. It falls to Earth from the first and second stages of rockets launched from the space center at Baykonur. The zones impacted by the rocket fuel remnants are usually ellipses with areas of several hundred square kilometers and represent zones of heightened ecological risk. Unsymmetric dimethylhydrazine (UDMH) and its derivatives are among the most important toxic agents released from rocket fuel. UDMH is taken up most heavily by the vegetation. The extent of UDMH accumulation by plants depends on the taxonomic families of the plants, the geochemistry of the sites where they are growing, proximity to the sources of UDMH contamination, and the amount of fuel deposited on the surface of soil and the plants themselves. The UDMH content of plants in the rocket-launch reservations varies from $0.05 \times 10^{-4} \mathrm{~g} \mathrm{~kg}^{-1}$ to $224 \times 10^{-4} \mathrm{~g} \mathrm{~kg}^{-1}$, and the concentrations measured most often fall in the range of $0.2 \times 10^{-4} \mathrm{~g} \mathrm{~kg}^{-1}$ to $0.3 \times 10^{-4} \mathrm{~g} \mathrm{~kg}^{-1}$.

Soils are not as heavily contaminated as plants. The most important chemical characteristics of soils affecting the movement and concentration of UDMH are their acid-alkali and oxidation-reduction conditions, humus content, and their adsorption capacity. The UDMH content of the soils ranged from $0.05-18 \times 10^{-4} \mathrm{~g} \mathrm{~kg}^{-1}$, with the most frequent readings falling between $0.05 \times 10^{-4}$ and $0.1 \times 10^{-4} \mathrm{~g} \mathrm{~kg}^{-1}$ (MPC for soils is $0.1 \times 10^{-4} \mathrm{~g} \mathrm{~kg}^{-1}$ ).

\section{Arsenic Exposure in SW England, UK: Significance for Human Health.}

\author{
KAVANAGH, P.J.' , FARAGO, M.E. ', THORNTON, I.', \\ GOESSLER, W. ${ }^{2}$ and IRGOLIC, $K .^{2}$ \\ 'Environmental Geochemistry Research Group, Centre for \\ Environmental Technology, Imperial College, Prince Consort \\ Road, London, SW7 2BP, UK \\ ${ }^{2}$ Institute for Analytical Chemistry, Karl Franzens Universität, \\ Graz, Universitatplatz I, Graz A8010, Austria
}

A pilot study has been conducted to determine the urinary As species present in first void samples of 31 male volunteers. The study population comprised residents of an abandoned As and Cu mine known as the Devon Great Consols and residents of the adjacent historical mining village of Gunnislake. A control population was chosen from the nearby village of Cargreen, which has no history of mining or smelting. Soils in the study area are highly contaminated (mean $365 \mu \mathrm{g} \mathrm{As} \mathrm{g}^{-1}$, range 120-1695 $\mu \mathrm{g}$ As $\mathrm{g}^{-1}$ ) compared to those of the control site (mean $40 \mu \mathrm{g} \mathrm{As}^{-1}$, range 25-136 $\mu \mathrm{g} \mathrm{As}^{-1}$ ). Total As levels were determined also in samples of potable water, house dust, human hair and garden vegetables. Urinary As species were separated by ion exchange and determined by ICP-MS (inductively coupled plasma-mass spectrometry). Total As concentrations in house dusts and soils were found to be higher in samples from the Devon Great Consols compared to those of Gunnislake village, which in turn were appreciably higher than those from Cargreen.

Residents in the areas with high soil As appear to excrete larger daily amounts of inorganic As (range 0.36 $8.51 \mu \mathrm{g} \mathrm{g}^{-1}$ creatinine) and dimethylarsinic acid (1.93 - 54.3 $\mu \mathrm{g} \mathrm{g}^{-1}$ creatinine) than residents of the control area, where these species were generally beneath the detection limit.

\section{Solubilization Of Heavy Metals (Cd, Ni, Pb) During Percolation Of The Chelating Agent EDTA Through Polluted Soils And Sediments}

KEDZIOREK, Monika A. M. and BOURG, Alain C. M.
Laboratory of Aquatic and Environmental Sciences, University of
Limoges, I23 Ave. Albert Thomas, 87060 Limoges Cedex, France

Since the chelate EDTA is one of the most widely used complexing agents, it is now found in many natural waters, the highest concentrations typically being observed at the outlet of waste water treatment plants. This presence raises the concern of possibly increasing the solubility and consequently the mobility of toxic metals in the hydrosphere. Three types of polluted solids (a mining residue, a sandy surface soil and a river sediment) were percolated in column laboratory experiments with aqueous solutions containing various concentrations of EDTA, ranging from ca. $4 \times 10^{-5}$ to $4 \times 10^{-4} \mathrm{M}$.

The solubilization of heavy metals increases with the concentration of EDTA (e.g., for a ten-fold increase in 
EDTA, $\mathrm{Cd}$ and $\mathrm{Pb}$ are 400 and 6 times more soluble, respectively). The quantity of metal solubilized depends on the nature of the solid. For example, the highest concentrations of $\mathrm{Pb}$ solubilized are $3 \mathrm{mg} \mathrm{L}^{-1}$ for the mining residue, 6 ... $\mathrm{L}^{-1}$ for the sandy soil and $0.2 \mathrm{mg} \mathrm{L}^{-1}$ for the Lot River sediment. However, even at the highest EDTA concentration the fraction of metal remobilized from the solids is very low.

The percolation of the aqueous EDTA solution through the columns involves not only the solubilization of toxic heavy metals but also possibly the dissolution of part of the solid matrix (for our samples: none for $\mathrm{Ca}$, very little for $\mathrm{Mn}$ and a little for $\mathrm{Fe}$ ).

In conclusion, percolation of a pulse of EDTA (of a concentration typical of a sewage outlet) does not significantly modify the composition of the solid matrix but it can solubilize heavy metal concentrations far in excess of drinking water standards.

\section{Natural Acid Drainage Associated with Shale-Hosted Ag-Pb-Zn Massive Sulfide Deposits in the Brooks Range, Northern Alaska, USA}

KELLEY, K. D.

U.S. Geological Survey, MS 973, Box 25046, Denver, Colorado, 80225, USA

Red Dog, Lik, and Drenchwater are shale-hosted stratiform $\mathrm{Ag}-\mathrm{Pb}-\mathrm{Zn}$ massive sulfide deposits in northern Alaska. The Red Dog deposit, mined since 1990, contains the largest zinc reserves in the world. The compositions of surface waters collected from Red Dog prior to mining were compared to natural drainage compositions from the Lik and Drenchwater deposits, which have not yet been mined. The primary factors affecting water chemistry are the extent of surface exposure of the deposits, the ore grade, the amount of carbonate rocks in the area, and the proportion of ironsulfide in the ore. Surface water samples from Drenchwater, which is pyrite-dominant, have $\mathrm{pH}$ values as low as 2.8 and high dissolved metal concentrations including $95,000 \mu \mathrm{g} \mathrm{L}^{-1}$ $\mathrm{Al}, 270,000 \mu \mathrm{g} \mathrm{L}^{-1} \mathrm{Fe}, 26 \mu \mathrm{g} \mathrm{L}^{-1} \mathrm{As}, 8 \mu \mathrm{g} \mathrm{L}^{-1} \mathrm{Cd}, 10 \mu \mathrm{g} \mathrm{L}^{-1}$ $\mathrm{Pb}$, and 2,600 $\mu \mathrm{g} \mathrm{L}^{-1} \mathrm{Zn}$. Sulfate concentrations are also high (up to $1,180 \mathrm{mg} \mathrm{L}^{-1}$ ). Locally, stream pebbles and cobbles are coated with a bright-orange material. This material is dominantly jarosite, precipitated from the ironand sulfate-rich waters.

Pre-mining surface waters from Red Dog were acidic (pH of 3.5), with maximum $\mathrm{Pb}, \mathrm{Zn}$, and $\mathrm{Cd}$ concentrations of $2,100 \mu \mathrm{g} \mathrm{L}^{-1}, 40,400 \mu \mathrm{g} \mathrm{L}^{-1}$, and $396 \mu \mathrm{g} \mathrm{L}^{-1}$, respectively. Higher metal concentrations in Red Dog waters relative to Drenchwater reflect the higher ore grades and the abundant sphalerite, pyrite, and galena that were present in outcrop at Red Dog prior to mining. In contrast, despite significant mineralization at the Lik deposit, carbonate rocks in the area buffer the waters, resulting in near neutral $\mathrm{pH}$ with low concentrations of most metals except zinc.

\section{Moisture and Salinity Limits on Pyrite Oxidation in Semi-Arid Climates}

KEMPTON, J. H., COOK, T. L., ATKINS, D. A., and McHUGH, M. PTI Environmental Services, 4940 Pearl East Circle, Suite 300, Boulder, CO 8030I, USA

Despite considerable research on pyrite oxidation, the relation between water content in mine waste and oxidation rate has not been evaluated. Sulfide oxidation rates were determined at a variety of moisture contents by directly measuring the rate of oxygen consumption in crushed and sieved rock sealed in columns. Results showed that the sulfide oxidation rates were correlated to both sulfide and gravimetric moisture contents. Oxidation rates in two highly sulfidic samples ( 7 and $13 \%$ sulfide) increased from $10 \mathrm{~mol}$ $\mathrm{O}_{2} \mathrm{~m}^{-3} \mathrm{a}^{-1}$ to over $40,000 \mathrm{~mol} \mathrm{O}_{2} \mathrm{~m}^{-3} \mathrm{a}^{-1}$ as moistures increased from $<0.005 \%$ to $5 \%$. $85 \%$ of this increase occurred between 1 and $2 \%$ moisture. Above $2 \%$ moisture, oxidation rates leveled out or decreased. In contrast, the oxidation rate of two low-sulfide samples ( 1 and $0.005 \%$ sulfide) increased consistently with increasing moisture, from 6 to $500 \mathrm{~mol} \mathrm{O}_{2}$ $\mathrm{m}^{-3} \mathrm{a}^{-1}(0.005 \%$ sulfide $)$ and from 6 to $3,000 \mathrm{~mol} \mathrm{O}_{2} \mathrm{~m}^{-3} \mathrm{a}^{-1}$ ( $1 \%$ sulfide). The results suggest that sulfide oxidation in waste rock can be significantly reduced by maintaining moisture at $<1 \%$. However, near-surface soil moisture in waste rock is typically $>2 \%$, even in semi-arid climates, indicating that moisture contents are probably not limiting oxidation rates in uncovered waste rock. Parallel experiments conducted to examine the effect of pore-water salinity on oxidation rates found no decrease in oxidation rate over a 4-month period.

\section{Heavy Metal Contamination in Dusts and Stream Sediments in the Taejon Area, Korea}

KIM, Kyoung-Woong', MYUNG, Jae-Hoon ${ }^{2}$, and CHON, Hyo-Taek ${ }^{2}$ 'Department of Earth Resources and Environ. Engineering, Paichai University, Taejon 302-735, Korea

${ }^{2}$ Department of Mineral and Petroleum Engineering, Seoul National University, Seoul 151-742, Korea

An investigation was made of the concentrations of $\mathrm{Cd}, \mathrm{Cu}$, $\mathrm{Pb}$ and $\mathrm{Zn}$ in 81 road dusts and 21 stream sediments in the Taejon area. Copper, $\mathrm{Pb}$ and $\mathrm{Zn}$ levels in road dusts from the control area are lower than the permissible levels, although those from the traffic and industrialized areas are relatively high. The highest lead concentration in road dust, $161 \mu \mathrm{g} \mathrm{g}^{-1}$, was noted in a sample from Yusung Motorway Junction. The calculated urbanization and industrialization index was found to correlate with the pollution index of multi-element contamination in road dusts. Elevated levels of $\mathrm{Cd}, \mathrm{Cu}, \mathrm{Pb}$ and $\mathrm{Zn}$ are also noted in stream sediments from the Taejon Industrial area. The highest $\mathrm{Zn}$ concentration ( $387 \mu \mathrm{g} \mathrm{g}^{-1}$ ) was found in the sediment close to the Sintanjin Industrial area. A sequential extraction procedure 
applied to stream sediments indicates a high percentage of easily extracted metals. The extractable phase of the metals may originate not from parent materials but from wastewater and exist as an adsorbed phase on the surface of sediments. These metals are easily dissolved into the water and the relative amounts of the dissolved phase are in the order of $\mathrm{Cu}=\mathrm{Zn}>\mathrm{Pb}$.

\section{The Effects of Glacial Dispersal and Glacial Process on Till Geochemistry, Labrador, Canada}

\section{KLASSEN, Rodney A.}

Geological Survey of Canada, 601 Booth St., Ottawa, ON, Canada, K1A OE8.

In western Labrador, Canada, regional scale (100's of km) variations in till geochemistry reflect bedrock composition as well as differences in ice flow trend and intensity of glacial processes among glacial events. The area straddles high-grade metamorphic terrain of the Superior Geological Province, and softer, supracrustal sedimentary and volcanic bedrock of the Labrador Trough in the Churchill Province. It is situated near one or more dispersal centers of the Labradorean Sector of the Laurentide Ice Sheet and has experienced a complex history of changing ice flow, defined by striations and by transport pathways inferred from indicator erratics. Compared to till derived from metamorphic terrain, Labrador Trough till is finer-grained, enriched in $\mathrm{Fe}, \mathrm{Mn}, \mathrm{Pb}$, and $\mathrm{Zn}$, and depleted in $\mathrm{Ni}$ and $\mathrm{Cr}$. From oldest to youngest, three events control drift composition: (1) northeastward-southeastward flow associated with an ice divide in the Trough, (2) north-northeastward to northwestward flow toward Ungava Bay affecting only the northern area, and (3) eastward flow affecting only the southern; demarcation between the areas affected by Events 2 and 3 is well defined. Glacial dispersal trains defined by geochemical analysis and indicator erratics that are associated with Event 1 extend $>50-100 \mathrm{~km}$ across the Superior Province. In the area affected by Event 2, debris in the ice was redirected northward several 10's of $\mathrm{km}$, and till composition remained unaffected due to either limited or no subglacial erosion. In contrast, Event 3 was highly erosive and removed the compositional record of Event 1; it is associated with the head of an ice stream.

\section{A Comparison of Regional Geochemical Surveys of Till and Lake Sediment, Labrador, Canada}

\author{
KLASSEN, Rodney A., RENCZ, A.N., and MOORE, A. \\ Geological Survey of Canada, 601 Booth St., Ottawa, ON, KIA \\ $O E 8$
}

Geochemical analyses results for till (2438 samples) and lake sediments ( $>12,000$ samples), obtained as part of regional surveys in support of mineral exploration in central Labrador, Canada $\left(52^{\circ}-57^{\circ} \mathrm{N}, 57^{\circ}-69^{\circ} \mathrm{W}\right)$, were compared to determine regional differences and similarities between those sample media. The till data were compared to lake sediment data modeled on a $2 \mathrm{~km}$ grid. The elements $\mathrm{Cu}, \mathrm{Zn}, \mathrm{Ni}, \mathrm{As}$, and $\mathrm{Mn}$ were chosen for study; the metals $\mathrm{Cu}$ and $\mathrm{Ni}$ because of their application to mineral exploration; $\mathrm{Zn}$ and As because of their affinity for organic material; and Mn because of its mobility in the surficial environment and potential to reflect physical and chemical differences among lake basins. Spatial variations in geochemical data for both sample media reflect regional variations in bedrock geology; none is obviously attributable to anthropogenic input. For example, $\mathrm{Cu}$ in both till and lake sediments was highest in mafic volcanic terrain of the eastern Labrador Trough. Unexpected, however, were areas of significant differences and the systematic regional variations in the relative concentrations of trace metals between the two sample types, illustrated by trace metal ratio maps. In part the differences are attributed to both physical and chemical factors related to: (1) grain size and mineralogy of surficial deposits in the drainage basin, and their effects on clastic sedimentation in lakes, (2) climatic and vegetation differences, an interpretation supported by regional differences in the organic matter content of lake sediments, and (3) physiographic differences. From this, factors other than bedrock are important to the interpretation of metal variations in lake sediments.

\section{Metal Fluxes and Accumulation in Lakes of Latvia}

\author{
KLAVINS, M., KLAVINA, I., and RODINOV, V. \\ University of Latvia, Raina Blvd. 19, Riga, LV 1568, Latvia
}

Data on atmospheric deposition, transport from run-off water, and the chemistry of lake waters and sediments were used to estimate the fluxes of trace metals in 86 lakes of Latvia. In the same water bodies the metal concentrations in macrophytes, mussels, crayfish, and fish were determined and the metal bioaccumulation pattern has been evaluated. The high concentrations of humic substances (HS) in both lake waters and sediments was investigated and their binding capacity with metal ions was evaluated along with the complex forming process between metals and HS. HS has been isolated from sediments of lakes, with different trophic states, from Latvia. The isolated HS has been characterized by their elemental, functional composition, their UV and IR fluorescence, and BPR spectra. The molecular mass of HS and their metal binding ability has been determined. Complex forming properties of HS with different origins has also been studied.

The dominating pathways for different metals has been evaluated stressing the impact of land-use on metal accumulation processes. The metal concentrations in waters and sediments in biota were compared with similar materials in other water bodies and the impact of water chemistry, landuse and other natural conditions on metal accumulation patterns and fluxes will be discussed. 
Measurement of Gas Exchange Processes Between Soils and the Atmosphere and Applications in Environmental and Exploration Geochemistry

\author{
KLUSMAN, Ronald W., JAKEL, M. Emmellyn, and LeROY, \\ Michael $P$. \\ Department of Chemistry and Geochemistry, Colorado School of \\ Mines, Golden, CO 80401, USA
}

Soil gas concentration measurements have been made for a considerable length of time in both environmental and in exploration geochemistry. More recently, the rate of exchange of soil gases with the atmosphere has been applied to environmental studies, particularly in global climate change. These measurements are critical in quantifying the biogeochemical cycle for radiatively active gases, and the anthropogenic modification of the balance.

The most critical of the radiatively active gases are carbon dioxide and methane. Much of the research on atmospheric exchange of soil gas carbon dioxide and methane has focused on near-surface processes occurring in soils. Generally, the role of geology and geological processes has been ignored in the exchange of these gases with the atmosphere.

Data will be presented which demonstrates that geologic processes cannot be ignored for the exchange of these two important gases with the atmosphere. Measurement of methane exchange with the atmosphere in arid and semiarid basins suggests that thermogenic methane may leak to the atmosphere during drier periods of the year. This is contrary to the conventional wisdom about methane exchange used in climate models.

Additional measurements of carbon dioxide exchange in the Basin and Range of the western United States indicate that areas of high heat flow may leak unexpectedly large amounts of carbon dioxide to the atmosphere. Flux rates of carbon dioxide to the atmosphere in some arid geothermal environments may approach that expected for soil respiration in wet climates, and during the wettest season. The measurements of carbon dioxide and methane fluxes suggest that widely spaced measurements that are extended to large areas of the Earth's surface are subject to considerable error. These measurements also have implications for the potential extension of soil gas measurements to the exploration for geothermal energy resources, mineral deposits, and surface geochemistry applied to petroleum exploration.

\section{A Geochemical Investigation of the Water and Sediments of Barber's Pan, North West Province}

KNESL, Oliver, FEY, Martin V. and WILLIS, James $P$. Department of Geological Sciences, University of Cape Town, Rondebosch, 7700, South Africa

Barber's Pan, a RAMSAR site, is a shallow, alkaline, 1,750 ha lake earmarked for special conservation measures in the North West Province of South Africa. Water and sediment (van Veen grab) samples were collected at nine sites across the pan. Electrical conductivity, $\mathrm{pH}$, alkalinity, ion and elemental concentrations (including $\mathrm{Si}$ and $\mathrm{P}$ ) were determined in the supernatant and interstitial waters and compared with historical data spanning 15 years of monitoring. The geochemical model MINTEQA2 was used to calculate ion speciation and mineral saturation indices. The bulk pan water is well mixed, having a uniform composition throughout. The water is alkaline $(\mathrm{pH} 7.9-8.5)$ and subsaline (EC $1.9 \mathrm{dS} \mathrm{m}^{-1}$ ), with $\mathrm{Na}, \mathrm{Cl}^{-}$and $\mathrm{HCO}_{3}^{-}$as the dominant ions. The pan water is unusual in that $\mathrm{Mg}$ concentrations dominate over Ca. The interstitial water is also very homogeneous, but contains higher concentrations of most solutes than the bulk pan water. Exceptions are $\mathrm{Al}$ and $\mathrm{SO}_{4}{ }^{-2}$, both being at lower concentrations in the interstitial water. MINTEQA2 calculations showed that the water is supersaturated with respect to a number of calcium minerals including calcite, dolomite, hydroxyapatite and fluorapatite. Phosphate activity was consistent with fluorapatite and hydroxyapatite solubility. The results suggest that levels of dissolved nutrients such as $\mathrm{P}, \mathrm{Ca}$ and $\mathrm{Si}$ are not necessarily biologically controlled since they are consistent with those expected in equilibrium with minerals in the sediments (apatite, calcite and smectite).

\section{Environmental Geochemical Mapping in the Ukraine}

KOMOV, I.L., POLICHTCHOUK, J.V., BURLAK A, V. 34, Palladin pr., Kiev-142, Ukraine

A mapping procedure applicable in the compilation of detailed environmental geochemical maps is presented. It is based on the delimitation of elementary geochemical landscape areas which are characterized by the specific association of landscape forming factors (climate, geology, petrology, geomorphology, soil cover ). Traditional mining and exploration techniques in the past have in many cases caused environmental problems. Through the application of mineral exploration methods that have low environmental impact, the mining industry has overcome may of its earlier pollution problems. A comparative before and after mining study of the levels of various pollutants at and near mining sites indicate that particular pollutants may significantly accumulate at specific mine sites only. This paper examines the influence of naturally occurring uraniferous black shales 
on the chemical composition of soil and plants and possible implications to human health. Some of the potentially toxic elements of concern to man are present in naturally occurring rocks. Elements in the black shales have been enriched by direct precipitation of sulfides and fixation by organic matter. Additional metal may have been added by epigenetic and anthropogenic agents. Black shales in Ukraine are a natural geochemical source of trace elements such as $\mathrm{Cd}$, $\mathrm{Mo}, \mathrm{Se}, \mathrm{U}$, which may be present in concentrations toxic to animal and human health. Soil derived from black shales tend to reflect their extreme geochemical composition. Numerous data have been summarized on the set of maps. The maps are at the scale 1:50,000 and summarize all the accessible data on geology, soils, natural resources, surface and ground waters and environmental factors. The objective of this set of maps to bring new information, also to give detailed data necessary for an effective management of land resources, for urban and regional planning, for planning of development of agriculture and forestry, for land use planning, and for planning of recreational areas.

\section{Geochemistry of Mercury and Trace} Elements in Organic-Rich Sediments and Vegetation from the Everglades, South

\section{Florida}

KOTRA', Rama K. and GOUGH', Larry P.

'U.S. Geological Survey, 954 National Center, Reston, VA 20192, $U S A$

${ }^{2}$ U.S. Geological Survey 973 Denver Federal Center, Denver, CO 80225, USA

Recent concern regarding high levels of mercury in fish and nutrient enrichment in south Florida ecosystems has provided an impetus for studies of the geochemical processes influencing the distribution and cycling of environmentally important elements. Knowledge of regional and recent historical element variations is essential for a comprehensive understanding of current and past geochemical processes. Preliminary results from peat-dominated sediment core samples and sawgrass (Cladium jamaicensis) samples show that metabolic elements (e.g., K, P, Cu, Fe and $\mathrm{Zn}$ ) are concentrated in living tissue relative to the sediment and non-essential metals (e.g., $\mathrm{Cr}, \mathrm{Co}, \mathrm{Pb}$ and $\mathrm{Hg}$ ) are concentrated mainly in the sediment relative to sawgrass. Accumulation rates for metals in sediment show a general decrease with depth in the peat cores. For a set of cores accumulation rates appear to vary along a $45 \mathrm{mi}$. northeast-southwest transect beginning in Water Conservation Area 2-A and progressing into Everglades National Park. For example, whereas rates for $\mathrm{Ni}, \mathrm{V}$, and $\mathrm{Zn}$ show only subtle difference between sampling sites, $\mathrm{Pb}$ is highest in the near surface layers of cores from the south. Baseline values for metal concentrations in sediments collected in the south Florida study area seem to be attained in core material that is about 100 years old. The geochemistry of upper core material from sediment collection sites further west in Big Cypress
National Preserve show lower levels of trace metals and may be reflective of more pristine conditions.

\section{Ore Fields, Deposits, and Zones of Deep Faults As Probable Geo-Pathogenic Biogeochemical Provinces and Belts}

\author{
KOVALEVSKII, Alexander L. and LBOV, Alexander V. \\ Buryat Geological Institute Siberian Branch Russian Academy of \\ Sciences, Ulan-Ude, 670047 Russia
}

Zones of deep faults, ore fields and ore deposits are extensively studied by geologists. The information about them always has great ecological significance. It is too bad that geologists do not conduct ecological-biogeochemical studies of their field areas.

Our experience has shown that all ore deposits are accompanied by complex haloes of chemical elements that are "non-barrier" in their uptake by plants (Kovalevskii, 1960-1996, Russian; Kovalevskii, 1963-1995, English). Biogeochemical anomalies of the halo-forming elements are much more (10-100 times greater) than the non-halo elements. Usually it is not the mined element that is of ecological concern, but of associated elements. Mercury is of especial concern and $\mathrm{Cd}$ and As to a lesser degree. All can migrate as gases.

Mercury forms intensive biogeochemical haloes in all of the investigated deposits and ore occurrences of $\mathrm{Fe}, \mathrm{Mo}, \mathrm{W}$, $\mathrm{Be}, \mathrm{Li}, \mathrm{Rb}, \mathrm{F}, \mathrm{Pb}, \mathrm{Bi}, \mathrm{Sb}, \mathrm{As}, \mathrm{Tl}, \mathrm{U}, \mathrm{Zn}, \mathrm{Cd}, \mathrm{Hg}, \mathrm{Cu}, \mathrm{Ag}, \mathrm{Au}$, $\mathrm{Pt}, \mathrm{Pd}, \mathrm{Rh}, \mathrm{Ir}, \mathrm{Os}$ and for deposits of oil and gas. Biogeochemical anomalies of $\mathrm{Hg}$, that have exceeded the limited permissible concentration (LPC), are characteristic of almost all investigated ore deposits of Siberia. Ecologically dangerous biogeochemical haloes of $\mathrm{Hg}$ form as complex linear, arc and ring fields. It is established that $\mathrm{Hg}$ forms biogeochemical anomalies far from the limits of the ore-bearing geology. Because of this, clustered deposits result in continuous anomalous regions of $\mathrm{Hg}$ in plants. These may correspond to regional $\mathrm{Hg}$-biogeochemical provinces. Determinations of $\mathrm{Hg}$ in soils and rocks usually do not give this important information and may bring misinformation about the ecological conditions of the orebearing terranes (Kovalevskii, 1981 - 1996; Kovalevskii, 1986-1993). Connected together, regional mercurybiogeochemical and mercury-hydro-biogeochemical provinces may form the global mercury-biogeochemical belts (Kovalevskii, in press, Russian).

The unique, but still uncontoured, biogeochemical As province of more than $6000 \mathrm{~km}^{2}$ was revealed by G.P. Lapaev in Jakutia using aquatic mosses. In many areas concentrations of As exceed the LPC. High-anomalous concentrations were also found for $\mathrm{Pb}, \mathrm{Zn}, \mathrm{Cd}, \mathrm{Tl}, \mathrm{Sb}$, and $\mathrm{Bi}(\mathrm{Hg}$, unfortunately, was not determined).

A very significant area $\left(>20,000 \mathrm{~km}^{2}\right)$ of hydrogeochemically anomalous $\mathrm{Cd}$ (from 1 to 60 times the LPC) was unexpectedly found in investigations of well water from drill holes in Buryatia (Plyusnin, in press in Russian). The 
region is in the central part of a major tectonic seam more than $1200 \mathrm{~km}$ long and may prove to have very important ecological-hydro-geochemical characteristics.

The report will also include data from a geo-pathogenic ovince associated with the biggest polymetallic deposit in Buryatia.

\section{Ecological-Biogeochemical Status of the Baikal Region, Russia}

KOVALEVSKII, Alexander, L.

Buryat Geological Institute Siberian Branch Russian Academy of Sciences, Ulan-Ude, 670047 Russia

This report is the result of our 32-year investigation of the Baikal Region. It is based on the results of field and laboratory studies in 112 experimental localities including 120,000 samples of plants, animals, soils, rocks, ores and waters and about 3 million determinations for 45-72 chemical elements. More than 800 bio-objects (plants and animals) were investigated. Numerous publications were issued (Kovalevskii, 1960-1996, Russian; Kovalevskii, 1963-1995, English).

The main factors governing the Baikal Region's ecological-biogeochemical status are its location in the central part of Asia, its long distance from maritime influences, and its geologic setting-especially, the wide distribution of acid rocks and their sandy weathering products. Geology controls the chemical composition of water-the main initial link to the biogeochemical cycling of elements. The "ultra-fresh" waters are deficient in $\mathrm{Ca}, \mathrm{Mg}, \mathrm{I}, \mathrm{F}, \mathrm{Se}$ and other vitally-necessary chemical elements. Some water supply sources, also geologically controlled, have excesses of $\mathrm{Fe}, \mathrm{Zn}, \mathrm{Cd}, \mathrm{Hg}, \mathrm{Pb}, \mathrm{Sr}, \mathrm{F}$. The natural areal deposition exceeds the limited permissible concentration (LPC) (Kovalevskii, 1984-1996, Russian; Kovalevskii, 1986-1994, English). These concentrations are also associated with known ore deposits at Ozernoe, Cholodninskoe, Gilbery, and Monostoi. In general, however, the Baikal Region is deficient in I, Se, F, Ca, Mg, P, 5, Mn, Co, Ni, Cu, Zn. The most significant regional environmental health problem is the general deficiency of I, Se, and F. The problem of I deficiency was recognized in 1960 by the USSR Ministry of Health. The problems of Se and $F$ deficiencies may result in very unfavorable economic regional consequences.

The areas with excesses of toxic chemical elements in the Baikal Region are more local as compared with the regional aspect of element deficiencies. Elemental excesses are connected mainly with numerous ore deposits and with local anthropogenic pollution near industrial facilities. The greatest contributor is from "mercury breathing" of the Earth associated with deep tectonic faults. Most troubling, however, are preliminary data that suggest significant pollution of waters by $\mathrm{Hg}$ in the north cup of Baikal Lake between the towns of Nizhneangarsk and Severobaikalsk.

\section{Fine Dust (PM10) Composition in a Major City: Mineralogy, Lead-Isotope and PAH- Composition in Vienna}

\author{
KRALIK, Martin, HOOGEWERFF, Jurian A., and ROTTER, \\ Heinrich \\ Federal Environment Agency and Research Centre Arsenal Ltd., \\ Vienna, Austria
}

Due to improved filtering techniques industry reduced the coarse dust emission considerably in Central Europe, the very fine grained $(<10 \mu \mathrm{m})$ and more dangerous dust emission stayed constant or has even increased. Because of their small size as well as their shape, dust particles may be particularly harmful to the human respiratory system. High concentrations of some minerals themselves (asbestos, quartz etc.) or the high heavy metal content as well as carcinogenic organic compounds (polyaromatic hydrocarbons, or PAH's) frequently attached to them have noxious effects.

The most important natural and manmade particle sources in urban environments are materials eroded by wind (soils, construction materials), as well as industrial and traffic emissions. Speculation about their sources has mostly been on the basis of chemical information only. Very little is known about their mineral and organic phases. To interpret the physical properties of particles, their environmental behavior and the health risks they may pose in the future, the combined information of chemistry and mineralogy is essential.

Methods: The very fine-grained particles have been collected on 'low blank' cellulose nitrate and glass-fiber filters in a high volume sampler (Stroehlein) or in a cascade impactor (CMI). To observe long term changes, samples have been taken from the filter of an air conditioner in intervals of 3-5 months from 1991-1995. These samples have been dry-screened to $<20 \mu \mathrm{m}$, to make them comparable to the PM10 filter samples. Mineralogical composition was analyzed by $x$-ray diffraction, FTIR and SEM. The trace element and $\mathrm{Pb}$-isotope composition was obtained by dissolving parts of the filters and subsequent analysis with ICP-MS. Glass-fiber filters were extracted with supercritical $\mathrm{CO}_{2}$ and the PAH's were analyzed with GC-MS. Some of the dust samples of the air conditioner filters were analyzed for $\mathrm{C}$-, and $\mathrm{S}$-isotopes by high-resolution mass spectrometry to determine the distribution of sources, done by traceelement chemistry previously.

Results: The dust samples consist of calcite, dolomite, quartz, organic matter (+ soot), and gypsum as major phases, whereas illite-mica, chlorite and feldspar are minor phases $(<5 \%)$. Magnetite, goethite, brushite and epsomite were detected as well. Winter samples are more enriched in calcite, dolomite and gypsum compared to samples collected during summer. The considerable enrichment in $\mathrm{As}, \mathrm{Cd}, \mathrm{Pb}$ and $\mathrm{Zn}$, compared with the mean crustal composition, as well as the lead isotope-ratios (207/026) indicate a fair mixture of emissions from heating and gasoline combustion during winter and a dominance of the latter during summer. 
The PAH pattern supports the conclusion drawn from the heavy metal analysis. The most prominent change during 1991-1995 is the considerable decrease in lead content, due the stop of leaded gasoline during this period.

\section{Unique Ground Water (Karst) Monitoring System as an Important Tool of Drinking Water Protection in Austria}

\author{
KRALIK, Martin, GRATH, Johannes, NAGY, Wilhelm, VOGEL, \\ Wilhelm and PHILIPPITSCH, Rudolf \\ Federal Environment Agency and Ministry of Agriculture and \\ Forestry, Vienna, Austria
}

Background: Karst ground water is one of the most important drinking water resources in Europe as well as in other parts of the world. The existing European regulations set high priorities to protection of the ground water for drinking water supply. In karstic areas composed principally of carbonate rocks-- $35 \%$ of Europe-- ground water is very often the only source of water supply. Many important cities such as Paris, Rome, Vienna, Innsbruck, Montpellier, Neuchatel, Rijeka, Thessaloniki etc. are partly or totally supplied with drinking water from karst aquifers. Due to their particular structure karst aquifers are more vulnerable to pollution than ground water in porous aquifers. The resulting complexity of the properties and the dynamics of karst aquifers make it even more important to run a monitoring system to detect pollution sources at an early stage to give time to set preventive measures.

The Austrian water quality monitoring system (AWQMS): New legislation and administrative procedures concerning water pollution are the basis for the AWQMS for ground water and running water since 1990. Federal and provincial authorities as well as a large number of private laboratories are involved in the monitoring system itself. As part of this AWQMS (altogether 2000 sampling sites) 130 major and smaller springs $\left(7-600 \mathrm{~L} \mathrm{~s}^{-1}\right)$ have been sampled four times a year since 1991 .

The Karst-water samples were analyzed for 45 major ions and inorganic and organic micropollutants. Special attention is paid to standardization and analytical quality assurance. Considering the aim of the AWQMS, the design of the monitoring network (e.g. location of the sampling sites) and the administrative framework the AWQMS integrates elements of background, impact, trends and compliance monitoring.

Results: One or more parameters exceed at 59 sampling sites $(45 \%)$ from time to time (due to the high rate of spring discharge) the ground-water limit values (generally $60 \%$ of the drinking water limit values). The drinking water values were exceeded temporarily in 8 springs $(6 \%)$ for $\mathrm{Al}, \mathrm{Hg}, \mathrm{Pb}$, and desethylatrazine. Despite the generally low concentrations of pollutants due to their sites in remote alpine areas, factor analysis allows us to discern the pollution sources at a very low level. Agricultural sources are characterized by elevated levels of $\mathrm{NO}_{3}$-atrazine-desethylatrazine. Sewage waters, however, are indicated by DOC-AOX- $\mathrm{PO}_{4}$, whereas $\mathrm{NH}_{4}-\mathrm{NO}_{2}-\mathrm{Pb}$ may be related to atmospheric pollution.

\section{Multistage Reflectance Spectroscopic Analyses of Central German Lignite Overburden Dumps (First Results)}

\author{
KRÜGER, G., KAUFMANN, H., AND ERZINGER, J. \\ GeoForschungsZentrum Potsdam, Telegrafenberg A17, D-14473 \\ Potsdam, Germany
}

To provide the former GDR with domestic energy, extensive open pit lignite mining was performed over several decades. After the German reunification the demand for lignite declined drastically. Most mines are already abandoned and as a consequence there is a immediate need for recultivation and reclamation of the devastated areas. As a base for a proper recultivation a comprehensive knowledge of the dumped overburden sediment composition and the chemical processes within the dumps is essential. Typical Central German dumped lignite overburden is composed of a mixture of Tertiary and Quaternary sedimentary facies. Collected field samples show high contents of quartz accompanied by smaller amounts of clay minerals and organic matter. Once the overburden is dumped pyrite is oxidized, carbonates are decomposed and minerals like gypsum, jarosite, and aluminite are formed.

Imaging spectrometry as a new remote sensing technique is a promising tool for the characterization of dumped overburden due to a synoptic view of the entire target at high spectral resolution. Many of the minerals present, such as clays, carbonates, sulfates, and organic matter, display diagnostic spectral signatures in the reflective wavelength region (visible, near and short-wave infrared; $0.4-2.5 \mu \mathrm{m}$ ). Thus, discrimination and identification of distinct materials in the lignite overburden is feasible and is demonstrated by a combined analysis of laboratory, field and airborne spectral measurements. In addition, an approach for quantification from laboratory reflectance spectra is presented, using chemical and mineralogical analyses of field samples for calibration. The transferability of the evaluation methods from laboratory to field and airborne data is discussed; risks and limitations are pointed out. The airborne sensor used in this project is DLR's DAIS 7915. It records the reflected sunlight and the thermally emitted radiation in 79 narrow, mostly contiguous channels. 


\section{Rehabilitation-Induced Vegetation} Progression at a Gypsum Mine in Western Rajasthan-Analytical Approaches and Impirical Evidence

\author{
KUMAR', Suresh, GOUGH', Larry P., SHARMA', K.D., and \\ SHARMA', B.K. \\ 'Central Arid Zone Research Institute, CAZRI, Jodhpur 343003 , \\ India \\ ${ }^{2}$ U.S. Geological Survey, Denver, CO 80225, USA
}

Gypsum is surface mined near the village of Barmer in the Great Indian Desert, western Rajasthan. After mining, the barren surface is normally left untreated (without overburden replacement or soil enhancement) and is prone to wind erosion and invasion by noxious weeds. In order to evaluate the rehabilitation of these lands for animal grazing potential, a combination of three water harvesting treatments (microcatchments, ridge-and-furrows, and half-moon structures) was tested along with various mixtures of both endemic and non-native plant species. Non-planted, naturally regenerated species are important to plot species dynamics and were also evaluated. Beginning in 1992, four ha $\mathrm{a}^{-1}$ have been rehabilitated (including a control plot). Using transects, we evaluated revegetation success in one-year old (RP-1) and fouryear old (RP-4) plots. RP-4 showed a greater decline in species abundance over RP-1. Significant differences in beta-diversity amongst treatments over the four years proved habitat differentiation. Dominance diversity trends indicate that there is more stability to the RP-4 plant community compared to RP-1. These trends along with the relationship of certain planted species to soil constituents (e.g., leguminous species to soil organic matter levels) are discussed.

\section{Metal Release and Recolonization Characteristics of Tailings in a Marine Environment - A Laboratory Study and Site Demonstration}

\author{
LAMBETH, R. H.' ${ }^{\prime}$ DRAKE, P. L. ${ }^{2}, K L I N E, E .^{3}$, and PAULSON, \\ A. $\mathrm{J}^{+}$ \\ 'Titan Environmental Corporation, 123 East Indiana Ave., Suite \\ 103, Spokane, WA, 99207, USA \\ ${ }^{2}$ NIOSH-Spokane Research Center, Spokane, WA, USA \\ ${ }^{3}$ University of Alaska, Southeast, Juneau, AK, USA \\ ${ }^{+}$Drexel University, Philadelphia, PA, USA
}

Very little is known about the postdepositional behavior of submerged tailings. However, disposal of mine tailings in natural waters of the US was prohibited by 40 CFR 440 . To better understand the metal release characteristics of submerged tailings and to provide Congress and regulatory agencies with information to re-evaluate this prohibition, researchers at the US Bureau of Mines (BOM) in 1993 and 1994 simulated the effects of submarine tailings disposal in a laboratory. Tailings from the Kensington Mine near Juneau, Alaska were placed in aquariums and covered with seawater under oxic and anoxic conditions. Dissolution of tailings was monitored by sampling the water above the tailings to detect the products of geochemical reactions that might affect toxicity. Samples of seawater without tailings were monitored as a control. $\mathrm{Cu}, \mathrm{Cd}, \mathrm{Pb}$, and $\mathrm{Zn}$ concentrations were less than the Alaska Aquatic Marine Criteria (MAC). The concentrations of $\mathrm{Pb}$ and $\mathrm{Zn}$ were highest in the seawater control, suggesting adsorption was removing these metals from the overlying water column. Manganese was initially released in concentrations above MAC under oxic and anoxic conditions. However, after approximately 100 days under oxic conditions, Mn concentrations decreased to less $10 \mu \mathrm{g} \mathrm{L}^{-1}$, a concentration well below MAC. Anoxic concentration remained above MAC.

Based on the favorable results of the laboratory simulation, BOM researchers determined that field verification was needed, and in late 1994 a site demonstration, which incorporated biologic studies, was initiated. Seven sample containers were filled with tailings and monitoring instruments. To permit comparison of tailings pore water chemistry with that of natural sediment, two additional containers were filled with dredged natural sediment from which all biota had been removed, and monitoring instruments were installed. To compare recolonization characteristics, 96 biosampling containers were filled with defaunated natural sediment or tailings surrounded by defaunated natural sediment. All containers were placed in 25 meters of water in Auke Bay and sequentially retrieved over a 16 month period.

Chemical analysis of pore water samples indicate that neither tailings nor natural sediment release $\mathrm{Cd}, \mathrm{Cu}, \mathrm{Pb}$, or $\mathrm{Zn}$ into pore water in concentrations which exceed $\mathrm{MAC}$, and there is no significant difference between natural sediment and tailings pore water concentrations of these metals. Most analyses were near detection limit. Mn and Fe are released to porewater in both tailings and natural sediment; $\mathrm{Mn}$ porewater concentrations of both exceed MAC. Average Mn concentration of sediment and tailings pore water is $700-800 \mu \mathrm{g} \mathrm{L}^{-1}$. For the final samples retrieved, average Fe concentration in sediment was $2,500 \mu \mathrm{g}$ $\mathrm{L}^{-1}$, whereas tailings was $580 \mu \mathrm{g} \mathrm{\textrm {L } ^ { - 1 }}$.

Results from the recolonization study indicate that there is no statistical difference in organism count or diversity between tailings and control sediment samples. Tailings and control sediment samples both contained a greater number of taxa and higher populations than ambient cores taken in the vicinity of the sight demonstration. These results indicate that the Kensington tailings may be capable of supporting benthic life. 


\section{Dispersal of Arsenic by Gold Mining Near Barberton, South Africa}

\author{
LANYON, Ruth, FEY, Martin V., WILLIS, James P., and \\ JAMIESON, Heather \\ Dept. of Geological Sciences, University of Cape Town, \\ Rondebosch, 7700, South Africa
}

Arsenopyritic rock and slimes are disposed of at the Barbrook gold mine in a manner which requires careful arsenic monitoring in surface and ground water. The greatest potential for As mobilization was found to be associated with reducing conditions affecting tailings dam leachate. High As concentrations (up to $4.1 \mathrm{mg} \mathrm{L}^{-1}$ ), are mainly associated with bodies of standing water located on the tailings dams and the stream of tailings extending between them, which are characterized by $\mathrm{pH}$ values between 7 and 11 . Elsewhere the health threat associated with As release into stream and ground waters was perceived to be negligible. MINTEQA2 calculations from water analyses indicated that only the tailings between the two dams approaches $\mathrm{Ca}_{3}\left(\mathrm{AsO}_{4}\right)_{2}$ saturation. A positive correlation between extractable As and total $\mathrm{Ca}$ in soil and sediment samples and the supersaturation of tailings dam water with respect to calcite suggest that As mobility could be linked to sorption by or coprecipitation with calcite, which is consistent with both the calcareous nature of the host rocks and the practice of liming the tailings during ore processing. Arsenic contamination was detected in soils at the base of a waste rock pile despite the fact that the toxicity characteristic leaching procedure (TCLP) showed negligible As removal from two rock samples. Downward leaching of As through the waste rock pile may, therefore, be occurring under the prevailing neutral to alkaline conditions. Red sesquioxidic soil from the mining area was found to have a capacity to immobilize about $3500 \mathrm{mg} \mathrm{kg}^{-1} \mathrm{As}$, suggesting that local soil near Barbrook mine could be valuable as a medium for intercepting arsenical waste. Soil chemical patterns can possibly be linked to Mseleni Joint Disease among rural inhabitants in northern Kwazulu-Natal, South Africa.

\section{The Role of Environmental Geochemistry in the U.S. Geological Survey}

LEAHY, P. Patrick, and McNEAL, James M., U.S. Geological Survey, M.S. 911 National Center, Reston, VA 20192, USA

Environmental geochemistry is a primary component of the mission of the U.S. Geological Survey (USGS) in programmatic activities that provide reliable and impartial information for managing water, biological, energy, and mineral resources, and to enhance and protect the quality of life. These activities include studies of contaminated environments, renewable resources, geochemical environmental models, water availability and quality, environmental effects on human health, and biological resources.
The USGS conducts state-of-the-art research including development and application of the newest technologies in environmental geochemical assessments. All aspects of the geochemical cycle are addressed in conducting these assessments including investigations on the source, transport, and fate of naturally occurring and human-made substances in the environment. USGS also studies past environmental geochemical conditions to improve our understanding of past geochemical processes and the factors affecting the rates of change of these processes. With the recent addition in 1996 of the Biological Resources Division, the USGS also can address very important questions on the ecological effects of these substances.

A diverse range of substances are studied including: (1) trace elements, such as $\mathrm{As}, \mathrm{Pb}, \mathrm{Hg}, \mathrm{Se}$, and $\mathrm{Zn}$; (2) minerals and other natural substances such as pyrite, phosphate, coal, petroleum, and natural gas; and (3) human-made compounds, such as the agricultural nutrient nitrate, the gasoline additive methyl tert-butyl ether, the pesticides used in both agricultural and urban settings, and many industrial compounds including solvents. Detailed, interdisciplinary studies are conducted at specific sites where a number of substances in different settings are investigated. Some of these sites include South Florida, Summitville, Colorado, the Norman landfill in Oklahoma, and Boston Harbor and Massachusetts Bay.

As human population and economic growth continues to increase the stress on the environment, the need for more environmental geochemistry information from the USGS to support decisions by resource managers will expand. With an increasing emphasis in the USGS on multidisciplinary studies and assessments, improving analytical and field technologies, and understanding geochemical and biogeochemical processes and cycles, the value of USGS environmental geochemistry information is also expected to grow.

\section{Incidental Amendment of Mercury to} Agricultural Fields by Turbid Irrigation
Waters and Natural Floods in Nevada and
Oregon

LECHLER, Paul J. and DESILETS, Mario $O$. Nevada Bureau of Mines and Geology, MS 178, University of Nevada, Reno, Nevada 89557, USA

Because of the relative ease of locating mineral deposits in alpine areas, and the fertility and availability of irrigation waters in lowland areas, alpine mining-lowland agriculture (AM-LA) has been commonly developed in the American West. This makes for a relatively common setting of AMLA, and provides for maximum environmental impact from mining-related metal pollution. Two important examples of AM-LA are the Comstock mining district/Carson River/ Lahontan Reservoir/Fallon agricultural area in Nevada, and (2) the Silver City-Delamar mining district/Jordan Creek/ Antelope Reservoir/Jordan Valley agricultural area in Idaho and Oregon. 
Water from these mercury-polluted fluvial systems is used to irrigate fields in the lowland agricultural areas and, because mercury partitions strongly to fine, suspended sediments in fluvial systems, turbid waters applied to these slds incidentally amend the fields with mercuriferous muds, year after year. The very fine sediments which are carried in suspension by rivers for long distances contain higher mercury concentrations than bulk bedload sediments in the active channel. Distal overbank muds deposited during natural flooding also contain much higher mercury concentrations than active channel sediments. Reservoirs capture much of the low- mercury sand and silt carried by the streams but the very fine muds and colloidal material often remain suspended and are deposited on floodplain fields. Unless there are natural or anthropogenic processes which function to remove mercury from these fields, mercury concentrations in these agricultural soils can be expected to increase every year.

Fine, distal overbank muds deposited during the January, 1997 flooding on the Carson River contain very high total mercury concentrations and are illustrative of this process whereby nature and man deposit only the mostcontaminated sediments to these agricultural soils.

\section{Geoenvironmental Assessment of Montana-Potential for Acidic, Metal-Rich Drainage}

LEE, Gregory $K$.

U.S. Geological Survey, M.S. 973, Denver Federal Center, Denver, CO 80225, USA

The U.S. Geological Survey Mineral Resource Surveys Program has been studying the relative potential for acidic, metal-rich drainage in the State of Montana. Collaborators include H. Alminas, V. Bankey, J. Elliott, D. Frishman, D. Knepper, D. Kulik, G. Lee, S. Marsh, A. McCafferty, J. Phillips, J. Pitkin, S. Smith, R. Tysdal, and B. Van Gosen. This effort has relied heavily on geographic information systems (GIS) technologies to not only assemble and query a substantial variety of multidisciplinary information, but also to statistically and empirically examine relationships among these data and produce models illustrating the associations. Digital information sources included U.S. Geological Survey (Geologic, Water Resources, and National Mapping Divisions), U.S. Bureau of Mines, Montana State Bureau of Mines and Geology, Montana State Library, U.S. Forest Service, Environmental Protection Agency, and Oregon State University.

The general model-building approach has been to calculate the significance of spatial association of different levels of the various data layers with respect to "prototype" areas within the state and to then combine the correlative layers according to weights which reflect the levels of significance. To formulate the prototype, that is, to identify areas within the state which typify the situation to be modeled, mining areas considered to be relatively high in acid and metal generating potential and relatively low in acid buffering capacity were selected. Various data layers, including multi-element geochemistry, geology, magnetometry, gravimetry, radiometry, remote sensing, and water $\mathrm{pH}$, were considered as "candidates" to be incorporated as constituents of a model depicting relative favorability of acidic, metal-rich drainage within the state. Using GIS (Erdas IMAGINE) methods, the qualifications of the candidate layers were measured on the basis of the ratio of the percent of the prototype occupied by the candidate to the percent of the state occupied by the candidate. The ratio values were used to determine not only which levels of what layers should be included as constituents in the overall model, but also what weights should appropriately be assigned to these components; thus, weighted "submodels" were produced from the input data. GIS techniques were used to combine the submodels to formulate a composite model, and various methods have been applied in this study. The color-coded composite model image was draped over shaded topographic relief imagery to provide spatial reference.

\section{Dispersion and Enrichment of Potentially Toxic Elements in Areas Underlain by Black Shales and Slates in Korea}

\author{
LEE, Jin-Soo', CHON, Hyo-Taek', and KIM, Kyoung-Woong ${ }^{2}$ \\ 'Department of Mineral and Petroleum Engineering, College of \\ Engineering, Seoul National University, Seoul 151-742 Korea \\ ${ }^{2}$ Department of Earth Resources and Environmental Engineering, \\ Paichai University, Taejon 302-735, Korea
}

The Okchon black shale in Korea provides a typical example of natural geological materials enriched with potentially toxic elements. The Chung-Joo, the Duk-Pyung, the Geum$\mathrm{K}$ wan, the I-Won, the Bo-Eun and the Chu-Bu areas are underlain by these black shales and slates of the Guryongsan Formation or the Changri Formation of Cambro-Ordovician age. These formations are part of the Okchon Group which is found in the central part of Korea. To investigate the level of enrichment and dispersion patterns of potentially toxic elements in rocks and soils, geochemical surveys were undertaken in the above six study areas in the Okchon Zone. After appropriate preparation, rock and soil samples were analyzed by Instrumental Neutron Activation Analysis (INAA) and Inductively Coupled Plasma Atomic Emission Spectrometry (ICP-AES). In particular, As, Ba, Cd, Mo, V, $\mathrm{U}$ and $\mathrm{Zn}$ are highly enriched in the areas underlain by the Okchon black shale, and their mean concentrations are significantly higher than those in the areas covered with black slate. These elements are geochemically associated, and may be enriched simultaneously. The highest mean concentrations of $42 \mathrm{mg} \mathrm{kg}^{-1} \mathrm{As}, 2100 \mathrm{mg} \mathrm{kg}^{-1} \mathrm{Ba}, 11 \mathrm{mg}$ $\mathrm{kg}^{-1} \mathrm{Cd}, 213 \mathrm{mg} \mathrm{kg}^{-1} \mathrm{Mo}, 83 \mathrm{mg} \mathrm{kg}^{-1} \mathrm{U}, 938 \mathrm{mg} \mathrm{kg}^{-1} \mathrm{~V}$ and $394 \mathrm{mg} \mathrm{kg}^{-1} \mathrm{Zn}$ are found in black shales in the Duk-Pyung area. Mean concentrations of $A s, M o$ and $U$ in soils derived from black shales occurring in the Duk-Pyung area $(30 \mathrm{mg}$ $\mathrm{kg}^{-1}$ As, $34 \mathrm{mg} \mathrm{kg}^{-1} \mathrm{Mo}$ and $78 \mathrm{mg} \mathrm{kg}^{-1} \mathrm{U}$ ) and the Chu-Bu 
area (40 mg kg-1 As, $15 \mathrm{mg} \mathrm{kg}^{-1}$ Mo and $29 \mathrm{mg} \mathrm{kg}^{-1} \mathrm{U}$ ) are higher than the permissible level suggested by Kloke (1979), and the enrichment index decreases in the order of DukPyung $>$ Chu-Bu $>$ Bo-Eun $>$ Chung-Joo $>$ Geum-Kwan $=\mathrm{I}$ Won areas. Uranium-bearing minerals such as uraninite and brannerite have been identified in black shales from the Chung-Joo area by Electron Probe Micro Analysis. Uraninite grains of $2 \mu \mathrm{m}-10 \mu \mathrm{m}$ size are closely associated with monazite and pyrite, whereas brannerite grains occur as an euhedral form of $50 \mu \mathrm{m}$ diameter.

\section{NEOCHIM - An Electrogeochemical Method for Environınental Applications}

\author{
LEINZ, Reinhard W., WILSON, Stephen A., and HOOVER, \\ Donald B. \\ U.S. Geological Survey, Denver Federal Center, P.O. Box 25046, \\ MS 973, Denver, CO 80225-0046, USA
}

NEOCHIM is a U.S. Geological Survey modification of Russian electrogeochemical technology developed for mineral exploration, which we believe has relevance to environmental investigations. The method is based on the migration of ions from the earth into specially designed electrodes by means of an applied electrical field. The earth constitutes part of an electrolytic cell in which desired changes are induced by action of the electric current. Tests have shown advantages of NEOCHIM over conventional geochemical methods in exploration for buried ore deposits. These advantages should benefit environmental investigations concerned with the origin and migration of metals in the vadose zone. Additionally, the technology should be useful for the remediation of soils or waste material associated with the mining and smelting industries. A patent for soil remediation has been applied for based on our NEOCHIM technology.

A major advantage of NEOCHIM over traditional sampling techniques is derived from its ability to sample large volumes of soil. The volume sampled for a specific ion under ideal conditions, can be determined by the relationship $\mathrm{V}=\mathrm{mrQ}$, where $\mathrm{m}$ is the ion mobility, $\mathrm{r}$ is soil resistivity, and $Q$ is the electrical charge delivered to the electrode. The volume can also be determined knowing the saturation and salinity of the soil and the electrical charge transfer. Besides the ability to extract ions, NEOCHIM can be used to introduce selected ions to bring about desired chemical changes in the soil. Treatment volume is controlled by electrode placement and charge transfer, but is essentially unrestricted. Experiments were conducted to compare actual volumes affected by NEOCHIM and other electrochemical methods with predicted volumes for various types of soil. The results show the practicality of using NEOCHIM technology for monitoring and remediation purposes.
Geochemistry of Arsenic and Fluorine in Shallow Ground Water: Eastern Owens Lake, California

LEVY, David B., SCHRAMKE, Janet A., ESPOSITO, Kenneth J., ERICKSON, Tyler A, and MOORE, J.C.

Shepherd Miller Inc., 3801 Automation Way, Suite 100, Fort Collins, CO 80525, USA

Recurrent dust storms at Owens (dry) Lake in southeastern California present human health hazards from the small particle sizes and elevated trace element concentrations of suspended surface salts. This study was conducted to examine the evolution of As and F in shallow, upwardflowing ground waters at the eastern margin of Owens Lake. Ground waters were analyzed for $\mathrm{pH}$, conductivity, As, F, and major elements. Lakebed sediments and surface salts were analyzed for total element concentrations and mineralogical composition, and the potential for natural release of As and $\mathrm{F}$ from the solids was evaluated using the Meteoric Water Mobility Procedure (MWMP). Mineral saturation indices were calculated using the computer code PHRQPITZ, and solution speciation of As and F was calculated using EQ3NR. Evapoconcentration of shallow ground waters produces high $\mathrm{pH}$, high alkalinity brines whose major ion compositions are consistent with those predicted by the Hardie-Eugster Model. Evaporite minerals identified in the surface salts were halite $(\mathrm{NaCl})$, thenardite $\left(\mathrm{Na}_{2} \mathrm{SO}_{4}\right)$, trona $\left[\mathrm{Na}_{3} \mathrm{H}\left(\mathrm{CO}_{3}\right)_{2} \cdot 2 \mathrm{H}_{2} \mathrm{O}\right]$, pirssonite $\left[\mathrm{Na}_{2} \mathrm{Ca}\left(\mathrm{CO}_{3}\right)_{2} \cdot 2 \mathrm{H}_{2} \mathrm{O}\right]$, and nesquehonite $\left(\mathrm{MgCO}_{3} \cdot 3 \mathrm{H}_{2} \mathrm{O}\right)$. Significant correlations between $\mathrm{As}$ and $\mathrm{F}$ in shallow ground waters and MWMP extracts indicate that As and $F$ are not partitioned into surface salts until very high salinities are reached, and that $A s$ and $F$ can be readily released from lakebed sediments when exposed to rainfall. Conservative behavior of $A$ s and $F$ in the shallow ground waters results from: (1) complexation of $\mathrm{As}$ with $\mathrm{F}$ as $\mathrm{AsO}_{3} \mathrm{~F}^{2-}$ (aq) undersaturation with respect to fluorite $\left[\mathrm{CaF}_{2(\mathrm{~s})}\right]$, and (3) low adsorption affinities of As and $\mathrm{F}$ for mineral surfaces at the high $\mathrm{pH}$ values.

\section{Variable Geochemical Responses to Water- Rock Interactions at Two Undisturbed Zn- Pb Massive Sulfide Deposits, Bathurst Mining Camp, N.B., Canada}

\author{
LEYBOURNE, Matthew I., GOODFELLOW Wayne D., and \\ BOYLE, Dan $R$. \\ Geology Dept., Univ. of Ottawa, Ottawa, Ontario, Canada KIN \\ 6 N5 \\ Geological Survey of Canada, 601 Booth Street, Ottawa, Ontario, \\ Canada KIA OE8
}

A detailed hydrochemical study at two undisturbed Ordovician massive sulfide $(\mathrm{Zn}-\mathrm{Pb})$ deposits (Restigouche and Halfmile Lake) was initiated to determine the processes controlling the oxidation and dissolution of sulfide minerals, 
the subsequent dispersion of metals in ground and surface waters, and the precipitation of secondary minerals. The hydrogeochemical signature is different for the two deposits. Elements that form sulfide minerals in the deposits correlate ,ositively in surface waters and increase with proximity to the Restigouche deposit, whereas, metal contents for the Halfmile Lake deposit are lower, though still typically higher than background levels. Higher $\mathrm{Cl}$ contents in surface waters near the Restigouche deposit reflect the influence of the hydrothermal alteration minerals in the rocks hosting the ore body rather than hydrological connection with deeper saline ground waters. Variations in chemical composition of surface waters draining the two deposits is controlled in part by the depth and geometry of the massive sulfide bodies. Halfmile Lake deposit is deeper, more steeply dipping, and overturned compared to the shallower Restigouche deposit. Ground waters at Halfmile Lake up to $760 \mathrm{~m}$ below surface are low-TDS ( $\left.<200 \mathrm{mg} \mathrm{L}^{-1}\right) \mathrm{Ca}_{-} \mathrm{HCO}_{3}$ waters with oxygen and deuterium isotopic compositions identical to surface waters. Ground-water REE patterns are flat to LREE enriched and are similar to host lithologies, unlike the surface waters which are LREE depleted compared to shale. The Restigouche ground waters range up to $21,000 \mathrm{mg} / \mathrm{L}$ TDS ( $\mathrm{NaCl}$ waters) and display heavier oxygen and deuterium isotopic compositions than local surface waters. Variations in ground-water composition requires that the two deposits have different hydrologies which influence the natural oxidation of the massive sulfides and their effect on the environment.

\section{The Application of Regional Geochemical Data in an Environmental Study}

\section{LI, Shan-Fang, and REN, TianXiang}

Chinese Academy of Geoexploration, 64 Funei Dajie, Beijing. 100812, PR China

Over the past 15 years, abundant data acquired in the second generation, high-quality regional geochemical prospecting of China has been applied to environmental studies, and this paper deals with the remarkable achievements made in this aspect.

In the second generation regional geochemical prospecting, all-round improvement was achieved from choice of methods, sampling arrangement, and analytical technique to data processing and map compilation. Up till now, the work has covered $5,170,000 \mathrm{~km}^{2}$. In an area where regional geochemical prospecting had been carried out, research on applying geochemical data to environmental studies was subsequently conducted. According to the relationship of the growth of crops and fruit trees and the incidences and death rates of various diseases to the geochemical distribution of varied elements and the effective distribution of individual elements, environmental geochemical maps were compiled. The investigation and comparative study conducted in the study area reveal that the somewhat low Mo and $\mathrm{Cr}$ contents might account for the increase in death rate caused by esophagus cancer, hypertension and diabetes. It is also pointed out that high $\mathrm{Cd}, \mathrm{As}$ and $\mathrm{Pb}$ in the upper reaches of a reservoir within the study area might affect the water quality of the reservoir and hence threaten the health of local people. In addition, small-scale geochemical maps covering the whole country were compiled recently on the basis of the second generation geochemical data. It is obvious that these maps will not only prove very useful in regionalization of metallogenic prospects and studies of basic geology, but surely play an important role in such research aspects as environments, endemic diseases, agriculture and animal husbandry as well.

\section{Concentration and Chemical Partitioning of Heavy Metals in Road Dusts and Urban Soils in Hong Kong}

\author{
LI, Xiangdong', POON, Chi-sun', CHAN, Rachael', COLES, \\ Barry J. ${ }^{2}$, RAMSEY, Michael H. $^{2}$, and THORNTON, Iain ${ }^{2}$ \\ 'Environmental Engineering Division, Dept. of Civil \& Structural \\ Engineering, The Hong Kong Polytechnic University Hung Horn, \\ Kowloon, Hong Kong \\ ${ }^{2}$ Environmental Geochemistry Research, Royal School of Mines, \\ Imperial College, London SW7 2BP U.K.
}

The rapid economic development and fast urbanization in Hong Kong over the last three decades have put great pressures on the local environment. Urban soils are subject to many pollution sources within urban areas, for example, traffic emissions and industrial activities. In this study, road dusts and urban soils were collected from selected community parks and public amenity sites in Hong Kong, which represent the high population density areas and areas close to industrial activities.

The samples were analyzed for total metal concentrations and their chemical partitioning among selected geochemical phases. The results show that the street dusts and roadside soils contain elevated concentrations of a number of heavy metals, which reflect the influences from traffic emissions and various industrial operations. The high zinc content in the street dusts may indicate some special anthropogenic inputs, probably from transportation sources. The chemical partitioning results show that lead and zinc are mainly in the adsorbed carbonate and Fe-Mn oxide phases, where copper is largely associated with the organic and sulfide fractions. Most of the nickel is in the residual silicate forms. The environmental mobility and bioavailability of heavy metals in the subtropical urban environment will be discussed. 


\section{Investigation of the Environmental Impact from Industry Wastes Deposited in an Urban Area of Falun, Sweden}

\author{
LIN, Zhixun', HARSBO, Kristina ${ }^{2}$, and AHLGREN, Malin ${ }^{3}$ \\ 'Environmental Geology, Institute of Earth Sciences, Uppsala \\ University, 75236 Uppsala, Sweden \\ ${ }^{2}$ Falun County Board, Environmental Unit, 79183 Falun, Sweden \\ ${ }^{3}$ Institute of Environmental and Developmental Biology, Uppsala \\ University, 75236 Uppsala, Sweden
}

Historically, the city of Falun in the province of Dalarna, Sweden was a center for $\mathrm{Cu}$ mining, sulfuric acid manufacturing and paint pigment production. The mining and chemical industries have generated vast amounts of wastes which have been deposited around the area since the mid 1800 's. Now a large part of the city is built on the wastes. During the last two decades, great amounts of work on waste management have been completed. Previous investigations showed that the soils of the urban areas have been contaminated by wastes with rather high levels of $\mathrm{Pb}$. What is the speciation of soil $\mathrm{Pb}$, and how does the $\mathrm{Pb}$ reach the biosphere? How can the contamination best be isolated? Our study is aimed at a better understanding of these environmental problems by investigating the distribution of $\mathrm{Pb}$ in the urban soils by means of chemical and mineralogical methods, and by investigating the quantity and quality of the fallout particles, as well as tracing the potential source of contamination. The chemical extraction and mineralogical analysis indicates that $\mathrm{Pb}$ speciation may be mainly associated with some stable mineral phases, for example, iron oxide and sulfide phases occurring in the urban soils. Because of the $\mathrm{Pb}$-bearing phase characteristics, the high level soil $\mathrm{Pb}$ in the urban area seems not to be directly related to the blood- $\mathrm{Pb}$ in children. Lead and $\mathrm{As}$ are usually associated with iron in forms of $\mathrm{Pb}$-bearing and $\mathrm{As}$-bearing particles in the fallout which has been collected from three stations in the urban area for one year. It is suggested that the oxidation of sulfide minerals at the surface of the sulfiderich industry wastes leads to retention of $\mathrm{Pb}$ and $\mathrm{As}$ in iron oxides through coprecipitation and/or adsorption. Subsequently these fine grained, $\mathrm{Pb}$ and $\mathrm{As}$ bearing, iron oxides are distributed by wind over short distances.

\section{In-Situ Alteration of Minerals by Acidic Ground Water Resulting from Mining}

\section{Activities}

\author{
LIND, C.J.' and ANGEROTH, Cory ${ }^{2}$ \\ 'USGS, 345 Middlefield Rd., Menlo Park, CA 94025 \\ ${ }^{2}$ USGS, WRD District Office, 520 N. Park Ave., Suite 221, Tucson, \\ AZ 857 I9
}

Ground water in the Pinal Creek Basin, Arizona has reached a $\mathrm{pH}$ of -3.6 as a result of copper mining activities. While traversing the $10 \mathrm{~km}$ distance from the site where the ground water is highly acidic to where it rises to the surface, interaction with alluvial material in the ground water flow path alters the $\mathrm{pH}$ to nearly neutral.

Geochemical reactions affecting ground- and surfacewater evolution have been studied and modeled on basis of data from the analyses of these waters and especially data concerning ground-water and core composition in monitoring wells in the transition zone between highly acidic ground water and near-neutral ground water.

In-situ experiments were carried out in these transitionzone wells to determine: (1) the reaction rates for some of the neutralization (carbonate reactions) and redox ( $\mathrm{Mn}-\mathrm{Fe}$ redox reactions) processes, and (2) more details concerning the characterization of the actual reaction processes. A series of polypropylene mesh bags was located at the screen level. Each bag contained an inner mesh bag of test mineral imbedded in core material from the level of the well screen. The test minerals chosen are based on composition of the core material and the reaction to be tested. A sample bag from a series of bags in each well is removed for examination just prior to the routine bimonthly sampling for groundwater analysis.

\section{Comparison of the Measured and Modeled Geochemical Composition of a Nevada Pit Lake}

LOCKE, William W., ATKINS, David A., KEMPTON, J. Houston, MCDONALD, Richard R., and BLISS, Linda N.

PTI Environmental Services, 4940 Pearl East Circle, Suite 300, Boulder CO 80301, USA

Seventeen pit lakes have formed from open-pit mines in Nevada, with nineteen more anticipated as a result of current or proposed projects. While predictions of pit lake water quality are required for mine permitting, no comparisons of model results with observed geochemical conditions in pit lakes have been available previously. A comparison of measured and modeled limnologic and geochemical conditions was undertaken for a lake currently forming at a Nevada gold mine. The lake has a maximum depth of $26 \mathrm{~m}$ and is a low-productivity, meromictic lake with a chemocline at a depth of $15 \mathrm{~m}$. The monimolimnion is anoxic yearround, while the mixolimnion is seasonally stratified. Limnologic conditions were replicated using the U.S. Army Corps of Engineers hydrodynamic and water quality model CE-QUAL-W2. Geochemical conditions were simulated using a predictive numerical model of pit-lake geochemistry developed by the authors. The geochemical model assumes that major sources of chemical loading are solutes in inflowing ground water and flushing of sulfide oxidation products released from exposed wall rock, with minor additional loading from surface runoff and blast residue. Solute removal mechanisms include mineral precipitation, coprecipitation, and adsorption to iron oxides. Model parameters include water balance, wall-rock surface area and sulfide content, sulfide oxidation, wall-rock leachate composition, ground-water composition, and equilibrium 
precipitation and adsorption. Model results are presented and compared with analytical measurements of lake chemistry for a broad suite of analytes.

\section{Natural Analogue for Bedrock Pollution: Environmental Impact of Ni-Cu-Zn-Rich Black Shales at Talvivaara in Finland}

\author{
LOUKOLA-RUSKEENIEMI, Kirsti', UUTELA, Anneli ${ }^{2}$, \\ TENHOLA, Markku', and PAUKOLA, Tarja' \\ ${ }^{\prime}$ Geological Survey of Finland, P.O. Box 96, 02151 Espoo, \\ Finland \\ ${ }^{2}$ Department of Geology, 01400 University of Helsinki, Finland \\ ${ }^{3}$ Geological Survey of Finland, P.O. Box 1237, 70211 Kuopio, \\ Finland
}

To assess the influence of variations in bedrock composition on water and sediment geochemistry in pristine catchment areas, chemical data and $\mathrm{pH}$ measurements were obtained from surface and ground waters and organic stream sediments in the vicinity of the Talvivaara black shale-hosted Ni$\mathrm{Cu}-\mathrm{Zn}$ occurrence. In addition, lake sediment profiles were drilled in seven lakes for the purpose of studying changes in chemical composition since the termination of the last Ice Age. Surface and ground waters (except for springs) and stream sediments in areas underlain by black shales are all characterized by elevated $\mathrm{Ni}, \mathrm{Cu}, \mathrm{Zn}$, and $\mathrm{Cd}$ abundances with respect to median values for Finland as a whole, as well $s$ in comparison with adjoining areas underlain by granitic and quartzitic bedrock. Sediments from lakes overlying black shales record exceptionally acidic intervals immediately after draining of the Sotkamo ice lake ( $\mathrm{pH} 3.8$ ). Present day $\mathrm{Al}, \mathrm{Zn}, \mathrm{Cu}$, and $\mathrm{Ni}$ abundances are still higher than in lakes outside the black shale area, but differences are no longer so marked, largely due to mitigating effects of a dense cover of vegetation.

When evaluating the potential environmental impact of mining and processing in a given area it is necessary to establish natural variations in element abundances. In the Talvivaara area for example, certain elements display baseline abundances greatly in excess of those elsewhere in Finland. Moreover, some areas may be more susceptible than others or respond in different ways to human interference. Wells drilled in areas underlain by metalliferous black shales do not provide water of good quality. Forestry and other activities should be managed carefully so as to avoid exposure of bedrock, given the typically low background $\mathrm{pH}$ values of surface waters in such areas.

\section{Uses of Chemical Speciation for Impact Evaluation and Remediation of Mining Waste}

\author{
LUND, D., FARAGO, M., and THORNTON, I. \\ Environmental Geochemistry Research Group, Centre for \\ Environmental Technology, Imperial College of Science \\ Technology and Medicine, London SW7 2BP, UK
}

Mineral and other chemical species associated with metal mining waste can lead to a wide range of potential physical, social and economic impacts, both of the waste dump and through migration to other sites. Regulations for the control and remediation of mine waste are based on the measurement of total metal concentrations without consideration of the likely current and future potentials for leaching or bioavailability.

High levels of As and $\mathrm{Cu}$ occur in the South West of Britain associated with historic mining activities and naturally occurring high background levels of contamination. Samples were obtained from Poldice (Redruth, Cornwall), Devon Great Consols (Gunnislake, Devon) mine sites and historic sulfidic As-Cu mines near Seville (Spain) for speciation studies. The samples were analyzed using SEM to give information on mineral forms and presence of weathering rinds of potentially differing mobilities. They were also analyzed using a modified Tessier sequential extraction sequential extraction scheme, the simplified scheme currently being tested by the Measurement and Testing Programme (formerly the BCR) of the Commission of the European Communities and a scheme modified to indicate As availability. Samples were then analyzed using ICPAAS. These analyses gave data on total metal concentration, mineral species occurring, some factors affecting secondary mineral formation, and likely present and future bioavailability and mobility of the samples.

Speciation analysis has economic implications using cost benefit evaluation to prioritize sites most urgently requiring remediation. More appropriate long-term management strategies can also be developed for individual sites. The data indicating likely mobility and availability could have input into the formation of contaminated land regulations to better reflect true risks to health.

\section{Regression Methods in Bedrock Ground- Water Composition Estimation from Hydrogeological Parameters}

\author{
LUUKKONEN, A., KORKEALAAKSO, J. and PITKÄNEN, P. \\ VTT Communities and Infrastructure, Rock and Environmental \\ Engineering, P.O. Box 1904I, 02044 VTT FINLAND
}

Methods for ground-water composition estimation are developed, when a group of hydrogeological variables are known. The input variables used are related to the host type of ground water, hydrological conditions in the host, mixing potentials between different types of ground water, and 
minerals equilibrated with ground water. The example output variables are electrical conductivity, $\mathrm{Ca}, \mathrm{Sr}, \mathrm{Mn}, \mathrm{Na}$, $\mathrm{Cl}, \mathrm{HS}, \mathrm{SO}_{4}$, alkalinity, ${ }^{3} \mathrm{H}$ and ${ }^{14} \mathrm{C}$ concentrations, and $\mathrm{pH}$ in the ground water.

The methodology is to associate the known hydrogeological conditions (input variables), to the known water compositions (output variables), and to evaluate mathematical relations between these groups. Output estimations are done with two separate procedures: by making a partial least square regression to principal components of input variables, and by training radial basis function neural networks with input-output pairs. The coefficients of linear equations and trained networks are optional methods for actual predictions. The quality of output predictions are monitored with confidence limit estimations, evaluated from input variable covariances and output variances, and with charge balance calculations.

Romuvaara is one of the study areas of detailed nuclear repository site investigations in Finland. Ground-water compositions in the Romuvaara borehole KR10 are predicted with 10 meter intervals. The predictions are done with actual host type and hydraulic conductivity information available in autumn 1996.

The two prediction methods are compared to each other, and advantages and drawbacks of the methods are pointed out. Ultimately, the methodology is aimed for modeling composition fluctuations of ground water in $3 \mathrm{D}$, in the situations where an extensive hydrogeological knowledge and a irregular network of hydrogeological and geochemical point data are available.

\section{The Connection of Some Heavy Metals With a Magnetic Phase in Fly Ashes from Two Polish Thermal Power Plants}

\author{
MAGIERA, Tadeusz and STRZYSZCZ, Zygmunt \\ Institute of Environmental Engineering, Polish Academy of \\ Sciences, ul. Sklodowskiej-Curie 34, 41-800 Zabrze, Poland.
}

Pyrite is one of the most important coal minerals since it is a major source of $\mathrm{S}$ and $\mathrm{Fe}$ in many coals. Other elements of environmental concern, such as $\mathrm{Ni}, \mathrm{Cd}, \mathrm{Cu}, \mathrm{Cr}, \mathrm{Zn}$ and $\mathrm{Pb}$ are often associated with pyrite as well. The fly ashes coming from fossil fuel combustion contain a considerable amount of magnetic particles which are the result of sulfide (mostly pyrite) oxidation during combustion processes. The magnetic spinel phase is enriched in many trace elements, particularly first-row transition metals (V, Cr, Mn, Co, Ni, $\mathrm{Cd}, \mathrm{Zn}, \mathrm{Cu}$ ). The presence of magnetic particles in fly ashes can be easily detected by a measurement of magnetic susceptibility (c) value. The $c$ value of fly ashes after hard coal combustion is a rather high range from 1,400 to 3,400 $\mathrm{X} 10^{-8} \mathrm{~m}^{3} \mathrm{~kg}^{-1}$. Seven most common heavy metals $(\mathrm{Cr}, \mathrm{Mn}$, $\mathrm{Ni}, \mathrm{Cu}, \mathrm{Zn}, \mathrm{Cd}, \mathrm{Pb}$ ) have been determined in bulk material and in magnetic concentrate made from fly ashes of two polish power plants (Jaworzno III and Siersza). Eleven magnetic particles have been studied using the microprobe.
It was found that $\mathrm{Pb}, \mathrm{Ni}, \mathrm{Zn}$, And $\mathrm{Cu}$ occur in substantial quantities in some of the 11 particles. Geochemical studies exhibit a considerable correlation between the $c$ value and concentration of some heavy metals which are connected with the magnetic phase of fly ashes (in many cases the correlation coefficient is over 0.7 ). The extraction studies suggest that the amount of extractable elements depends on fraction and $\mathrm{pH}$. Some of the elements are relatively easily mobilized and they are probably connected with the magnetic particles by surface adsorption. Some part of such elements $\mathrm{As} \mathrm{Cr}, \mathrm{Mn}, \mathrm{Co}, \mathrm{Ni} A$ nd $\mathrm{Zn}$ are probably in the form of substituted spinels, $\mathrm{Fe}_{3-\mathrm{x}} \mathrm{M}_{\mathrm{x}} \mathrm{O}_{4}$. The results of this study suggest that magnetic susceptibility measurements can give some information about a potential threaten with some trace elements.

\section{Ground Truth Versus GIS Model-The Ground-Water Quality of the Vistula River Floodplain near the City Of Plock (Poland)}

\section{MAGNUSZEWSKI, Artur \\ Warsaw University, Krakowskie Przedmiescie 30, 00-927, Warszawa, Poland}

Maps of the vulnerability of ground water to contamination obtained by GIS modeling are used often for spatial planning, water management, and environmental protection. The advantage of GIS modeling and presentation is a multivariable and spatial approach which corresponds to the fundamental properties of the natural environment (complexity and continuity). The simplified version of the DRASTIC model (developed by U.S. EPA) linked with a GIS program (ILWIS) has been applied to the studies of ground-water quality of the Vistula River floodplain near the city of Plock in central Poland. The ground water of the floodplain is highly polluted due to the: lowest location of the aquifer in the surrounding landscape, bank infiltration of the river water, shallow water table not protected from infiltration, and extensive agriculture. Digital maps of the soil texture, ground-water depth, land use, and terrain model (DTM) have been created. Obtained modeling results have been verified by fieldwork sampling and analyzing water quality $\left(\mathrm{NH}_{4}, \mathrm{NO}_{3}, \mathrm{NO}_{2}\right.$, total hardness). The results of the modeling show the projected conditions of the ground-water contamination, while fieldwork provides a measurement of the actual situation. The model accurately projected the total hardness distribution, and low hardness corresponds to the high pollution vulnerability areas, which are also the ground-water recharge areas. The nitrate contamination is very difficult to interpret because it is linked with the local pollution sources, which are not addressed in the model. Conceptual models like DRASTIC are appropriate for shallow ground-water contamination surveying, combined with fieldwork verification.

This paper is a result of German-Polish cooperation within the IHP IV UNESCO project "Floodplain pollution control-management". 


\section{Pollution of Czech Freshwaters by Trace Elements}

\author{
MAJER, Vladimír and VESELÝ, Josef \\ Czech Geological Survey, 11821 Prague 1, Czech Republic
}

Pollution of freshwaters and river sediments by trace elements were investigated on the territory of the Czech Republic. Samples of river sediments $(\mathbf{n}=298)$ were analyzed for up to 65 elements using AAS, XRA and NAA; samples of surface waters $(n \sim 14,000)$ were analyzed by GAAS, FAAS and HPLC.

A majority of Czech rivers is polluted by $\mathrm{Ag}, \mathrm{As}, \mathrm{Au}$, $\mathrm{Bi}, \mathrm{Cd}, \mathrm{Cu}, \mathrm{Hg}, \mathrm{P}, \mathrm{Pb}, \mathrm{Sb}, \mathrm{Se}$ and $\mathrm{Zn}$, whose median concentrations are more than twice the average concentrations of these elements in shales. Some rivers were strongly polluted also by $\mathrm{U}, \mathrm{Sn}, \mathrm{Be}$ and $\mathrm{Cr}$. Pollution of rivers results from discharge of industrial waste waters and historic mining activity. Concentrations of $\mathrm{Be}, \mathrm{Cd}, \mathrm{Zn}$ and $\mathrm{Mn}$ are higher in freshwater streams acidified by long-range transport of $S$ and $\mathrm{N}$ compounds. High concentrations of As were observed in freshwaters in the vicinity of brown coal-burning power stations and in regions where oxidation of arsenopyrite occurs. Variability of trace element content was investigated by principal factor analysis. Variability of $\mathrm{Sr}$ and $\mathrm{F}$ in waters depends on bedrock and ground-water influence; $\mathrm{pH}$ value affects concentrations of $\mathrm{Be}, \mathrm{Cd}, \mathrm{Zn}$ and $\mathrm{Mn}$; sorption on Fe-oxyhydroxides affects concentrations of $\mathrm{Pb}, \mathrm{Cu}, \mathrm{Zn}$, $\mathrm{F}_{\mathrm{e}}$ and $\mathrm{Cd}$. In river sediments, heavy metals $(\mathrm{Zn}, \mathrm{Pb}, \mathrm{Cd}$, $\mathrm{Ag}, \mathrm{Cu}, \mathrm{Sb}, \mathrm{Bi}$ ) are mostly bound as sulfides, while variability of rare-earth elements $\mathrm{Th}, \mathrm{Y}, \mathrm{Zr}, \mathrm{Hf}, \mathrm{Nb}$, and Ta depends on the presence of heavy minerals (monazite, zircon and titanite). The results of principal factor analysis, maps of concentrations of selected trace elements both in freshwater and river sediments will be presented. The history of pollution will be demonstrated through changes of metal concentrations in lake and overbank sediments with time.

\section{The Investigation of Redox Reactions and Adsorption of Chromium in Soils}

\author{
MAKINO, T., HATTA, T., KAMEWADA, K., TAKAHASHI, Y., and \\ SAKURAI, Y. \\ National Institute of Agro-Environmental Sciences, Tsukuba, \\ Ibaraki, Japan
}

The oxidation of $\mathrm{Cr}$ (III) to $\mathrm{Cr}(\mathrm{VI})$ presents a significant environmental hazard due to the much greater mobility and toxicity of $\mathrm{Cr}(\mathrm{VI})$. It is important to know the dynamics of chromium in soils, especially oxidation and adsorption.

Therefore, the abiotic oxidation and adsorption of chromium added to soils were investigated using different kinds of soils including andisols, entisols and inceptisols.

Adsorption form of $\mathrm{Cr}$ (III) added to soils was analyzed by selective dissolution methods. $\mathrm{Cr}$ (III) was mainly adsorbed onto soils as the acid-soluble and organically bound form. $\mathrm{Cr}$ (VI) was effectively adsorbed to andisols, which was attributed to abundance of non-crystalline iron oxides and aluminum oxides such as ferrihydrite and allophane, respectively.

The amount of $\mathrm{Cr}$ (VI) in equilibrium in solution converted from $\mathrm{Cr}$ (III) added to soils was correlated with manganese content in soils other than andisols, and manganese dissolution was observed during $\mathrm{Cr}$ oxidation. According to the results calculated from the Gibbs free energy of $\mathrm{Mn}, \mathrm{Fe}$ and $\mathrm{Cr}, \mathrm{Cr}$ oxidation can be caused by the reduction of manganese oxides, but not by that of iron oxides. Manganese oxides in andisols are in a relatively low state of oxidation compared to those in soils which show a high level of $\mathrm{Cr}$ oxidation. The oxidation of $\mathrm{Cr}$ (III) was strongly suppressed by the presence of phosphoric acid but not suppressed by sulfonic acid. Furthermore, the adsorbed $\mathrm{Cr}$ (III) on andisols was detected by using ESCA, when $\mathrm{Cr}$ (VI) was added to andisols. These data indicate that reduction and adsorption of $\mathrm{Cr}$ was simultaneously caused in andisols.

\section{Methods of Monitoring of Environmental Health-With Special Reference to Regions in Ecological Crisis}

MALKHAZOVA, Svetlana M. and KOROLOVA, E. G. Faculty of Geography, Moscow State University, Russia

The threat posed to public health by industrial activities is a major concern in the Russian Federation and it is of particular interest to attempt to establish the nature of the relationship between environmental hazards and incidences of health problems.

Air pollution from Astrakhan's gas-condensation plant causes negative changes in the environment of Lower Volga and human health problems in the area are serious.

Certain methods have been used to study these relationships between environment and health in what is a simplified situation, characterized by localized but highly contaminating sources of pollution. The emissions of toxic substances (e.g., $5,000 \mathrm{~kg}$ of sulfur compounds $\mathrm{a}^{-1} \mathrm{~km}^{-2}$ ) cause the decrease of soil $\mathrm{pH}$ from 8.5 to 7.5 and lower, which is reflected in the mobilization of heavy metals present in soil. Ecological toxicological research of animals has shown that at plots with heavy air pollution animals accumulate a number of toxicants (heavy metals) in their bodies. These outcomes may be extrapolated for people. The second approach is based upon data of medical statistics and includes mapping of human health by means of the automatic system "AKS-MSU". Analysis of population diseases near Astrakhan's gas plant shows deterioration in a number of characteristics, mainly in the amount of acute children's respiratory infections and cardiovascular and nervous diseases. One more method is based on the data of the medical sociological questionnaire "Your health". It helped to get important additional information about the effect of hazardous materials of gas work on human health. 


\section{Mapping Chemical Contaminants in} Estuarine and Coastal Marine Sediments: New Approaches to Validating and Using Historical Data

\section{MANHEIM, Frank T. and BUCHHOLTZ TEN BRINK, Marilyn U.S. Geological Survey, Coastal and Marine Geological Center, Woods Hole MA 02543}

Since the early 1990's, a USGS team, working in cooperation with local and federal agencies, has attempted to recover as much historical data as possible pertaining to the highly-contaminated sediments from Boston Harbor and adjacent areas of Massachusetts Bay. This study has two objectives: to complement sediment coring and sediment particulate sampling studies that are conducted cooperatively with the Massachusetts Water Resources Authority, and to explore new approaches to historical data rescue. We assembled data from about 2,500 samples from many dozens of reports from "gray literature". About 500 samples were from USGS field work and aided the evaluation of the more heterogeneous historical data.

Steps that aided in preparing a validated database from heterogeneous data included: (1) sharing of tasks and products with other agencies, including U.S. EPA, Region I, and the U.S. Army Corps of Engineers, (2) use of standard desktop database management and spreadsheet software rather than SQL-based relational database software, (3) use of batch screening techniques to identify gaps and questionable data, rather than application of $\mathrm{QA} / \mathrm{QC}$ protocols to individual samples, and (4) utilizing quality-controlled comparison samples. Once clerical and other errors were identified and corrected, as few as $5 \%$ of the $\mathrm{Zn}$ and $\mathrm{Cu}$ analyses were found to be questionable.

Between 40 and $60 \%$ of the samples from Boston Harbor area contained metal concentrations linked to acute toxicity effects in benthic organisms, based on current national bulk-sediment screening criteria for $\mathrm{Zn}, \mathrm{Cu}, \mathrm{Pb}, \mathrm{Cr}$, and $\mathrm{Hg}$. Although the areal variability of metal concentrations was great, especially where impacted by consolidated sewer overflows, the central Boston Harbor area showed significant statistical decreases in concentration with time in surface samples taken over the past 20 years. We conclude that compilation of historical sediment chemical data can greatly increase knowledge of spatial and temporal distribution of contaminants in sediments from coastal waterways.

\section{On Determination of Heavy Metal Fractions in Estuarine Sediments}

MARGOLINA, Sofia E. and SADOVNIKOVA, Ludmila K. Soil Science Department, MSU, Vorobievy Gory, 119899 Moscow, Russia

A great part of anthropogenic heavy metals released into the river flows precipitates within the estuarine zones and accumulates in estuarine sediments in different forms.
Therefore, developing rapid methods for determination of different metal fractions for such objects is quite essential for indication of present and potential pollution in the aquatic environments. Within the present work an attempt has been made to separate three ecologically significant fractions of heavy metals in estuarine sediments by means of three common soil extractants.

Surface sediment samples collected during a scientific cruise in 1995 within the INTAS project 94-391 in five estuaries of Western Russian Arctic (Keret, Northern Dwina, Mezen, Pechora, Khaipudir) were exposed to a successive extraction. The extraction sequence was as follows: 1M $\mathrm{NH}_{4} \mathrm{NO}_{3}>0.1 \mathrm{M} \mathrm{Na}_{4} \mathrm{P}_{2} \mathrm{O}_{7}>1: 1 \mathrm{HNO}_{3}$ (heating). It was assumed that exchangeable, organically bound and mineral incorporated metals, respectively, were obtained in the extracts. Contents of $\mathrm{Fe}, \mathrm{Mn}, \mathrm{Cu}, \mathrm{Zn}, \mathrm{Ni}, \mathrm{Cr}, \mathrm{Co}, \mathrm{Pb}$ and $\mathrm{Cd}$ in the extracts were determined by atomic absorption spectroscopy. The summation of three fractions was considered as a measure of total element content of the sample. The amounts of $\mathrm{Cd}$ were found below the detection limit in the samples.

$1 \mathrm{M} \mathrm{NH}_{4} \mathrm{NO}_{3}$ was found too weak as an extractant for heavy metals in estuarine sediments, since released amounts of $\mathrm{Fe}, \mathrm{Cu}, \mathrm{Ni}, \mathrm{Cr}, \mathrm{Co}$ and $\mathrm{Pb}$ were too low for precise determination in all the extracts. Traces of exchangeable $\mathrm{Zn}$ were found, but this fraction makes up an average $1-10 \%$ of the total contents for $\mathrm{Mn}$, which is more sensitive to redox conditions and more subjected to migration processes and, thus, can be more easily removed from the sediments by neutral solution.

$0.1 \mathrm{M} \mathrm{Na}_{4} \mathrm{P}_{2} \mathrm{O}_{7}$ releases only negligible amounts of $\mathrm{Ni}$, $\mathrm{Cr}$, and $\mathrm{Pb}$, but it dissolves $5-8 \%$ of the total contents for $\mathrm{Fe}$, 3-30\% for $\mathrm{Mn}, 10-45 \%$ for $\mathrm{Cu}$ and $15-40 \%$ for $\mathrm{Zn}$. The relatively low contents of organically bound metal fraction in estuarine sediments is caused by organic matter decay following the release of organically bound metals in the water column.

The dominant trace metal form in estuarine sediments is incorporated in minerals obtained by heating of samples with $1: 1 \mathrm{HNO}_{3}$. This fraction makes up an average $60-90 \%$ of the total contents for all the elements determined. This fraction probably contains metals bound with both $\mathrm{Fe}$ and $\mathrm{Mn}$ hydroxides and incorporated in clay and detrital minerals, which are flocculated in the estuarine water mixing zone by inorganic salts. Further growth and sedimentation of the particles leads to the accumulation of metals in mineral form in the estuarine sediments.

The total metal contents in the sediments were used for a pollution level estimation of estuaries. Therefore, Dwina and Pechora sediments show relative enrichment in all the metals and greater content of $\mathrm{Zn}$, which can serve as an indicator of anthropogenic input into the river discharges. 


\section{Allozyme Variation Upstream and} Downstream of Metal Contaminants in the Brown Trout (Salmo trutta) and Caddis Fly Arctopsyche grandis) in Clear Creek, Colorado, USA

\author{
'MARTIN, Lori M., ' MITTON, Jeffry B., ' ${ }^{2}$ REISER, Brian R., and \\ 'WOODLING, John D. \\ 'Colorado Division of Wildlife, 6060 Broadway, Denver, $C O$ \\ 80216, USA \\ ${ }^{2}$ University of Colorado, EPOB, Boulder, CO 80309, USA
}

In Colorado, metal concentrations in more than 2,080 kilometers of mountain streams exceed state water quality standards. One such stream, Clear Creek, originates at the Continental Divide and flows eastward to its confluence with the South Platte River north of Denver, Colorado. In 1982, the USEPA ranked Clear Creek as No. 174 on the National Priority List for Superfund sites. One significant source of metals, the Argo Tunnel, discharges more than 1,430 kilograms of aluminum, iron, manganese, and zinc into Clear Creek daily. Starch-gel electrophoresis was used to examine genetic variation in the brown trout (Salmo trutta) and caddis fly (Arctopsyche grandis) collected from Clear Creek sites upstream and downstream of the Argo Tunnel. Allelic frequencies in brown trout liver tissue at the glucose phosphate isomerase (GPI) locus were significantly different $\left(x^{2}=6.453, p<0.05\right)$ between the upstream and downstream ites. Two alleles ( $a$ and $b$ ) were present in both the homozygous and heterozygous conditions at the upstream site, whereas only individuals homozygous for the (b) allele were found at the downstream site. Preliminary work on Arctopsyche grandis suggests that allelic variation exists between the upstream and downstream sites. These differences may be attributable to the presence of metal contaminants in Clear Creek. The literature suggests that selection against the heterozygote genotype at the GPI locus occurs in species exposed to metal contaminants. Genetic bioindicators may prove to be appropriate for adoption as biological stream standards to monitor the effects of mining on aquatic communities.

\section{Solid Phase AAS - A New Old Technique: First Results with Environmental Material}

\author{
MATSCHULLAT, Jörg and UERPMANN, Carsten \\ Institute for Environmental Geochemistry, Heidelberg University, \\ P.O.Box 1030 20, D-69020, Heidelberg, Germany
}

A standard high resolution GF-AAS (AAS 5 EA by Carl Zeiss, Jena) has been altered slightly to enable solid samples to be processed in a very simple, fast and economic way. Vevertheless, sample handling requires utmost care to avoid contamination but standard laboratory equipment is sufficient to maintain satisfying results. Dried and finely ground samples (Pulverisette 6 by Fritsch and MM 2000 by Retsch) are transferred from their container to a small graphite platform (inweight 5-100 $\mu \mathrm{g}$; MC5 by Sartorius and UMT by Mettler Toledo). The subsequent pyrolysis and atomization (eventually preceded by a short additional drying step) takes between 30 and 80 seconds total. Due to the absence of more advanced drying and mixing techniques (addition of matrix modifiers or ionization buffers), up to 150 samples can be processed per work-day even with the current manual sample port.

The calibration was done with certified reference material (STSD 1-4; siliceous stream sediment) which has been processed like any ordinary sample (Table 1). Care was taken to use a wide range of inweights to obtain an appropriate concentration range for the subsequent analyses. RSD's were usually below $10 \%$ over the full concentration range. The determination limits were two to three orders of magnitude below conventional GF-AAS and can easily compete with laser-ablation ICP-MS - with the exception that only single element determinations can be performed.

\begin{tabular}{llll}
\hline \multicolumn{4}{c}{ Table 1. Measured detection and determination limits for CRM STSD $1,3,4$} \\
& $\mathrm{Cd}(\mathrm{n}=10)$ & $\mathrm{Ag}(\mathrm{n}=10)$ & $\mathrm{Be}(\mathrm{n}=10)$ \\
sample inweight $(\mu \mathrm{g})$ & $9-550$ & $2-100$ & $19-320$ \\
pyrolysis $\left({ }^{\circ} \mathrm{C}\right)$ & 670 & 650 & 1600 \\
atomization $\left({ }^{\circ} \mathrm{C}\right)$ & 1850 & 2200 & 2650 \\
detection limit $(\mathrm{pg})$ & $10 \mathrm{pg} \pm 30 \% \mathrm{rsd}$ & $2.7 \mathrm{pg} \pm 30 \% \mathrm{rsd}$ & $42 \mathrm{pg} \pm 30 \%$ rsd \\
determination limit $(\mathrm{pg})$ & $37 \mathrm{pg} \pm 30 \% \mathrm{rsd}$ & $9.9 \mathrm{pg} \pm 30 \% \mathrm{rsd}$ & $84 \mathrm{pg} \pm 30 \% \mathrm{rsd}$ \\
given conc $\left(\mathrm{mg} \mathrm{kg}^{-1}\right)$ & $0.8,1.0,0.6$ & $<0.5,<0.5,<0.5$ & $1.6,2.6,1.7$ \\
\hline
\end{tabular}

Applications for this new old technique are widespread and reach from trace element determinations, e.g., in single minerals including evaporitic salts to the direct analysis of more exotic elements in conventional rock, sediment and soil material. At the same time, reproducible element determinations on micro-samples for material science, forensic and criminal investigations become possible without potentially contaminating preparation techniques.

\section{What Is Background? A Statistical Approach, Introduced with Data for the Baltic Sea}

MATSCHULLAT, Jörg

Institute for Environmental Geochemistry, Heidelberg University, P.O.Box 1030 20, D-69020, Heidelberg, Germany

To quantify the geochemical background for trace elements is crucial to many applied and theoretical geochemical models. It is obvious, however, that a global background as useful as it is for global element cycling models, does not help to answer questions on a regional or local level. Therefore, the respective background will have to be assessed directly. To gather new data is very costly and time-consuming. If lesser requirements for the accuracy are demanded, the statistical analysis of large data sets, e.g., from environmental monitoring, yields the necessary information on both the variable influence of anthropogenic activity and on the geochemical background for trace elements in the investigated medium.

Exploratory data analysis (EDA) usually dissects the 
data set into percentiles. While the $25^{\text {th }}$ to $75^{\text {th }}$ percentile represent the bulk of the influenced data set, and values above the $90^{\text {th }}$ or below the $10^{\text {th }}$ percentile show outliers, the $10^{\text {th }}$ percentile can be used in a first approximation as a background value for the respective element. The basis for this simplistic hypothesis is the fact that anthropogenically emitted elements do not disperse homogeneously into the environment, but show a distribution which reveals the large concentration variability that makes it necessary to gather long time series for a representative data set. This variability includes a high statistical probability to encounter minimal concentrations, representative for the respective background. Examples for atmospheric and fresh water trace element concentrations, measured as influxes to the Baltic Sea and compared with recent literature values (Table 1) show the beauty of this approach, since calculated data $\left(10^{\text {th }}\right.$ percentiles) and recent measured data show a high compatibility.

Table 1. Comparison of EDA data for atmospheric (total deposition) and fresh water trace element concentrations

\begin{tabular}{lllll} 
& \multicolumn{2}{l}{ Atmosphere $\left(\mu \mathrm{g} L^{-1}\right)$} & \multicolumn{2}{l}{ Freshwater $(\mu \mathrm{g} \mathrm{L-1})$} \\
& $10^{\text {n }}$ Percentile & literature* & $10^{\text {n Percentile }}$ & literature** \\
$\mathrm{Cd}$ & 0.05 & 0.15 & 0.01 & $0.009-0.025$ \\
$\mathrm{Cu}$ & 0.6 & 1.20 & 0.5 & $1.0-1.4$ \\
$\mathrm{~Pb}$ & 2.0 & 5.00 & 0.1 & $0.08-0.2$ \\
$\mathrm{Zn}$ & 10.0 & 30.0 & 3.0 & $6-7$
\end{tabular}

"the data compiled by Brügmann and Matschullat (1997) include anthropogenic influences;

"data from Danielson (1982) for two major Swedish rivers.

A prerequisite to use large data sets in the described fashion, however, is a tight quality control on these data. This may be illustrated by the pre-1980 data sets for marine waters which gave generally too high concentrations due to sample contamination. The increased awareness towards quality control and the enhanced analytical capabilities in the trace and ultra-trace regime available now, result in much more reliable and accurate data sets which may be used to calculate postulated background values.

\section{Crustose Lichens - Capable of Monitoring the Atmospheric Deposition of Trace Elements and Organohalogens?}

MATSCHULLAT, Jörg, GARBE-SCHÖNBERG, Dieter, PEITER, Gerhard, SCHARNWEBER, Tim, and WIRTH, Volker

Institute for Environmental Geochemistry, Heidelberg University, P.O.Box 1030 20, D-69020, Heidelberg, Germany

In the summer of 1996, crustose lichens (composite samples, mainly Xanthoria elegans in Canada, Lecanora muralis in Germany) were gathered from the sides of silicic gravestones (granites, gneisses, sometimes sandstones) at 17 locations in Ontario, Canada (from Lake Ontario to James Bay) and 40 locations in Germany (from the Alps to the
North Sea and from the Baltic Sea to the Erzgebirge) on North-South transects.

Parallel to species determination, two sample aliquots were digested $\left(\mathrm{HNO}_{3}\right.$ p.a.) and analyzed for $\mathrm{As}, \mathrm{Ba}, \mathrm{Bi}, \mathrm{Cd}$, $\mathrm{Ce}, \mathrm{Co}, \mathrm{Cr}, \mathrm{Cs}, \mathrm{Cu}, \mathrm{La}, \mathrm{Mn}, \mathrm{Mo}, \mathrm{Nd}, \mathrm{Pb}, \mathrm{Pr}, \mathrm{Rb}, \mathrm{Sb}, \mathrm{Sn}, \mathrm{Sr}$, Th, Tl, U, V, Y, and Zn by AAS-, ICP-OES, and ICP-MS techniques. Simultaneously, the organohalogens were determined as adsorbable organic halogens (AOX) by coulometry.

The AOX varied widely between 24 and $940 \mathrm{mg} \mathrm{kg}^{-1}$. No direct relation could be found between trace element and AOX-concentrations. The AOX is neither dependent on atmospheric deposition nor to locality, but seems to reflect individual metabolic rates- the internal production of organohalogens by the organism itself.

Element concentration ranges $\left(\mathrm{mg} \mathrm{kg}^{-1}\right)$ in all samples were for As (0.1-170), Ba (16-670), Bi (0.1-17), Cd (0.513), Ce (4-170), Co (1-16), Cr (15-270), Cs (0.3-7.4), Cu (8-230), La (2-87), Mn (35-1990), Mo (1-10), Nd (1.675), Pb (17-2100), Pr (0.5-21), Rb (3-90), Sb (0.3-8), Sn (1-130), Sr (16-370), Th (0.3-17), Tl (0.07-1), U (0.1-11), $\mathrm{V}(7-100), \mathrm{Y}(1.1-30)$, and $\mathrm{Zn}(50-1600)$. The results reveal a high resolution for spatial element distribution and allow for a detailed differentiation between natural and anthropogenic element emissions/immissions. The methods seems to be very sensitive and at the same time fast and reliable.

\section{Application of the Equilibrium Partitioning Method in Surficial Sediments near a Deepwater Ocean Outfall Off Malabar, Sydney, Australia}

\section{MATTHAI, C. and BIRCH, G.F.}

Dept. Geology and Geophysics, University of Sydney, NSW 2006, Australia.

The equilibrium partitioning method has been used to determine the impact of anthropogenic trace metal contaminant sources into the coastal marine environment. This study is designed to test the spatial relationship of the chemical composition of trace metal contaminants in the dissolved and solid phases of the surficial sediments adjacent to the deepwater ocean outfall off Malabar, Sydney. As a point source of $150 \mathrm{ML}$ of primary treated organic-rich sewage and industrial effluent into the mid shelf environment, the outfall impacts on the chemical composition of the adjacent surficial sediments. The extent and nature of this impact are of central concern to both environmental managers and legislators.

Triplicate core samples of undisturbed surficial sediments were analyzed on both bulk and size-normalized basis ( $<63 \mu \mathrm{m}$ fraction) to establish the extent of enrichment of heavy metals. Porewater and solid phase concentration ratios show whether sewage organic matter metabolism contributes to the dissolved phase trace metal concentrations in sediments close to the outfall. Early diagenetic processes could 
lead to a dissolved phase flux from the sediments into the overlying water column, where an uptake of bioavailable trace metal contaminants into the foodchain increases the ecological risk. Solid and dissolved phase trace metal profiles can be used as indicators of the prevailing geochemical conditions in marine sediments as well as assisting in evaluating their chemical and physical stability.

\section{Radiogeochemical Mapping in the Ignalina Nuclear Power Plant Region (Bottom Sediments and Soils)}

\author{
MAZEIKA, Jonas, and PETROSIUS, Rimantas \\ Institute of Geology, Sevcenkos 13, 2600 Vilnius, Lithuania
}

The aim of this work is to evaluate the radioecological situation in the Ignalina Nuclear Power Plant (INPP) region in water and terrestrial ecosystems by means of radiogeochemical mapping. Preliminary radiogeochemical mapping of bottom sediments on a scale of 1:50,000 was accomplished in 1995; that for soil mapping on a scale of $1: 100,000$ in 1996. There were 3 stages of investigations (all territory covered with a 1-km grid; coastal zone; monitoring areas) with different methodology. Radionuclide entry into the lake partly depends on the wash-out of the radionuclide emitted to the atmosphere. The investigations of terrestrial ecosystems show some areas with different 'ources of technogenic radionuclides in soil in the INPP region (radioactive waste storage, quarry of mud accumulation from Visaginas town and INPP waste treatment plant, coastal zone, local breakdown zones of water communications). The largest concentrations of technogenic radionuclides $\left({ }^{54} \mathrm{Mn}-32,{ }^{60} \mathrm{Co}-35,{ }^{137} \mathrm{Cs}-97,{ }^{134} \mathrm{Cs}-12 \mathrm{~Bq} \mathrm{~kg}{ }^{-1}\right.$ DW) in the topsoil samples were defined in small zones near the above mentioned areas. The largest concentrations of radionuclides $\left({ }^{54} \mathrm{Mn}-7,{ }^{60} \mathrm{Co}-160,{ }^{137} \mathrm{Cs}-5 \mathrm{~Bq} \mathrm{~m}^{-3}\right)$ in ground water in the area with maximal deposition of technogenic radionuclide (filter interval 20-25 $\mathrm{m}$ of depth) were defined. The first area (radioactive waste storage) is characterized by a diversity of radionuclide sources, migration of radionuclides in unconfined ground water, caused by vertical hydrodynamic factors and geochemical water - rock interaction. In the second area the source of radionuclides is concentrate mud, brought by lorries and poured in the quarry. Radionuclide transport occurs in the whole mass of mud because of microbiological activity in the mud. Deeper vertical penetration of radionuclides into the bedrock below a quarry has also occurred. Migration of technogenic radionuclides in the coastal zone is caused by interaction between terrestrial and water ecosystems. The distribution of technogenic radionuclides in soils shows that radionuclides which are emitted from INPP may be a minor source to the terrestrial ecosystem. The mechanism(s) of radionulide migration in soils and plants depend on the method of radioactive waste management, interactions in the coastal zone, and fallout intensity. Radionuclide concentration ratios in the bottom sediments show ${ }^{137} \mathrm{Cs}$ appearance in the lake (cooling basin) after the Chernobyl NPP accident, though Ignalina NPP has contributed, too. Due to discharges from the plant, radionuclides enter the water ecosystem through the atmosphere and with water. The greatest anomalies of ${ }^{137} \mathrm{Cs}$ are on the order of $67 \mathrm{~Bq} \mathrm{~kg}^{-1}$ FW. ${ }^{134} \mathrm{Cs}$ is observed in a majority of lake-bottom sediment samples in concentrations up to $6 \mathrm{~Bq} \mathrm{~kg}^{-1} \mathrm{FW}$ near the heated water outlet. The ${ }^{60} \mathrm{Co}$ and ${ }^{54} \mathrm{Mn}$ concentrations nearest the discharge area of the heated water are up to 23 and $7 \mathrm{~Bq} \mathrm{~kg}^{-1} \mathrm{FW}$. The distribution of technogenic radionuclides in the bottom sediments shows that radionuclides escape into the lake from the plant's main water operations. Radionuclide concentration levels do not exceed the control level and may be treated only as traced admixture.

\section{Distribution and Origin of Fluoride in Rural Drinking Water Supplies in the Western Bushveld Areas of South Africa}

\author{
McCAFFREY, Lewis $P$. and WILLIS, James $P$. \\ Department of Geological Sciences, University of Cape Town, \\ Rondebosch, 7700, South Africa
}

Elevated fluoride levels are reported from most areas of the western Bushveld surrounding the Pilanesberg Igneous Complex and those areas underlain by granitic rocks of the Bushveld Igneous Complex. About 300,000 people drink water with $\mathrm{F}^{-}$concentrations above the optimum $(\sim 0.7 \mathrm{mg}$ $\left.\mathrm{L}^{-1}\right)$. Dental fluorosis in both children and adults is clearly manifested in many villages, together with a few cases of severe skeletal fluorosis in adults. Ground-water samples were analyzed in the field for $\mathrm{F}^{-}$, temperature, $\mathrm{pH}, \mathrm{EC}, \mathrm{DO}$, and total alkalinity, and $\mathrm{F}^{-}$and other anions and cations were determined by HPIC in the laboratory. Major and trace element analysis of fresh rocks and associated soil samples was carried out by XRFS, and mineral analysis by electron microprobe. Leachable F- was determined in rocks and soils and related to ground-water samples from eight lithologies. Chemical and physical data from 320 new boreholes were evaluated together with 3,000 ground-water samples from the Department of Water Affairs and Forestry database. The source and mobility of $\mathrm{F}^{-}$in the hydrogeochemical environment of the area was established, and also the spatial relations between $\mathrm{F}^{-}$enriched ground waters and fluoride sources in rocks, mineralized areas and soils. A map of areas of zero, medium, high and very high fluorosis risk was compiled. In some parts $\mathrm{F}^{-}$levels exceeded South African guidelines by $800 \%$. 


\section{Lithogeochemical Map of the Chesapeake Bay Watershed-- An Example of Usable Repackaging of Traditional Geologic Information}

\author{
McCARTAN, Lucy and PEPER, John \\ 926 National Center, U.S. Geological Survey, Reston, VA 20192, \\ USA
}

Traditional geologic maps contain a wealth of information for many applications such as water availability and water quality investigations, identification and avoidance of natural hazards such as landslides and recent faults associated with earthquakes, discovery and development of surface resources such as aggregate deposits, and optimal siting of roads and landfills. Typically, an expert is required to translate the information given on the traditional maps into an applicable format. In conjunction with a broadbased effort to restore ecological health to Chesapeake Bay, baseline information, including regional-scale published geologic maps, was acquired for the 70,000 square-mile Chesapeake Bay watershed. The geology was portrayed as classical formations, which reflected the mappers' concepts of the age, structure, and geologic history of the rocks and sediments.

Mineralogical/chemical data were buried in map unit descriptions. Using a modification of a scheme developed by the USGS in Connecticut for use in ground-water quality studies, the approximately 350 classical formations were recast into about 33 lithogeochemical units. The new scheme emphasizes the effects of the mineralogy and texture of the units on the chemistry of water flowing through the rocks and sediments. Units containing sulfide, carbonaceous residue, and carbonate or resistate siliciclastic minerals are of particular importance. In this new form, geologic information is being used in the Chesapeake Bay watershed to help delineate natural nitrate filtration zones (high sulfide and carbon content), acid reduction zones (high carbonate content), and other natural anomalies. The new lithogeochemical map was compiled at 1:500,000; it will be available as a digital file from the U.S. Geological Survey.

\section{Geology and Geochemistry of Water and Stream-Sediment Samples of the Upper Pecos River, from the Southern Pecos Wilderness to Brantley Dam, North of Carlsbad, Eastern New Mexico}

\section{MCLEMORE, V. T. and BRANDVOLD, L. A. \\ New Mexico Bureau of Mines and Mineral Resources, Socorro, New Mexico 87801}

Water quality of the Pecos River has become a concern as population increases in eastern New Mexico resulting in an increase in demand for that water. Water and streamsediment samples were collected from the Pecos River from
September 1992 through September 1996 to assess the water quality. Chemical analyses confirm that elevated concentrations of $\mathrm{Cu}, \mathrm{Pb}, \mathrm{Zn}$, and $\mathrm{Cd}$ occur in stream sediments below both the Pecos mine and Alamitos Canyon mill sites.

Elevated concentrations of $\mathrm{Cs}, \mathrm{As}, \mathrm{Ag}, \mathrm{Au}, \mathrm{W}, \mathrm{Br}, \mathrm{Se}, \mathrm{Sb}$, and $\mathrm{Fe}$ are also found in stream sediments collected near the Pecos mine. Chemical analyses of six sediment size fractions from six sites suggest that the metals are predominantly traveling both as suspended material and as larger mineral or other grains weathered from the mine waste pile and the tailings pile. Partial dissolution techniques designed to estimate exchangeable, organic, and oxide-bound forms indicate that the largest amount of $\mathrm{Cu}$ and $\mathrm{Pb}$ were in forms solubilized by aqua regia but not by the three extraction techniques. The largest amount of $\mathrm{Zn}$ was associated with $\mathrm{Fe}$ and Mn oxides. Collectively, these multi-disciplinary studies suggest that $\mathrm{Cu}, \mathrm{Pb}, \mathrm{Zn}$, and other metals are eroded and leached from the Pecos mine dump and the tailings piles in Alamitos Canyon. However, the total metal addition from these sources is insignificant compared to sediment input from drainages south of the Pecos village. Drainage from the Pecos mine is not significantly affecting the composition of the surface and ground waters in the area, except in the immediate vicinity of the Pecos mine and mill site.

\section{Distribution of Trace Metals in Soils near the Base Metal Smelter at Flin Flon, Manitoba: Natural and Anthropogenic Enrichments from A Remote Single Point} Source Area

\author{
MCMARTIN, I. and HENDERSON, P.J. \\ Geological Survey of Canada, 601 Booth St., Ottawa, KIA OE8, \\ Canada
}

The distribution and nature of trace metals emitted from the base metal smelter at Flin Flon were examined in surface soils and at depth, using an extensive regional database for humus and the underlying till, and detailed chemical and mineralogical analysis of selected samples in transects, soil profiles and background sites. The purpose of this study was to determine the extent of smelter contamination, the relative contribution of emitted metals from natural and anthropogenic sources and the storage sites for emissions. Regional metal dispersal patterns reflect the historical record of smelter contamination. Concentrations of smelter metals (As, $\mathrm{Cd}, \mathrm{Cu}, \mathrm{Hg}, \mathrm{Pb}, \mathrm{Zn}$ ) in humus decrease rapidly with increasing distance from the smelter, approaching background values at distances averaging $85 \mathrm{~km}$, depending on the element, the predominant wind directions and the background value determined for that element. In humus, the average proportion of smelter metal concentrations associated with an anthropogenic origin decreases from a maximum of $99.3 \%$ in the vicinity of the smelter $(<4 \mathrm{~km})$ to $43.9 \%$ at $50 \mathrm{~km}$ from the smelter. Results from detailed analysis indicate that metal particles in humus occur as spheres, irregular grains, and with organics. Chemical 
partitioning of $\mathrm{Zn}, \mathrm{Pb}, \mathrm{Cd}$ and $\mathrm{Cu}$ is controlled mainly by the total organic content of the humus, and these elements are held primarily in an easily leachable (labile) form. $\mathrm{Hg}$ and As are largely associated with the non-labile phases, hence sre less mobile than the other smelter metals. Smelter contamination is restricted to the surface organic-rich horizons, except at highly contaminated sites $(<10 \mathrm{~km}$ from smelter), where smelter metals have migrated down the soil profile, at least to $45 \mathrm{~cm}$ depth.

\section{The Spatial Reliability of Geochemical Maps}

\author{
McNEAL, James $M$. \\ U.S. Geological Survey, 910 National Center, Reston, VA 20192
}

The increasing importance of the environmental geochemistry of potentially toxic elements in the environment is leading to an increased interest in the determination of geochemical baselines and the preparation of geochemical maps. Geochemical baselines are important because they serve as a means of defining normal concentrations of an element in a sample so that unusual samples can be reliably identified. Geochemical baselines are relatively easy to determine; they are typically defined as the mean plus or minus two standard deviation units of all of the element concentrations of samples from the target population. Care must be taken to assure that the target population was well defined and that the samples were collected and analyzed in .n unbiased manner.

Because most geologic materials used for preparing geochemical baselines are collected on a spatial basis, there is commonly a need to display the data on a map base so that patterns in the data can be observed and interpreted as trends. The reliability of these geochemical patterns must be determined before rigorous data interpretations are made. If the geochemical pattern is not reliable (that is, has a low probability of being reproduced with a new set of samples), then the geochemical trends and associated data interpretations may not be reliable. A method for determining the spatial reliability of geochemical maps will be reviewed and examples will be given.

\section{Anthropogenic and Geogenic Sources of Trace Metals in the Environment-A Case Study of Contaminated Soils in the Pezinok- Pernek Region of Malé Karpaty Mountains, Slovakia}

\author{
MEJEED, Salem Yaseen, VESELSKÝ, Josef, and FORGÁČ Jozef \\ Department of Geochemistry, Faculty of Natural Sciences, \\ Comenius University, Mlynská dolina, 84215 Bratislava, Slovakia
}

Distribution of many trace metals (As, $\mathrm{Cd}, \mathrm{Co}, \mathrm{Cr}, \mathrm{Cu}, \mathrm{Hg}$, $\mathrm{Ni}, \mathrm{Pb}, \mathrm{Sb}, \mathrm{Se}$ and $\mathrm{Zn}$ ) has been determined in soils in the Pezinok Karpaty Mountains Region which is considered a protected landscape area within the Malé Karpaty (Small
Karpathians) Region in the southwestern part of Slovakian territories close to the capital city of Bratislava. Total concentrations of many trace elements have been determined in soils of the studied area. Soils have been sampled at depths of $0-5 \mathrm{~cm}, 5-20 \mathrm{~cm}$, and $20-40 \mathrm{~cm}$. Sampling localities have been selected on several tracks situated transversely to the mentioned mountains. Some of these tracks have been selected to reflect more or less geological influences of substrate, others the anthropogenic influence of previous mining and smelting activities in the region.

The results were compared according to soil horizons, different tracks, different substrate, and different land use. Higher levels of many trace metals in the track PernekPezinok relative to other tracks indicate the anthropogenic influence of mining and smelting activities there. Geological influence is also evident where, generally, most trace metals are enhanced in soils developed on shales and phyllites. This is also clear when comparing soils according to land use. Most trace metals are enriched in forest soils, which represent mountainous soils, relative to agricultural soils of piedmont area developed on sand. Higher humus contents in the forest soils is also contributing to the higher metal levels in this case. All trace metals also show higher concentrations in the uppermost soil horizons.

\section{Soil $\mathrm{Pb}, \mathrm{Zn}$, and $\mathrm{Cd}$ in Metropolitan New Orleans-Their Geochemical Characterization and Association}

\author{
MIELKE, Howard W. and SMITH, M. Kelley \\ Xavier University of Louisiana, Institute of Bioenvironmental \\ Toxicology, New Orleans, LA 70I25, USA
}

The raw data for this study is 4,024 soil samples collected from all sections of metropolitan New Orleans. Samples were dried, sieved ( $2 \mathrm{~mm}$ screen), extracted with $1 \mathrm{~mol} \mathrm{~L}^{-1}$ nitric acid solution for 2 hours at room temperature, and filtered. Background correction due to $\mathrm{Al}$ interference was required for measurement of $\mathrm{Pb}$ with the ICP-AES. The extracts were analyzed using AAS for $\mathrm{Pb}$ and ICP-AES for $\mathrm{Pb}, \mathrm{Zn}$, and $\mathrm{Cd}$. The main purpose of this study is to characterize the association between various metals in the soils of New Orleans and, secondarily, to compare the results between AAS and ICP-AES. Table 1 lists the results for the two analyses for $\mathrm{Pb}$, and the ICP results for $\mathrm{Zn}$, and Cd.

\begin{tabular}{|c|c|c|c|c|c|c|c|c|}
\hline & $\mathrm{N}$ & Min & $10 \%$ & $25 \%$ & $50 \%$ & $75 \%$ & $90 \%$ & Max \\
\hline PbAAS & 4,024 & 1.0 & 14.0 & 42.0 & 127 & 354 & 860 & 69,000 \\
\hline $\mathrm{Pb}$ (ICP) & 4,024 & 0.2 & 12.4 & 36.6 & 120 & 330 & 813 & 191,000 \\
\hline $\mathrm{Zn}$ & 4,024 & $<0.1$ & 25.4 & 54.4 & 131 & 312 & 735 & 26,600 \\
\hline $\mathrm{Cd}$ & 4,024 & $<0.1$ & 0.9 & 1.7 & 3.2 & 5.2 & 7.5 & 87 \\
\hline
\end{tabular}

Except for the maximum value, the ICP results are lower than the AAS results. A Mann-Whitney Rank Sum Test was used to evaluate the degree of similarity of the results. The differences between the median values among the two groups are greater than expected by chance $(p$ value $<$ 
$0.018)$. Given the size of the data base this is not a large difference. Note that differences between the analytical results at 25,50 and 75 percentile are $5.4,6.6$ and $24.2 \mathrm{mg}$ $\mathrm{kg}^{-1}$ respectively. The quantities of $\mathrm{Zn}$ are similar to $\mathrm{Pb}$. The association for the range of analytical results is given in Table 2 .

Table 2.

$\mathrm{N}=4,024$

$\mathrm{Pb}$ (AAS)

$p$ value

$\mathrm{Pb}(\mathrm{ICP})$

$p$ value

$\mathrm{Zn}$

p value

The associations for these paired results, especially for $\mathrm{Pb}$ (AAS) and $\mathrm{Pb}$ (ICP), $\mathrm{Pb}$ and $\mathrm{Zn}$, and $\mathrm{Zn}$ and $\mathrm{Cd}$ are extremely significant and not a product of chance. A consequence of this finding is that the geochemical distribution of one metal predicts the occurrence of the other two metals.

\section{Geochemistry and Water Quality Prediction} for Skarn Deposits in the New World Mining District

\section{MILLER, Rebecca A. and GURRIERI, Joe T.}

Montana Department of Environmental Quality, P.O. Box 200901, Helena, MT 59620, USA

The New World Mining District is comprised of oxidized skarn deposits within the Fisher Mountain Intrusive Complex (FMIC) and unoxidized massive sulfide skarn deposits of the Homestake Intrusive Complex (HIC). Based on the occurrence of local Cambrian carbonate geology, knowledge of the deposit geology and adit water quality associated with these complexes, predictions may be made as to the future water quality associated with previously proposed mining development in the New World District.

The FMIC is characterized by the advanced degree of oxidation that has taken place since the last retreat of glaciation. These oxidized skarn deposits are located at the top of a cirque and consequently have been exposed to weathering and oxidation for at least 10,000 years. It is not surprising that adit discharges from these historical mine workings are acidic ( $\mathrm{pH} 3.2$ ), with no bicarbonate but elevated sulfate ( $\left.408 \mathrm{mg} \mathrm{L}^{-1}\right)$ and metals concentrations (77.17 $\mathrm{mg} \mathrm{L}^{-1}$ total recoverable $\mathrm{Al}+\mathrm{F} \mathrm{e}+\mathrm{Cu}+\mathrm{Ag}+\mathrm{Cr}+$ $\mathrm{Mn}+\mathrm{Pb}+\mathrm{Ni}+\mathrm{Zn}$ ). However, downgradient of economic sulfide mineralization, the local carbonate geology buffers the acidic drainage to near neutral.

In contrast, the HIC is not oxidized to an appreciable extent as it occurs deep within Henderson Mountain. Water quality data from the historical Gold Dust Adit indicate that sulfide oxidation is occurring with an average sulfate concentration of $252 \mathrm{mg} / \mathrm{L}$ and an average dissolved iron concentration of $0.23 \mathrm{mg} \mathrm{L}^{-1}$. However, a near neutral $\mathrm{pH}$ (7.3) and moderate bicarbonate (112 $\left.\mathrm{mg} \mathrm{L}^{-1}\right)$, calcium (94 $\left.\mathrm{mg} \mathrm{L}^{-1}\right)$ and magnesium ( $27 \mathrm{mg} / \mathrm{L}$ ) concentrations indicate that acidity is buffered by the deposit geology. Adit water quality data corroborate kinetic testing. Humidity cell data demonstrate slow to moderate oxidation rates $(0$ to $40 \mathrm{mg}$ $\mathrm{SO}_{4}^{-2} \mathrm{~kg}^{-1} \mathrm{wk}^{-1}$ ).

Based on existing water quality condition and humidity cell data, neutral $\mathrm{pH}$, moderate bicarbonate $\left(>120 \mathrm{mg} \mathrm{L}^{-1}\right)$, sulfate (circa $500 \mathrm{mg} \mathrm{L}^{-1}$ ), and metal (10 to $100 \mathrm{mg} \mathrm{L}^{-1}$ total recoverable $\mathrm{Al}+\mathrm{Fe}+\mathrm{Cu}+\mathrm{Ag}+\mathrm{Cr}+\mathrm{Mn}+\mathrm{Pb}+\mathrm{Ni}+\mathrm{Zn}$ ) concentrations are considered to be likely for adit discharges during mining.

\section{Aluminum and Iron Mobility in an Acid Sulfate Environment and Consequences for Local Population-- The Case of the Lower Casamance (Senegal)}

\section{MONTOROI, J.P. \\ Orstom, 32 Avenue Henri Varagnat, 93143 Bondy, France}

Since 1970, the main effects of the drought in the Lower Casamance, especially in the mangrove environment, have been: the increase of the salinity of seawater, concentrated by evaporation; the chemical degradation of soils in lowlands; the decrease of the mangrove vegetation; and the decrease of rice production. Natural oxidation of the mangrove pyritic sediments has extended into the mangrove area and the acid sulfate soils have increased. The production of sulfuric acid in soils leads to the hydrolysis of the clay fraction of soils and to the release of metal elements, such as $\mathrm{Al}$, in the soil solution and in the ground water. So, high concentrations of dissolved $\mathrm{Al}$ and $\mathrm{Fe}$ have been found in acid sulfate soil waters, especially in watersheds equipped with an anti-salt dam. A toxic hazard is assumed to be effective against fauna and vegetation, especially rice culture, and is potential for man. In this paper, we present the main results of a field study carried out in degraded valleys of the Lower Casamance. We show how the Al- and Fe- sulfate minerals occur in the environment and how we can explain their formation. The influence of $\mathrm{Al}$ on living organisms, such as fishes, is also exposed and the ecological problem is discussed.

\section{Heavy Metal Distribution and Environmental Status of Doon Valley Soils, U.P. India}

MUKHERJEE, P.K., SAINI, N.K., RATHI, M.S., KHANNA, P.P., PUROHIT, K.K. and SRIRAM, V.

Wadia Institute of Himalayan Geology, 33, Gen. Mahadeo Singh Road, Dehra Dun, 248001 , India

Doon Valley is surrounded by two major river systems (Ganga and Yamuna) on either side with a water divide passing nearly across the center of the valley and sand- 
wiched between two mountain ranges in the fragile ecological systems of the Himalayan foot hills. About 400 soil samples were collected in a grid pattern $(\sim 1$ sample per two $\mathrm{km}^{2}$ ) and investigated for their heavy metal abundance. The reavy metal abundance of Doon valley soils, when compared with the uncontaminated and trigger threshold values, reveal that most of these elemental abundances fall in the range of uncontaminated to slightly contaminated category. However, in the case of $\mathrm{Cr},>70 \%$ of samples exceed the trigger value ( $>100 \mathrm{mg} \mathrm{kg}^{-1}$ ) and it goes as high as $413 \mathrm{mg}$ $\mathrm{kg}^{-1}$ with an overall background value of $108 \mathrm{mg} \mathrm{kg}^{-1}$ and are of some concern that needs immediate attention. Sites of high $\mathrm{Cr}$ occur mostly in the Ganga catchment sector, even in relatively undisturbed forest land. The source of this contamination is attributed to geological factors, particularly contribution from mafic volcanics of Lesser Himalaya. This is also consistent with the distribution pattern of $\mathrm{Ni}, \mathrm{Mn}$, and $\mathrm{Fe}$, though their abundance levels are not alarming. Barring an anomalous site near the south central sector, the $\mathrm{Zn}$ concentration in this area is largely within safe limits. Range and background concentration of $\mathrm{Pb}$ is low (5-165 and 22 $\mathrm{mg} \mathrm{kg}^{-1}$ respectively), however, signs of gradual $\mathrm{Pb}$ contamination can be observed in and around the center of the city and along the highways. In terms of $\mathrm{Zn}$ and $\mathrm{Ni}$, the SE part of the area may be regarded as slightly contaminated.

Except for the $\mathrm{Pb}$, the distribution pattern of the heavy metals in Doon Valley is largely controlled by lithogenic and geomorphological factors.

\section{Purifying Toxic Metal Contaminated Ground Water by Chitosan in Partially Converted Crab Shell}

\author{
NI, Dagang \\ Comtrol Services Co. 2718 Westside Dr. Houston, TX 77502
}

Aqueous samples collected from ground water near a chemical plant include some heavy metals, such as $\mathrm{Cu}$ and $\mathrm{Pb}$. The contamination may influence the suitability of downstream water for various uses. Of technologies that have been developed over the years to remove toxic metal ions from water, all have inherent advantages and limitations. Chitosan, a main derivative of chitin which is a polysaccharide and waste product from the seafood processing industry, is a successful chelation ion exchange agent. As opposed to simple ion exchange, chitosan takes advantage of the three-dimensional structure of molecules to chelate and remove ions of a specific size in the presence of large quantities of other ions. Chitosan is an excellent sorbent for transition metal ions. Chitosan was prepared using partially converted Gulf Coast blue crab shell waste. In this work, the characteristics of metal adsorption by chitosan was studied. The experiments were performed to .vestigate the kinetics, isotherms, adsorption capacity, the effect of $\mathrm{pH}$, metal ion concentration, and crab shell consumption. Chitosan not only has a rather high adsorption capacity, but also is capable of lowering transition metal ion concentrations to sub part per billion levels. The metal ion concentration gradient is a fundamental force that transfers metal ions from solution to adsorbent surface and diffuses metal ion into the adsorbent. When the crab shell loading is changed, the adsorbent surface of adsorbent sites will be changed sequentially, which determines the uptake rate, and the equilibrium metal ion concentration. The $\mathrm{pH}$ value greatly influences the adsorption. In acidic conditions, adsorption increases with increasing $\mathrm{pH}$, and the maximum adsorption occurs at about $\mathrm{pH} 6$ for both $\mathrm{Cu}$ and $\mathrm{Pb}$. The crab shell surface is not homogeneous, and the adsorption process should be complicated. The adsorption isotherms don't match the Langmuir function, but can be described by Freundlich isotherms well. The adsorption of transition metal ions by chitosan in crab shell wastes performs ion exchange chelating mechanism. The excellent adsorption behavior of chitosan may be attributed to stable fivemembered chelate rings coordinated through amino grouts. Advantages of the chitosan in partially converted crab shell waste include availability, low cost, high biocompatibility and easy retrieval. The observed results indicate that the chitosan in partially converted crab shell waste has the potential as a purifying agent in large-scale facilities to uptake heavy metals from contaminated ground water.

\section{Environmental Geochemistry of Boron}

\author{
NICHOLSON, Keith and WOOD, John \\ Environmental Geochemistry Research Group, The Robert \\ Gordon University, St. Andrew Street, Aberdeen, AB25 IHG, \\ Scotland
}

Concern over increasing boron levels in rivers receiving domestic and industrial effluent was highlighted in a recent EU report (1). The problem of boron accumulation arises through two factors: repeated reuse of increasingly limited surface water supplies and the lack of removal of boron by conventional treatment methods. The $1995 \mathrm{EU}$ review of current potable water regulatory limits for boron, and the concluding report further highlighted the lack of recent toxicity or monitoring data (1). Recent concern over boron levels has also been expressed in the USA (2) where an estimated 32,000 tonnes of boron effluent are discharged annually. The predominant source of boron discharges world-wide is detergents (2) (ca. 40\%), but other sources include agricultural products (3) such as coal (4), nuclear (4) and geothermal (5) power stations; mining (6) and the glass and ceramics industry (7). Additionally, borates represent a common component of domestic discharges. Given that borates are not removed by conventional water treatment processes, and at high levels may actually destroy bacteriological-based treatment systems (4),the situation in England, for example, is potentially acute with the combination of high population density, high detergent use and increasingly low flow rates in surface water supplies-a situation which will be exacerbated if climate change predictions prove correct. The need for monitoring boron levels is further highlighted by the use of surface waters as a source for 
potable and agricultural supplies, since although an essential element for plant growth, the range between acceptable and toxic boron concentrations is small, (c.1 $4 \mathrm{mg} \mathrm{kg}^{-1}$ ). A simple, rapid method of determination for routine monitoring of waters, effluents and sludges is needed. The latter is of particular importance given the impending disposal of sewage sludge onto agricultural land. The WHO potable water limit for boron is $0.3 \mathrm{mg} \mathrm{L}^{-1}$; however, the recommended determination methods (8) are based on spectrophotometric techniques which lack the required precision and/or detection limit. Our investigation used ISE, AA and IC methods for the determination of $\mathrm{B}(\mathrm{OH})_{3}$ or $\mathrm{B}(\mathrm{OH})_{4}^{-}$, the most common dissolved boron species based on the equilibrium:

$$
\mathrm{B}(\mathrm{OH})_{3}+\mathrm{OH}^{-}=\mathrm{B}(\mathrm{OH})_{4}^{-} \quad \mathrm{pK} \mathrm{B}(\mathrm{OH})_{3}=9
$$

When $\mathrm{pH}>\mathrm{pK} \mathrm{B}(\mathrm{OH})_{3}$ then $\mathrm{B}(\mathrm{OH})_{4}{ }^{-}$becomes dominant and represents the principal species above about $\mathrm{pH} 11$. Prior to this study, little work has been undertaken on the adaptation of IC or the fluoroborate electrode to this application. We evaluated these techniques in detail, but the open use of hydrofluoric acid as part of the analysis prejudices its use for some applications on safety considerations.

\footnotetext{
1. EC Scientific Advisory Committee, 1996, Report CSTE/96/4/V, Brussels, 20th Feb., 10 pp.

2. US Dept of the Interior, 1990, Biological Report 85.

3. Grinstead, R.R. and Wheaton, R.M., 1971, US Dept of the Interior, Research and development report 721.

4. Wong, J., 1984, Environmental progress, 3, 5-11.

5. Nicholson, K., 1992, In: Sayigh, A.A.M. (Editor) Renewable energy, technology and the environment, Pergamon Press, 2895-2899.

6. Okay, O. et al., 1985, Water Research, 19, 857-862.

7. Busani, G. and Timellini, G., 1993, Ceram. Eng. Sci. Proc., 14, $457-$ 467.

8. DOE Standing Committee of Analysts (1980), Boron in water effluents, sewage and some solids: HMSO, London.
}

\section{The Use of Two Leaches in Environmental Geochemical Mapping to Assess Concentration Levels and Mobilities of \\ Elements in Soils}

\author{
NISKAVAARA, Heikki ${ }^{\prime}, \ddot{A} Y R \ddot{A} S, M a t i^{\prime}$, REIMANN, Clemens ${ }^{2}, D E$ \\ CARITAT, Patrice ${ }^{2}$, CHEKUSHIN, Viktor ${ }^{3}$ and PAVLOV, \\ Vladimir ${ }^{3}$ \\ 'Geological Survey of Finland, P.O. Box 77, FIN-9610I, \\ Rovaniemi, Finland \\ ${ }^{2}$ Geological Survey of Norway, P.O. Box 3006, Lade, N-7002, \\ Trondheim, Norway \\ ${ }^{3}$ Central Kola Expedition, Fersman st. 26, 184200, Apatity, Russia
}

A simple procedure comprising two leaches was applied for topsoil and humus samples to estimate element levels, distribution and mobilities of 19 elements. Total concentrations were determined using strong acid leaches. For topsoil samples which are composites of mineral and organic material an aqua regia digestion was used (ISO 11466 standard). For organic soils (humus) a microwave assisted digestion using concentrated nitric acid was used (US EPA method 3050). The other leach applied both for topsoil and humus samples was a $1 \mathrm{M}$ ammonium acetate leach buffered to $\mathrm{pH}$ 4.5. This weak leach will extract soluble, adsorbed and exchangeable elements from soil samples. Buffering to acid $\mathrm{pH}$ will, however, liberate also some parts of heavy metals from precipitated secondary minerals (hydroxides etc.). The selected $\mathrm{pH}$ represents the conditions of acid rain and snow melt water, which is one of the most important factors affecting element leaching from topsoil during the snow melting period in the Arctic.

This approach was used in two different scales in environmental geochemical mapping during the International Ecogeochemistry Kola Project (1992-1996). Topsoil (topmost 0-5 cm) samples collected from eight different catchments were analyzed with these techniques. A total of about 20 samples were collected within each catchment to give insight of spatial variation. Temporal variations were also studied repeating the sampling four times during a year. Regional humus (AO) samples with density of one sample per $300 \mathrm{~km}^{2}$ in an area covering about $188,000 \mathrm{~km}^{2}(673$ stations) were also analyzed applying the same techniques. The total concentrations will give a direct indication of pollution status by comparing different background concentrations in different geochemical (bedrock and quaternary geology) or geographical landscapes (vicinity of seas, altitude). The weak leach used will give information on easily leachable (soluble, adsorbed, exchangeable) concentrations of elements in different soil types. Each individual element has its proportion of easy leachability in the natural environment. This proportion can vary due to different effects - anthropogenic and natural airborne deposition, nature of parent material (bedrock, soil formation, vegetation), etc. The proportions can be used to identify these deviations and estimate the status of the soil studied (exchangeable cations, soluble and adsorbed heavy metals and sulfur).

\section{Three-Dimensional Nanocrystalline Networks Limit Limestone Drain Remediation: A Role for Environmental Mineralogy.}

\author{
NORD, Gordon L., Jr.' , ROBBINS, Eleanora I.', and LIVI, Ken \\ J.T. ${ }^{2}$ \\ 'U.S. Geological Survey, Reston, VA, 20192, USA \\ ${ }^{2} J o h n s$ Hopkins University, Baltimore, MD, USA
}

Anoxic limestone drains (ALD) are among the many technologies being tested to reduce acidity and remove metals from streams affected by acid mine drainage. Many ALD's fail because the limestone gravel becomes clogged with a slimy white $\mathrm{Al}$-rich precipitate.

One such failure occurred in the Ridenour Rural and Abandoned Mineland Program (RAMP) Monongalia Co., WV. The white precipitate, viewed in transmission and scanning electron microscopy, consists of an open meshwork of connected spheres, rod-shaped prisms and bacteria. Analytical electron microscopy indicates that the spheres 
contain abundant $\mathrm{Al}$ and varying concentrations of $\mathrm{Si}$ and $\mathrm{S}$; Si occurs as coatings on spheres and prisms. X-ray diffraction of the white precipitate shows the presence of only three broad peaks that most closely correspond to the mineral sluminite, $\mathrm{Al}_{2}\left(\mathrm{SO}_{4}\right)(\mathrm{OH})_{4} \cdot 7 \mathrm{H}_{2} \mathrm{O}$.

Aluminite is one of several basic aluminum sulfates that form by the interaction of acid sulfate solutions, derived from the oxidation of pyrite, with marl or clay minerals at ambient temperatures. In the few localities where it has been positively identified, aluminite occurs as white chalky nodules composed of minute, well-formed prisms.

In a drain where neutrality is approached during the reaction between the Al-bearing acidic waters and $\mathrm{CaCO}_{3}$, perfect conditions are created for aluminite to crystallize in the weakly acidic solutions. The tendency of aluminite to form prisms and radiating spheres that interlock into a threedimensional network provides a quick path to pore-filling and drain failure.

\section{Afforestation-Induced Enhancement of Soil- Solution Aluminum and Manganese Concentrations in South African Highland Catchments}

\author{
NOWICKI, Tom and FEY, Martin V. \\ Dept. of Geological Sciences, University of Cape Town, \\ Rondebosch 7700, South Africa
}

The acidifying effect of tree plantations on soils is well documented but their impact on the composition of soil solutions and surface waters is less well understood. These impacts are being investigated in South Africa by comparing soils and waters of pine-afforested areas with those of adjacent grassland or fynbos scrubland. One key issue is the influence of afforestation on the mobility of metals, especially $\mathrm{Al}$ and $\mathrm{Mn}$. Monomeric $\mathrm{Al}$ and total $\mathrm{Mn}$ were determined in saturated paste extracts from bulk topsoil samples by colorimetry (chrome azurol method) and ion chromatography respectively. The extracts were also analyzed for $\mathrm{pH}$, electrical conductivity, major inorganic ions and dissolved organic carbon. Soil solution $\mathrm{Al}$ under forest mostly ranges from 0.5 to $2 \mathrm{mg} \mathrm{L}^{-1}$ and is enhanced 2 to 40 -fold relative to that in the adjacent virgin soil. There is a broad negative correlation between $\mathrm{pH}$ and $\mathrm{Al}$ concentration, with $6 \mathrm{mg} \mathrm{L}^{-1}$ and $10 \mathrm{mg} \mathrm{L}^{-1}$ being recorded in two very acidic $(\mathrm{pH}<4)$ forest soil solutions. In afforested catchments underlain by poorly buffered quartzitic rocks, elevated $\mathrm{Al}$ (up to $0.3 \mathrm{mg}$ $\mathrm{L}^{-1}$ ) was recorded in acidified stream waters. For the majority of soil solutions, Mn did not exceed $5 \mathrm{mg} \mathrm{L}^{-1}$ and in certain regions seldom exceeded $1 \mathrm{mg} \mathrm{L}^{-1}$. Nonetheless, several afforested soils showed significantly elevated soluble Mn levels, with values ranging up to $24 \mathrm{mg} \mathrm{L}^{-1}$. Mn concentrations did not correlate with solution $\mathrm{pH}$, possibly due to he greater influence of geologically governed enrichment, via weathering.
Mobilization and Attenuation of Metals Downstream of a Base-Metal Mining Site in the Mátra Mountains, Northeastern Hungary

ÓDOR, Lászlól, WANTY, Richard. B. ${ }^{2}$, HORVÁTH, István', FÜGEDI, Ubul'

'Hungarian Geological Survey, H-1143 Budapest, Stefánia u. 14, Hungary

${ }^{2}$ U.S. Geological Survey, M.S. 973 Denver Federal Center, Denver, CO 80225, USA

The Gyöngyösoroszi mine, approximately 75 kilometers northeast of Budapest, produced $\mathrm{Pb}, \mathrm{Zn}$, and minor $\mathrm{Cu}, \mathrm{Au}$, and $\mathrm{Ag}$ from several million tons of ore, since beginning operations in about 1949. At the site a flotation mill also operated, producing a fine-grained waste dump. Drainage from the mine, as well as breaches of the waste dumps, have spread mine wastes downstream towards the town of Gyöngyös. The extent of contamination has been documented by studies of stream-sediment chemistry from samples collected downstream of the mine in Toka and Száraz Creeks, and compared to a low-density survey of sediments from the entire country. From samples collected in the early 1990's, the water draining the mine has slightly acidic pH (_5.5) and relatively high concentrations of some dissolved metals ( $\mathrm{Fe}>10 \mathrm{mg} \mathrm{L}^{-1}, \mathrm{Mn}>5 \mathrm{mg} \mathrm{L}^{-1}, \mathrm{Zn}>10$ $\left.\mathrm{mg} \mathrm{L}^{-1}\right)$. Extremely low $\mathrm{pH}$ values are precluded by the carbonate minerals in the gangue, including calcite and dolomite. The weakly acidic $\mathrm{pH}$ values also may be attributed to a lack of availability of oxygen to oxidize pyrite remaining in the mine; the mine was closed in 1985 and has since remained undisturbed. In contrast to typical AMD from base-metal mines, concentrations of some metals are

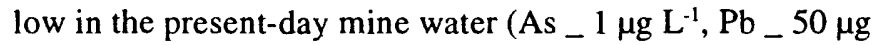
$\left.\mathrm{L}^{-1}, \mathrm{Cu}<10 \mu \mathrm{g} \mathrm{L}^{-1}\right)$. The metals concentrations in the mine water are further decreased by a lime-treatment process. This process, combined with dilution by creek waters and adsorption of metals to stream-sediment materials, leads to the relatively low dissolved metals concentrations observed downstream of the mine. Samples will be collected again in Spring, 1997, to augment our earlier results.

Based on the existing data, the primary mode of metals transport appears to be suspended loads associated with periodic flood events, an example of which is a layer of yellow sand which is chemically and mineralogically similar to the flotation dump material. The yellow sand layer is found in floodplain sediments near the town and at several other places, and is known to have been deposited as a result of breaches of the flotation dump. Even though transport of sediment material may be most important, transport of dissolved metals cannot be ruled out. Numerical modeling with PHREEQE shows that precipitation of trace-element minerals is not expected. Given the higher $\mathrm{pH}$ values in Toka Creek downstream of the mine, adsorption or dilution are suspected as the primary mechanisms for the observed decreases in metals concentrations downstream. 


\section{The Biogeochemistry of Sulfur in the Freshwater Florida Everglades-Sources, Cycling, and Relation to Mercury Methylation}

OREM, W.H., BATES, A.L., and LERCH, H.E.

U.S. Geological Survey, 956 National Center, Reston, VA 20192, USA

The Florida Everglades is threatened by a number of serious environmental problems, including contamination of fish and other wildlife with methyl mercury, and eutrophication of parts of the Everglades with excess phosphorus from agricultural runoff. Sulfur, primarily in the form of sulfate, is also entering the freshwater Everglades in concentrations that greatly exceed natural levels. In areas of the Everglades contaminated with excess phosphorus, sulfur is also accumulating. Sulfur accumulation rates vary from about $4,000 \mathrm{mg}$ $\mathrm{m}^{-2} \mathrm{a}^{-1}$ in phosphorus-contaminated areas to less than $500 \mathrm{mg}$ $\mathrm{m}^{-2} \mathrm{a}^{-1}$ in more pristine areas. The origin of the excess sulfur in eutrophied areas of the Everglades is unknown, but may enter the Everglades marshes from canal discharge as sulfate. Sulfur isotope results suggest a possible link to agricultural sulfur used as a soil amendment on sugarcane fields in the Everglades Agricultural Area (EAA). Sulfate discharged into the marshes diffuses into anaerobic marsh peats and is converted into sulfide by the metabolic activity of sulfate reducing bacteria. Sulfide concentrations in the pore water of Everglades peat range from $1,000 \mu \mathrm{g} \mathrm{kg}^{-1}$ in highly eutrophied areas, to 5 to $50 \mu \mathrm{g} \mathrm{kg}^{-1}$ in nominally contaminated areas, and undetectable $\left(<0.1 \mu \mathrm{g} \mathrm{kg}^{-1}\right)$ in highly pristine areas. Sulfate reducing bacteria are also considered to be largely responsible for the methylation of mercury in aquatic sediments. Thus, mercury contamination of Everglades' wildlife and sulfate discharge into the Everglades are linked environmental issues. This linkage, however, is complicated by several competing biogeochemical factors, including: (1) stimulation of sulfate reduction and methyl mercury production by sulfate, (2) immobilization of mercury in sediments as mercuric sulfide, and (3) other unknown environmental variables such as dissolved organic carbon concentrations and food web dynamics. Preliminary results suggest that the areas of the Everglades with highest methyl mercury production and bioaccumulation are those that receive only moderate input of sulfate from canal discharge. Further work is underway to refine the relationship between sulfate input to marshes and methyl mercury production.
Variations in Chemical and Bacterial Species of Acid Mine Drainage Affecting the Snow Fork Drainage Basin, Ohio-- The Esco \#40 Underground Mine

OVERLY, Bryan M. and LOPEZ, Dina L. Dept. of Geological Sciences, Ohio University, 316 Clippinger Laboratories, Athens, $\mathrm{OH} 45701$, USA

The Esco \#40 underground coal mine is a partially flooded, downdip drift mine located in Hocking County, Ohio, within the northern bituminous coal fields of the Appalachian Plateaus Region. Volumetric discharge of AMD ranges from 9.46 to $158 \mathrm{~L} \mathrm{~s}^{-1}$ and exceeds $94.6 \mathrm{~L} \mathrm{~s}^{-1} 55 \%$ of the year (Stachler, 1997). Variability of the water geochemistry, mineralogy, and bacteriology was ascertained in an effort to characterize relationships between the bacterial activity and physical and chemical properties of the effluent as it travels from the mine opening to the first point of confluence.

Water quality data collected from June 1996 to February 1997 indicate that the concentrations of dissolved constituents within the discharge are spatially and seasonably variable. Reductions in dissolved concentrations of Fe, $\mathrm{Mn}, \mathrm{Al}$, and sulfate $(42.5,42.3,4.01$, and $30.7 \%$, respectively), appear to be directly related to increased oxidation and mineral precipitation occurring amid the first $45 \mathrm{~m}$ of the flow path. Furthermore, these particular abiotic processes have been linked to biotic components such as transitory bacterial consortia. Three species of bacteria, Thiobacillus sp., Gallionella ferruginea, and Thiothrix sp. have been identified. Population distributions and spatial fluid flow regimes, in conjunction with mineral saturation indexes calculated via WATEQ4F, suggest that the presence of Thiothrix sp., a filamentous sulfur-oxidizer, is related to the precipitation of aluminum sulfates. This relationship is ascribed to Thiothrix's affinity for high fluid velocities. Variations in water chemistry, fluid velocity, and bacterial populations on other minerals precipitated along the flow path should be considered when developing remediation schemes.

\section{Hydrogeochemical Controls on Trace Element Release from the Penn Mine Base Metal Slag Dump, Calaveras County, California-Linking Field, Laboratory, and Geochemical Modeling Studies}

PARSONS, Michael B., EINAUDI, Marco, T., and BIRD, Dennis K. Department of Geological and Environmental Sciences, Stanford University, Stanford, CA 94305, USA

Slags from base metal smelters commonly contain high levels of potentially toxic elements (e.g., As, $\mathrm{Ba}, \mathrm{Cd}, \mathrm{Cr}, \mathrm{Cu}$, $\mathrm{Pb}, \mathrm{Zn}$ ). These slags have been widely used as construction materials, and, through leaching of trace elements, have contributed to extensive pollution of soils, surface waters, 
and ground waters. Previous studies of metal leaching from slags show poor correlation between laboratory test results and field data on the short- and long-term. We use field data, laboratory studies, and geochemical modeling to redict the stability of the Penn Mine slag dump, which is flooded annually by a drinking water reservoir and which may be in contact with acid ground waters from the adjacent mine property. Bulk ICP-AES analyses of 20 samples of granulated and monolithic slag show the following ranges in metal concentrations: $\mathrm{Zn} 0.03$ to $28.40 \mathrm{wt}$. \%, Cu 0.29 to 6.36 wt. $\%, \mathrm{~Pb} 0.02$ to 10.70 wt. $\%, \mathrm{Cd} 3$ to $14,100 \mathrm{mg} \mathrm{kg}^{-1}$, and As 3 to $9,210 \mathrm{mg} \mathrm{kg}^{-1}$. Mineralogical analyses of slag samples using EPMA and XRD have identified fayalite (average of $6.38 \mathrm{wt} . \% \mathrm{ZnO}$ ), willemite, gahnite, franklinite, magnetite, orthopyroxene, pyrite, pyrrhotite, sphalerite, chalcopyrite, cubanite, bornite, and covellite. Many slag samples also include lead- and barium-rich glass, and prills of copper matte. Leachates from TCLP extraction tests on two slags contain up to $2.53 \mathrm{mg} \mathrm{L}^{-1} \mathrm{Cd}$ and $29.90 \mathrm{mg} \mathrm{L}^{-1} \mathrm{~Pb}$. ICP-MS analyses of 31 filtered samples of lake water collected directly over the flooded slag dump reveal elevated concentrations of $\mathrm{Cd}\left(0.12-1.69 \mu \mathrm{L} \mathrm{L}^{-1}\right), \mathrm{Cu}(2.78-34.73 \mu \mathrm{g}$ $\left.\mathrm{L}^{-1}\right)$, and $\mathrm{Zn}\left(26.76-183.74 \mu \mathrm{g} \mathrm{L}^{-1}\right)$. These data confirm that high concentrations of potentially toxic elements do exist in the slag, and reveal dissolved metal concentrations in reservoir waters and TCLP leachates that exceed EPA mandated guidelines for the protection of aquatic life. Field data and results from laboratory leaching experiments are being incorporated into hydrogeochemical models to predict he results of reaction between the slag dump, lake waters, rain water, and acid ground waters from the mine.

\section{Vehicle Related Emissions of Heavy Metals and Platinum Group Elements in the Urban Environment- Examples from Birmingham, UK}

\author{
PEARCE, Nicholas J.G., BROTHWOOD, Susan J., FUGE, Ron \\ and PERKINS, William T. \\ Institute of Earth Studies, University of Wales, Aberystwyth, \\ Ceredigion, SY23 3DB, UK
}

Vehicles emit a variety of metals into the environment including $\mathrm{Pb}$ from petrol; $\mathrm{Ni}$ from diesel fuel; $\mathrm{Zn}$ and $\mathrm{Cd}$ from tires; $\mathrm{Cu}$ from brake linings and wiring; $\mathrm{Cr}$ from plating, and platinum group elements (PGEs, notably $\mathrm{Pt}, \mathrm{Pd}$ and $\mathrm{Rh}$ ) from catalytic converters. Urban dust and lichens have been collected from Birmingham City center and at sites on, and along traverses away from, the M6 motorway which carries approximately 80,000 vehicles per day. These have been analyzed by ICP-MS, following hot aqua regia digestion. Detection limits are approximately $10 \mu \mathrm{g} \mathrm{kg}^{-1}$ in the solid for PGEs, $\mathrm{Pb}, \mathrm{Cu}, \mathrm{Ni}, \mathrm{Cr}$ and about $40 \mu \mathrm{g} \mathrm{kg}^{-1}$ for in and $\mathrm{Cd}$. At all sites threshold limits for contaminated land (ICRCL, 1987) for $\mathrm{Pb}, \mathrm{Zn}, \mathrm{Cd}, \mathrm{Cu}$ and $\mathrm{Ni}$ are exceeded, with $\mathrm{Pb}$ exceeding $1,000 \mathrm{mg} \mathrm{kg}^{-1}$ in dust adjacent to the $\mathrm{M} 6$ and $6,000 \mathrm{mg} \mathrm{kg}^{-1}$ from Birmingham city center. PGEs show an exponential fall off in lichen along a 400-m traverse away from the M6, with Pd concentrations of about $700 \mu \mathrm{g} \mathrm{kg}^{-1}$ and $P t$ concentrations of about $70 \mu \mathrm{g} \mathrm{kg}^{-1}$ immediately adjacent to the motorway. Similar patterns are observed for $\mathrm{Pb}, \mathrm{Cu}, \mathrm{Cr}, \mathrm{Ni}, \mathrm{Zn}$ and $\mathrm{Cd}$. Roadside dust collected from the entrances and exits to Service Stations on the M6 showed the highest concentrations of PGEs, with Pt reaching $330 \mu \mathrm{g}$ $\mathrm{kg}^{-1}$, a result of higher engine stresses during acceleration.

\section{Behavior of Heavy Metals and REE in Acid Mine Drainage-Implications for the Behavior of Transuranic Metals}

\author{
PEARCE, Nicholas J.G., FUGE, Ron, PERKINS, William T. and \\ WHITE, Richard A. \\ Institute of Earth Studies, University of Wales, Aberystwyth, \\ Ceredigion, SY23 3DB, UK
}

Acidic drainage from abandoned mines carries high concentrations of dissolved solids. The UK has had a long history of metal and coal mining, which has left many abandoned mines and tips issuing acid waters, often highly contaminated with the $\mathrm{Pb}, \mathrm{Zn}, \mathrm{Cu}, \mathrm{As}, \mathrm{Cd}, \mathrm{Tl}, \mathrm{Bi}$ and $\mathrm{Hg}$. These elements may become concentrated into ochres (hydrous iron oxides) which precipitate as acid waters become neutralized and oxidized. $U$ and Th are also often present at high concentrations in many of these waters, and are preferentially concentrated into ochre.

In addition to high contents of toxic metals, high concentrations of lanthanides have been recorded in acid mine and tip drainage. Ce contents up to $115 \mu \mathrm{g} \mathrm{L}^{-1}$ have been recorded from Parys Mountain, Anglesey, in waters with $\mathrm{pH} 2.1$, whilst Ce contents from coal mine drainage in Lancashire ( $\mathrm{pH} \mathrm{8)}$ are below $0.03 \mu \mathrm{g} \mathrm{L}^{-1}$. A marked drop in REE concentration occurs between $\mathrm{pH} 2$ and $\mathrm{pH} 4.5$, with generally low concentrations being recorded above this $\mathrm{pH}$. Chondrite normalized REE patterns show MREE or LREE enrichment in waters, whilst NASC normalized patterns are generally MREE or HREE enriched, indicative of the increased solubility of M-HREE. Ochres precipitating from these waters have REE patterns which mirror the supernatant water, often being MREE enriched in NASC normalized plots. In general, ochres tend to concentrate REE more highly at higher $\mathrm{pH}$, with LREE being preferentially enriched some ten fold over HREE. In examples from metal mines in Cornwall and Wales, and coal mines from Lancashire, no marked anomalous partitioning of any REE is observed. This presentation will discuss the effects of $\mathrm{pH}$, increasing oxidation state and water chemistry on the partitioning of heavy metals and REE between waters and associated ochres. 


\section{Monitoring Marine Pollution and}

\section{Determining Palaeoclimate: The Application of Laser Ablation ICP-MS Studies to Marine Bivalve Mollusks}

\author{
PERKINS, William T., PEARCE, Nicholas J.G., TOLAND, Harry, \\ and FUGE, Ron \\ Institute of Earth Studies, University of Wales, Aberystwyth, \\ Ceredigion, SY23 3DB, UK
}

The shells of marine mollusks preserve a record of the environment in which the organism lived. This record contains information about the sea temperature ( $\mathrm{Mg}$ and $\mathrm{Sr}$ ) and the levels of certain marine pollutants $(\mathrm{Pb}, \mathrm{Cd}$ and $\mathrm{Cu})$. This paper presents the results of a high resolution laser ablation ICP-MS study on the shells of two modem bivalve mollusks- Arctica islandica (the Ocean Quahog or Iceland Suprina) and Cerastoderma (the cockle). These two species live in different environments and have very different longevity (Arctica up to 200 years; Cerastoderma up to 15 years). These differences are exploited in this study to provide different scales of time resolution for both the temperature and pollution records.

A high resolution laser ablation ICP-MS instrument, capable of sampling with a laser crater diameter of $\sim 20 \mu \mathrm{m}$, has been used to analyze modem shells collected from locations with well-characterized environmental conditions. The results of a pilot study which compares the $\mathrm{Mg}$ and $\mathrm{Sr}$ patterns of selected shells with the oxygen isotope record are presented. These data are used to 'calibrate' the trace element vs. temperature relationship and the potential application in palaeotemperature determination is illustrated. Pollutant metal distribution within modern shells will be presented and comparisons between a number of different settings will be made. We will discuss the use of marine bivalve mollusks as pollution monitors and discuss the potential of preserved fossil materials to provide a preanthropogenic "background."

\section{Determination Of Lead In Environmental Matrices By Hydride Generation Atomic Fluorescence Spectrometry (HGAFS)}

\author{
PING, Ren', and ZHOU, Liyi', GUO, Tao ${ }^{2}$ \\ 'Institute of Geophysical \& Geochemical Exploration, Langfang, \\ Hebei, 065000 China \\ ${ }^{2}$ Liaohe Oilfields Exploration \& Development Institute, Panjin, \\ Liaoning, 124010 China
}

Hydride generation technique in combination with atomic fluorescence spectrometry is a powerful method for determination of trace elements such as $\mathrm{As}, \mathrm{Sb}, \mathrm{Bi}, \mathrm{Se}, \mathrm{Te}, \mathrm{Ge}$, and $\mathrm{Pb}$. The recent invention of low temperature $\mathrm{Ar}-\mathrm{H}_{2}$ flame automatic ignition device and its introduction into the atomization system makes the original advantages of HGAFS even more significant, this also brings commercial success of XGY-1011 atomic fluorescence spectrometer, the newest product developed in our institute in 1995.

In this paper, $\mathrm{Pb}$ was determined in environmental matrices by HGAFS using the XGY-1011 atomic fluorescence spectrometer. The sample was first burned at $600{ }^{\circ} \mathrm{C}$ for five hours, then digested by $\mathrm{HNO}_{3}-\mathrm{HClO}_{4}-\mathrm{HF}-\mathrm{HCl}$ to evaporate and dryness, finally the residue was dissolved in hot water. The aqueous solution was acidified by $1.5 \% \mathrm{HCl}$ and generated $\mathrm{PbH}_{4}$ when mixed with $\mathrm{KBH}_{4}-\mathrm{K}_{3} \mathrm{Fe}(\mathrm{CN})_{6}-$ $\mathrm{NaOH}$. Using high intensity HCL lamp as exciting source, the detection limit obtained is $0.17 \mu \mathrm{g} \mathrm{L}^{-1}$ and the relative standard deviation (RSD) is $13 \%$ for $1 \mu \mathrm{g} \mathrm{L}^{-1} \mathrm{~Pb}$. Optimum conditions for hydride generation and determination were investigated. No interference of 39 elements of normal concentration level was evident using masking reagent. Simple aqueous standards were used for calibration purpose, and our determinations have good agreement with certified values in the analysis of national primary reference materials of vegetation (GSV-1, GSV-2, GSV-3) and human hair (GSH-l).

\section{Soil Chemical Patterns Possibly Linked to Mseleni Joint Disease Among Rural Inhabitants in Northern Kwazulu-Natal, South Africa}

POOLEY, Justin, FEY, Martin V., and WILLIS, James P. Department of Geological Sciences, University of Cape Town, Rondebosch, 7700, South Africa

Leached, infertile sands blanket the Mseleni area on this sub-tropical coastal plain, where there is an unusually high incidence of Mseleni Joint Disease (MJD) - a rare, crippling, osteo-arthritic condition - in a community which subsists largely on local food. Medical researchers suspect but have failed to identify a geochemical explanation. Soils were sampled along two transects through the area. The gray Fernwood sands were found to be moderately acidic (pH 5.8), with $<4 \%$ clay and $<1.5 \%$ organic C. Available Ca averaged 250, P 1.9, $\mathrm{Zn} \mathrm{0.4,} \mathrm{Cu} \mathrm{0.4,} \mathrm{B} 0.4$ and $\mathrm{Mn} 4.5$ $\mathrm{mg} \mathrm{kg}{ }^{-1}$, extracted with $\mathrm{NH}_{4} \mathrm{HCO}_{3}$-EDTA. Six-week maize (Zea mays) growth response to nutrient applications in pots of Fernwood sand confirmed the suboptimal supply of $\mathrm{Ca}, \mathrm{P}$, $\mathrm{Zn}, \mathrm{Cu}$ and $\mathrm{B}$, which was further confirmed by comparing foliar concentrations of these elements with norms for young maize. Foliar Se in ryegrass (Lolium multiflorum) grown in pots suggested sufficiency of this element. Fluoride in lake and borehole water was very low $\left(0.02-0.05 \mathrm{mg} \mathrm{L}^{-1}\right)$. Total analysis for a broad spectrum of elements ruled out the likelihood of toxicity. This first systematic geochemical study points to multiple elemental deficiencies. All the deficient elements have been associated in medical literature with skeletal disorders. Do they exert their influence synergistically? Local records suggest that MJD incidence is declining as the area develops and nutrition improves. The results may be relevant to an adjacent region in Mozambique. 


\section{Establishing Pre-Disturbance Water Quality Standards in Areas of Natural Acid-Metal Contamination-- Upper Alamosa River, Southern Colorado}

\author{
POSEY', Harry H., CAMPBELL ${ }^{2}$, Angus N., HANLEY', James E., \\ PENDLETON', James A., and WOODLING ${ }^{4}$, John \\ 'Department of Natural Resources, Division of Minerals and \\ Geology, 1313 Sherman St. Room 215, Denver, CO 80203, USA \\ ${ }^{2}$ Department of Public Health and Environment, Hazardous \\ Materials and Waste Management Division, 4300 Cherry Creek \\ Drive South, Denver, CO 80222, USA \\ ${ }^{3}$ U.S. Environmental Protection Agency, Office of Ecosystems \\ Protection, 999 I8th St. Suite 500, Denver, CO 80202, USA \\ + Department of Natural Resources; Division of Wildlife, 6060 \\ Broadway, Denver, CO, 80216, USA
}

"Use" designations were assigned to most water bodies in Colorado in the 1970's after federal and state clean water programs were enacted. "Designated uses" include aquatic life, drinking water, agriculture, and recreation. Water quality standards that protect aquatic life generally require lower concentrations of dissolved metals than other designated uses, so the aquatic life use designation protects most other lower uses. Commonly, water bodies were classified in the absence of definitive water chemistry data. Lacking such data, most perennial streams were assumed to be fisheries so were classified as such. Consequently, stream segments in some areas of natural contamination have standards more protective than the local natural conditions would indicate. Whereas industrial facilities that discharge process waters to naturally contaminated streams may consider the higher use standards overly stringent, environmental advocates tend toward the opposite view and may seek to retain even "inappropriately" attributed standards. In cases where public funds are used to restore sites to preindustrial conditions, these differences in interpretation may be more politically motivated than scientific. A three mile segment of the Alamosa River in southern Colorado carries enough natural contamination to suggest a less protective use designation than is currently in place. The segment between Alum Creek and Wightman Fork, upstream of the Summitville Superfund site, drains an area of intensive hydrothermal alteration with several percent pyrite. Rocks in this area decompose rapidly to a fine rock powder, producing a high surface area that enhances chemical weathering. Downstream of the altered area, values for $\mathrm{pH}$, $\mathrm{Cu}, \mathrm{Fe}, \mathrm{Mn}$ and $\mathrm{Zn}$ depart significantly from aquatic life standards during parts of the year, and $\mathrm{Al}$ concentrations are elevated during all parts of the year. These anomalous levels abate downstream as dilution from uncontaminated streams neutralizes the acid rock waters, but in the immediate area aquatic life is remarkably depauperate. Water quality standards should account for all natural conditions of streams. The Federal Clean Water goal of "fishable and swimmable" for all streams in the U.S. can be unrealistic in areas of naturally anomalous water compositions. Natural acid rock drainage can be reliably predicted in certain geological environments, and resultant anomalous metal concentrations should be provided for in the water quality standards.

\section{Identification and Characterization of Mine Effluent in Streams of the Colorado Mineral Belt- The Snake River, Montezuma Mining District}

\author{
PRIDE', Douglas E., FAURE', Gunter, and ROBINSON ${ }^{2}$, Charles \\ $S$. \\ 'Geological Sciences, Ohio State University, Columbus, $\mathrm{OH}$ \\ 43210, USA \\ ${ }^{2}$ Mineral Systems, Inc., Golden, CO 80401, USA
}

The quality of water in streams of the Colorado mineral belt is compromised by the presence of effluent emanating from abandoned mine workings and exposed waste rock. The challenge we confront is to make quantitative estimates of the abundance and chemical composition of this component within different streams. The purpose of our study was to provide information relevant to possible health effects and seek to determine the pre-mining quality of surface water in this area.

We are using the concentrations of the major conservative ions in the water of the Snake River to differentiate between ordinary ground water, water draining mineralized rock (mine effluent), and meteoric precipitation. The water in the river is a mixture of these three components whose abundances vary continuously along the channel. In the case of the Snake River, the abundance of mine effluent is most effectively determined from the concentrations of $\mathrm{Na}^{+}$and $\mathrm{SO}_{4}{ }^{2-}$ and decreases downstream from more than $15 \%$ to about $0.5 \%$ at the Dillon Reservoir, based on samples collected in late September of 1995 . The $\mathrm{pH}$ of the water rises from 3.75 to 7.40 in the same distance of $18 \mathrm{~km}$. The principal tributaries have a profound effect on the chemical composition of the water of the Snake River. The water of Deer Creek is characterized by high pH (7.5 to 8.0) and low concentrations of $\mathrm{Zn}^{2+}$ (about $25 \mu \mathrm{g} \mathrm{L}^{-1}$ ), whereas Peru Creek contributes water that is slightly more acidic $(\mathrm{pH}$ about 7.0), but has a high concentration of $\mathrm{Zn}^{2+}$ (about 1400 $\left.\mu \mathrm{g} \mathrm{L}^{-1}\right)$. Our work to date demonstrates that mine effluent in the Snake River is effectively diluted by surface runoff and that the changes in the concentrations of conservative ions are explainable in terms of three-component mixing.

\section{Geochemistry of Heavy Metals Derived from Sulfide Gold Minerals in the Marmato District, Colombia}

PRIETO, Gloria R.

INGEOMINAS - Diagonal 53 \# 34 - 53 Santafé de Bogotá, Colombia

Heavy metals $(\mathrm{Cu}, \mathrm{Pb}, \mathrm{Zn}, \mathrm{Cd}, \mathrm{Ag}, \mathrm{As}, \mathrm{Hg}, \mathrm{Sb}$, and $\mathrm{Bi}$ ) released during mining and processing of sulfide gold 
minerals from the Marmato District, were studied to determine their geochemistry, behavior and fate. Waters from Marmato carry dissolved metals ( $\mathrm{Zn}, \mathrm{Cd}, \mathrm{Cu}$, and $\mathrm{As}$ ). Waters from Marmato are unsuitable for drinking water, agriculture, aquatic life or industrial use. In sediments and particulate matter these metals show figures that range from $130-620 \mathrm{mg} \mathrm{L}^{-1}$ for $\mathrm{Cu} ; 330 \mathrm{mg} \mathrm{L}^{-1}-2.28 \%$ for $\mathrm{Pb} ; 1370 \mathrm{mg}$ $\mathrm{L}^{-1}-1.8 \%$ for $\mathrm{Zn} ; 7.6-200 \mathrm{mg} \mathrm{L}^{-1}$ for $\mathrm{Ag} ; 220-1850 \mathrm{mg} \mathrm{L}^{-1}$ for As; $6.8-56 \mathrm{mg} \mathrm{L}^{-1}$ for $\mathrm{Sb}$; $28-240 \mathrm{mg} \mathrm{L}^{-1}$ for Cd; $95-370$ $\mathrm{mg} \mathrm{L}^{-1}$ for $\mathrm{Hg}$ and $4-310 \mathrm{mg} \mathrm{L}^{-1}$ for $\mathrm{Bi}$. The highest values were found for the Marmato stream, while the Cauca River shows the lowest values, and the concentration of the metals in its sediments reflects the contents of its tributaries.

Chemical speciation shows that $\mathrm{Cd}, \mathrm{Zn}, \mathrm{Pb}$ and $\mathrm{Bi}$ have the highest bioavailability potential and show exchangeable fractions, while $\mathrm{Sb}$ and $\mathrm{Hg}$ do not have a mobile fraction and $\mathrm{Sb}$ is associated mainly with the residual fraction.

\section{Uptake of Trace Elements by Nutrient Plants from Soils Contaminated by Mining Activities in SW-Germany and North- Central Mexico}

\author{
PUCHELT, Harald, CASTRO, Javie, KURZ, Heidi and \\ MAISENBACHER, Peter \\ Institute for Petrography and Geochemistry, Kalsruhe University, \\ Hertz-Str. 16, Geb. 06.41, Kalsruhe, 76187, Germany \\ (harald.puchelt@rz.uni-karlsruhe.de)
}

On agricultural land in SW-Germany and North-Central Mexico which has been heavily polluted by mining, today wheat, corn, rape-seed and oats is grown. Because pollution is not homogeneously distributed over the area, there occur spots in the fields where growth is partially or totally prevented. Individual plants did not reach their full height and/or suffered from chlorosis. Many plants were analyzed for their concentrations of $\mathrm{Tl}, \mathrm{Cd}, \mathrm{Pb}$ and As in their stems, leaves and fruits, together with their parent soils, and some also for $\mathrm{Cu}, \mathrm{Ag}$ and $\mathrm{Ba}$, so transfer-factors for soil/plant could be calculated. The concentrations in the fruits were compared with the guidelines for foodstuff and their limits. Very few guideline values in nutrient plants exist for As. This paper gives some new values for As concentrations obtained by ICP-MS, INAA and FIAS-AAS. Interesting behavior was found for $\mathrm{Tl}$ in wheat. Its concentration is reduced at each node considerably, sometimes almost $50 \%$ in the upward direction. This suggests the existence of a special mechanism in these plants to reduce concentrations of trivalent $\mathrm{Tl}$. Testing for $\mathrm{K}$ in the same plants showed that there is no reduction in $\mathrm{K}$. The only difference between the two elements could be the different valence state $(K$ monovalent, $\mathrm{Tl}$ trivalent).

\section{Pesticide Adsorption onto Aquifer Sediments}

RAE, J.E., COOPER, C.S., PARKER, A., and PETERS, A. PRIS, The University of Reading, P.O. Box 227, Whiteknights, Reading, RG6 6AB, UK

Adsorption of pesticides onto soils has been extensively studied, but the extent of adsorption onto sediments and the processes operating are not well known. This study aims to: (1) determine the extent of adsorption of five pesticides (atrazine, simazine, diuron, linuron and isoproturon) and two degradation products (dichlorophenylurea and desethylatrazine) onto aquifer sands, and (2) explore the processes operating.

A core of Tertiary sands from the London Basin aquifer, UK, was studied and two approaches, both using batch experiments, were taken. Experiments were conducted in which: (1) the ionic strength of the solution remained constant and the adsorption results were correlated with the chemical and mineralogical properties of the sediment, and (2) the ionic strength of the solution was varied and adsorption results were compared to a simple thermodynamic calculation using partial molar free energies and a binding strength calculation.

$\mathrm{Kd}$ values were found to increase down-core (from $\sim 0.5-1$ in the uppermost $10 \mathrm{~m}$, to 25 and above from $10-20$ $\mathrm{m})$. For aquifer sediments it appears that, unlike soils, the organic carbon content of the solid phase is only one of several controls on pesticide sorption. In addition the ionic strength of the solution appears to be particularly significant, especially for low sorbate concentrations.

\section{The Response of the Interlayering of Clay Minerals to the Mobility of Aluminum in Acidified Podzols}

\author{
$R \ddot{A} I S A ̈ N E N, M . L$. \\ Geological Survey of Finland, Box 1237, 70211 Kuopio, Finland
}

The mobility of $\mathrm{Al}$ and interlayering properties of clay minerals were studied in podzolized tills near two industrial areas (a chemical pulp mill in central Finland and the $\mathrm{Ni}-\mathrm{Cu}$ smelters at Monchegorsk, Russia) and in their background areas. Elemental concentrations in the podzolic layers and parent tills were analyzed with hot aqua regia by using ICPAES. Species of Al were determined with several weak extraction methods by using AAS and ICP-AES. Clay minerals in the fine $(<40-50 \mu \mathrm{m})$ fraction were examined by XRD methods. All measurements were done at the Chemical and Mineralogical Laboratories of the Geological Survey of Finland. Throughout the profile, the predominant clay mineral was vermiculitic mixed-layer clay. As podzolization matures, the mixed-layer clay tends to alter to a smectite-like clay in the eluvial layer, while the illuvial layer is characterized by the presence of an Al-hydroxy interlayered vermiculite. Results from the Al speciation and XRD data of several 
profiles at polluted sites indicate that the increased mobility of $\mathrm{Al}$ results in the neochloritization of the swelling clay in the eluvial layer. In addition, Al precipitates were less stable in many profiles of the polluted sites than those formed luring long-term podzolization at background. It is concluded that anthropogenic acidification induces a partial outflowing of $\mathrm{Al}$, but also its reprecipitation in the soil. The source of $\mathrm{Al}$ is the partial decomposition of precipitates in the illuvial layer and in more acidified soils weathered feldspars in the eluvial layer.

\section{Biogeochemistry of Trace Elements in Plants and Soils Around Nasser Lake (Egypt)}

\section{RASHED, M.N.}

Chemistry Department, Faculty of Science, Aswan, Egypt

The trace elements $\mathrm{Ag}, \mathrm{Au}, \mathrm{Co}, \mathrm{Cr}, \mathrm{Cu}, \mathrm{Mn}, \mathrm{Ni}, \mathrm{Pb}, \mathrm{Sr}$ and $\mathrm{Zn}$ and the major elements $\mathrm{Ca}, \mathrm{Fe}, \mathrm{K}, \mathrm{Mg}$ and $\mathrm{Na}$ were determined in two native plant species (Tamarix nilotica and Astragalus vagellia) and the soils they were growing in, at depths of 10,30 and $60 \mathrm{~cm}$, at three sites of different geologic environments: Kalabsha and Garf Houssan (western side of Nasser Lake) and Allaqi (eastern side of the lake).

The results reveal that the accumulation and concentration of trace elements in plant material and from the soil solution differ from one another depending on the geologic terrane. Trace element concentrations in the plants differ depending on the selective uptake from soil by the two species.

Also, the results reveal that the soil on the western side of the lake contain high concentrations of $\mathrm{Na}, \mathrm{Ca}, \mathrm{Fe}, \mathrm{Cu}$, and $\mathrm{Sr}$ due to the presence of sedimentary rock rich with these elements. Soils of the eastern side of the lake contain high concentrations of $\mathrm{K}, \mathrm{Mg}, \mathrm{Cr}, \mathrm{Co}, \mathrm{Mn}, \mathrm{Pb}, \mathrm{Fe}, \mathrm{Ag}, \mathrm{Zn}$, and Au due to the presence of basement rocks rich in these elements.

\section{Emissions of Mercury to the Atmosphere: Natural Sources and Pathways}

\author{
RASMUSSEN, Pat E. ', McCLENAGHAN, M. Beth', SANGSTER, \\ Al L. ', EDWARDS, Grant C. ${ }^{2}$, and SCHROEDER, Bill H. ${ }^{3}$ \\ 'Geological Survey of Canada, 499-601 Booth St., Ottawa, \\ Ontario, Canada, KIA OE8; \\ ${ }^{2}$ School of Engineering, University of Guelph, Guelph, Ontario, \\ Canada, NIG 2WI \\ ${ }^{3}$ Atmospheric Environment Services, 4905 Dufferin St., \\ Downsview, Ontario, Canada, M3H 5 T4
}

Estimates of the global $\mathrm{Hg}$ flux from natural sources vary widely, partly due to a lack of temporally and spatially representative flux data and partly due to differences in underlying assumptions about the various sources and cycling processes at the earth's surface. A pilot study was conducted in the summer of 1996 near Clyde Forks, Ontario, Canada to develop methodologies for measuring atmospheric mercury fluxes from natural sources, to assess the relative influence of meteorological factors, soil conditions (moisture and temperature) and soil geochemistry, and to investigate the geochemical pathways through which $\mathrm{Hg}$ is liberated from bedrock to soil, vegetation and the atmosphere. At Clyde Forks, $\mathrm{Hg}$ is associated with tetrahedrite, chalcopyrite and pyrite mineralization within a 2-3 $\mathrm{m}$ thick inclined shear zone containing massive and disseminated barite hosted by Proterozoic metacarbonates. Mercury concentrations in B-horizon soil samples vary by 4 orders of magnitude over a short distance, from $1572 \mu \mathrm{g} \mathrm{g}^{-1}$ (s.d. 331) immediately above the mineralized shear zone to $0.14 \mu \mathrm{g} \mathrm{g}^{-1}$ (s.d. 0.04) at a baseline site $25 \mathrm{~m}$ away. Mercury fluxes monitored at four locations across the shear zone, using dynamic flux chamber techniques and a micrometeorological-gradient technique (all coupled with CVAFS detectors), also display extreme spatial and temporal variability, from daytime maxima of $>2.0 \mathrm{ng} \mathrm{m}^{-2} \mathrm{~s}^{-1}$ above the shear zone to nighttime minima of $1.0 \mathrm{pg} \mathrm{m}^{-2} \mathrm{~s}^{-1}$ at the baseline site. Ambient air $\mathrm{Hg}$ vapor concentrations inside a nearby abandoned adit also vary diurnally, typically between 400 and $600 \mathrm{ng} \mathrm{m}^{-3}$, despite the constant air temperature $\left(10^{\circ} \mathrm{C}\right)$ and relative humidity $(80 \%)$ inside the adit.

\section{The Influence of Mine-Drainage Formation on the Geochemical and Hydrogeological State of Environment in Estonia}

\author{
RÄTSEP, Aavo and LIBLIK, Valdo \\ North-East Estonian Department, Institute of Ecology, 15 Pargi \\ Str., EE 2045 Jõhvi, Estonia
}

Since the beginning of the use of Estonia's oil shale deposit, 860 million $t$ of oil shale has been mined. Direct effects of mining activities have become the main environmental problem in north-eastern Estonia. About 200-250 million $\mathrm{m}^{3}$ of water annually is pumped out of the mines and discharged directly to the surface water bodies. Modeling of water abundance shows $13-14 \mathrm{~m}^{3}$ per ton of excavated oil shale, and in the course of oil shale mining three stages of Ordovician aquifer systems have been partially or totally dewatered.

At the same time, the chemical composition of natural water changes from bicarbonate dominated to sulfatebicarbonate dominated with mineralization up to 1500-1700 $\mathrm{mg} \mathrm{L}^{-1}$. These geochemical processes are caused by the oxidation of pyrite which is present in the oil shale. The gypsiferous mine water in closed mines gives evidence of the longevity of mine water pollution. By hydrogeochemical investigations of the closed Kiviõli mine, the background levels of more important chemical constituents of mine water and the dynamics of their changes have been defined. Mine-drainage water influxes have damaged the selfregulation regime of the rivers changing their hydrochemical 
conditions: hardness is up to $16 \mathrm{mg}$-eq $\mathrm{L}^{-1}$, floating substances up to $200-250 \mathrm{mg} \mathrm{L}^{-1}$, the content of sulfates reaches $500 \mathrm{mg} \mathrm{L}^{-1}$. De-watering of mines causes the depletion of ground water the formation of a depression with and average depth $48 \mathrm{~m}$. As a result, in many areas the wells can no longer be used as water sources.

\section{An Investigation into the Mechanism by Which Synthetic Zeolite Amendments Reduce Soil Phytotoxicity}

\author{
REBEDEA', Irina, EDWARDS ${ }^{\prime}$, Robert, LEPP', Nicholas W., and \\ LOVELL ${ }^{2}$, Anthony \\ ${ }^{\prime}$ Liverpool John Moores University, Byrom Street, Liverpool, L3 \\ $3 A F, U K$. \\ ${ }^{2}$ Crossfield Chemicals, Warrington, Cheshire, UK
}

The addition of synthetic zeolites and similar materials to metal contaminated soils has been shown to reduce soil phytotoxicity and greatly improve the quality of the plant species grown on such amended soils ${ }^{1}$. To gain a clear understanding of the mechanism by which the phytotoxicity of contaminated soils is reduced when amended with synthetic zeolites, sequential extraction procedures have been used to identify changes associated with metal speciation in these amended soils.

Sequential extraction data are presented for three different contaminated soils which have been amended with synthetic zeolites ( $\mathrm{P}, 4 \mathrm{~A}$ and $\mathrm{Y}$ ) at different concentrations $\left(0.5,1\right.$ and $\left.5 \% \mathrm{w} \mathrm{w} \mathrm{w}^{-1}\right)$. The contaminated soils were collected from the site of a metal refinery, an old lead-zinc mine spoil tip and from a field which had been treated with sewage sludge. All sites were contaminated with elevated levels of toxic metals. After incubation for between one and three months the amended and unamended soils were leached with aqueous ammonium acetate. The results showed that there was a 30 to $70 \%$ reduction, depending on soil type, zeolite and percentage addition, in the metal concentration of the ammonium acetate fraction of soils which had been amended with the zeolites compared to the unamended soils. The mechanism by which zeolites reduce metal bioavailability in contaminated soils will be discussed and compared to other surface amendment treatments.

'Rebedea, I., Edwards, R., Lepp, N.W. and Lovell, A., 3rd International Conference on the Biogeochemistry of Trace Elements, Paris, 1995. "An investigation into the use of synthetic zeolites for in situ land reclama. tion".

\section{Environmental Impact of Phosphogypsum Use in Agriculture}

RECHCIGL, Jack E. and ALCORDO, Isabelo S.

University of Florida, IFAS, Research and Education Center, Ona, FL 33865, USA

Phosphogypsum $\left(\mathrm{CaSO}_{4}\right)$, a by-product of the manufacture of phosphoric acid, is a potential source of $\mathrm{S}$ and $\mathrm{Ca}$ for plants. Phosphogypsum contains low levels $(25$ to $30 \mathrm{pCi}$ $\mathrm{g}^{-1}$ ) of ${ }^{226} \mathrm{Ra}$ and its daughter products which could have detrimental effects on the environment. In Florida there are more than 600 million $\mathrm{Mg}$ of phosphogypsum stacked in waste piles with an additional 30 million $\mathrm{Mg}$ produced annually. This paper presents the results of field studies designed to evaluate the influence of phosphogypsum on forage yield and quality and its impact on soil and water quality, $\mathrm{Rn}$ surface flux and ambient atmospheric $\mathrm{Rn}$. Phosphogypsum application of up to $4.0 \mathrm{Mg} \mathrm{ha}^{-1} \mathrm{did}$ increase the quality and production of bahia grass forage. Phosphogypsum addition did not increase ${ }^{226} \mathrm{Ra},{ }^{210} \mathrm{~Pb}$ and ${ }^{210} \mathrm{Po}$ in soil or water and did not increase $\mathrm{Rn}$ surface flux, gamma radiation or $\mathrm{Rn}$ in the ambient atmosphere. This study has demonstrated that application of by-product phosphogypsum is a safe, economical and viable source of $\mathrm{Ca}$ and $\mathrm{S}$ for forage production.

\section{Lead and Zinc Contamination of Sediments in Zoar Vlei, Cape Peninsula, South Africa}

\author{
REID, Caroline, WILLIS, James P., and FEY, Martin V. \\ Department of Geological Sciences, University of Cape Town, \\ Rondebosch, 7700, South Africa
}

The sediments in Zoar Vlei, a natural water body contaminated with $\mathrm{Pb}$ and $\mathrm{Zn}$ from an adjacent residential and semiindustrial area of Cape Town, act as a strong sink for these elements. The concentrations of $\mathrm{Pb}$ and $\mathrm{Zn}$ in the sediments decrease away from the points of in-flow of surface run off. Sorption experiments showed that both $\mathrm{Zn}$ and $\mathrm{Pb}$ are sorbed by the sediments. The solubility of $\mathrm{Pb}$ and $\mathrm{Zn}$ entering the Vlei appears to be controlled initially by precipitation of $\mathrm{Pb}$ and $\mathrm{Zn}$ carbonate. However, once equilibrium is reached, sorption reactions are likely to exert a greater control on metal solubility. The sediments have a greater selective affinity for $\mathrm{Pb}$ than $\mathrm{Zn}$, and both $\mathrm{Pb}$ and $\mathrm{Zn}$ sorption are sparingly reversible. $\mathrm{Pb}$ can displace $\mathrm{Zn}$ from the sediments, but not vice versa. Acidification of Vlei water in equilibrium with the sediments caused $\mathrm{Zn}$ release. Theoretical speciation calculations using MINTEQA2 showed that $\mathrm{Zn}$ was present predominantly as $\mathrm{Zn}(\mathrm{OH})_{2(\text { aq })}$ and $\mathrm{Pb}$ as $\mathrm{Pb}\left(\mathrm{CO}_{3}\right)_{2}{ }^{2-}$ and $\mathrm{PbCO}_{3(\mathrm{aq})}$ species. The addition of $\mathrm{Pb}$ to Vlei water resulted in the precipitation of $\mathrm{PbCO}_{3}$. Under present environmental conditions the sediments act as a suitable filtering and storage facility for these elements, and prevent them from entering nearby Table Bay and the ocean. 


\section{The "Kola Ecogeochemistry" Project}

REIMANN, C. $, \ddot{A} Y R A ̈ S, M .^{2}$, CHEKUSHIN,.$^{3}$, BOGATYREV, I. , BOYD, R.', CARITAT, P. de ${ }^{l}$, FINNE, T.E. ${ }^{\prime}$, HALLERAKER, I.H.' , JAEGER, Ø.', KASHULINA, G. ${ }^{1.5}$, NISKAVAARA, H. ${ }^{2}$, PAVLOV, V. ${ }^{3}$, RÄISÄNEN, M.L. ${ }^{2}$ and VOLDEN, T. ${ }^{\prime}$

${ }^{\prime}$ Geological Survey of Norway, P.O. Box 3006, Lade, N-7002

Trondheim, Norway

${ }^{2}$ Geological Survey of Finland, P.O. Box 77, FIN-96101

Rovaniemi, Finland

${ }^{3}$ Kola Geological Information Laboratory Centre, Fersman st. 26, I84200 Apatity, Russia

${ }^{+}$Central Kola Expedition, Fersman st. 26, 184200 Apatity, Russia

${ }^{5}$ Kola Science Center, Institute of North Industrial Ecology

Problems, Fersman St. 14, 184200 Apatity, Russia, present address: '

The project "Kola Ecogeochemistry" was initiated in 1991, as a cooperation between Central Kola Expedition (CKE), Russia, the Geological Survey of Finland (GTK), and the Geological Survey of Norway (NGU). The project consists of a pilot project (1992), catchment studies (1994) and regional geochemical mapping (1995) and will finish with the production of a geochemical atlas of the project area at the end of 1996.

All the stages of the project have been carried out in the central parts of the Barents Region. This naturally sensitive part of Northern Europe encompasses some of the world's most strongly polluted places, but also areas almost untouched by human activity. These contrasts contribute to the rrea's fascination in a research context.

Multimedia (snow, terrestrial moss, humus, topsoil (0-5 $\mathrm{cm}$ ), mineral soil (C-horizon), stream water, stream sediment and overbank sediment) low density geochemical mapping was the approach chosen for the pilot project. In the catchment studies the same (and some additional) media were collected at a much higher density and frequency to guide the final selection of media for regional mapping and the interpretation of the results.

For the regional mapping stage terrestrial moss, topsoil (0-3 cm (heavy metals) and $0-5 \mathrm{~cm}$ (radionuclides)), lichen (predominantly from the Russian project area, for radionuclide determination only), complete Podzol profiles ( 5 layers) and lake water (Russian project area only) were collected during 1995 in a $188,000 \mathrm{~km}^{2}$ area at almost 650 sample sites. Analyses for about 40 elements were carried out using state of the art analytical techniques (ICP-MS, ICP-AES, CV-AAS, GF-AAS, XRF) to ensure today's lowest possible detection limits for all relevant elements. Results clearly show the heavy metal contamination around the Russian Ni-industry. In addition they highlight the importance of a thorough understanding of regional geology for the interpretation of the observed distribution patterns in all media collected.

A comprehensive description of the project with selected results is ccessible on the Internet at http/Awww.ngu.no/Kola).

\section{A Geochemical Atlas of the Central Parts of the Barents Region}

REIMANN, C. ${ }^{\prime}, \ddot{A} Y R \ddot{A} S, M{ }^{2}$, CHEKUSHIN,${ }^{3}{ }^{3}$, BOGATYREV,$I^{4}$, BOYD, R. ', CARITAT, P. de ${ }^{\prime}$, DUTTER, R. ${ }^{5}$, FINNE, T.E.', HALLERAKER, J.H.' , JAEGER, Ø.' , KASHULINA, G. ${ }^{1.6}$, LEHTO, $O .^{2}$, NISKAVAARA, H. ${ }^{2}$, PAVLOV,${ }^{3}$, RÄISÄNEN, M.L. ${ }^{2}$, STRAND, $T .^{7}$ and VOLDEN, T.'

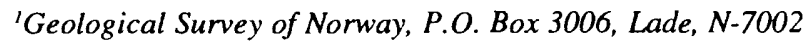

Trondheim, Norway

${ }^{2}$ Geological Survey of Finland, P.O. Box 77, FIN-96101

Rovaniemi, Finland

${ }^{3}$ Central Kola Expedition, Fersman St. 26, 184200 Apatity, Russia

${ }^{4}$ Kola Geological Information Laboratory Centre, Fersman st. 26, 184200 Apatity, Russia

'Institute of Technical Statistics, Technical University, Wiedner Hauptstr. 8-10, A-1040 Wien, Austria

${ }^{6}$ Kola Science Center, Institute of North Industrial Ecology Problems, Fersman St. 14, 184200 Apatity, Russia, present address: ${ }^{1}$

${ }^{7}$ Norwegian Radiation Protection Authority, P.O.Box 55, N-1345 $\emptyset$ sterås, Norway

The Central Kola Expedition (CKE), Russia, the Geological Survey of Finland (GTK) and the Geological Survey of Norway (NGU) cooperate since 1991 to produce an ecogeochemical atlas of the central parts of the Barents Region (http://www.ngu.no/Kola). This naturally sensitive part of Northern Europe encompasses some of the world's most strongly polluted places around the Russian nickel mining and smelting industry at Nikel, Zapoljarnij and Monchegorsk, but also areas almost untouched by human activity.

Regional sampling covered $188,000 \mathrm{~km}^{2}$ north of the Arctic Circle, comprising the entire area between $24^{\circ}$ and $35.5^{\circ} \mathrm{E}$, with the Barents Sea as the northern project border and the Polar Circle as the southern border. Just under 650 localities were sampled in the summer of 1995 , with the highest sample density close to the industrial centers and along the Norwegian-Russian border. Media collected for regional mapping were:

(1) Terrestrial moss (Hylocomium splendens or Pleurozium schreberi),

(2) Humus $(0-3 \mathrm{~cm})$ (for heavy metal analysis),

(3) Topsoil $(0-5 \mathrm{~cm})$ (for analysis of radionuclides),

(4) Reindeer lichen (at selected places only - for analysis of radionuclides),

(5) Complete Podzol profiles (5 horizons),

(6) Lake water (Russian project area only).

The atlas will present regional distribution maps for about 40 elements (Ag, $\mathrm{Al}, \mathrm{As}, \mathrm{B}, \mathrm{Ba}, \mathrm{Be}, \mathrm{Bi}, \mathrm{Ca}, \mathrm{Cd}, \mathrm{Co}, \mathrm{Cr}, \mathrm{Cu}$, $\mathrm{Fe}, \mathrm{Hg}, \mathrm{K}, \mathrm{La}, \mathrm{Mg}, \mathrm{Mn}, \mathrm{Mo}, \mathrm{Na}, \mathrm{Ni}, \mathrm{P}, \mathrm{Pb}, \mathrm{Rb}, \mathrm{S}, \mathrm{Sb}, \mathrm{Sc}$, $\mathrm{Se}, \mathrm{Si}, \mathrm{Sr}, \mathrm{Th}, \mathrm{Tl}, \mathrm{U}, \mathrm{V}, \mathrm{Y}$ and $\mathrm{Zn}$ ) analyzed with state-ofthe-art analytical techniques in an accredited laboratory guaranteeing very low detection limits. Color surface and black and white point source maps are prepared for four different media: moss, humus (topsoil $0-3 \mathrm{~cm}$ ) and Bhorizon and $\mathrm{C}$-horizon samples of the Podzol profiles. In addition the atlas will be accompanied by maps showing the distribution of radionuclides in topsoil $0-5 \mathrm{~cm}$. Base maps 
will include: general geology, Quaternary geology, mineral occurrences, industry, climate, topography and vegetation.

\section{An Integrated Environmental Geosciences Project in the Santa Cruz River Drainage Basin, Southern Arizona}

RIDLEY, W. I.', and, in alphabetical order, BERGER, B.R.', FINN, C.A. ', GETTINGS, M.E. ${ }^{2}$, HOUSER, B.B. ${ }^{2}$, KING, T.V.V.', LICHTE, F.E. ${ }^{\prime}$, SHANKS, W.C. III', WANTY, R.B.'

'U.S. Geological Survey, Box 25046, MS 973, Denver, CO 80225 , USA

${ }^{2}$ U.S. Geological Survey, SW Field Office, 520 N. Park Ave., Tucson, AZ 85719, USA

The Santa Cruz River Watershed is composed of several structurally-controlled aquifer systems, surrounded by heavily mineralized recharge regions, that provide water of variable quality for Tucson, Nogales, Green Valley and the burgeoning developments in the area. The recharge areas include several world-class porphyry copper systems, epithermal precious metal systems and base-metal skarn systems. The aquifer systems are fed by surface water and both shallow and deep ground water. The river system also sustains one of the richest, most diverse riparian habitats in the southwestern USA that is threatened by bioaccumulations of toxic metal contaminants and includes several endangered species and other proposed-endangered species. The objective of this interdisciplinary study is to provide new information and interpretations that enhance our understanding of the nature of, and factors that control, shallow and deep ground-water flow and quality within the watershed region; a critical aspect of future anthropogenic and environmental management of this important river system. The emphasis is upon the sources, transportation, and fate of potentially toxic cations and anions, and hence the risk of natural ground-water contamination, by mineralized ground. Consequently, the project involves studies within the various structurally-controlled geologic blocks that form the recharge regions and studies within the sedimentary fill of the Tucson, Santa Cruz and Sonoita Basins. The presentation will reflect the interdisciplinary nature of the project and will include current information on our studies in: structural and lithologic geology; major-, minor-, trace-element, and stable-isotope geochemistry and reaction path modeling; high-resolution airborne and ground gravity/magnetics; and high-resolution AVIRIS remotesensing.

Project Web Site: http://dodie.cr.usgs.gov/santa_cruz
Distribution of Trace and Major Elements in Surface Sediments from Coatzacoalcos River, Mexico

ROSALES-HOZ, L. and CARRANZA-EDWARDS, A. ICML, UNAM, Circuito Exterior Cd. Universitaria. Mexico D.F. 04510

Surface sediments collected during April 1994 in Coatzacoalcos River, Mexico, were studied for their trace and major element concentrations. The study area covers from the non-industrial area, to the lower reaches of the river, an area of great industrial development. Total and non-residual $(1 \mathrm{M} \mathrm{HCl})$ trace metals of $\mathrm{Cu}, \mathrm{Ni}, \mathrm{Cr}, \mathrm{Zn}$ and $\mathrm{Pb}$ show low concentrations similar to natural background values in the river highlands. Higher values of $\mathrm{Cu}, \mathrm{Cr}, \mathrm{Zn}$ and $\mathrm{Pb}$ were found at a specific site located in the lower reaches of the river with enrichment factors up to 1.31 for $\mathrm{Cr}, 4.57$ for $\mathrm{Cu}, 2.73$ for $\mathrm{Pb}$ and 1.78 for $\mathrm{Zn}$ compared to average soil. Values of $\mathrm{Cu}\left(141 \mathrm{mg} \mathrm{kg}^{-1}\right), \mathrm{Pb}(53.48 \mathrm{mg}$ $\left.\mathrm{kg}^{-1}\right)$ and $\mathrm{Zn}\left(152.7 \mathrm{mg} \mathrm{kg}^{-1}\right)$ are above the values usually present in soils. Through major element concentration the chemical index of alteration was evaluated showing differences among the high- and low-river reaches. An analysis was made of sediment characteristics (such as grain size, traction, saltation and suspension percentage) as they relate to metal concentrations. A significant correlation was found between trace metal concentrations and percentage of suspended grains.

\section{A Survey and Analyses of the $d^{18} \mathrm{O}$ and $\mathrm{d}^{13} \mathrm{C}$ Composition of Selected Shells from Core Tops at Five Locations in Florida Bay}

ROULIER, Leanne M. and HALLEY, Robert B. USGS Center for Coastal Geology, 600 4th St. South, St. Petersburg, FL 33701, USA

As an initial step in retrospective analysis of Florida Bay environments, we surveyed the $\mathrm{d}^{18} \mathrm{O}$ and $\mathrm{d}^{13} \mathrm{C}$ composition of 11 species of carbonate secreting organisms from the surface sediments of 5 different basins. Shells were selected from the top $10 \mathrm{~cm}$ of cores from near Long Key (LK), in Whipray Basin (WB), Buttonwood Sound (BS), Alligator Bay $(\mathrm{AB})$, and Long Sound (LS). These basins range.in location from near the western boundary to the eastern interior of the bay, respectively. The $\mathrm{d}^{18} \mathrm{O}$ and $\mathrm{d}^{13} \mathrm{C}$ composition of basin waters is controlled by factors influencing Florida Bay water quality and ecology such as salinity change (rainfall, evaporation, and runoff), temperature, bacterial respiration, and circulation which is reflected in the isotopic composition of these shells. Mudbanks divide the bay into sub-basins with partially isolated water masses, such that each sub-basin has distinctive water and isotopic characteristics.

Seven hundred and forty analyses for $\mathrm{d}^{18} \mathrm{O}$ and $\mathrm{d}^{13} \mathrm{C}$ were used to characterize these sites. $\mathrm{d}^{18} \mathrm{O}$ and $\mathrm{d}^{13} \mathrm{C}$ data 
from the interior basins ( $\mathrm{LS}, \mathrm{AB}, \mathrm{BS}$ ) show strong positive covariance reflecting increased fresh water input from the Everglades compared to little covariance near LK which is open to Atlantic Ocean waters. From near LK and LS, data sopulations exhibit mutually exclusive $\mathrm{d}^{13} \mathrm{C}$ values that compose end-member distributions. Progressively negative mean $\mathrm{d}^{13} \mathrm{C}$ values indicate a longer water residence time which allows the buildup of light carbon from the respiration of marine and terrestrial organic matter. Although there is overlap in mean $\mathrm{d}^{18} \mathrm{O}$ values in the intermediate sub-basins, they are significantly different from the more "normal marine" values maintained near LK. This study provides ground-truthing data for downcore interpretation of isotopic records for the last century in Florida Bay.

\section{Determination of Natural Background Concentrations of Dissolved Components in Water at Mining, Milling, and Smelting Sites}

\author{
RUNNELLS, Donald D.', DUPON, Daniel P. ', JONES, Richard \\ L. ${ }^{2}$, CLINE, David J. ${ }^{3}$ \\ 'Shepherd Miller, Inc., 3801 Automation Way, Suite 100, Fort \\ Collins, CO, 80525, USA \\ ${ }^{2}$ Kennecott Utah Copper Corporation, Combined Labs, P.O. Box \\ 6001, Magna, UT, 84044, USA \\ ${ }^{3}$ Kennecott Utah Copper Corporation, 10200 S. 8400 W., \\ Bingham Canyon, UT, 84006, USA
}

In order to establish meaningful remediation goals and monitoring programs in areas disturbed by mining and associated industries, it is desirable to determine the natural concentrations of metals that existed in the area prior to disturbance. In mineralized areas, multiple natural populations of metals and associated components may be present. This paper describes a method for characterizing natural background chemistry by means of probability distribution diagrams. The method can be applied to water, soil, and other natural materials. In a study of a complicated hydrogeologic system at the Kennecott Utah Copper North and South Operational Areas near Salt Lake City, Utah, probability distribution diagrams were used to differentiate between natural background waters and waters impacted by human activities. The probability distribution diagrams allowed a component-by-component interpretation of the chemistry of ground water and surface water over a large geographic area. Natural chemical background populations and anthropogenic effects were identified. Although the method is illustrated for mining-related sites, the same approach can also be used for other natural and anthropogenically impacted sites.

\section{A New Paleoclimate Indicator Based on AMS ${ }^{14} \mathrm{C}$ Dates of Biogenic Whewellite}

RUSS, Jon, and LOYD, David H.

Department of Chemistry, Newberry College, Newberry, SC 29108, USA

A natural rock crust composed primarily of the calcium oxalate mineral whewellite $\left(\mathrm{CaC}_{2} \mathrm{O}_{4} \mathrm{H}_{2} \mathrm{O}\right)$ is ubiquitous on limestone surfaces inside dry rock shelters and under rock overhangs throughout the Lower Pecos Region of southwestern Texas. The source of the whewellite is likely the lichen Aspicilia calcarea, based on micromorphological similarities between the crust and this lichen. The ubiquity of whewellite on surfaces that do not receive rain or runoff indicates the organism flourished in these microenvironments. Since $A$. calcarea is a xeric species, the maximum vitality of the organism-and the primary production of whewellitewould occur during dry climate regimes. During wet climate episodes the vitality of the lichen would be severely reduced due to a variety of physiological reasons including response to freezing water, an imbalance in water conditions that limits either the fungal or algal component of the lichen, and/ or inundation with water saturated with $\mathrm{Ca}$ and sulfate ions from the substrate. Thus, radiocarbon ages of the whewellite correspond to past xeric climate regimes, while periods in which no ${ }^{14} \mathrm{C}$ data occur correlate with mesic conditions. A preliminary paleoclimate reconstruction for the Lower Pecos, based on more than 25 AMS radiocarbon ages, generally agrees with other models established for Texas. Since whewellite is now realized to be common in rock surfaces, there is considerable potential that this method will have wide applicability.

\section{Environmental Geochemistry of Mercury Deposits in the Coast Range Mercury Belt, California}

\author{
RYTUBA, James $J$. \\ U.S. Geological Survey, MS 901, 345 Middlefield Road, Menlo \\ Park, CA 94025, USA
}

The Cenozoic CA mercury mineral belt extends for $400 \mathrm{~km}$ along the Coast Ranges of CA and consists of silicacarbonate and hot-spring-type mercury deposits. The silicacarbonate-mercury deposits formed early in the development of a slab window environment as the regional heat flow increased and resulted in widespread silica-carbonate alteration of serpentinite by low-temperature $\left(<120^{\circ} \mathrm{C}\right), \mathrm{CO}_{2}$ $\mathrm{CH}_{4}-\mathrm{H}_{2} \mathrm{~S}$-rich fluids. Hot-spring-type mercury deposits formed late in the evolution of the regional thermal anomaly from low-temperature, meteoric-dominated, hydrothermal fluids and have a trace metal association of $\mathrm{Li}, \mathrm{B}, \mathrm{As}, \mathrm{Sb}$, $\mathrm{Au}$, and W.

Environmental concerns include acid mine-drainage (AMD), and extremely high levels of $\mathrm{Hg}^{2+}$ (up to $200 \mu \mathrm{g} \mathrm{L}^{-1}$ ) and methylmercury (up to $70 \mathrm{ng} \mathrm{L}^{-1}$ ) in mine-drainage 
waters. In the northern part of the mercury belt where the ore deposits are the youngest, alkaline thermal waters and gas vents of $\mathrm{CO}_{2}$ naturally mitigate the AMD. Low to moderate total base metals (up to $110 \mathrm{mg} \mathrm{L}^{-1}$ ) in minedrainage waters reflect the low base metal contents of the ores. $\mathrm{Ni}$ in AMD is commonly very high (up to $100 \mathrm{mg} \mathrm{L}^{-1}$ ) and is derived from the serpentinite host rocks. Dissolved $\mathrm{Hg}^{2+}$ is derived from mercury oxy-sulfates and chlorides in mine tailings (calcines, having total $\mathrm{Hg}$ content of 0.2 to $1500 \mathrm{mg} \mathrm{kg}^{-1}$ ), and from the upper part of the ore zones, and from efflorescent salts. The extraordinarily high concentrations of dissolved methylmercury indicate that mercury mine-drainage waters provide an optimum environment for methylation of mercury because of their high sulfate and $\mathrm{Hg}^{2+}$ concentration and low $\mathrm{pH}$. Pyrite and marcasite are the primary acid generating sulfides in these deposits and comprise from 2 to 10 volume percent. High concentration of dissolved iron (up to $8800 \mathrm{mg} \mathrm{L}^{-1}$ ) leads to chemical precipitation of amorphous iron hydroxides that strongly sorb $\mathrm{Hg}$ (up to $110 \mu \mathrm{g} \mathrm{L}^{-1}$ ) and methylmercury (up to $110 \mathrm{ng}$ $\mathrm{L}^{-1}$ ) over the $\mathrm{pH}$ range of 2-7. Methylmercury sorbed on iron hydroxides in mercury mine-drainage waters is transported as suspended sediment during the first flood event into large aquatic systems where it causes methylmercury contamination of fish through the process of biomagnification.

\section{Laboratory Measurements of the Absorption and Oxidation of Sulfur Dioxide by Soil Surfaces}

\author{
SAKURAI, Yasuhiro, TAKAHASHI, Yoshiaki and MAKINO, \\ Tomoyuki \\ National Institute of Agro-Environmental Sciences, Tsukuba, \\ Japan
}

To forecast soil acidification caused by acid fallout in the future, it is necessary to accurately estimate the mass of acid materials loaded in the soil. Hitherto almost all of these forecasts have been based on the direct measurement of wet and dry fallout, excluding the loading of gaseous sulfur dioxide. Therefore, we have produced an apparatus for the measurement of sulfur dioxide absorption/oxidation at the soil surface under aerated conditions. We have measured the sorbed sulfur dioxide using synthesized zeolites and different Japanese soils. This apparatus consists of a cylinder of standard sulfur dioxide gas, an air-compressor, a gas flow meter, an air humidity regulator, a gas mixer, a temperature regulator, and a vessel for the reaction. The latter enables to gases used in the reaction to regulate their concentration, flow rate, temperature, and relative humidity. Deviations in the concentration of sulfur dioxide in the vessel are less than or equal to $3 \%$, and the mass absorbed is proportional to exposure time.

We obtained the following results through experiments using this apparatus; (1) there exists a low correlation between the mass of sorbed sulfur dioxide and the specific surface area of synthesized zeolites; (2) the sulfur dioxide absorption takes place on the surface of samples-- the higher the relative humidity the greater the sulfur dioxide sorbed; (3) in each of the different soils, the order of sorbed mass of sulfur dioxide was different. The mass of sulfate ion sorbed on each soil type at standard atmospheric concentration (10 $\mathrm{ppb}$ ) is estimated to be $0.9-2.8 \mathrm{~g} \mathrm{~m}^{-2} \mathrm{a}^{-1}$.

\section{Low-Water Sediment in Rivers of Belarus: Origin, Mineralogical and Geochemical Composition, Potential Use For Environmental Assessment}

\author{
SAVCHENKO, Vladimir, TANOVITSKAY, Nina, and \\ SAMSONENKO, Igor \\ Institute for Problems of Natural Resources Utilization and \\ Ecology, Belarussian Academy of Science, Staroborisovsky tract, \\ 10, 220114, Minsk, Belarus
}

Low-water sediment is a thin layer of bottom sediment deposited in river shallows when water discharge is minimal and low-water periods occur in the river system. Natural features of the low-water sediment composition are illustrated by an example of a $90-\mathrm{km}$ long section of the Berezina River draining the Berezinian Biosphere Reserve. The data obtained have been compared with those available from routine sampled bottom sediments and 2 types of overbank sediments ("old" - humic horizon of floodplain soil and recent overbank sediments sampled from the surface of the floodplain soil immediately after floods caused by heavy summer rains). The investigation has shown that the lowwater sediment holds a special place among recent alluvial sediments in origin, mineralogy and chemical composition. The data obtained may be used as the geochemical background values for landscapes of Belarus.

The use of low-water sediment allows a considerable expansion of the temporal and spatial applications of geochemical control and monitoring: geochemical anomalies recognized as a result of the low-water sediment analysis are more extended and well differentiated; and show a greater contrast and persistence of anomalous metals. It can be used for the determination of background levels of elements, for distinguishing geogenic and anthropogenic anomalies, and for the estimation of the degree of pollution and for monitoring.

The geochemical maps for most of the 35 analyzed elements were produced on the basis of the chemical analyses and statistical data treatment. Most of known and some unknown sediment anomalies in rivers of Belarus were detected with anomalous metal concentrations in low-water sediment and showed better contrast and homogeneity. The similar pattern of distribution was revealed for ${ }^{137} \mathrm{Cs}$ in alluvial sediments of the river valley contaminated by Chernobyl radionuclides. Low-water sediment is suggested as a new suitable and convenient medium for geochemical exploration. 


\section{Trace Element Distribution in Soils and} Factors Affecting Metal Uptake By Plants in the Contaminated Floodplain of the Svisloch

\section{River, Belarus.}

SAVCHENKO, Vladimir', and GOLOVATIY, Sergei ${ }^{2}$

'Institute for Problems of Natural Resources Utilization and Ecology, Belarussian Academy of Sciences, Staroborisovsky tract, 10, 220114, Minsk, Belarus

${ }^{2}$ Belarussian Research Institute for Soil Science and Agrochemistry, Belarussian Academy of Agricultural Sciences, Kazinets st., 62, 220108, Minsk, Belarus

The 140-km section of the Svisloch River located in the central part of Belarus is severely polluted by $\mathrm{Cr}, \mathrm{Ni}, \mathrm{Cu}, \mathrm{Zn}$, $\mathrm{Ag}, \mathrm{Sn}, \mathrm{Pb}, \mathrm{Mo}, \mathrm{Cd}$, and $\mathrm{Ba}$ caused by Minsk's sewage discharge. The river floods annually and so the floodplain is also polluted. The association of contaminants in bottom sediments and alluvial soils is identical, but differs in the contrast of anomaly, mode of metal occurrence, and decay pattern. Exchangeable metal compounds dominate in the floodplain sediment anomaly.

The lateral distribution of anomalous metals across the floodplain varies considerably depending on a number of factors, including the nature of the primary anthropogenic source, the previous dispersion history of the anomalous constituents, the geomorphological level, the distance from the river bed and local conditions. There are principal differences in the distribution of anomalous elements setween 3 floodplain facies: natural levee, middle part and wetland part near terraces.

The vertical distribution also is not homogeneous. A stepwise decrease in the concentrations of $\mathrm{Cr}, \mathrm{Cu}, \mathrm{Zn}, \mathrm{Ni}$, $\mathrm{Sn}, \mathrm{Ag}$, and Mo from the top layer to the lowest layer may be explained by recent intensity of pollution ( $40-50$ years) and effects of a biogeochemical barrier. According to the study, this effect increases as much as 3 times in comparison with that in uncontaminated soils.

By examining the element distribution in pasture vegetation, and the enrichment factors with respect to background and plant/soil ratios, it is possible to divide elements into two different groups: essential (biophile) metals - $\mathrm{Cu}, \mathrm{Zn}, \mathrm{Mo}, \mathrm{V}$; and non-essential - Ni, Cr, Pb, Sn. The importance of several soil parameters (total concentrations in soils, metal concentrations in the exchangeable fraction, soil $\mathrm{pH}$, cation exchange capacity, the presence of other interacting elements, content of organic matter) in relation to metal bioavailability is discussed.

The correlation between the metal concentrations in the cow (milk and excrement) and other parts of the floodplain environment will be assessed

\section{Some Approaches to the Biogeochemical Study of Contaminated River Ecosystems}

\section{SAVCHENKO, Vladimir}

Institute for Problems of Natural Resources Utilization and

Ecology, Belarussian Academy of Sciences, Staroborisovsky tract, 10, 220114, Minsk, Belarus

The method proven to be efficient for assessment and monitoring the aquatic environment is biogeochemistry. The investigation of heavy metal and radionuclide distribution in contaminated and uncontaminated river ecosystems was carried out according to the three levels of the biosphere structure: biocenosis, species and organism.

The first level was represented by the following food chain: stream sediment - dissolved and suspended phases of river water - aquatic plants - bryozoans - mollusk - frog fish - duck -semiaquatic mammals (American mink, muskrat, beaver). For natural uncontaminated river ecosystems, heavy metals were found to accumulate in species in higher levels of the food chain. Conversely, for contaminated river a non-accumulation capacity of food chain with respect to metals was revealed.

The second level - the bioavailability, uptake and storage of heavy metals in 12 species of aquatic plants (bottom of the food chain) and 3 species of semiaquatic mammals (top of the food chain) were assessed.

Bioaccumulation capacity of aquatic macrophytes depends on belonging to a particular ecological group (submerged floating unattached - floating attached - emergent) rather than variation in species sensitivity to metals. Priority indicators of metal contamination are listed.

The third level - the distribution of 10 metals, ${ }^{137} \mathrm{Cs}$ and ${ }^{134} \mathrm{Cs}$ in organisms (muscle, liver, kidney, blood, bone, skin with hair, bowel content, anus gland) of American mink, otter, beaver and muskrat were examined. Trace metal speciation in the organism of semiaquatic mammals is considered with regard to the problem of biomonitoring. There are significant differences in metal uptake by living organisms between 2 groups of anomalous elements: essential (biophile) metals - $\mathrm{Cu}, \mathrm{Zn}, \mathrm{Mo}, \mathrm{V}$; and nonessential - $\mathrm{Ni}, \mathrm{Cr}, \mathrm{Pb}, \mathrm{Sn}$. The concentration level in biota of non-essential elements is much greater, although the similar anomaly contrasts of essential and non-essential metals in water and bottom sediment are observed. The differences are revealed for 3 levels of the biosphere structure.

The list of bioindicators and the program of monitoring the aquatic environment are discussed. The application of several coefficients for estimating the degree of contamination is demonstrated. 


\section{Emissions of Platinum-Group-Elements (PGE) from Automobile Catalytic Converters in Soils Along Highways}

\author{
SCHAEFER, Joerg and PUCHELT, Harald \\ Institute fur Petrography and Geochemistry, Karlsruhe University, \\ Hertz-Str. 16, Geb. 06.41, 76187 Karlsruhe, Germany \\ (dg16@rz.uni-karlsruhe.de)
}

The increasing use of catalytic converters containing platinum-group-elements (PGE) such as $\mathrm{Pt}, \mathrm{Rh}$ and $\mathrm{Pd}$ in automobiles has led to significant emissions of these noble metals in soils along highways. Platinum contents in upper soil (0-2 cm depth) next to traffic lanes vary from several hundred $\mu \mathrm{g} \mathrm{kg}^{-1}$ to local background values that are mostly reached at a distance of less than $20 \mathrm{~m}$. Maximum Pd and $\mathrm{Rh}$ contents in soils were found to be about 10 and $30 \mu \mathrm{g}$ $\mathrm{kg}^{-1}$ respectively so they by far exceed natural concentrations which are in the low $\mu \mathrm{g} \mathrm{kg}^{-1}$-range. Soils from southwestGermany, on Quaternary sediments, show geochemical PGE background values of up to $4 \mu \mathrm{g} \mathrm{kg}^{-1}$; in soils over some basaltic rocks and volcanic formations these levels are even lower.

Lateral distribution patterns of PGE with distance to the traffic lane are similar to those of other automobile-emitted elements such as $\mathrm{Pb}, \mathrm{Zn}$ and $\mathrm{Cu}$. Traffic-related PGE contents show a strong decrease with depth while the maximum contents of the other traffic-related and more abundant heavy metals occur in the depth range of $2-5 \mathrm{~cm}$. A significant correlation of $\mathrm{Pt}$ and $\mathrm{Rh}$ is described by a characteristic ratio of roughly $6: 1$ reflecting the application of these elements in the most commonly used converters. The Pt/Rh-ratio increases when PGE contents approach natural background values.

These investigations were made in cooperation with the Landesanstalt für Umweltschutz (LfU) Baden-Württemberg with financial support by the Projekt Wasser-Abfall-Boden (PWAB).

\section{Lead Isotope Anomalies in Maar Lake Sediments - Indications for Extensive Lead Mining in the Northwestern Eifel (Germany) During the Time of the Roman Empire}

SCHETTLER, Georg and ROMER, Rolf L.

GeoForschungsZentrum Potsdam, Telegrafenberg, D-14473

Potsdam, Germany

Annually laminated sediments from two Quaternary Maar lakes in the Western Eifel volcanic field (Germany) show Pb anomalies within sections deposited during the first centuries $\mathrm{AD}$ that exceed the local geological background 8.5-fold in Lake Meerfelder Maar (MFM) and 4-fold in Lake Schalkenmehrener Maar (SMM). These $\mathrm{Pb}$ anomalies are associated with a distinct shift in the $\mathrm{Pb}$ isotope signature to a less radiogenic composition.

The $\mathrm{Pb}$ isotope ratios of the local mineral input into the Maar Lakes are: ${ }^{206} \mathrm{~Pb} /{ }^{204} \mathrm{~Pb} \sim 18.91 \pm .02,{ }^{207} \mathrm{~Pb} /{ }^{204} \mathrm{~Pb}$ $\sim 15.69 \pm .02$, and ${ }^{208} \mathrm{~Pb} / 204 \mathrm{~Pb} \sim 39.11 \pm .03$. The isotopic composition of the excess $\mathrm{Pb}$ component is estimated using mass balance and the $\mathrm{Pb}$ isotopic signature of the local geogenic background to be ${ }^{206} \mathrm{~Pb} /{ }^{04} \mathrm{~Pb} \sim 18.37 \pm .02,{ }^{207} \mathrm{~Pb} /$ ${ }^{204} \mathrm{~Pb} \sim 15.66 \pm .02$, and ${ }^{208} \mathrm{~Pb} /{ }^{204} \mathrm{~Pb} \sim 38.48 \pm .03$. The excess $\mathrm{Pb}$ has the same isotopic composition as galena deposits 60 $\mathrm{km}$ to the NW of the Maar lakes. It was transported via air into the Maar lakes and originates from Roman $\mathrm{Pb}$ refinement and Ag cupellation that is documented by rare archaeological finds in the Northwestern Eifel. Varve

chronostratigraphy of correlated cores indicates that Roman $\mathrm{Pb}$ input was significant for about 230 years. The Roman $\mathrm{Pb}$ anomaly represents a sharp time marker that allows the correlation of lacustrine records of different lakes on a regional scale.

\section{Lacustrine Records of Heavy Metal Pollution-Problems of Dating}

\author{
SCHETTLER, Georg \\ GeoForschungsZentrum Potsdam, 14473 Potsdam, \\ Telegrafenberg, Germany
}

The sensitivity of sediment records to anthropogenic heavy metal pollution is demonstrated for three different European Lakes (Lake Breitling, Lake Meerfelder Maar, Western Eifel Volcanic field, Germany and Lago Grande di Montichio, Southern Italy). A general increase of the airborne deposit of volatile elements $(\mathrm{Cd}, \mathrm{Zn}, \mathrm{Pb}, \mathrm{Se})$ due to increased burning of fossil fuels is found even at relatively unpolluted sites. It is often uncritically accepted that it reflects the spread of industries since the end of the last century. The obtained increase of heavy metal contents in modern surficial sediments itself is used as a good opportunity to correlate core sites. Therefore, correct dating of heavy metal increase has obtained more attention recently.

The measurement of ${ }^{137} \mathrm{Cs}$ - and ${ }^{210} \mathrm{~Pb}$-profiles is the most powerful tool for dating of young sediments without annual lamination. However, we have often gotten unexpected or even contradictory results. Beside early diagenetic mobility of heavy metals and acidification of the catchments, radiogenic dating itself was critically checked as a possible reason: the Chernobyl accident at the end of April 1986 caused the introduction of radionuclides into European freshwater lakes. The relatively high deposition of the longlived ${ }^{137} \mathrm{Cs}\left(\mathrm{T}_{1 / 2}=30\right.$ years) gives a time marker for the more recent sedimentation history. However, distribution coefficients $\left(\mathrm{Kd}=\left[\mathrm{Cs}_{\mathrm{s}}\right] /\left[\mathrm{Cs}_{1}\right]\right)$ are found to be low in organic sediments. Sediment profiles of ${ }^{137} \mathrm{Cs}$ were numerically simulated for various $\mathrm{Kd}$-values and different sediment accumulation rates within a closed lake system. The simulations indicate that the ${ }^{137} \mathrm{Cs}$-maximum can give inaccurate sedimentation rates. In general, sediment accumulation is estimated too high when sediment profiles were recovered only a few years after the Chernobyl event but too low when sampling was carried out later. 
Stable Isotope Characteristics of Waters Draining Massive Sulfide Deposits in the Eastern United States

SEAL, Robert R., II, and WANDLESS, Gregory A. U.S. Geological Survey, 954 National Center, Reston, VA 20192, USA

Oxygen, hydrogen, and sulfur isotope compositions of surface and ground waters and sulfide minerals from an unmined massive sulfide deposit (Maine) and abandoned massive sulfide mines (Virginia and North Carolina) are used to (1) place constraints on primary and secondary geochemical processes that affect the isotopic signatures of sulfide oxidation and acid generation, and (2) distinguish deposit-related dissolved sulfate signatures from local baselines. The $\mathrm{pH}$ and sulfate concentration of point-source and background waters range from 2.7 to 8.1 , and from 25 to $1705 \mathrm{mg} \mathrm{L}^{-1}$, respectively. The $\mathrm{d}^{34} \mathrm{~S}$ values of ore sulfide and dissolved sulfate are indistinguishable from one another in Maine and Virginia and suggest that following initial sulfide oxidation, there was no subsequent bacteriallymediated sulfate reduction. In North Carolina, the $\mathrm{d}^{34} \mathrm{~S}$ values of dissolved sulfate are higher than those for ore sulfides and may indicate bacterially-mediated sulfate reduction. In Maine, even though the $\mathrm{d}^{34} \mathrm{~S}$ values of depositrelated and background waters are indistinguishable, an anomalously high $\mathrm{d}^{18} \mathrm{O}$ value of background sulfate $(9.2 \%$ ) suggests significant contributions of sulfate from atmospheric sources. The $\mathrm{dD}$ and $\mathrm{d}^{18} \mathrm{O}$ values of the waters conform to the meteoric water line except for stagnant seeps which lie to the right and at more positive values relative to local meteoric water, consistent with evaporation. The $\mathrm{D}^{18} \mathrm{O}$ $\left(\mathrm{SO}_{4}{ }^{2-}-\mathrm{H}_{2} \mathrm{O}\right)$ values range from 3.1 to $16.6 \%$ and reflect diverse environments of sulfide oxidation ranging from submersed, sterile, anaerobic conditions to aerobic conditions above the water table. The data also demonstrate that the primary isotopic signatures of sulfide oxidation can be obscured by secondary processes such as evaporation or dissolution of secondary salts in local settings.

\section{Integrating GIS and Multivariate Statistics in Environmental Geochemistry}

\author{
SELINUS, Olle and ZHANG, Chaosheng ${ }^{2}$ \\ 'Geological Survey of Sweden, P.O. Box 670, 75128 Uppsala, \\ Sweden \\ ${ }^{2}$ Institute of Geography, Chinese Academy of Sciences, Beijing \\ 100101, China
}

In Sweden, geochemical mapping is carried out with specialized methods that allow the data to be used in environmental research, including sampling plant roots and nosses from streams, soils and bedrock. These three sample -ypes form an integrated strategy in environmental research. One problem that is prominent is to distinguish the signals derived from natural sources from those derived from anthropogenic sources.
Bedrock geochemistry from different lithologies in a major region of southern Sweden (which is a rather densely populated region with different sources of pollution) is analyzed together with stream or soil data. By modeling the partial least square (PLS) regression between these data sets separate multivariate geochemical models based on different bedrock types are developed and these calibrated models can subsequently be used for predicting new geochemical samples. Information is obtained on how much of the metal contents in each new geochemical sample correlate with the different modeled bedrock types. By computing the appropriate residuals, we obtain information on the anthropogenic impact that is also carried by new samples. The data are combined with other data in the present research using the analytical capabilities of GIS.

ARC/INFO coverages have been created of bedrock geology, soil geology, biogeochemistry, soil geochemistry, bedrock geochemistry, data on environmental pollution into air and water, radiation data, metal contents in wild animals, incidence data for child diabetes and child leukemia as well as background/anthropogenic data derived from the above mentioned analysis.

We have also investigated the natural levels of metals in contrast to the anthropogenic levels in order to ensure certain connections between the natural background levels with certain diseases supposed to be caused by elevated contents of heavy metals.

\section{Differentiation of Heavy Metals as a Reflection of Landscape-Use Levels}

\author{
SEMENOV, Yury M., SEMENOVA, Lyudmila N. \\ Institute of Geography SD RAS, Ulanbatorskaya St. 1, Irkutsk \\ 664033, Russia
}

Creation of user-friendly optimization programs is directed to a search of means and methods of promoting the more complete realization of natural-resource potential in order to receive maximum productivity of geosystems under conditions of environmental protection and even environmental improvement. The establishment of optimal landscape-use levels is presented by revealing the fact of either correspondence or lack of correspondence between modern features of economic use, extent of technogenic loads, and spatial differentiation of a particular territory's natural potential. The differentiation of heavy metals in taiga, subtaiga, foreststeppe, and steppe ecosystems in southern Middle Siberia were studied as reflect of modern environmental state and landscape-use levels. Our investigations included stationed based studies of landscape-geochemical regimes, scales of technogenic substance input, changes of chemical composition of ecosystem components under anthropogenic influence, and interrelations between factory functioning and landscapes exposed to a technogenic impact.

Content levels of $\mathrm{Ti}, \mathrm{Mn}, \mathrm{Ba}, \mathrm{Sr}, \mathrm{Cr}, \mathrm{V}, \mathrm{Ni}, \mathrm{Cu}, \mathrm{Co}, \mathrm{Pb}$ within ecosystem components and technogenic products were established, the trends of anthropogenic transformation of trace element composition in soils, natural waters, and 
plants of South-Eastern Zabaikalye, Pribaikalye, Nazarovo and South Minusinsk intermountain hollows were revealed. Ecological geochemical zoning has been conducted for the territories of KAFEC (Kansk-Achinsk fuel-lignite complex in southern part of Nayarovo hollow) top-priority objects and the Sayansk aluminum plant's (South Minusinsk hollow) influence according to summary technogenic impact with heavy metals. The forecasting heavy metals' behavior was elaborated for soils under pollution by technogenic products on the basis of natural and technogenic substance flow's experimental modeling. The standardization of technogenic loading levels was conducted for steppe and forest-steppe ecosystems using contents of trace elements. These research results can serve as basic data for environmental geochemical monitoring.

This work was carried out with financial support from the Russian Foundation of Fundamental Research (project code 96-05-65978).

\section{Heavy Metals as Indicators of Antropogenic Pollution of Bottom Sediments in Neva Bay}

\section{SHAKHVERDOV V.}

All-Russian Geological Institute (VSEGEI) 4, Sredniy pr., St. Petersburg, I99026 RUSSIA

Every year hundred tonnes of iron, tens of tonnes of lead, zinc and other metals are transported to Neva Bay. These pollutants accumulate and remain in the modern bottom sediments, making it possible to observe short-term and irregular variations in their loadings, and in some cases to establish a sources of the pollution. The study of heavymetal distribution in the modern bottom sediments of Neva Bay enables regional geochemical background characterizations, allows us to distinguish natural components of a regional geochemical zonality and to show zones of geochemical background variation as a result of anthropogenic influence. Modern technogenic geochemical anomalies are distinct from the natural geochemical zonality. They clearly record the sources of heavy-metal loadings. Suggested methods have shown high efficiency during an environment condition appraisal.

\section{Principles of Landscape Geochemical Map Composition and Landscape Geochemical Zonality of Aral Sea Rim}

\section{SHAKHVERDOV V.}

All-Russian Geological Institute (VSEGEI) 4, Sredniy pr., St. Petersburg, 199026 RUSSIA

The Aral Sea rim has widespread artificial contamination of some pollutant heavy metals $(\mathrm{Cu}, \mathrm{Zn}, \mathrm{Pb}, \mathrm{Ni}$ etc.) due to ever-increasing industrial and agricultural production. Landscape-geochemical map were composed to characterize this contamination based on new criteria. The landscape classifications are based on redox and acid-base conditions, which are important factors in determining mobilities in natural waters. The classifications are further subdivided to include: intermediate between acidic and calcic; sulfide acidic; calcic; sodium-calcic; sulfide carbonate neutral; saline; gley saline; sulfide saline; gypsic; and sodic. Each landscape-climatic zone is characterized by a regular series of alternating landscape classes, by the character and position of geochemical barriers and the conditions which favor migration of the elements. The landscape-geochemical map produced in this manner forms the basis for area ecological characterization as well as analysis of the intensities and causes of pollution.

\section{Some Peculiarities of Chemical Element Bioaccumulation in Different Environmental Samples}

SHTANGEEVA, Irina

Institute of Earth Crust, St. Petersburg University, St. Petersburg, Russia

Instrumental neutron activation analysis was used to study the chemical element behavior of plants and soils. Patterns of variations were studied in the elemental composition of samples caused by both physiological reactions of plants and environmental pollution. It was found that there is a regular chemical element redistribution among soil and different parts of plants. For example, even during short periods (several hours), concentrations of some trace elements in any particular plant organ (roots, leaves, etc.) can be increased or decreased by a factor of 10 . In this case, changes in the elemental concentration are caused only by biorhythmic processes.

Roots are excellent physiological barriers which can prevent the transport of toxic chemical elements into generative and reproductive organs. The opposite is also true, roots can stimulate the accumulation of some biologically essential elements.

\section{The Radioactive Mineral Encrustation on the Casings in the Oil-Producing Wells in the Dnieper-Donets Depression, Ukraine}

SHUMLYANSKIY, Vladislav O., BEZUGLA, Maryna V., DUDAR, Tamara V., ZHURAVEL, Nickolay E. Institute of Fundamental Studies, Kyiv, Ukraine (shum@metaldp.kiev.ua)

The Dnieper-Donets depression is the largest oil-gas basin of Ukraine. There are thousands of oil-producing wells in this region. On abandonment, radioactive casings are brought to the surface. Our in vestigations show that the mineral encrustations deposited from the ground waters on the inner surface of casings are the cause of radioactivity.

The casings with radioactivity more than $20,000 \mathrm{BQ}$ $\mathrm{kg}^{-1}$ fall in the high-radioactive category. The mineral 
encrustations of $1.5 \mathrm{~mm}$ thickness are represented by barite $(67 \%)$, galena ( $26 \%)$, feldspar (4\%), strontianite $(2 \%)$ and quartz $(1 \%)$. Small quantities of pyrite and calcite are found as well. Numerous solid microinclusions $(\sim 5-8 \mu \mathrm{m})$ conained $\mathrm{Ni}$ and $\mathrm{Cl}$ predominantly are in galena.

The mineral matter contains $\mathrm{Ra}-1.32 \times 10^{-5} \%$, Th -5.0 $\times 10^{-2} \%$ and $U-2.0 \times 10^{-3} \%$. Total radioactivity $(81,000$ BQ $\left.\mathrm{kg}^{-1}\right)$ to be derived from ${ }^{226} \mathrm{Ra}(17 \%) ;{ }^{214} \mathrm{~Pb}$ and ${ }^{214} \mathrm{Bi}$ $(82.5 \%$ total $)$ and ${ }^{40} \mathrm{~K}(0.5 \%)$.

The low-radioactive $\left(<20,000 \mathrm{BQ} \mathrm{kg}^{-1}\right)$ casings have internal encrustations of $1.5-2 \mathrm{~mm}$ thickness represented by Fe-hydroxides $(97 \%)$, barite $(2.5 \%)$, calcite and halite (total $0.5 \%$ ). There are small segregations of chalcedony, gypsum, galena and sphalerite. The colloform Fe hydroxides (predominantly hydrogoethite) contain Th in all cases in contrast to the circle- and needle-shaped goethite. Ra was identified on spectrogram of halite (microprobe analysis) and maybe represented by $\mathrm{RaCl}_{2}$. Content of $\mathrm{Ra}$ in the mineral encrustations is $(1.39-12.8) \times 10^{-9} \%$ total. Content of Th ranges from $1 \%$ up to $10 \%$. In all, the part of total radioactivity from 63 up to $68 \%$ is derived from ${ }^{238} \mathrm{U}$ group $\left({ }^{226} \mathrm{Ra}\right.$ etc.), and other part - from ${ }^{232} \mathrm{Th}$ group $\left({ }^{232} \mathrm{Th},{ }^{228} \mathrm{Ac},{ }^{212} \mathrm{~Pb}\right.$, and $\left.{ }^{208} \mathrm{Tl}\right)$.

The minerals in casings are deposited from chlorinecalcium-sodium brines characterized by temperatures up to $90^{\circ} \mathrm{C}, \mathrm{pH} 5.8-6.3$ and $\mathrm{Eh}=-110 \mathrm{mV}$. The galena-barite encrustations are formed under low fugacity of oxygen. They contain radioactive isotopes of elements of the ${ }^{238} \mathrm{U}$ group, predominantly: ${ }^{226} \mathrm{Ra}$ in barite; and ${ }^{214} \mathrm{~Pb}$ in galena. 'e-hydroxide encrustations are deposited under high fugacity of oxygen (due to entering of air and ground waters into wells). Radium-226 is in the chloride form associated with halite, and radioactive isotopes ${ }^{232} \mathrm{Th}$-group elements are sorbed by Fe- hydroxides.

\section{The Experience and Results of the Disposal of Liquid Radioactive Waste (LRW) on a Siberian Chemical Industrial Plant}

\author{
SHVARTSEV Stepan L., LUKIN Anatolyi A. and ZUBKOV Andrei \\ A. \\ Tomsk Department of the United Institute of Geology, Geophysics \\ and Mineralogy, SB RAS, prospect Akademicheskij 3, Tomsk, \\ Russia. Tomsk Polytechnical University, Tomsk, Russia. \\ Siberian Chemical Industrial Plant, Seversk, Russia.
}

The Siberian Chemical Industrial Plant (SCIP) has, for more than 30 years, buried its waste in Cretaceous sandy deposits at a depth of $300-350 \mathrm{~m}$. Analysis of this accumulated experience with long-term burial has great importance. Furthermore, now a scientific study of the third stage problems - system conservation is possible. Thus, the main research problem is to accurately define a spreading zone of rdioactive burial, its boundaries of area and geological section by means of a comprehensive examination of the chemistry of underground waters, including major and trace components, heavy metals, organic matter, gases and microflora.
The thickness of cover deposits varies from a few meters to $500 \mathrm{~m}$. The geological section is divided into six porous water-bearing strata divided by six water-confining strata. The strata are of Cretaceous and Paleogene age. Deposits within the research area comprise mainly continental facies (alluvial, lake-alluvial, marsh, etc.). All waterbearing levels are pressured, with the exclusion of the uppermost one (level V). LRW is injected into levels II and III (depth 300-350 m).

The natural hydrochemical systems of the water levels receiving LRW are characterized by fresh bicarbonatecalcium, neutral ( $\mathrm{pH}$ 6.8-7.2), deoxygenated water with Eh values lower than $\pm 100 \mathrm{mV}$. The injected liquid waste composition is nitrate-sodium ( $85-95 \%$ by weight of all dissolved components). The injected LRW solutions have concentrations in the range of $\mathrm{g} \mathrm{L}^{-1}$ (slightly active solutions) up to dozens or hundreds of $\mathrm{g} \mathrm{L}^{-1}$ (median active). The volumes of the more dilute fluid which are injected are an order of magnitude greater than the volume of the more concentrated solutions.

This study of the chemical compositions of underground waters demonstrated that radioactive elements were not found within the levels studied outside the bounds stated by the project. However, a number of new indicators of pollution sources were revealed.

\section{The Distribution of Natural Radioelements in Ground Waters and Post-Cretaceous Sediments from the Southern Mediterranean Margin}

SMITH, B. ${ }^{l}$, POWELL, J.H. ${ }^{1}$, HUTCHINS, M., and TRICK, J.K.', GEDEON, R. ${ }^{2}$, and AMRO, ${ }^{2}{ }^{2}$, CONSTANTINOU, $G{ }^{3}$, AFRODISIS, S. ${ }^{3}$, and CONSTANTINOU, C. ${ }^{3}$

'British Geological Survey, Keyworth, Nottingham, NG12 5GG, United Kingdom

${ }^{2}$ Water Authority of Jordan, Laboratories and Water Quality

Department, Wadi Sir, Amman, Jordan

${ }^{3}$ Department of Geological Survey, Nicosia, Cyprus

Expansion in population, increases in industrial activity and the requirement for better health and hygiene, have resulted in an increasing need for quantifying levels of enhanced natural radioactivity in potable waters and the surficial environment. This is particularly true in the semi-arid areas of Africa and the Middle East, where exposure to environmental radioactivity through use of ground water and atmospheric contamination is increasing with changes in land use and building practices.

This paper describes the results of a three-year collaborative study investigating the distribution of natural series radionuclides ( $U, T h,{ }^{226} \mathrm{Ra}$ and ${ }^{222} \mathrm{Rn}$ ) and associated potentially toxic elements ( $\mathrm{Se}, \mathrm{Mo}$ and $\mathrm{Tl}$ ) in post-Cretaceous sediments and associated ground waters from Cyprus and Jordan. Data are presented from: (a) regional baseline studies that include the determination of natural series radionuclides and other potentially harmful trace elements in ground-water samples, soils and soil gas, (b) an assessment 
of the geochemical origin and mobility of these elements, and (c) the potential hazard resulting from the presence of these elements which in the case of $U$ were found to be in excess of $1,500 \mu \mathrm{g} \mathrm{L}^{-1}$.

Conclusions drawn from these studies emphasize the need for integrated baseline studies in hazard assessments and indicates that the presence and remobilization of naturally occurring radionuclides within the southern Mediterranean basin resulting in significant excess exposure to the general population.

\section{High Resolution Baseline Mapping of Hydrochemical Processes and Their Correlation with Geochemical Anomalies and Anthropogenic Activities: Wales and the Welsh Borders.}

\section{SMITH, B., HUTCHINS, M., RAWLINS, B., and SHAND, P. British Geological Survey, Keyworth, Nottingham, NGI2 5GG, United Kingdom}

The completion of the high resolution (ca. 1 sample per 2 $\mathrm{km}^{-2}$ ) geochemical survey of Wales and the Welsh Borders by the British Geological Survey has created a unique data set. This compilation contains over 12,000 site specific hydrochemical and stream sediment analyses for a typical suit of over 20 major and trace components. The collection of such a wide range of data over an area with large variations in geomorphology and geology has enabled the delineation of hydrochemical processes on a regional basis. Methods are presented describing transformations performed from basic concentration-based data sets containing $\mathrm{pH}$, conductivity and concentrations of 21 major and trace elements into hydrochemically relevant trilinear and solubility diagrams. These data are used in predicting aqueous speciation and ionic domination throughout the sampled data sets. These data are then displayed and interpreted using a series of thematic RGB composites in conjunction with data for bedrock geology, landuse and industrial activity.

The utility of coupling speciation diagrams, based upon pure ideal systems, with Geographical Information Systems for describing processes controlling hydrogeochemical evolution at a regional scale is described. Using PHREEQEC, the validity of solubility diagrams for describing large regional hydrochemical data sets is tested as well as the use of geographically-linked representations of aqueous saturation and chemical speciation (generated from the modeling of over 12,000 individual samples).
Geochemical Factors Controlling Infantile Exposure to Cerium and its Implications to the Aetiology of Endomyocardial Fibrosis in Uganda

SMITH, B.', COOK, J.', STYLES, M.', and CHENNERY, S.R.N.', TIBERINDWA, J.V. ${ }^{2}$, HAMPTON, C. ${ }^{2}$, FREERS, J. ${ }^{3}$, RUTAKINGGIRWA, M. ${ }^{3}$, and SSERUNJOGI, L. ${ }^{3}$, TOMKINS, A.4, BROWN, C.J. ${ }^{\mathrm{s}}$

'British Geological Survey, Keyworth, Nottingham, NGI2 5GG, United Kingdom

${ }^{2}$ Makerere University Geology Department, Kampala, Uganda

${ }^{3}$ Mulago Hospital, Kampala, Uganda

'Institute of Child Health, Gt. Ormond Street, London, WCIN IEH, United Kingdom

${ }^{5}$ Eastman Dental Institute, 256 Grays Inn Road, London, WCIX $8 L D$, United Kingdom

The presence of elevated levels of Ce coupled with deficient levels of $\mathrm{Mg}$ in southern India have been assigned as potential environmental cofactors in the aetiology of Endomyocardial Fibrosis (EMF). However, environmental exposure to $\mathrm{Ce}$ in tropical environments where EMF is prevalent is poorly understood due to wide variations in geochemical environments and local dietary habits. This paper describes collaborative studies performed in Uganda to define environmental exposure pathways within a region in which EMF is endemic, were EMF represents the most common form of infantile heart condition.

Data are presented from a survey of major foodstuffs, soils and waters which indicate that the most probable pathway for Ce exposure is from dust and inadvertent carriage of soil. In addition to substantiating observations made in southwestern India, detailed studies of Ugandan soils, dusts and waters indicate that $\mathrm{Ce}$ within the Ugandan environment is controlled by the presence of $<20 \mu \mathrm{m}$, secondary rare earth phosphates rather than primary monazites as has been assumed by workers in India.

In addition to assessing potential exposure pathways the hypothesis that environmental exposure to $\mathrm{Ce}$ is enhanced among Ugandan populations with a high EMF prevalence is tested by comparison of Ce levels in deciduous teeth using inductively coupled plasma mass spectrometry, and through high resolution element mapping using electron microprobe techniques. 


\section{Geochemical Characterization of a Fluvial Tailings Deposit Along the Arkansas River, Colorado, USA}

\author{
SMITH, Kathleen S.', JERZ, Jeanette $K .^{2}$, RANVILLE, James $F_{.}{ }^{2}$, \\ WALTON-DAY, Katherine ${ }^{3}$, SUTLEY, Stephen J. ${ }^{\prime}$, MEIER, Allen \\ L.' , and BRIGGS, Paul H.' \\ ${ }^{\prime}$ U.S. Geological Survey, DFC, Box 25046, MS 973, Denver, CO \\ 80225 \\ ${ }^{2}$ Dept. Chemistry and Geochemistry, Colorado School of Mines, \\ Golden, CO 80401 \\ ${ }^{3}$ U.S. Geological Survey, DFC, Box 25046, MS 415, Denver, CO \\ 80225
}

Historic mining activities near Leadville, Colorado, have resulted in deposition of fluvial tailings along the Arkansas River. These tailings are enriched in several metals, including $\mathrm{Cu}, \mathrm{Pb}$, and $\mathrm{Zn}$, and are a potential non-point source of metal and acid contamination to the river. We are characterizing the geochemical properties of a fluvial tailings deposit located about $13 \mathrm{~km}$ downstream of Leadville. The deposit is approximately $0.1 \mathrm{~km}^{2}$ in size and is predominantly barren of vegetation, although there are remnants of dead willows. We collected 20 one-inch diameter continuous cores from the deposit to assess depth of tailings and degree of metal mobilization. The cores varied in length from 10 to $58 \mathrm{~cm}$. We separated the cored material into visually distinct sections that were analyzed for bulk total chemistry and mineralogy. We also collected

fflorescent salts that occasionally form on the surface of the tailings material. Cored material and salts were subjected to leaching with deionized water. Preliminary results indicate that the pyrite-rich portion of the tailings contains about $14 \%$ pyrite, whereas other portions of the deposit contain only trace amounts of pyrite $(<2 \%)$. Jarosite also has been identified in the top portion of the tailings deposit. Water leachates of the cored material exhibit low $\mathrm{pH}$ values (about 2.5-3.5) and contain elevated concentrations of several metals. A 20:1 (wt. water to wt. solid) deionized water leach of the pyrite-rich tailings material (filtered through $0.45 \mu \mathrm{m}$ ) contained about $300 \mathrm{mg} \mathrm{L}^{-1}$ of Fe, $14 \mathrm{mg} \mathrm{L}^{-1}$ of $\mathrm{Al}, 8 \mathrm{mg} \mathrm{L}^{-1}$ of $\mathrm{Zn}, 3 \mathrm{mg} \mathrm{L}^{-1}$ of $\mathrm{Cu}, 1.6 \mathrm{mg} \mathrm{L}^{-1}$ of $\mathrm{Pb}$, and $0.2 \mathrm{mg} \mathrm{L}^{-1}$ of As. A similar leach of pyrite-poor tailings material contained about $0.5-3 \mathrm{mg} \mathrm{L}^{-1}$ of Fe, $1-6 \mathrm{mg} \mathrm{L}^{-1}$ of $\mathrm{Al}, 2-8 \mathrm{mg} \mathrm{L}^{-1}$ of $\mathrm{Zn}, 0.05-0.2 \mathrm{mg} \mathrm{L}^{-1}$ of $\mathrm{Cu}$, and up to $0.4 \mathrm{mg} \mathrm{L}^{-1}$ of $\mathrm{Pb}$. Leachates from efflorescent salts contain 1,000's $\mathrm{mg} \mathrm{L}^{-1}$ of $\mathrm{Fe}, 100$ 's $\mathrm{mg} \mathrm{L}^{-1}$ of $\mathrm{Al}$, 10's mg L $\mathrm{m}^{-1}$ of $\mathrm{Zn}, 1$ 's $\mathrm{mg} \mathrm{L}^{-1}$ of $\mathrm{Cu}$, $\mathrm{Pb}, \mathrm{As}$, and $\mathrm{Mn}$, and 0.1 's $\mathrm{mg} \mathrm{L}^{-1}$ of $\mathrm{Cd}$ and $\mathrm{V}$. These salts appear to make a significant contribution to the waterleachable fraction of metals and acidity in the tailings material.

\section{A Chemical and Mineralogical Reconstruction of Emissions from $\mathrm{Zn}$ Smelters in the Kempen Region (Belgium), Based on Peat Cores}

\author{
SONKE, Jeroen', HOOGEWERFF, Jurian², VAN DER LAAN, \\ Sieger', VANGRONSVELD, Jacco ${ }^{3}$ \\ 'Deptartment of Geochemistry, Institute for Earth Sciences, \\ Utrecht University, Budapestlaan 4, 3584 CD Utrecht, The \\ Netherlands \\ ${ }^{2}$ Bundesforschung- und Prüfzentrum ARSENAL, Geotechnisches \\ Institut, Abteilung für Analytische Geochemie, Faradaygasse 3. A- \\ 1031 Vienna, Austria \\ ${ }^{3}$ Dept. Biology, University Centre Limburg, Universitaire Campus \\ Gebouw D, B-3590 Diepenbeek, Belgium
}

To reconstruct the life-long airborne dust exposure of people in the vicinity of $\mathrm{Zn}$-smelters in the Belgian Kempen, cores were taken from peat bogs in the polluted area. Peat bogs are well-known to preserve atmospheric heavy metal inputs through adsorption and sulfide precipitation processes. In a pilot study a $50 \mathrm{~cm}$ deep peat core was taken from a peat bog pool, situated $500 \mathrm{~m}$ from a former $\mathrm{Zn}$-smelter (closed in 1974). The core has been sub-sampled at $1 \mathrm{~cm}$ intervals and subsequently dissolved with $\mathrm{HF} / \mathrm{HClO}_{4} / \mathrm{HNO}_{3}$ mixture for ICP-AES major and trace elements. The results show extreme anthropogenic pollution for metals $\mathrm{Zn}, \mathrm{Pb}, \mathrm{Cu}, \mathrm{Cd}$, $\mathrm{Co}, \mathrm{Sn}, \mathrm{V}$ and $\mathrm{Cr}$. Concentration profiles indicate an increase from geogenic values at $50 \mathrm{~cm}$ depth to distinct peaks at $24,17,13$ and $7 \mathrm{~cm}$. The $7 \mathrm{~cm}$ peak contains up to $4 \mathrm{wt} . \% \mathrm{Zn}$ and $1 \mathrm{wt} . \% \mathrm{~Pb}$. Above the $7 \mathrm{~cm}$ peak a decrease to lower, but still polluted, values is probably linked secondary remobilization after the smelter shut-down. Normalizing metal/Al ratios to unpolluted ratios (Shotyk, 1996) gives enrichment factors up to 300 for $\mathrm{Zn}$ and $\mathrm{Pb}$. First results from ICP-MS measured ${ }^{206} \mathrm{~Pb} /{ }^{207} \mathrm{~Pb}$ ratios show anthropogenic values (1.130) at the peaks and more geogenic values at depth. We performed SEM and microprobe analysis on thin sections from the same core to investigate heavy metal mineralogy. The primary aerosol input from chimneys and wind-blown ore deposits are clearly subject to post-depositional redistribution in the anoxic peat environment. Zinc sulfide dust particles are stable throughout the core, but extensive precipitation of $\mathrm{FeS}_{2}$ (pyrite), $\mathrm{ZnS}$ (sphalerite) and minor $\mathrm{PbS}$ and $\mathrm{CuFeS}$ suggest an additional mineral phase in the dust. These are probably $\mathrm{Zn} / \mathrm{Pb}$ oxides and sulfates, which are reduced and redistributed upon entering the anoxic zone. $\mathrm{PbSO}_{4}$ particles are indeed encountered in the upper $7 \mathrm{~cm}$ of the core. Zinc sulfide precipitates are located preferentially within organic cell-structures and show extensive coprecipitation of $\mathrm{Fe}, \mathrm{Pb}$, $\mathrm{Cd}, \mathrm{Cu}, \mathrm{Co}$ and As. Mass balance calculations with mineral compositions and bulk analysis data reveal different redistribution pathways for $\mathrm{Zn}$ and $\mathrm{Pb}$. Whereas $\mathrm{Zn}$ is mainly precipitated, $>75 \%$ of anthropogenic $\mathrm{Pb}$ is involved in a different process, probably adsorption onto organic matter or clay minerals.

Shotyk W.,1996, Environmental Reviews 4: 149-183 


\section{Small Scale Spatial Relationships Between Geology, Stream Water Chemistry and Stream Sediment Chemistry in Small Upland Catchments}

STAINES, Russell', BILLETT, Michael F.', and SIMPSON Peter ${ }^{2}$ 'University of Aberdeen, Department of Plant and Soil Science, Cruickshank Building, Aberdeen, AB24

${ }^{2}$ British Geological Survey, Keyworth, Nottingham, NGI2 5GG.

Relationships between bedrock lithology, stream water chemistry and stream sediment chemistry have been in vestigated in two catchments in North East Scotland. A suite of bedrock samples from the catchments were chemically and mineralogically analyzed. Chemical analyses were also carried out on water samples collected monthly from $50 \mathrm{~m}$ intervals along the length of each stream and one set of stream sediment samples, collected from the same sites as the stream waters.

Each stream exhibits strong spatial changes in solute chemistry from the top to the bottom of the catchment. These changes appear to be strongly related to weathering of the underlying parent materials. As discharge increases, the concentrations of solutes change and the chemical trends become less distinct. However, the general patterns persist under all flow regimes. Apart from showing clear relationships between chemically distinct lithological units and stream water, the underlying parent materials also produce pronounced small scale changes in stream sediment chemistry.

The study of stream water chemistry at such a small scale shows that it has great potential for use in geochemical/ geological mapping and could be of particular use in poorly exposed areas. It may also potentially be a better indicator of changes in underlying geology than stream sediment chemistry.

\section{Mineral Crusts or Microbial Mats?}

\section{Alteration of Surficial Mine Tailings in the Leadville District, Colorado}

\author{
STANTON, Mark R.', VAUGHN, Robert B. ', SWAYZE, Gregg A. ', \\ and ROBBINS, Eleanora I. ${ }^{2}$ \\ 'U.S. Geological Survey, MS 973, DFC, Denver, CO 80225 \\ ${ }^{2}$ U.S. Geological Survey, MS 956, National Center, Reston, VA \\ 20192
}

In the Leadville Mining District in central Colorado, weathering of pyrite and other sulfide minerals exposed in surficial mine tailings at high elevations $\left(\_3000 \mathrm{~m}\right.$ ) has produced brightly-colored red and yellow mineral crusts on the tailings and downslope rocks, soils, and sediments. These crusts are composed of variable mixtures of sulfate and iron oxide minerals such as jarosite, copiapite, goethite, and hematite. Despite intermittent rainfall and intense UV radiation during the summer months, microbes appear to be active in these mineral crust environments. Most samples from surficial crusts contain relict and potentially living bacterial cells and filaments, and fungal hyphae; some samples indicate the presence of algal filaments.

Samples of the crusts have been inoculated into vials of sterile water, and minimal salts, freshwater, and other isolation media to culture and characterize microbes in the mineral crusts and tailings. Yellow sulfate-bearing crusts appear to be supplying some nutrient(s) since yellow colonies similar to ones observed in the field are growing on the vial walls in sterile water. One red crust inoculum has sprouted green algal filaments. Microbes also appear active at an old (1930's) mill/smelter site where a 1-m thick $90 \%$ (wt. \%) hematite crust with $10 \%$ admixed sulfate minerals has been produced from tailings rich in fine-grained (crushed) pyrite. At this site, the odor of sulfur gasses suggests that alteration and/or decomposition of $\mathrm{FeS}_{2}$ and other metal sulfides is occurring within the tailings and nearby soils possibly via microbial action. Initial scanning electron microprobe analyses indicate localization of high abundances of $\mathrm{P}, \mathrm{Fe}$, and $\mathrm{S}$ in the surficial crusts and isolated nodules may be related to a microbial origin.

These preliminary findings suggest an active role for microorganisms in the formation of $\mathrm{Fe}$ - and $\mathrm{SO}_{4}{ }^{2}$-rich mineral crusts in the tailings and in subsequent production of acid drainage from fine-grained sulfides. Microbial pigments and defense mechanisms that affect the absorption or reflection of light may be helping to produce the characteristic colors or the formation of the mineral varieties.

\section{Comparison of Ground-Water Chemistry from the Carbonate Platform Region of the Ozark Mountains, USA}

STEELE, Kenneth F. and AUSTIN, Andrew Y.

Arkansas Water Resources Center and Department of Geology, University of Arkansas, Fayetteville, AR 72701, USA

Ground-water chemistry for three, confined and unconfined, aquifers from the Ozark Mountains carbonate plateau region in northern Arkansas was determined from domestic well samples collected during "wet" and "dry" seasons. The diversity of the ground-water chemistry is related directly to the variety of lithologies and depth of the flow system. Three aquifer systems and associated water types are present: (1) shallow, $(\mathrm{Na}, \mathrm{Mg})-\left(\mathrm{HCO}_{3}, \mathrm{SO}_{4}\right)$-type waters in a clastic aquifer, (2) intermediate depth, $\mathrm{Ca}-\mathrm{HCO}_{3}$-type water in the Springfield Plateau, and (3) deeper, CaMg-Ca$\mathrm{HCO}_{3}$ in the Ozark aquifer. The intermediate Springfield Plateau aquifer was determined to have two distinct types of water chemistry dependent on the presence or absence of overlying clastic rocks There was no significant seasonal variation in water chemistry.

The deeper, dolomitic Ozark aquifer contains significantly higher $\mathrm{Mg}$ than both of the shallow water types; whereas, the intermediate depth, limy Springfield Plateau aquifer has higher concentrations of $\mathrm{Ca}$ than the deep Ozark 
aquifer and the shallow clastic aquifer. The deep aquifer has significantly less $\mathrm{Na}, \mathrm{Cl}$ and $\mathrm{SO}_{4}$ than the others. The Springfield Plateau aquifer has statistically significantly higher $\mathrm{NO}_{3}+\mathrm{NO}_{2}$ as $\mathrm{N}$ concentrations $\left(1.19\right.$ and $1.02 \mathrm{mg} \mathrm{L}^{-1}$ or wet and dry seasons, respectively) than the Ozark aquifer ( 0.04 and $0.06 \mathrm{mg} \mathrm{L}^{-1}$ for wet and dry seasons, respectively). However, the former has higher concentrations than the shallow clastic aquifer $\left(0.21\right.$ and $0.42 \mathrm{mg} \mathrm{L}^{-1}$ for wet and dry seasons, respectively) but only during the wet season. These nitrate relationships are a result of a lack of little land use in the steep, clastic aquifer areas and the relatively heavy land use directly overlying the carbonate aquifer areas. These latter areas are used for confined animal production and the waste from these activities and domestic septic systems combine to contaminate the more shallow Springfield Plateau aquifer; whereas, the Ozark aquifer is protected by its greater depth and an overlying confining unit.

\section{Iron Deposition and Magnetic Susceptibility of Forest Soils in Katowice Province}

\author{
STRZYSZCZ, Zygmunt, and MAGIERA, Tadeusz \\ Institute of Environmental Engineering, Polish Academy of \\ Sciences, ul. Sklodowskiej-Curie 34, 41-819 Zabrze, Poland
}

Katowice Province is situated in southern Poland, covering ca. $6,650 \mathrm{~km}^{2}\left(2.1 \%\right.$ of Polish territory $\left.-312683 \mathrm{~km}^{2}\right)$. Almost all coal mines (56), steel plants (11) and non-ferrous netal plants (6), coking plants (6), cement plants (2) and most importantly, power and thermal power plants which burn hard coal (14) are concentrated in this small area. Monitoring of emitted industrial dusts started in 1970. The highest observed value was $1750 \mathrm{gm} \mathrm{m}^{-2} \mathrm{a}^{-1}$, and the lowest $90 \mathrm{gm} \mathrm{m}^{-2} \mathrm{a}^{-1}$. In 1981 the first map of the iron fall was made, which showed that on $64 \%$ of Katowice Province territory the dust fall varied from 10 to $35 \mathrm{gm} \mathrm{m}^{-2} \mathrm{a}^{-1}$ (maximum $242 \mathrm{gm} \mathrm{m}^{-2} \mathrm{a}^{-1}$, minimum $3.8 \mathrm{gm} \mathrm{m}^{-2} \mathrm{a}^{-1}$ ), on $32 \%$ reached values $<10 \mathrm{gm} \mathrm{m}^{-2} \mathrm{a}^{-1}$, on $3 \%$ varied from 35 to 60 $\mathrm{gm} \mathrm{m}^{-2} \mathrm{a}^{-1}$ and on $1 \%$ reached $>60 \mathrm{gm} \mathrm{m}^{-2} \mathrm{a}^{-1}$. Mineralogical research of the industrial dusts revealed the presence of hematite and magnetite. The investigation of magnetic susceptibility of forest soils was started in 1987 and in the study area varied from 294 to $1493 \times 10^{-4} \mathrm{~m}^{3} \mathrm{~kg}^{-1}$. This value cannot be met in the other regions of Poland, Europe or in other parts of the world, except regions situated close to the iron plants. The correlation coefficients ( $r$ ) between dust fall, iron fall, and magnetic susceptibility of forest soils were: $r=0.677$ and $r=0.440$, respectively. Higher values of correlation coefficients between magnetic susceptibility of forest soils and concentrations of some heavy metals was also confirmed: $\mathrm{Zn}(\mathrm{r}=0.618$ to 0.986$), \mathrm{Pb}(\mathrm{r}=0.724$ to $0.979)$ and $\mathrm{Cd}(\mathrm{r}=0.175$ to 0.581$)$.

\section{Temporal Variation in the Concentrations and Speciation of Metals in Peru Creek, Summit County, Colorado}

\author{
SULLIVAN, Annett B. ', DREVER, James I.' and McKNIGHT, \\ Diane $M^{2}$ \\ 'Department of Geology and Geophysics, University of Wyoming, \\ Laramie, WY 82071, USA \\ ${ }^{2}$ Department of Civil, Environmental and Architectural \\ Engineering, University of Colorado, Boulder, CO 80309, USA
}

Peru Creek, a headwater stream of the Colorado River, is affected by metal-bearing, acid waters draining from the abandoned silver mines found along its reach. Drainage from the Pennsylvania Mine contributes most of the heavy metals. Zinc concentrations, for instance, rise to 20 times upstream levels after input of the Pennsylvania Mine drainage.

At the peak of snowmelt, there are diurnal cycles in $\mathrm{Fe}$, $\mathrm{Mn}, \mathrm{Zn}, \mathrm{Si}, \mathrm{Al}, \mathrm{Ca}, \mathrm{Mg}, \mathrm{SO}_{4}$ and $\mathrm{NO}_{3}$ concentrations in Peru Creek. Most of these cycles correlate to the diurnal variations in streamflow that occur during the snowmelt season. When snowmelt ends and the diurnal flow cycles are minimal, only iron and nitrate and DOC still show diurnal concentration variations. Iron concentrations follow changes in UV radiation ( $300-400 \mathrm{~nm}$ ) which suggests that the diurnal variation in iron chemistry is controlled by photochemistry, a process demonstrated to be important in the nearby Snake River. There are seasonal cycles in metal chemistry as well; metal concentrations in the creek more than triple from the peak of snowmelt through to baseflow conditions.

In addition to the observed diurnal and seasonal cycles in metal concentrations, preliminary data suggest that there are also temporal variations in metal speciation. Fieldwork in summer 1997 will examine metal speciation in Peru Creek using tangential flow filtration to size separate the metals in the creek water into different size fractions. The speciation of the metals in those size fractions will be determined.

\section{Unraveling the Degree and the History of Environmental Pollution Based on the Evaluation of Vertical Geochemical Profiles in Overbank Sediments}

SWENNEN, R., VAN DER SLUYS, J., and VERKEYN, $M$. Belgian Geological Survey, Jennerstraat 13, Brussels B-1000, Belgium

Parallel to the geochemical mapping project based on overbank sediments in Belgium and Luxembourg (Swennen et al., 1997) a detailed sampling of 30 different overbank profile sites has been carried out. The $<125 \mu \mathrm{m}$ fraction was analyzed by XRF for determination of the major element and ICP-AES for $>20$ trace element content.

In general in most profiles the geochemistry of the deepest samples display a relation to the geological substra- 
tum and thus reflect natural background concentrations. The contrast between the northern part of Belgium where unconsolidated sandy/silty lithologies of Cenozoic age dominate and the southern part of Belgium and Luxembourg where shales, sandstones and carbonates of Paleozoic and Mesozoic age are more characteristic is clearly reflected in the profiles. In several profiles an increase in heavy metals $(\mathrm{Zn}, \mathrm{Pb}, \mathrm{Cu}, \mathrm{Cd})$ towards the top is apparent. While in most profiles this increase is rather gentle and concentrations are still moderate, in areas with (former) mining and smelting industries this increase is nearly always drastic and concentrations in percentage level have been measured. Notice, however, that in about $10 \%$ of the profiles high element concentrations over the entire sampling interval which is interpreted in terms of pollution since in these profiles, anthropogenic particles such as slag, charcoal, plastic and brick have been recognized.

A kind of overbank typology has been worked out, grouping the different geochemical patterns, namely:

Type A: profiles reflecting natural distributions.

Type B: distributions with clear evidences of anthropogenic influences

Type C: superimposed on type A and B are element distributions which are explained by element mobilization due to pedogenic processes (eluviation/illuviation, gleying). Based on the results of this study it can be stated that for a thorough evaluation of geochemical characteristics of overbank sediments for geochemical mapping purposes it is worthwhile to study particular profiles in detail. Vertical geochemical overbank sediment profiles clearly reflect element variations through time, reflecting the historical evolution in the drainage basin.

\section{Ground-Water Flow System Estimated by Water Quality}

TAGUTSCHI, Yuhsaku

Geological Survey of Japan, Tsukuba, Ibaraki, 305 Japan

It is well known that ground-water quality gradually changes by ion exchange and other reactions with soil particles with keeping long residence time going through the process of ground-water flow. Conversely, there is some possibility that ground-water flow in a basin can be traced using ground-water quality as the tracer. Especially, ground-water quality will be the most important tool for estimating the ground-water flow system in the place where an areal distribution of hydraulic potential could not be clarified. The author proposes how to estimate the ground-water flow system in the basin, where there is little information on hydrogeology, from the results of the water quality analysis for ground water. For this purpose, the author selected the Hayadegawa basin, Japan, where there are a lot of information on hydrogeology, as the area for this study. The result of ground-water flow system estimated by this method was harmonized with that known by previous hydrogeological studies. It means this method proposed by the author here has some possibility to be applicable to field surveys.

\section{Radiometric Risk Mapping Using Existing Geoscience Data Sets}

TALBOT, D.K., BALL, T.K., and JONES, D.G.

Geochemistry Group, British Geological Survey, Keyworth, Notts NG12 5GG, UK

The British Geological Survey (BGS) has collected a wide range of environmental radiochemistry data over a period of about 50 years. In the UK data are also held by a number of official bodies. These data have never been collated to present a coherent picture of the natural radiation environment. The Natural Environmental Radioactivity Survey (NERS) project commenced in 1995. It aims to produce a comprehensive digital database, GIS and maps at 1:250,000 scale showing the distribution of natural gamma radioactivity and radon potential. Radon isotopes account for over $50 \%$ of the average radiation dose to UK citizens. Existing information on radon levels includes the indoor house radon measurements undertaken by the National Radiological Protection Board. The house radon values were found to be log-normally distributed when grouped on bedrock geology. This observation allows the proportion of housing with radon levels above the UK action level to be estimated from a small number of measurements. In areas with little or no house radon data, risk assessments can be made based on soil gas radon surveys or laboratory analyses and consideration of the geochemistry and permeability of the underlying rocks. Natural gamma radiation from daughter nuclides of the $\mathrm{U}$ and $\mathrm{Th}$ decay series and from $\mathrm{K}$ accounts for about $14 \%$ of the average radiation dose of a UK citizen. Gamma exposure rates have been calculated from $U$, Th and $K$ analyses held within the database, supplemented by the use of borehole gamma logs to estimate exposure rates for geological formations where the geochemical data are inadequate. In areas where these data sets proved inconclusive, surface gamma rate meter and spectrometric measurements have been made. Combining all these data has allowed a comprehensive map of the bedrock surface gamma exposure rate to be produced for the first time.

\section{A Comparison Of Field And Laboratory Analytical Methods Of Radon-Potential Mapping In Areas With And Without Glacial Drift Coverage}

TALBOT, D.K., APPLETON, J.D., BALL, T.K., and STRUTT, M.H. Geochemistry Group, British Geological Survey, Keyworth, Notts, NG12 5GG, UK

Soil gas radon measurements provide a valuable tool in assessing probable indoor radon levels on a regional basis. However, during the winter months precipitation exceeds evapotranspiration, which can cause significant changes in soil moisture in a short period of time, thus leading to large changes in soil-gas radon. Although this poses little problem when carrying out systematic radon potential mapping 
programs, there are difficulties in responding to ad-hoc requests for site specific radon investigations.

To develop a method of radon potential mapping and site investigation which can be used at any time of the year, he relationship between soil gas radon (measured in the field) and the radon released from a representative sample of soil in the laboratory has been investigated. Multiple soil and soil-gas samples were collected from sites underlain by bedrock with widely varying radon potentials. For each geological unit, sites both free and covered by glacial drift deposits were sampled. Soil and soil-gas samples were taken at the same depth of $60-100 \mathrm{~cm}$ and field gamma spectrometric measurements made.

Although a good correlation between the two methods of estimating radon potential was observed in Derbyshire, where the range of radon potential is very great, no significant correlation was observed in Northamptonshire, which is characterized by a smaller range of radon potential. In general, measurement of soil gas radon in the field provides a more reliable indication of radon potential than measurement of radon emanation in the laboratory, especially when soil permeability is also taken into consideration. If soil gas radon concentrations cannot be determined because the soil profile is waterlogged, gamma spectrometry combined with soil permeability may provide an alternative.

\section{Delineating Risk Areas of Contaminated Ground Water Using Geochemical Databases}

TARVAINEN, Timo and PAUKOLA, Tarja, Geological Survey of Finland, FIN-02150 Espoo, Finland

Drinking water is the most common pathway through which people are exposed to harmful geogenic elements. At present, about $20 \%$ of the population in Finland rely on their own water supply, particularly in sparsely populated rural areas. The natural concentrations of As and $F$, for example, exceed the recommended guidelines for water quality in several parts of the country. The nationwide geochemical maps of till, organic stream sediments and stream waters have been used to delineate high-risk areas with respect to contamination of drinking water. The results are compared with concentrations of the same elements in ground water. All data sets are from the geochemical databases of the Geological Survey of Finland.

Anomalous concentrations of several elements (e.g. Cr, $\mathrm{Cu}, \mathrm{Mn}, \mathrm{Ni}$ and $\mathrm{Zn}$ ) in the fine fraction of till have been measured from five selected provinces in Finland. In these areas, the concentrations of $\mathrm{Mn}$ and $\mathrm{Ni}$ in drilled bedrock wells as well as the concentrations of $\mathrm{Ni}$ and $\mathrm{Zn}$ in dug wells exceeded the water quality guidelines in several groundwater samples. Concentrations of $\mathrm{Cr}$ and $\mathrm{Cu}$ in ground water /ere slightly elevated in the same areas, but the recommended limits for these elements are seldom exceeded in Finland. Areas with high concentrations of As in drilled bedrock wells could be delineated using either till geochem- istry or organic stream sediments. Anomalies of F are similar in stream water and ground-water maps.

Geogenic contamination of ground water commonly occurs in areas that can be delineated using geochemical maps based on till, stream water or stream sediment. However, not all of the contaminated wells were identified from geochemical maps at reconnaissance scale.

\section{The Use of Sedimentation Field Flow Fractionation - Inductively Coupled Plasma Mass Spectrometry for the Chemical Characterization of Suspended Particulate Matter in Environmental Hydrologic Systems}

TAYLOR, Howard E.' and SHILLER, Alan M. ${ }^{2}$

'U.S. Geological Survey, 3215 Marine Street, Boulder, CO 80303 1066, USA

${ }^{2}$ University of Southern Mississippi, USA

Colloidal suspended particulate matter (particle diameters $<1 \mu \mathrm{m}$ ) provides a high surface area component in hydrologic systems for the adsorption of trace contaminants. Because of the unique nature of these particulates (i.e. high mobility in natural systems), they provide a significant mechanism for the hydrologic transport of contaminants. The chemical characterization of these particulates, as a function of particle size, is critical to understanding processes that have a significant impact on trace element geochemistry and the fate of trace contaminants in hydrologic systems.

Sedimentation field flow fractionation - inductively coupled plasma mass spectrometry (SdFFF-ICP-MS) provides a technique for both the separation of submicrometer diameter particulates and the direct, on-line elemental characterization of these separated particles in hydrologic samples, including both the basic composition of the particulate and surface-adsorbed trace elements. This presentation describes the state-of-the-art development of the technique, including the specific details of the configuration of the system. Capabilities, advantages and limitations of this technology will be discussed using examples of specific hydrologic applications.

\section{Contaminant Dynamics in Port Jackson Estuary, Sydney, Australia}

TAYLOR, S.E. and BIRCH, G.F.

Department of Geology and Geophysics, University of Sydney, NSW 2006, Australia.

Sediment samples from 1200 locations throughout the entire Port Jackson catchment were size-normalized $(<63 \mu \mathrm{m}$ fraction) and analyzed for a suite of heavy metals. A subset of estuarine samples were also analyzed for nutrients and 
organochlorine compounds. Shallow ( $<8 \mathrm{~m}$ water depth) off-channel embayments which form an large proportion of Port Jackson, are mantled in easily resuspended contaminated surficial sediment termed the "hydrous layer". A marked seaward decrease in sediment contaminant concentrations away from storm water canals is related to proximity to source and organic carbon content.

Six sediment traps deployed weekly in Iron Cove over 42 weeks provide time-integrated samples of settling particulate matter (SPM). Comparable heavy metal and organic carbon concentrations of the SPM and ambient hydrous material at each sediment trap location implies that the majority of the trapped material is derived from sediment by resuspension. SPM flux rates during summer are four times higher than in winter, probably due to decreased resuspension threshold velocities or increased biological activity. Mechanisms of sediment resuspension and dissolved phase contaminant concentrations have also been investigated. Anthropogenic activities, such as trawling, have been shown to increase turbidity and SPM flux rates. Physical, biological and anthropogenic processes continuously resuspend surficial estuarine sediment and associated toxicants into the water column. Resuspension and secondary sourcing of highly contaminated sediments is probably occurring in many of the shallow water environments of Port Jackson and other anthropogenically impacted estuarine systems, thereby providing a pathway for contaminants to enter the foodchain.

\section{Adsorption of Metal Cations on Manganese Oxide-Coated Filter Sand-A Novel Method for Water Treatment}

\section{THOMSON, Bruce and NICHOLSON, Keith}

Environmental Geochemistry Research Group, School of Applied Sciences, The Robert Gordon University, Aberdeen, AB25 IHG, Scotland

Manganese oxide derived from natural waters and deposited on the filter sand of a water treatment plant has the capacity to adsorb metal cations from solution. The extent of adsorption is influenced by the $\mathrm{pH}$ as well as the nature of the metal cation. Over a pH range of 3-7 almost $90 \%$ is adsorbed and is least affected by $\mathrm{pH}$. Although $\mathrm{Cu}$ is also readily adsorbed, the extent of adsorption at $\mathrm{pH} 3$ is $20 \%$ which increases to $90 \%$ at $\mathrm{pH} 6$. In comparison with $\mathrm{Pb}$ the adsorption of $\mathrm{Cu}$ is more $\mathrm{pH}$ dependent. The adsorption of $\mathrm{Zn}$ and $\mathrm{Cd}$ is similar over the same $\mathrm{pH}$ range with some 60 $\%$ of the added metal cations being adsorbed at $\mathrm{pH} 7$ and is markedly $\mathrm{pH}$ dependent. No adsorption of Ni takes place at $\mathrm{pH} 3$ and 4 and only $44 \%$ of the added $\mathrm{Ni}$ is adsorbed at $\mathrm{pH}$ 7. Overall the adsorption of $\mathrm{Pb}, \mathrm{Cu}, \mathrm{Cd}, \mathrm{Zn}$, and $\mathrm{Ni}$ has been found to be (in decreasing order of adsorption) $\mathrm{Pb}>\mathrm{Cu}>\mathrm{Cd}>\mathrm{Zn}>\mathrm{Ni}$ in the $\mathrm{pH}$ range $3-7$.

Studies of the reaction rates with the exception of Cadmium indicated that the reaction is first order. The reaction rates vary depending upon the cation adsorbed, and the rate constants vary in the order $\mathrm{Pb}>\mathrm{Cu}>\mathrm{Zn}>\mathrm{Ni}$. The Arrhenius activation energies and rate constants at 295, 313 and $333{ }^{\circ} \mathrm{K}$ are shown in the table. The activation energies indicate that the reaction takes place readily and is chemisorptive in nature. Attempts to model the adsorption isotherm indicate that the data obeys the Langmuir equation.

\begin{tabular}{llll}
\hline Cation & Temp. ('K) & $\mathrm{k} \mathrm{min}^{-1}$ & E kj mol $^{-1}$ \\
$\mathrm{~Pb}$ & 295 & 0.134 & \\
& 313 & 0.156 & 23.8 \\
& 333 & 0.346 & \\
$\mathrm{Cu}$ & 295 & 0.081 & \\
& 313 & 0.109 & 16.2 \\
& 333 & 0.158 & \\
$\mathrm{Ni}$ & 295 & 0.058 & \\
& 313 & 0.103 & 16.9 \\
& 333 & 0.118 & \\
$\mathrm{Zn}$ & 295 & 0.058 & \\
& 313 & 0.093 & \\
& 333 & 0.168 &
\end{tabular}

\section{Perched Water Zones in Arid Environments: Geochemical Constraints on Hydrological Modeling for High-Level Radioactive Waste Disposal}

TURNER, David R.', BAGTZOGLOU, Amvrossios C. ${ }^{2}$ TOLLEY, Timothy L. ', and STOTHOFF, Stuart, A.'

${ }^{\prime}$ Center for Nuclear Waste Regulatory Analyses, 6220 Culebra Rd, San Antonio, TX 78238, USA

${ }^{2}$ Columbia University, Dept. Civil Eng., and Eng., Mechanics, New York, NY 10027, USA

Yucca Mountain (YM) in southern Nevada is being considered as a potential site for the long-term disposal of highlevel nuclear waste (HLW). One reason this site has been selected is the presence of a 700-m thick hydrologically unsaturated zone in which the repository is proposed to be located. Low moisture content in the unsaturated zone is considered a favorable condition for the proposed repository, minimizing waste-package degradation rates and the subsequent mobilization and transport of radionuclides. Interaction between the repository and fluid from a perched water zone could result in an increase in the rate of corrosion of the containers and dissolution of the radioactive waste. Further, a perched water zone near the repository could mean accelerated rates of transport of radionuclides through the geologic environment in the event of canister failure. For these reasons, the formation and temporal evolution of perched water bodies in arid environments may be significant considerations in predicting the performance of the proposed HLW repository.

Response model simulations suggest that geologic structure, and infiltration that escapes the evapotranspiration capture zone, are the dominant factors controlling perched water formation in the arid environment at YM. An approach has been developed that uses a two-dimensional 
geologic cross-section of the YM site, with a combination of site specific stratigraphic and hydrologic properties to simulate unsaturated flow conditions for different flux rates. Plausible flux rates are constrained by requirements to form and sustain present- day perched water volumes and simulate observed ${ }^{14} \mathrm{C}$ measurements. Additional constraints include cation and anion hydrochemistry.

This abstract documents work performed at the Center for Nuclear Waste Regulatory Analyses (CNWRA) for the Nuclear Regulatory Commission under Contract NRC-02-93-005. Research was performed on behalf of the NRC Office of Nuclear Materials Safety and Safeguards. The report is an independent product of the CNWRA and does not necessarily reflect the views or regulatory position of NRC.

\section{Risk Assessment Related to Metals: The Role of the Geochemist}

\author{
THORNTON, I., FARAGO, M.B., TRISTAN, E. and WANG, Y. \\ Environmental Geochemistry Research Group, Centre for \\ Environment Technology, Imperial College of Science, \\ Technology and Medicine, London SW7 2BP, UK
}

In developing risk assessment strategies, it is important to realize that metals are present in all components of the environment from both natural and anthropogenic sources. Different metals are present in different mineral and chemical forms with markedly contrasting ranges of solubility and mobility. In the development of regulations, it is important hat metals are not recognized by their mere presence and total concentration in the environment. Much of the metal may be relatively insoluble, of low bioavailability and subject to very slow rates of migration. However, the chemistry of metals may change over time. Sound risk assessment should be based on the best scientific data and evidence available.

Research undertaken by applied geochemists over the past 25 years has progressed from the development of methods for mineral exploration in the terrestrial and marine environment to the application of similar techniques to the understanding of the sources, properties and behavior of metals and their compounds in the surface environment, their pathways and routes of exposure to plants, animals and man. Currently, there is particular emphasis on the implications of metal exposure to human health and in the general area of ecotoxicity.

The paper reviews contributions that can be made by the geochemist in the scientific underpinning of sound risk assessment. These include provision of: (i) information on natural background or baseline concentrations of metals in environmental media; (ii) spatial data on the distribution of metals in the terrestrial environment on both a regional and a national scale through geochemical mapping and in the publication of geochemical atlases; (iii) information on the hehavior of metals in soil/rock systems and in waters in slation to their possible impact on agriculture, land use, drinking-water supplies and human health and (iv) data output from recent studies in the urban environment where man's activities may have changed or masked natural geochemical signatures. The geochemist has also played an active role in the development of analytical techniques, in particular methods for the determination of chemical and mineral forms of metals in soils (speciation) and the significance of these forms in the understanding of metal mobility, bioavailability and human exposure.

Case histories will be presented to illustrate the above points.

\section{Application of Exposure Assessment Models to Shipham, Somerset, UK: An Area with Soil Contaminated by $\mathbf{P b}$ and $\mathbf{C d}$}

\author{
TRISTÁN, E. ${ }^{\prime}$, RAMSEY, M.H.', THORNTON, I.' , and \\ FERGUSON, C. ${ }^{2}$ \\ 'Centre for Environmental Technology and Geology Department, \\ Imperial College, London SW7 2BP, UK \\ ${ }^{2}$ Centre for Research into the Built Environment, The Nottingham \\ Trent University, Nottingham NGI $4 B U, U K$
}

Exposure to $\mathrm{Cd}$ and $\mathrm{Pb}$ has been estimated using four Generic Exposure Assessment Models: CLEA (Contaminated Land Exposure Assessment), HESP 2.10 (Human Exposure to Soil Pollutants), IEUBK (Integrated ExposureUptake Biokinetic Model), and AERIS (Aid for Evaluating the Redevelopment of Industrial Sites). The CLEA model is probabilistic, whereas the others are deterministic. The area selected to evaluate the models is a former $\mathrm{Zn}$ mining village, Shipham, Somerset, UK, that has extremely high concentrations of $\mathrm{Cd}$ (arithmetic mean, $\mathrm{AM}=97 \mu \mathrm{g} \mathrm{g}^{-1}$ ) and very high concentrations of $\mathrm{Pb}$ and $\mathrm{Zn}\left(\mathrm{AM}=2380 \mu \mathrm{g} \mathrm{g}^{-1}\right.$ and $\mathrm{AM}=8870 \mu \mathrm{g} \mathrm{g}^{-1}$ respectively) in soil. Lead, $\mathrm{Zn}$ and $\mathrm{Cd}$ are present mainly in the form of carbonates and the average $\mathrm{pH}$ of the soil is 7.6.

Four exposure situations are simulated for each model; a residence with a garden, a residence without garden, an agricultural area, and a recreational area. Site specific information is used, whenever possible, instead of the default input parameters provided by the models.

The highest intake values of $\mathrm{Pb}$ and $\mathrm{Cd}$ are predicted for the situations of a residence with a garden and an agricultural area, irrespective of which model is employed. Differences between the predictions of the models arise mostly from the algorithms used to estimate soil ingestion and concentration of the contaminant in home-grown vegetables. The main pathway of exposure for $\mathrm{Cd}$ is through the ingestion of home-grown vegetables. For $\mathrm{Pb}$, however, the main pathway of exposure is through the ingestion of soil, except for the situation of residence with a garden, for which the main pathway of exposure is the ingestion of homegrown vegetables. 


\section{Geochemistry of Overbank Sediments in Belgium and Luxembourg: A Way to Assess Environmental Pollution}

\author{
VAN DER SLUYS, J., SWENNEN, R., HINDEL, R., and \\ BRUSSELMANS, A. \\ Geological Survey of Belgium, Jennerstraat 13, B-1000, Brussels, \\ Belgium
}

In a geochemical survey of Belgium and Luxembourg (area about $33,000 \mathrm{~km}^{2}$ ), 66 overbank sites have been sampled. At each site an overbank profile has been dug out and described in detail. The lower overbank sample, usually $>1.5 \mathrm{~m}$ below the surface, was assumed to be pre-industrial. The upper sample was taken $5-25 \mathrm{~cm}$ below the surface, and is supposed to represent deposition over the last century. Changed sedimentary characteristics and the presence of anthropogenic particles often indicate human interference. Finally, an active river sediment was sampled on the site to infer the present-day pollution. The $<125 \mu \mathrm{m}$ fraction of the three sediment samples was analyzed by XRF for 35 elements.

Generally, lower overbank samples show a direct link to the geological substrate and allow an assessment of natural background. Results from the statistical analyses display a clear contrast between the northern part and the southern part of Belgium and Luxembourg, resulting from their different geology. This is especially reflected in the element patterns of $\mathrm{Al}_{2} \mathrm{O}_{3}, \mathrm{MgO}, \mathrm{K} 2 \mathrm{O}, \mathrm{Ga}, \mathrm{Ni}, \mathrm{Rb}, \mathrm{Sc}$ and $\mathrm{V}$ which negatively correlate with $\mathrm{SiO}_{2}$. Furthermore, there is a clear increase in heavy metal and As content from the lower to the upper overbank sediment, as well as to the active river sediment. These elements often correlate well and their correlations become more significant in the anthropogenically influenced samples. The relative increase in element content allows an assessment of the degree of pollution and helps to define those drainage areas where more detailed research is needed.

\section{Comparative Testing Between Conventional and Microencapsulation Approaches in Controlling Pyrite Oxidation}

VANDIVIERE, M. M., SETA, A. K., and EVANGELOU, V.P. Dept. of Agronomy, University of Kentucky, Lexington, $K Y 40546$ OO9I, USA

Oxidation of pyrite in mining waste or overburden is the main source of acid mine drainage (AMD) production, which causes major environmental pollution. Presently, the most common method of controlling AMD problems is through the mixing of alkaline substances, such as limestone, with the AMD-producing materials. However, the effectiveness of this method is still questionable due to iron-armoring potential. Pyrite microencapsulation, utilizing either phosphate or silica coatings, is a novel approach for controlling AMD that is currently under development in our laboratory. The coatings are formed by leaching pyrite with a solution containing $\mathrm{H}_{2} \mathrm{O}_{2}, \mathrm{KH}_{2} \mathrm{PO}_{4}$ or $\mathrm{Na}_{2} \mathrm{SiO}_{3}$, and a $\mathrm{pH}$ buffer. Although under laboratory conditions these approaches have been shown very effective in controlling pyrite oxidation, testing under natural conditions for possible field application are necessary. An outdoor leaching column experiment is currently under observation to evaluate the effects of both conventional and microencapsulation approaches for controlling pyrite oxidation. The experiment consists of control, limestone, phosphate, and silica-coating treatments on mine-spoil samples contained in polyvinyl chloride leaching columns $(0.5 \mathrm{~m}$ high and $15 \mathrm{~cm}$ in diameter) and set up in the field. Preliminary results indicated that, after a 14-month period in the field, application of microencapsulation approaches significantly reduced pyrite oxidation. Among the microencapsulation approaches, the silica coatings seemed to be superior. The average $\mathrm{pH}$ of the leachate samples from the control, limestone, phosphate and silica coatings were $1.6,2.6,4.8$, and 6.5 , respectively, after a 14-month period. The results of these outdoor column leaching experiments have shown that the application of silica coatings could offer an improved solution for the abatement of AMD. However, long term meticulous monitoring and evaluation are still needed.

\section{Baseline Survey of Air Pollution Impacts on Soil and Water Quality in Mpumalanga Province, South Africa}

VAN TIENHOVEN, Mieke, DODDS, Heather A., FEY, Martin V. and WILLIS, James $P$.

Dept of Geological Sciences, University of Cape Town, Rondebosch, 7700, South Africa

The Mpumalanga highveld hosts numerous coal-fired power stations, collieries and heavy industries. Sulfur emissions are of a scale similar to those in Europe and the possibility of acid rain impacts is the focus of much research in the region. Our aim was to consider the impact of air pollution on soil and water quality, as part of a research and monitoring program initiated by the local power company, ESKOM. We sampled 15 soil profiles from uncultivated land in a 20 by $10 \mathrm{~km}$ tract eastward from the 20 -year old Arnot Power Station. Surface water and sediment samples from seven natural pans were also collected. Analyses included total $\mathrm{S}$, phosphate-extractable and water-soluble $\mathrm{SO}_{4}, \mathrm{pH}$, electrical conductivity and other properties related to air pollution. Accurate GPS positioning of the sampling points and a system for preparing composite samples were employed to establish a reliable basis for long-term monitoring. There was some evidence to suggest that the classical linear relationship between total $\mathrm{S}$ and organic $\mathrm{C}$ in soil constitutes a useful basis for detecting the accumulation of $S$ from atmospheric sources, with highveld soils showing an enhanced intercept value relative to that for soils remote from sources of atmospheric pollution. Ion chromatography was shown to be a more reliable method than turbidimetry 
for determining labile $\mathrm{SO}_{4}$ in dilute phosphate extracts of soils. No clear gradient in $\mathrm{S}$ accumulation could be found over a $20-\mathrm{km}$ traverse from the power station.

\section{Contamination of Ground Water in Diverse Hydrogeochemical Environments, SE Hungary}

\author{
VARSÁNYI', Irén and Ó.KOVÁCS ${ }^{2}$, Lajos \\ 'Institute of Mineralogy, Geochemistry and Petrography, Attila \\ József University, H-6701 Szeged, Pf. 651, Hungary \\ ${ }^{2}$ Hungarian Geological Survey, H-1440 Budapest, Pf. 17, \\ Hungary
}

Southeastern Hungary is an area with extensive agricultural activity. The source of water supply over this area is shallow ground water. In this rural environment the unconfined aquifer is vulnerable; possible sources of contamination are fertilization and livestock.

The study area comprises three different topographic levels with different geological properties. One of them is located in the region between the Rivers Danube and Tisza. Its surface is covered by $100-150 \mathrm{~m}$ of windblown sand and loess underlain by sand, silt and loam sediments deposited by the River Danube. Toward the east, the next level is the River Tisza valley covered by a Holocene floodplain. The elevation decreases by $40-50 \mathrm{~m}$ from west to east, that is from the sand and loess hills between the Rivers Danube and Tisza, to the Tisza valley. While this region is the discharge rea of a medium-depth water-flow system situated in the River Danube deposits, the previous one represents the recharge area of the same. The third topographic level located eastward from the River Tisza valley is represented by Pleistocene floodless terraces, consisting mainly of loess. Its surface is several meters higher than that of the River Tisza valley. From a hydrologic point of view, it is presumably the discharge area of a water-flow system at great depth.

The primary objective of this study was to investigate the effect of the different geological environments on the chemical composition of shallow ground water to determine the degree of vulnerability in the different parts of the study area. Vertical profiles of the dissolved chemical components were used for predicting the pollution risk to ground water from agricultural activities.

Nitrate and chloride were chosen as the basic hydrochemical indicators of pollution. The most polluted area turned out to be the River Tisza valley. Furthermore, due to the important role played by redox processes in the chemistry of the shallow ground water studied, the nitrate and chloride contaminations reach different depths: chloride as a conservative component remains in the water deeper than $55 \mathrm{~m}$, whereas nitrate disappears at a depth of about 20 $\mathrm{m}$. On the other hand, the pollutants reach greater depths in ie recharge area (the one between the Danube and Tisza) than in the discharge area (Tisza valley), as expected. In the third area (the one east of the Tisza) the influence of deep $(>100 \mathrm{~m})$ ground waters dominates.
Inductively Coupled Plasma - Atomic Emission Spectrometry Used in Analysis of Pollutants from an Area With Non-Ferrous Extraction and Ore-Processing

VIMAN, Vasile', MIHAI, Mihaela' , ARDELEAN, Gavril', VATCA, Gheorghe ${ }^{2}$

'North University of Baia Mare, dr. Victor Babes 62A, Baia Mare, ROMANIA,

fax: 40-062-422173, e-mail: vimanv@univer.ubm.ro

2"Quartz" Company for Geological Exploration, Baia Mare, ROMANIA

Within the studied area, there are processing plants for extracting, concentrating and processing ores that contain: $\mathrm{Pb}, \mathrm{Cu}, \mathrm{Zn}, \mathrm{Mn}, \mathrm{Fe}, \mathrm{Al}, \mathrm{Bi}, \mathrm{Co}, \mathrm{Cd}, \mathrm{As}, \mathrm{V}$, and Mo. In each stage of the process, particulate material is released to the environment. These particulates may settle from the air or remain suspended; the result is widespread pollution of air, soil and plants.

$\mathrm{Pb}, \mathrm{Zn}$, and $\mathrm{Mn}$ were determined in samples of sedimentable airborne particulates, from soil samples and from plant samples (nettle and spinach), using Inductively Coupled Plasma - Atomic Emission Spectrometry (ICPAES). This method allows determination of concentrations with 3-4 orders of magnitude of variation. Samples were dissolved with $\mathrm{HCl}, \mathrm{HNO}_{3}$ and $\mathrm{HF}$ in a microwave oven (CEM MDS 2000 type). Experimental determinations were made by a sequential spectrometer (BAIRD ICP-2070), watching $\mathrm{Pb}, \mathrm{Zn}$ and $\mathrm{Mn}$ concentrations in sedimentable particulates, soil, nettle and spinach. The samples were collected $4 \mathrm{~km}$ from the principal source of the pollution.

Experimental results $\left(\mathrm{mg} \mathrm{kg}^{-1}\right)$ are presented in the following Table.

\begin{tabular}{llll} 
Element Samples & $\mathrm{Pb}$ & $\mathrm{Zn}$ & $\mathrm{Mn}$ \\
Sedimentable particulates & 20,000 & 13,100 & 1,440 \\
Soil & 490 & 287 & 188 \\
Nettle & 460 & 1,030 & 830 \\
Spinach & 190 & 1,300 & 200 \\
\hline
\end{tabular}

The results show that elements have concentrations higher than the maximum allowed limit or typical concentration in plants. High concentrations in particulates and soil, at relatively short distances from the source, can be explained by existence of heavy metals in sulfides, sulfates, oxides and carbonates. Concentrations in plants, sometimes higher than in soil, are explained by uptake of metals by the plants and deposition of airborne particulates on leaf surfaces. The mechanisms by which heavy metals accumulate in soil and plants are very complex and are influenced by many factors, including: nature of chemical residence of metals, quantity of organic matter in soil, $\mathrm{pH}$ of soil and plant type. 


\section{Trace Elements in the Kuskokwim River, Alaska}

WANG, Bronwen

U.S. Geological Survey, 4200 University Dr., Anchorage, AK 99508

The Kuskokwim River drainage in southwest Alaska includes the Kuskokwim mineral belt, a highly mineralized region known to have elevated trace-element concentrations in the bedrock. Mercury deposits occur in localized areas within the drainage and some deposits are immediately adjacent to the river. Previous studies found elevated $\mathrm{Hg}$ concentrations of bed sediments near historic $\mathrm{Hg}$ mines. This study investigates the transport and loads of trace elements in the Kuskokwim River and the influence of the lithologic changes on trace-element loads. Water, suspended sediment, and bed sediments were sampled at locations on the Kuskokwim River between McGrath and Bethel in June 1997 using a lagrangian sampling scheme. Additional samples were collected at the following Kuskokwim River tributaries: Stony River, Holitna River, Crooked Creek, and Aniak River as well as near Red Devil, a historic $\mathrm{Hg}$ mine. Samples were analyzed for selected trace elements including $\mathrm{Cu}, \mathrm{Zn}, \mathrm{Cr}, \mathrm{Cd}, \mathrm{Ag}, \mathrm{As}, \mathrm{Sb}, \mathrm{Se}$, and $\mathrm{Hg}$. Samples were collected to (1) estimate instantaneous trace-element flux from trace-element concentrations of dissolved and suspended sediment and from discharge, (2) evaluate coupling the new bed-sediment trace-element data with historical sediment concentration and discharge data to determine annual flux, and (3) evaluate changes in trace-element concentration relative to changes in the regional bedrock.

\section{Environmental Geochemistry of Rare Earth Elements in Main Type Soils in China}

WANG, Lijun', ZHANG, Shen', GAO, Xiaojiang', LIU, Shujuan', WANG, Yuqi ${ }^{2}, S U N$, Jingxin ${ }^{2}, C H E N$, Hongmin ${ }^{2}$

'Institute of Geography, Chinese Academy of Sciences, Beijing 100101, China

${ }^{2}$ Institute of High Energy Physics, Chinese Academy of Sciences, Beijing 1001080, China

Content, distribution pattern and speciation of rare earth elements (REE) in six type soils such as latesol (tropical zone), red earth (middle subtropical earth), yellow-brown soil (Northern subtropical earth), cinnamon soil (warm temperate zone), leached chernozem (temperate zone) and albic bleached soil (temperate zone) in China, were determined with instrumental neutron activation analysis (INAA). The REE contents are different in various soils, ranging from 86.3 to $251.9 \mathrm{mg} \mathrm{kg}^{-1}$. The REE distribution patterns of soils are consistent with the REE features of their parent rocks. In all six soils, REE mainly exist in residual form, and with the increase of atomic number, intermediate REE (IREE) have lower proportions of residual form than light REE (LREE) and heavy REE (HREE). For the unstable forms, water soluble form has the lowest proportion, the proportion of exchangeable form, carbonate and specific adsorption form are also lower. Proportions of Fe-Mn oxides form in soils decrease gradually from the southern region to the northern region of China. Proportions of bound organic matters are higher and follow the order: Albic bleached soil $>$ leached chernozem $>$ red earth $>$ latesol > yellow-brown soil > cinnamon soil.

\section{Remediation of High-Fluoride Ground Waters from Arid Regions Using Heat- Treated Soils: A Column Experiment Study in Xinzhou, China}

\author{
WANG, Yanxin, XIMING, Yuan, and HUAMING, Guo \\ China University of Geosciences, Wuhan, 430074, PR China
}

Fluorosis is the most widespread endemic disease in China. It was estimated that more than 40 million Chinese people are victims of endemic dental fluorosis, which is largely related to long-term intake of high-fluoride ground waters. Most of these waters occur in the semi-arid and arid regions of northwestern China. Cost-effective remediation of highfluoride ground waters is urgently needed for the sustainable social and economic development of these regions.

In the present study, three types of Cenozoic soils were used as fluoride-removing materials: one is red soil and the other two are loess. The water samples used in our column experiments include three drinking waters and one thermal water that are representative of the high-fluoride ground waters widely developed in Xinzhou, a rift basin of the Fengwei Graben in northwestern China. The fluoride concentrations in this basin range from $1.3 \mathrm{mg} \mathrm{L}^{-1}$ to $5.0 \mathrm{mg}$ $\mathrm{L}^{-1}$. To increase the permeability and exchange capacity of the soil materials, after being soaked in distilled water for 48 hr., they were separately put into a muffle furnace for $2 \mathrm{hr}$. The heat-treated soil materials are then ground, sieved and filled either in glass tubes or in PVC columns. Afterwards, hydraulic conductivity and working exchange capacity measurements, as well as fluoride-removal experiments, were conducted.

Our results show that the heat-treated Cenozoic red soil, with grain size $0.1-1.0 \mathrm{~mm}$, is a permeable and powerful fluoride-removing material with hydraulic conductivity values between $0.05 \mathrm{~cm} \mathrm{~s}^{-1}$ and $0.11 \mathrm{~cm} \mathrm{~s}^{-1}$ and working exchange capacity between $89.1 \mathrm{mg} \mathrm{kg}^{-1}$ and $148 . \mathrm{mg} \mathrm{kg}^{-1}$. The optimal heating temperature is about $400^{\circ} \mathrm{C}$. Using $12.5 \mathrm{~kg}$ of the material with grain size $0.25-1.0 \mathrm{~mm}$, more than 300 liters of the high fluoride ground waters from Xinzhou were treated before the effluent's fluoride concentration of the column experiment reached $1.0 \mathrm{mg} \mathrm{L}^{-1}$. Some preliminary studies on the mechanism of the material's fluoride-removing capacity and regeneration procedures using acids, alkali, $\mathrm{Fe}$ and $\mathrm{Al}$ salts have also been made. 


\section{Exposure of Children to Lead in the Home Environment-A Comparative Study in Shanghai and Birmingham}

\author{
WANG, Yong, THORNTON, Iain, and FARAGO, Margaret \\ Environmental Geochemistry Research Group, Centre for \\ Environmental Technology, Imperial College of Science, \\ Technology, and Medicine, London, SW7 2BP, UK
}

Blood $\mathrm{Pb}$ concentrations in children are reported to have significantly declined in the developed world since mid 1970. This decline has been attributed to successful reduction measures in $\mathrm{Pb}$ emissions. In contrast, elevated blood $\mathrm{Pb}$ concentrations are currently receiving attention in developing countries in which rapid economic growth is leading to increasing $\mathrm{Pb}$ consumption. However, there is little quantitative information about $\mathrm{Pb}$ exposure in children in these areas and of the implications to children's health. Shanghai, China and Birmingham, UK were selected for a comparison of present day $\mathrm{Pb}$ exposure in a rapidly developing country to a developed country in the west. Surveys were implemented within the two cities in 1995 and 1996. In Shanghai, while concentrations of $\mathrm{Pb}$ were found to be relatively low in garden soils and roadside dusts (geometric mean values of $55 \mu \mathrm{g} \mathrm{g}^{-1}$ and $196 \mu \mathrm{g} \mathrm{g}^{-1} \mathrm{~Pb}$, respectively) elevated $\mathrm{Pb}$ concentrations were recorded in the floor dusts taken from 65 houses (geometric mean value of $633 \mu \mathrm{g} \mathrm{g}^{-1}$ $\mathrm{Pb}$ ). In contrast, a significant reduction in $\mathrm{Pb}$ levels has been found in dusts in inner city Birmingham over a 12-year period. The geometric mean values of $\mathrm{Pb}$ in house dusts fell from $311 \mu \mathrm{g} / \mathrm{g}$ in 1984 to $133 \mu \mathrm{g} \mathrm{g}^{-1} \mathrm{~Pb}$ in 1996, and dust- $\mathrm{Pb}$ loading fell from 42 to $30 \mu \mathrm{g} \mathrm{m}^{-2}$. The updated US-EPA IEUBK (0.99d) model for exposure of children to $\mathrm{Pb}$ was used to predict exposure and blood $\mathrm{Pb}$ levels for two-year old children in both locations. Results indicate that the total $\mathrm{Pb}$ exposure declined in Birmingham from $30 \mu \mathrm{g} \mathrm{day}^{-1}$ in 1984 to $21 \mu \mathrm{g} \mathrm{day}^{-1}$ in 1996. In parallel, blood $\mathrm{Pb}$ concentrations declined from a geometric mean value of $11.4 \mu \mathrm{g}$ $\mathrm{dl}^{-1}$ in 1984 to $8.1 \mathrm{\mu g} \mathrm{dl}^{-1}$ in 1996. It is concluded that the reduction in the intake of $\mathrm{Pb}$ from dusts and diet would have contributed principally to this decline. In Shanghai, however, a high exposure of $58.3 \mu \mathrm{g} \mathrm{day}^{-1}$ was predicted. This suggests a potential risk to children's health and may be attributed to increasing $\mathrm{Pb}$ emissions from traffic in a time of rapid economic growth.

\section{The Utilization of High Spectral Resolution Imagery and Field Spectra for the Detection and Monitoring of Mining Sites}

\author{
WAWRZYNSKI, Alecia L., MARRS, Ronald W. \\ Department of Geology and Geophysics, University of Wyoming, \\ ?.O. Box 3006, Laramie WY 82071
}

The environmental effects of mining can be detected and monitored using high spectral resolution systems to examine the interaction of rocks, soils, and vegetation. Field spec- troscopy data and AVIRIS (Airborne Visible Infrared Imaging Spectrometer) data were used to map alteration and areas of contamination related to mining in the South Pass Atlantic City district of Wyoming. Mining in this area has disturbed soils and vegetation, and modified topography. High spectral resolution imaging systems utilize the characteristic response of atoms within a mineral to electromagnetic radiation for identification. Exposing the mineral to electromagnetic radiation in the visible through mid-infrared wavelengths and recording the response in numerous narrow bands produces spectra which are often unique for selected minerals. Alteration minerals (in particular clays), carbonates, and iron hydroxides are particularly responsive in the mid-infrared region.

Economic minerals in the South Pass - Atlantic City district occur in association with hydrothermal alteration localized in shear zones and in structurally thickened zones. Subsequent mining and processing have produced tailings that have been weathered and transported. Analysis of the AVIRIS imagery provided a way to map the surface disturbance, the limit of the mineralization, and the subsequent redistribution of waste products. Field data were collected using a hand held mid-infrared spectrometer to provide reference spectra and field verification. High spectral resolution imaging offers a quick and easy mechanism for mapping and monitoring mineralized areas and mines, which can help minimize environmental damage.

*Funded by Wyoming Space Grant Consortium and Planetary and Space Science Center, NASA Grant \#NGT-40050

\section{Trace Metal Adsorption onto Schwertmannite (Iron Oxyhydroxysulfate) in Acid Mine Drainage Systems}

WEBSTER Jenny G., SWEDLUND Peter J., and WEBSTER Kerry S. Institute of Environmental Science and Research (ESR), 17 Kelly St., Auckland, New Zealand

Hydrous ferric oxides (HFO) have the capacity to adsorb trace metals in aquatic environments, thereby regulating dissolved metal concentration and toxicity. The adsorption of the trace metals $\mathrm{Cu}, \mathrm{Pb}, \mathrm{Zn}$ and $\mathrm{Cd}$ onto pure $\mathrm{HFO}$ has been compared to adsorption onto synthetic and natural schwertmannite, a poorly crystallized oxyhydroxysulfate of iron occurring in acid mine drainage (AMD) systems. At the sorbent/sorbate ratios typical of AMD systems, $\mathrm{Pb}$ adsorption was inhibited on natural schwertmannite relative to pure $\mathrm{HFO}$, while $\mathrm{Cu}, \mathrm{Zn}$ and $\mathrm{Cd}$ adsorption was enhanced.

The response of metal adsorption edges (adsorption as function of $\mathrm{pH}$ ) to changes in solution and surface chemistry, indicated that the surface interaction of metals with adsorbed sulfate was an important factor affecting adsorption onto synthetic schwertmannite. Bulk physical or chemical differences in the synthetic oxide substrates did not appear to influence metal adsorption. Adsorption of $\mathrm{Pb}$ occurred under relatively low $\mathrm{pH}$ conditions, which strongly favored sulfate adsorption, and was adversely affected by sulfate 
competition for binding sites. Adsorption of $\mathrm{Cu}$ and $\mathrm{Zn}$ in a higher $\mathrm{pH}$, less competitive, regime was enhanced by sulfate adsorption which changed electrostatic conditions at the oxide surface. At still higher $\mathrm{pH}, \mathrm{Cd}$ adsorption was unaffected by sulfate which had been mainly removed from the oxide surface by desorption.

Adsorption of $\mathrm{Cu}, \mathrm{Zn}$ and $\mathrm{Cd}$ onto natural schwertmannite was considerably enhanced relative to synthetic schwertmannite. This was inconsistent with observed differences in surface area and crystallinity between synthetic and natural schwertmannite sorbents. Nor could the enhancement be explained in terms of additional adsorbing oxide, silica or clay surfaces. The possibility that enhancement was due to metal interaction with an organic component of the natural oxide, perhaps bacterial cells or adsorbed humic or fulvic acids, is currently under investigation.

\section{Possibility of Geological Disposal of $\mathrm{CO}_{2}$ : Results from Geochemical Modeling}

\author{
WEN, Dongguang', and ZENG, Jianhua ${ }^{2}$ \\ 'Bureau of Geological Survey, Ministry of Geology and Mineral \\ Resources, Xisi, Beijing, I00812, PR China \\ ${ }^{2}$ Department of Information, People's University of China, \\ Beijing, I00872, PR China
}

Fossil carbon (coal, oil, and natural gas) supplies about $90 \%$ of the world's energy, and a great quantity of $\mathrm{CO}_{2}, \mathrm{CO}, \mathrm{SO}_{x}$, and $\mathrm{NO}_{x}$ is emitted during fuel burning. $\mathrm{CO}_{2}$ is one of the most important greenhouse gases, and one of the greatest threats to changing atmospheric temperature and acidity of rainfall.

It is known that $\mathrm{CO}_{2}$ can react with various carbonate and aluminosilicate minerals in ground-water systems. This paper has simulated the different water-rock systems at different $\mathrm{CO}_{2}$ partial pressures and temperatures with the geochemical computer code PHREEQE (Parkhurst, et al., 1985). It is found that different water-rock interaction systems have different ability of fixing $\mathrm{CO}_{2}$, and albite-microcline-muscovite-quartzdolomite-calcite- $\mathrm{CO}_{2}-\mathrm{H}_{2} \mathrm{O}$ system has large capacity of fixing $\mathrm{CO}_{2}$. Modeling results of the albite-microcline-muscovitequartz-dolomite-calcite- $\mathrm{CO}_{2}-\mathrm{H}_{2} \mathrm{O}$ system at $50-200{ }^{\circ} \mathrm{C}$ and $10^{3}-10^{1}$ atm $\mathrm{CO}_{2}$ partial pressures in a closed system show that more $\mathrm{CO}_{2}$ absorption increases with increasing $\mathrm{CO}_{2}$ partial pressures and decreasing temperature. One $\mathrm{km}^{2}$ of the waterrock system with $1 \mathrm{~m}$ thickness and $10 \%$ porosity can absorb approximately $1.05 \times 10^{4}$ tons of $\mathrm{CO}_{2}$ at $10^{-2}$ atm of $\mathrm{CO}_{2}$ partial pressures at $80^{\circ} \mathrm{C}$.

Possibility of the above-mentioned water-rock interaction has been studied (Shen, et al., 1995). Consequently, geological disposal of $\mathrm{CO}_{2}$ is theoretically possible.

Parkhurst, D. L., Thorstenson, D. C., Plummer, L. N. revised and reprinted - 1985. PHREEQE-A computer program for geochemical calculations. USGS Water Resources Investigations Report 80-96. Shen Z., Wen D., Zhong Z., 1995. Genesis of alkali deposit in the Biyang depression of Nanxiang basin in Henan province, P.R. China. In Kharaka and Chudaev (eds.), Proceedings of the 8th International Symposium on Water-Rock Interaction, Vladivostok, Russia, pp. 653-655.
Recovery of Brown Trout (Salmo Trutta) and Brook Trout (Salvelinus Fontinalis) Populations in the Eagle River, Colorado, U.S.A., During and Following CERCLA Recovery Actions

\author{
WOODLING, John D., HORN, Barbara J., and PARACHINI, \\ Richard. \\ Colorado Division of Wildlife, 6060 Broadway, Denver, \\ Colorado, 80216, USA
}

The number of individuals and age classes of brown trout (Salmo trutta) significantly increased in a $19-\mathrm{km}$ reach of the Eagle River, Colorado, U.S.A., from April 1990 to April 1996 following initiation of a CERCLA consent degree restoration program in 1989. Prior to the continuing restoration actions, $\mathrm{Cd}$ and $\mathrm{Zn}$ seasonally exceeded acute and/or chronic toxic concentrations in this $19-\mathrm{km}$ stream reach due to a variety of discharges from an inactive mine complex owned by Viacom International, Inc. An annual spring monitoring program demonstrated that the increases in brown trout numbers and age classes did not occur gradually through the years 1990 to 1996 . Instead, there was a large step increase correlated to the year 1994 in which Cd concentrations were reduced. As of April 1996, the $\mathrm{Zn}$ levels within the $19-\mathrm{km}$ reach were still elevated relative to both control sites and acutely toxic concentrations. With one exception, brown trout numbers remained reduced compared to control sites. Brook trout (Salvelinus fontinalis) numbers within the $19-\mathrm{km}$ reach were higher than at control sites from 1994 to 1996, perhaps due in part to a higher tolerance of $\mathrm{Zn}$ in this species compared to brown trout. A qualitative aquatic macroinvertebrate sampling program demonstrated a gradual increase in the number of taxa present in the $19-\mathrm{km}$ reach. The increase in aquatic macroinvertebrate taxa was not associated with decreases in water column $\mathrm{Cd}$ and $\mathrm{Zn}$, but with high spring flows in the summer of 1995 that removed a layer of metal precipitates that had cemented the stream substrate.

\section{Environmental and Hydrogeological Problems Caused by Overexploitation of Geothermal Ground Water in Coastal Cities of South-Eastern China: A Case Study in Fuzhou Basin}

YAO, Hua ${ }^{n 1}$, and LIN, Zhixun ${ }^{2}$

'Department of Resources and Environmental Engineering, Fuzhou University, China

${ }^{2}$ Fujian Geological Institute, P. R. China. (Present address: Environmental Geology, Institute of Earth Sciences, Uppsala University, Sweden)

Following the economic development of coastal cities in south-eastern China in the late 1970's, overexploitation of geothermal ground water in the area has caused environmen- 
tal and hydrogeological problems. Fuzhou Basin has been investigated since the mid 1980's. Overexploitation has resulted in the decline of the ground-water level and subsequently the change in hydraulic conditions in the groundwater field. The hot ground-water level has declined by 10 $35 \mathrm{~m}$. The elevation of the dome-shaped ground-water mound in the center of the field gradually decreased, and a funnel-shaped depression has subsequently formed. Groundwater flow towards the central ground-water depression causes an increase in total dissolved solids (TDS), As, Fe, $\mathrm{Mn}, \mathrm{Pb}, \mathrm{SO}_{4}, \mathrm{Cl}, \mathrm{HCO}_{3}, \mathrm{NO}^{3-}, \mathrm{NH}^{4+}$, and phenol in the geothermal ground water; results in a decline in the water temperature by a rate of $1.14-1.38{ }^{\circ} \mathrm{C} \mathrm{a}^{-1}$. Accompanying the decline in the ground-water level, the ground has subsided by more than $150 \mathrm{~mm}$, and locally the ground has subsided $313-414 \mathrm{~mm}$. The subsidence rate increases from less than $20 \mathrm{~mm} \mathrm{a}^{-1}$ in the 1960's to $50 \mathrm{~mm} \mathrm{a}^{-1}$ in the 1990's.

\section{Modern Shallow-Water Fe-Mn Concretions as an Indicator of the Contamination of Marine Environments: A New Type of Marine Environmental Geochemical Monitoring}

\section{ZHAMOIDA Vladimir A.}

All-Russia Geological Institute (VSEGEI), St. Petersburg, RUSSIA

The formation of shallow-water Fe-Mn concretions occurs worldwide. The influence of these active biogeochemical processes on the quality of near-bottom environments is believed to be especially significant for the water basins, such as the Baltic Sea, located in areas with moderate climate and intense anthropogenic activity.

The results of our investigations show the influence of environmental changes on several types of concretions:

1. Natural trap cleaning near-bottom waters of:

1.1. The main ore-elements $(\mathrm{Mn}, \mathrm{Fe}, \mathrm{P})$ : concretion fields of the Gulf of Finland accumulate the river input of $\mathrm{Mn}$ for 4400 years.

1.2. Minor elements: in the small spheroidal concretions and in the surficial micro-layers of growing plate concretions marked increases of the contents of some heavy metals $(\mathrm{Pb}, \mathrm{Zn}, \mathrm{Cu}$, etc.) was fixed. This increase is explained by the input of anthropogenically derived toxic metals to the Baltic Sea.

1.3. Radioactive elements: concretions are enriched in radioactive elements, natural $-{ }^{226} \mathrm{Ra}$, and technogenic ${ }^{137} \mathrm{Cs}$.

2. Amounts of total organic and bituminoids decrease in the near-bottom water and sediments within the concretion fields.

3. Changing of the $\mathrm{Mn}^{4+} / \mathrm{Mn}^{2+}$ ratio in the concretions can smooth the redox fluctuations in the near-bottom waters.

r. potential hazard of re-pollution of the near-bottom water, as a result of concretion dissolution.

The average growth rate of Baltic concretions is about 3-6 $\mathrm{mm} /$ century. The age of concretions is limited by 500 years and comparable with the history of technogenic input to the sea.

Usually the environmental geochemical monitoring in the sea basins is limited by investigations of the recent mud sediments, more often reduced. We suppose, that due to high growth rates and sorption properties of the oxidized shallow-water Fe-Mn concretions, some times they can fix several types of pollutants and react to the changes of hydrochemical conditions more actively than the mud sediments. These changes and character of contamination could be recognized by investigations of the distribution of chemical composition within the slices of concretions or within different size fractions of concretions.

\section{Lead in the Environment, China}

\section{ZHANG Fuquing', ZHANG, Xuelin ${ }^{2}$}

'AWOKE Dental Clinic No. 2 Building West 7 Road, Xin Fu District, Fushun City 113006 Liaoning Province, China ${ }^{2}$ Changchun Institute of Geography, Chinese Academy of Sciences, Changchun 130021 China

This paper has reviewed the aspect and progress of lead in environment, especially, urban environment in China for the recent years. In China, limited available information indicates that the following 6 sources appear to account for the most significant lead exposures in children in: 1 . industrial emissions, such as mining, smelting, refining, manufacturing, home-based village lead industries are remarkable lead sources in the countryside of China; 2 . leaded gasoline; China used the leaded gasoline extensively, with a leaded content up to $0.78 \mathrm{~g} \mathrm{~L}^{-1} ; 3$. lead contaminated toys and stationery for children; 4 . Contamination of the home environment produced by lead exposed parents; 5 . Contamination of home environment produced by household coal combustion; 6. Food and traditional medicine.

Comprehensive epidemiological data in China related to the prevalence of childhood lead poisoning is not available. However, these data suggested that this poisoning may be widely pervasive as a result of rapid industrialization and use of the leaded gasoline. It has been reported in the elevated blood $\mathrm{Pb}$ level in children from the different areas in the country. Children resided in industrial and busy traffic areas have 21.8-67.9 $\mathrm{g} \mathrm{dl}^{-1}$ of mean blood levels, in which the percentage of blood $\mathrm{Pb}$ values above $10 \mu \mathrm{g} \mathrm{dl^{-1 }}$ range from 64.9-99.5\% in some cities of China. Government and scientists in China have thus focused on the problem of $\mathrm{Pb}$ contamination. 


\section{Environmental Geochemical Features in the Coal Mine Areas in China}

\author{
ZHANG, Licheng, and WEI, Chaoyang \\ Institute of Geography, Chinese Academy of Sciences, Beijing \\ 100101
}

Based on the investigation and analyses of the drainage water, coal and gangue of the typical coal mines distributed in the different geographical zones of the state, the following results are shown: 1) the salt content in the drainage water of China's coal mines are in great difference, from $364 \mathrm{mg} \mathrm{L}^{-1}$ to $4166 \mathrm{mg} \mathrm{L}^{-1}$, about $40 \%$ of which are greater than 1000 $\mathrm{mg} \mathrm{L}^{-1} ; 2$ ) the content of $\mathrm{SO}_{4}{ }^{2-}$ is high, most often as the dominant negative ions; 3 ) the hardness of drainage water changes from soft (4 -8 German degree) to very hard (>30 German degree); 4) most of the drainage waters are a bit alkaline with the $\mathrm{pH}$ from 8.0 to 8.9 , when sulfur content of coal is above $5 \%$, the drainage water appears to be acid. From the analytical results of more than ten elements, it can be seen that the content of As lies in $0.013-0.08 \mu \mathrm{mol} \mathrm{L} \mathrm{L}^{-1}$, with the greatest $0.152 \mu \mathrm{mol} \mathrm{L}^{-1}$. Whereas the contents of $\mathrm{Mn}$ are high with large variations, from 0.382 to $311 \mu \mathrm{mol}$ $\mathrm{L}^{-1}$, median value is $3.08 \mu \mathrm{mol} \mathrm{L} \mathrm{L}^{-1}$. The variation of $\mathrm{Fe}$ is from 3.4 to $5490 \mu \mathrm{mol} \mathrm{L} \mathrm{L}^{-1}$, median value is $4.04 \mu \mathrm{mol} \mathrm{L}{ }^{-1}$. Also, the variation of $S$ and $F$ which contribute greatly to pollution, the $S$ content in the coal of north regions are mostly lower than $1.0 \%$, while higher than $1.0-2.0 \%$ in the south China. According to the analyses in some coal mines, the average $\mathrm{F}$ content in the coal is $10,200 \mu \mathrm{mol} \mathrm{L} \mathrm{L}^{-1}$, with a rather large range between 789 and $124,000 \mu \mathrm{mol} \mathrm{L}^{-1}$.

\section{Uranium and Uranium Isotopes as Tracers of Nutrient Addition: A Case Study in South Florida}

\author{
ZIELINSKI, Robert A., SIMMONS, Kathleen R., and OREM, \\ William $H$. \\ U.S. Geological Survey, Mail Stop 973, Denver Federal Center, \\ Denver, CO 80225
}

Drainage water from agricultural areas south of Lake Okeechobee is the suspected carrier of excess phosphorous (P) to portions of the Everglades of South Florida. The addition of fertilizer-derived $P$ to Everglades peat can be assessed through the monitoring of fertilizer-derived uranium (U). Phosphate fertilizer typically contains 20-200 $\mathrm{mg} \mathrm{kg}^{-1} \mathrm{U}$ that correlates with $\mathrm{P}$ content and that originates from the mined phosphate rock. Fertilizer $U$ also retains a distinctive, rock-like ${ }^{234} \mathrm{U} /{ }^{238} \mathrm{U}$ alpha activity ratio (AR) of $1.00 \pm 0.05$. These characteristics provide a distinctive $U$ based signature of fertilizer that is potentially traceable in low-U environments such as Everglades peat. Six peat cores from areas variably impacted by excess $P$ were sampled to determine the depth-wise distribution and the apparent lateral dispersion of fertilizer-derived U. Peat closest to canals carrying agricultural runoff sorbs enough $\mathrm{U}$ to produce anomalous bulk uranium concentrations of $>1.0 \mathrm{mg}$ $\mathrm{kg}^{-1}$ in shallow horizons. In these horizons the easilyexchangeable $\mathrm{U}$ that is soluble in $0.1 \mathrm{M} \mathrm{NaHCO}_{3}$ has an isotopic composition that is consistent with a fertilizer origin $(\mathrm{AR}=0.97$ to 1.03$)$. In contrast, peat samples from unimpacted sites contain $<0.2 \mathrm{mg} \mathrm{kg}^{-1} \mathrm{U}$ and have $A R$ values of 1.05 to 1.22 in the exchangeable fraction. Some peat horizons of intermediate depth and $U$ content have exchangeable $U$ with $A R$ values that suggest a mixture of natural and fertilizer-derived $U$. Isotopic evidence for fertilizer addition to a cultivated field was equivocal because of poor contrast with background $A R$ values of the local soil $(A R=1.03$ to 1.05$)$. Measurements of $A R$ in agricultural runoff are pending.

\section{Methods and Evaluation Models for Standardized Risk Assessment of Gold Mining Waste Sites in South Africa.}

\author{
ZIERDT, K.', De VILLIERS, A.B. ${ }^{2}$, COETZEE, $H^{3}$ \\ 'Dept. of Geological Sciences, Univ. of Cape Town, Rondebosch \\ 7700, South Africa \\ ${ }^{2}$ Dept. of Geography and Environmental Studies, Univ. of \\ Potchefstroom, P Bag X6001, Potchefstroom 2520, South Africa \\ ${ }^{3}$ Council for Geoscience, Geological Survey of South Africa, $P$ \\ Bag X112, Pretoria 0001, South Africa
}

A large quantity of water related data for the Carletonville gold mining area has accumulated. Unfortunately, the information was and is being collected independently by different governmental and private agencies. The uncoordinated collection, storage, retrieval and availability of data is a major difficulty. Few comprehensive reviews are available, nor is there a systematic prioritization of the existing and potential problems. Radionuclides and toxic metals are high risk pollutants which cause severe environmental and health related problems. The potential risk to the environment was only identified during the early seventies. Neither the present risk nor the pollution potential of these agents is fully appreciated. The Carletonville Region was used for a pilot study and is the basis for developing a source orientated South African Environmental Management System (SEMS), which can be used by the mining industry to determine and monitor major pollution sources. The KatBoSystem, which was developed for the German copper mining region, is one of the methods used for creating the SEMS. This system develops methods for classifying the nature and extent of pollution sources. The ultimate goal of the SEMS is the determination of criteria and methods needed to record and interpret environmental pollution on a regional scale. The SEMS can also be used as a training module for universities and training institutions in the South African Developing Countries region as a contribution to sustainable economic development. 


\section{The South African Environmental Management System (SEMS) —Carletonville Gold Mining Area as a Pilot Study.}

\author{
ZIERDT, K.', De VILLIERS, A.B. ${ }^{2}$, COETZEE, $H .^{3}$ \\ 'Dept. of Geological Sciences, University of Cape Town, \\ Rondebosch 7700, South Africa \\ ${ }^{2}$ Dept. of Geography and Environmental Studies, University of \\ Potchefstroom, P Bag X6001, Potchefstroom 2520, South Africa \\ ${ }^{3}$ Council for Geoscience, Geological Survey of South Africa, $P$ \\ Bag X112, Pretoria 0001, South Africa
}

Investigation, remediation and monitoring of environmental pollution of large areas is one of the most difficult and cost intensive problems experienced by industrialized countries. The prioritization of environmental problems needs a timely and accurate investigation over a short period of time. South African mines are obliged by law to provide and implement an Environmental Management Program (EMPR). The major problem of these EMPRs is the fact that each individual mine is only responsible for its own property. The only real solution to the problem is to see the mine in its context to the surrounding environment in a holistic manner. This will take cognizance of the individual mine as well as of the region. The SEM System will provide its users with a user friendly, proven data base that includes information on methods, sites, analytical results and a quick reference which will enable the user to solve problems through the use of sources, subjects, etc. All available data is filed in a register which is flexible in its design in order to accommodate new information on a real time basis. SEMS is a tool to identify the role of all anthropogenic factors associated with each type of pollution. It can isolate the specific source and the spread of pollution can be predicted. SEMS will provide the means to test, check and prove assessments, create programs for the investigation of contaminated sites and provide standards for contractors. It will also make it possible to assess the present as well as the possible future value and use of sites and also provide a coordinated system for administration.

\section{Interdisciplinary Training Modules in Mining and the Environment_Case Study On The Zambian Copperbelt, Central Africa.}

\author{
ZIERDT, K.', SINKALA, T. ${ }^{2}$, MASTER, S. ${ }^{3}$, LIMPITLAW, D. \\ 'Dept of Geological Sciences, University of Cape Town, \\ Rondebosch 7700, South Africa \\ ${ }^{2}$ School of Mines, University of Zambia, P.O.Box 32379, Lusaka, \\ Zambia \\ ${ }^{3}$ Economic Geology Research Unit, \\ ${ }^{4}$ Department of Mining Engineering, University of the \\ Witwatersrand, P Bag 3, WITS 2050, Johannesburg, South Africa
}

\footnotetext{
'Aining contributes significantly to the economies of many southern African Developing Countries (SADC). At a regional level, the contribution is about $60 \%$ of GDP. Since large scale mining began 60 years ago, environmental degradation in conjunction with mining activities has
}

occurred. In June 1995 the German Carl Duisberg

Gesellschaft (CDG) sponsored a SADC workshop in Harare, Zimbabwe, at which Regional Universities and Training Institutions (RUTI) met to discuss details of RUTI network activities. The development of an interdisciplinary GIStraining module in environmental impact assessment, using the Zambian Copperbelt as a case study, was one of the activities implemented. The goal of the case study is to develop a special system to determine the spread of pollution in the study area. The case study includes the following five phases:

I. Inventory of information related to the EIA of the Copperbelt Region;

II. The information and data is assessed to devise a method of analysis for a computer based EIAS;

III. Application of the devised method is used to log the typical contaminated sites in the study area;

IV. Development of a prototype training area; and V. Creation of a method handbook and teaching programs. The final system is used as a training module for RUTI with the aim of commercializing the material for Environment Impact Assessment System training.

\section{Hydrological Explanation of the Heavy Metals Concentration in the Wyszogrod Island (Vistula River near Plock, Poland)}

\author{
ZOBER, Steffen', MAGNUSZEWSKI, Artur ${ }^{2}$ \\ 'Johann Wolfgang Goethe-University, Georg-Voigt Str. 14, D- \\ 60325 Frankfurt am Main, Germany \\ ${ }^{2}$ Warsaw University, Krakowskie Przedmiescie 30, 00-927 \\ Warszawa, Poland
}

Alluvial sediments transported by rivers is considered to be one of the most dynamic natural processes. The sediments in the fluvial system can be temporarily stored at the surface of floodplains, channel bars, and islands. The middle reach of the Vistula River has preserved its natural braiding channel pattern with the large islands, but the water is also heavily polluted. Wyszogrod Island is more than 100 years old and the sequence of its sediments can be used for dating the environment pollution history. The development of the island has been studied using old topographic maps which have been calibrated by CAD-Raster program by affinite transformation. The sediment samples have been collected in three specified points and sequential chemical extractions for the partitioning of trace elements $\mathrm{Fe}, \mathrm{Mn}, \mathrm{Cr}, \mathrm{Cu}, \mathrm{Pb}, \mathrm{Zn}$, and $\mathrm{Ni}$ in different grain sizes carried out. The place of extremely high concentration of $\mathrm{Zn}$ (over $800 \mathrm{mg} \mathrm{kg}^{-1}$ ) acts as a kind of recent sediment trap where practically every year floods deposit some materials. The lower concentration of the pollution on the top layer confirms the recent improvement of the Vistula River environment. Study of the old maps, together with the hydrological interpretation of sediment deposition, helps to plan the field sampling and later understand results of heavy metals laboratory analysis.

This paper is a result of German - Polish cooperation within IHP IV UNESCO project "Floodplain pollution control - management". 


\section{Application of a Three Dimensional Coupled Transport and Equilibrium Chemistry Model to the Fate and Transport of Contaminants in the Konigstein Uranium Mine}

GUERIN, Marianne, LOWSON, Richard, and BROWN, Paul ANSTO, Environment Division, Environmental Chemistry Group, PMB1, Menai, NSW, 2234, Australia

During mining, ground waters are usually protected by modification of the aquifer structure and/or installation of contaminant collection drains. These operations and structures are abandoned following closure of the mine. Mine operators and regulators require demonstration that residual materials in the mine workings do not pose a threat to the integrity of the ground water following mine closure.

The presentation describes an extension to previous transport modeling work for the Konigstein Uranium Mine in Germany. In the past, the fate of a single species was modeled under different mine closure scenarios. The current work employs a coupled multi-species transport and geochemistry model. In this case, equilibrium geochemical speciation is calculated at appropriate intervals during the transport simulation. The coupled three-dimensional transport and equilibrium geochemistry code used in this study employs the transport code MT3D and the geochemical code PHREEQE as the base codes.

\section{Coupling Three Dimensional Transport with Geochemistry-MT3D and PHREEQE}

GUERIN', Marianne and $\mathrm{ZHENG}^{2}$, Chunmiao

'ANSTO, Environment Division, Environmental Chemistry Group, PMB1, Menai, NSW, 2234, Australia

${ }^{2}$ University of Alabama, Department of Geology, Tuscaloosa, $A L$

Currently, there are computer codes available that describe the three dimensional aqueous transport of contaminants and other codes that (separately) describe the equilibrium geochemistry of solutions. However, there is a lack of three dimensional codes that adequately describes both processes simultaneously. Historically, this has been an area of significant activity both in the nuclear and environmental protection industries.

The aim of this project is to produce a coupled code that describes the geochemistry and transport of contaminants through geological media, and to describe appropriate conditions under which model simulations will yield reasonable results. The intent is to produce a code that is accessible to industry by using existing, readily available, well-documented codes in the coupling scheme. 


\section{Index of Authors}

A

AFRODISIS, S. 84

AHLGREN, Malin 55

ALCORDO, Isabelo S. 75

AMACHER, M.C. 6

AMRO, H. 84

ANDER, E.L. 6

ANGEROTH, Cory 55

APPELHANS, Anthony D. 39

APPLETON, J.D. 24, 89

ARDELEAN, Gavril 94

ASAMI, Teruo 6

ASHLEY, Roger P. 7

ATKINS, David A 7, 44, 55

AUSTIN, Andrew Y. 87

ÄYRÄS, Matti 7, 67, 76

B

BAGTZOGLOU, Amvrossios C. 91

BAILEY, Elizabeth A. 8

BALISTRIERI, Laurie S. 8

BALL, T.K 89

BANNON, Michelle P 13

BARTA, J. 14

BASHKIN Vladimir N. 9

BATES, A.L. 69

BELKIN, Harvey E. 10

BERGER, B.R. 77

BERNER, Margit 38

BERNER, Zsolt 10

BEZUGLA, Maryna V. 83

3EZUIDENHOUT, Nico 10

BHATIA, S. 39

BIENIULIS, C. 11

BILLETT, Michael F. 87

BIRCH, Gavin F. 11, 61, 90

BIRD, Dennis K. 69

BIRKE, Manfred 11, 12

BLICKWEDEL, R. 25

BLISS, Linda N. 12, 55

BOGATYREV, I. 76

BONDAR, Galina S. 12

BONHAM-CARTER, G.F. 13

BONI, Maria, 19

BOOKSTROM, Arthur A. 8

BOTHNER, M. 37

BOURG, Alain C. M. 13, 43

BOWELL, R.J. 14, 22

BOX, Stephen E. 8

BOYD, R. 76

BOYLE, Dan R. 53

BRANDVOLD, L. A. 14,63

BRIGGS, Paul H. 17, 86

BRIL, Hubert 13

BROTHWOOD, Susan J. 70

BROWN, C.J. 85

BROWN, Kevin L. 15

BROWN, Paul 101

BROWN, R.W. 6

RUSSELMANS, A. 93

BUCHHOLTZ TEN BRINK, Marilyn 37, 59

BUDEK, L. 36

BURLAK, A.V. 46

BUSCHE, U. 37
C

CAMERON, Eion M. 15

CAMPBELL, Angus N. 72

CARON, François 16

CARRANZA-EDWARDS, A. 16,77

CARUTHERS, K. 30

CASSO, M. 37

CASTRO, Javie, 73

CHAFFEE, M.A. 16, 30

CHAIKEN, R.F. 18

CHAN, Rachael 54

CHANEY, Rufus L. 26

CHASTAIN, E. A. 34

CHEKUSHIN, Viktor 67, 76

CHEN, Hongmin 95

CHENNERY, S.R.N. 85

CHEONG, Young-Wook, 17

CHON, Hyo-Taek 44, 52

CHURCH, Stanley E. 17

CLINE, David J. 78

CLOSS, L. Graham. 28

COETZEE, H. 99, 100

COLES, Barry J. 54

CONNELLY, R.J. 14, 22

CONSTANTINOU, C. 84

CONSTANTINOU, G. 84

COOK, J. 85

COOK, Terri L. 7, 44

COOPER, C.S. 73

CORTECCI, Gianni 17

COSTABILE, Salvatore 19

COURCHESNE, F. 27

COWAN, J. 14

CRONIN, Mark T.P. 21

CUNHA, F.G. 18

D

DALVERNY, L.E. 18

DAVIS, Andy 21

de BRUIN, D. 18

DE CARITAT, Patrice 67,76

De VILLIERS, A.B. 99, 100

DE VIVO, Benedetto 19

DEISSMANN, Guido 19

DeLIMA, Edmilson S. 19

DESILETS, Mario O. 51

DINELLI, Enrico 17, 20

DODDS, Heather A. 20, 93

DOIDGE, Bill 15

DOMAGALSKI, Joseph L. 21

DRAKE, P. L. 50

DREVER, James I. 88

DUDAR, Tamara V. 83

DUPON, Daniel P. 78

DUTTER, R. 76

E

EARY, L. Edmond 21

ECHA-ERNSTBERGER, J. 34

ECKELHOPF, A. 37

EDWARDS, Grant C. 74

EDWARDS, P. 14, 22

EDWARDS, Robert 21, 23, 75

EINAUDI, Marco T. 69

ELLIS, J. 14

ELSENBROEK, J.H. 18 
ERICKSON, Tyler A. 53

ERZINGER, J. 49

ESPIRITO SANTO, Lidiane S. do 19

ESPOSITO, Kenneth J. 53

EVANGELOU, V.P. 22, 93

EVANS, Andrew, Jr. 23

EVSTAFJEVA, Elena V. 9

\section{F}

FANNIN, Craig 23

FARAGO, Margaret $6,23,39,43,56,92,96$

FAURE, Gunter 72

FERGUSON, C. 92

FERRARI, Carlo 20

FEY, Martin V. 10, 20, 28, 33, 34, 46, 51, 68, 71, 75, 93

FINKELMAN, Robert B. 10

FINN, C.A. 77

FINNE, T.E. 76

FLOHR, Marta J.K. 24

FLORENCIO, L. 19

FORDYCE, F. M. 24

FORGÁČ, Jozef 64

FORTIER, I. 27

FREERS, J. 85

FRICKE, J. 25

FUGE, Ron 25, 70, 71

FÜGEDI, Ubul 68

FUMOTO, Tamon 26

G

GAO, Xiaojiang 26, 95

GARBE-SCHÖNBERG, Dieter 61

GARRETT, Robert G. 26

GAUTHIER, E. 27

GAUTHIER, G. 33

GAUVREAU, D. 27

GE, X. 24

GEDEON, R. 84

GENNADIYEV, A. 27

GETTINGS, M.E. 77

GILL, P. 37

GILLIGAN, E. 39

GLANZMAN, Richard K. 28

GLÄSSER, Cornelia 27

GLÄSSER, Walter 27

GLENDINNING, John 28

GOBAS, Frank A. 11

GOESSLER, W. 43

GOLDFARB, Richard J. 31

GOLOVATIY, Sergei 80

GOLOVKO, Natalia V. 28

GONZALEZ, Luz Miryan 29

GOODFELLOW, Wayne D. 53

GOUGH, Larry P. 47, 50

GOVIL, P.K. 29

GRABOWSKI, Josef 21

GRANEY, J. 37

GRATH, Johannes 49

GRAY, David J. 30

GRAY, F, 30

GRAY, John E. 8, 31

GREEN, Carrie E., 26

GROENEWOLD, Gary S. 39

GUERIN, Marianne 101

GULSON, Brian L. 31

GUNDERSEN, L. C. 32
GUO, Tao 71

GUO, X. 11

GURRIERI, J.T. 32, 65

\section{H}

HAGERTY, P. 25

HÄLBICH, Torsten 33

HALL, G.E.M. 15, 26, 33, 39

HALLERAKER, J.H. 76

HALLEY, Robert B. 37, 77

HAMMARSTROM, Jane M. 24

HAMPTON, C. 85

HANLEY, James E. 72

HARCK, Terry 34

HARRISON, Wendy J. 34, 40

HARSBO, Kristina 55

HATTA, T. 58

HAVIS, Robert N. 35

HAWKINS, J. 39

HEINRICHS, Gerold, 35

HELIOS RYBICKA, E. 36

HENDERSON, P.J. 63

HINDEL, R. 93

HINES, Mark E. 8

HIRNER A.V. 36,37

HOFFMAN, J.D. 16

HOLMES, C. 37

HOOGEWERFF, Jurian A. 37, 38, 48, 86

HOOVER, Donald B. 53

HORN, Barbara J., 97

HORVÁTH, István 68

HOUSER, B.B. 77

HUAMING, Guo 95

HUDSON-EDWARDS, Karen A. 38

HUNT, Andrew 39

HUTCHINS, M. 84,85

HUTCHINSON, E.J. 39

I

IKRAMUDDIN, Mohammed 8

INGRAM, Jani C. 39

IRGOLIC, K. 43

J

JÆGER, Ø. 76

JAKEL, M. Emmellyn 46

JAMESON, C.W. 31

JAMIESON, Heather 33, 51

JERZ, Jeanette K. 40,86

JOHNSON, C. C. 24

JONES, D.G. 89

JONES, Richard L. 78

JORDAN, David L. 40

JOSHI, D.C. 40

$\mathbf{K}$

KABATA-PENDIAS, Alina 41

KADATSKAYA, Olga V. 41

KADATSKY, Valery B. 42

KAGAN, Leonid M. 42

KAMEWADA, K. 58

KAPINUS, Evgeny I. 42

KARPOVA, Tamara P. 12

KASHULINA, G. 76

KASIMOV, N.S. 43

KAUFMANN, H. 49 
KAVANAGH, P.J. 43

KAZANTZIS, G. 23

KEDZIOREK, Monika A. M. 13,43

KEELER, G. 37

KELLEY, Karen D. 31, 44

KELLY, Eugene 23

KEMPTON, J. H. 7, 12, 44, 55

KHANNA, P.P. 65

KHARITONOV, Nikolaj N. 12

KIM, A.G. 18

KIM, Kyoung-Woong 44, 52

KING, T.V.V. 77

KISTINGER, Stephan 19

KLASSEN, Rodney A. 45

KLAVINA, I. 45

KLAVINS, M. 45

KLINE, E. 50

KLUSMAN, Ronald W. 46

KNESL, Oliver 46

KOMOV, I.L. 46

KORENCHUK, Ludmila V. 42

KORKEALAAKSO, J. 56

KOROLEVA, T.V. 43

KOROLOVA, E. G. 58

KOROMYSLICHENKO, Taisia I. 28

KORSCH, Michael J. 31

KOTRA, Rama K. 47

KOTUBY-AMACHER, J. 6

KOVALEVSKII, Alexander L. 47, 48

KOZIN, I. 27

KRALIK, Martin 38, 48, 49

KREISER, Brian R. 60

KRÜGER, G. 49

KRUPP, E. 36

KUBOTA, Masatsugu 6

KUMAR, Suresh 50

KURZ, Heidi 73

KWON, Kwang-Soo 17

\section{L}

LAMBETH, R. H. 50

LANYON, Ruth 51

LBOV, Alexander V. 47

LEAHY, P. Patrick 51

LECHLER, Paul J. 51

LEE, Gregory K. 52

LEE, Jin-Soo 52

LEHTO, O. 76

LEINZ, Reinhard W. 53

LEPP, Nicholas W. 75

LERCH, H.E. 69

LeROY, Michael P. 46

LEVY, David B. 53

LEYBOURNE, Matthew I. 53

LI, Shan-Fang, 54

LI, Xiangdong 54

LI, J. 24

LIBLIK, Valdo 74

LICHTE, F.E. 30,77

LIMPITLAW, D. 100

I.IN, Zhixun 55, 97

IND, C.J. 55

LIU, Shujuan 26, 95

LIU, X 24

LIVI, Ken J.T. 67

LOCKE, William W. 55
LOMBARD, M. 18

LOMBINI, Allessandra 20

LOPEZ, Dina L. 69

LOUKOLA-RUSKEENIEMI, Kirsti 56

LOVELL, Anthony 75

LOWSON, Richard 101

LOYD, David H. 78

LUKIN, Anatolyi A. 84

LUND, D. 56

LUUKKONEN, A. 56

\section{M}

MACHADO,G.J. 18

MACKINNON, Robert J. 40

MACKLIN, Mark G. 38

MACLAURIN, Alice I. 26

MAGIERA, Tadeusz 57, 88

MAGNUSZEWSKI, Artur 57, 100

MAHAFFEY, Kathryn R. 31

MAISENBACHER, Peter 73

MAJER, Vladimír 58

MAKINO, Tomoyuki 58, 79

MALKHAZOVA, Svetlana M. 58

MANHEIM, Frank T. 59

MANNI, Giulio 16

MARGOLINA, Sofia E. 59

MAROT, M. 37

MARRS, Ronald W. 96

MARTIN, Lori M. 60

MASTER, S. 100

MATEJKA, Guy 13

MATSCHULLAT, Jörg 60,61

MATTHAI, C. 61

MAZEIKA, Jonas 62

McCAFFREY, Lewis P. 62

McCARTAN, Lucy 63

McCLENAGHAN, M. Beth 74

McCURDY, Martin 15

MCDONALD, Richard R. 55

McHUGH, M. 44

McKNIGHT, Diane M. 88

McLEMORE, V. T. 14, 63

McMARTIN, I. 13, 63

McNEAL, James M. 51, 64

MEIER, Allen L. 86

MEJEED, Salem Yaseen 64

MELLO, C.S.B. 18

MERCHANT, David 21

MIELKE, Howard W. 64

MIHAI, Mihaela 94

MILLER, Rebecca A. 65

MIN, Jung-Sik 17

MITTON, Jeffry B. 60

MIZON, Karen J. 31

MIZUI, Chizuru 6

MONTOROI, J.P. 65

MOORE, A. 45

MOORE, J.C. 53

MOREHEAD, N. 37

MORTIMER, J. 27

MUKHERJEE, P.K. 65

MUSSI, Mario 17

MYUNG, Jae-Hoon 44 


\section{$\mathbf{N}$}

NAGY, Wilhelm 49

NEWCOMER, Robert W. 40

NI, Dagang 66

NICHOLSON, Andrew D. 12

NICHOLSON, Keith 66, 91

NISKAVAARA, Heikki 67,76

NOGAMI, Naoko 6

NORD, Gordon L., Jr. 67

NOWICKI, Tom 68

\section{o}

Ó.KOVÁCS, Lajos 94

ÓDOR, László 68

OREM, William H. 69,99

OVERLY, Bryan M. 69

\section{$\mathbf{P}$}

PARACHINI, Richard 97

PARKER, A. 73

PARSONS, Michael B. 69

PAUKOLA, Tarja 56, 90

PAULSON, A. J. 50

PAVLOV, Vladimir 67,76

PEARCE, Nicholas J.G. 25, 70, 71

PEITER, Gerhard 61

PELCHAT, J.C. 33

PENDLETON, James A. 72

PEPER, John 63

PEPIN, P. 27

PERKINS, William T. 25, 70, 71

PESTKE M. 37

PETERS, A. 73

PETROSIUS, Rimantas 62

PHILIPPITSCH, Rudolf 49

PIKOVSKII, Yu 27

PING, Ren 71

PITKÄNEN, P. 56

PLÜGER, W.L. 19

POLICHTCHOUK J.V. 46

POOLEY, Justin 71

POON, Chi-sun 54

POSEY, Harry H. 72

POWELL, J.H. 84

PRÉVOST, Clément 15

PRIDE, Douglas E. 72

PRIETO, Gloria R. 72

PRIPUTINA Irina V. 9

PROSKURYAKOV, U.V. 43

PUCHELT, Harald 10, 73, 81

PUGINIER, Barbara 13

PUROHIT, K.K. 65

\section{$\mathbf{R}$}

RAE, J.E. 73

RÄISÄNEN, M. L. 7, 73, 76

RAMSEY, Michael H. 54, 92

RANVILLE, James F. 40, 86

RASHED, M.N. 74

RASMUSSEN, Pat E. 74

RATHI, M.S. 65

RÄTSEP, Aavo 74

RAUCH, Uwe 11, 12

RAWLINS, B. 85

REBEDEA, Irina 75

RECHCIGL, Jack E. 75
REID, Caroline 75

REIMANN, Clemens 67, 76

REN, TianXiang 54

RENCZ, A.N. 45

RENDIGS, R. 37

RICHARDS, D.G. 6

RIDLEY, W. I. 77

RINKE, Mariusz 13

ROBBINS, Eleanora I. 67, 87

ROBBINS, J. 37

ROBINSON, Charles S. 72

RODINOV, V. 45

ROMER, Rolf L. 81

ROSALES-HOZ, L. 16, 77

ROTTER, Heinrich 48

ROULIER, Leanne M. 77

ROZKO, Alla N. 28

RUDNICK, D. 37

RUNNELLS, Donald D. 78

RUSS, Jon 78

RUTAKINGGIRWA, M. 85

RYTUBA, James J. 78

$\mathbf{S}$

SADOVNIKOVA, Ludmila K. 59

SAINI, N.K. 65

SAKURAI, Yasuhiro 58, 79

SAMSONENKO, Igor P. 42, 79

SANGSTER, AI L. 74

SAVCHENKO, Vladimir 79, 80

SCHAEFER, Joerg 81

SCHARNWEBER, Tim 61

SCHETTLER, Georg 81

SCHRAMKE, Janet A. 53

SCHROEDER, Bill H. 74

SCHULZ, F. 36

SCULLY, Patricia 21

SEAL, Robert R. II 82

SELINUS, Olle 82

SELLSTONE, Christopher M. 12

SEMENOV, Yury M. 82

SEMENOVA, Lyudmila N. 82

SETA, A. K. 22, 93

SHAKHVERDOV, V. 83

SHAND, P. 85

SHANKS, W.C. III 77

SHARMA, K.D. 40,50

SHARMA, B.K. 50

SHILLER, Alan M. 90

SHINN, G. 37

SHTANGEEVA, Irina 83

SHUMLYANSKIY, Vladislav O. 83

SHVARTSEV Stepan L. 84

SILVA, Maria do Carmo T. 19

SIMMONS, Kathleen R. 99

SIMON, J. I. 34

SIMONI, Andrea 20

SIMPSON Peter R. 23, 39, 87

SINKALA, T. 100

SMITH, B. 84,85

SMITH, Kathleen S. 86

SMITH, M. Kelley 64

SONKE, Jeroen 86

SPERRING, Timothy 25

SPILNY, Sergey A. 42

SRIRAM, V. 65 
JSSERUNJOGI, L. 85

ST. CLAIRE GRIBBLE, K. 39

STAESSEN, Jan 37

STAINES, Russell 87

STANTON, Mark R. 87

STCHOGOLEV, Aleksandr K. 42

STEELE, Kenneth F. 87

STOTHOFF, Stuart A. 91

STRAND, T. 76

STRUTT, M.H. 89

STRZEBONSKA, M. 36

STRZYSZCZ, Zygmunt 57, 88

STYLES, M. 85

SULLIVAN, Annett B. 88

SUN, Jingxin 95

SUTLEY, Stephen J. 86

SWAYZE, Gregg A. 87

SWEDLUND Peter J. 96

SWENNEN, R. 88, 93

\section{$\mathrm{T}$}

TAGUTSCHI, Yuhsaku 89

TAKAHASHI, Yoshiaki 58, 79

TALBOT, D.K. 89

TANOVITSKAY, Nina 79

TARVAINEN, Timo 90

TAYLOR, Cliff D. 31

TAYLOR, Howard E. 90

TAYLOR, Mark P. 38

TAYLOR, Stuart E. 11,90

TENHOLA, Markku 56

TEPLITSKAYA, T. 27

THOMSON, Bruce 91

rHORNTON, Iain 6, 23, 39, 43, 54, 56, 92, 96

TIBERINDWA, J.V. 85

TIDBALL, R.R. 16

TOLAND, Harry 71

TOLLEY, Timothy L. 91

TOMKINS, A. 85

TRICK, J.K. 84

TRISTÁN, E. 92

TURNER, David R. 91

$\mathbf{U}$

UDLUFT, Peter 35

UERPMANN, Carsten 60

UUTELA, Anneli 56

$\mathbf{V}$

VAN DER LAAN, Sieger 86

VAN DER SLUYS, J. 88, 93

VAN GOSEN, B.S. 16

VAN TIENHOVEN, Mieke 93

VANDIVIERE, M. M. 93

VANGRONSVELD, Jacco 86

VARGAS, Orlando 29

VARSÁNYI, Irén 94

VATCA, Gheorghe 94

VAUGHN, Robert B. 87

VERKEYN, M. 88

VESELSKÝ, Josef 64

ESELÝ, Josef 58

$\checkmark$ IMAN, Vasile 94

VOGEL, Wilhelm 49

VOLDEN, T. 76

VOROGEYKIN, A.P. 43
W

WALLACE, Peter 21

WALTON-DAY, Katherine 86

WANDLESS, Gregory A. 82

WANG, Bronwen 95

WANG, Lijun 26, 95

WANG, Y. 92

WANG, Yanxin 95

WANG, Yong 96

WANG, Yuqi 26, 95

WANTY, Richard B. 68,77

WAWRZYNSKI, Alecia L. 96

WEBSTER Jenny G. 15, 96

WEBSTER Kerry S. 15, 96

WEI, Chaoyang 99

WEN, Dongguang 97

WENDLANDT, R. F. 34

WHITE, Richard A. 70

WILLIAMS, Geoffrey M. 13

WILLIS, James P. 10, 28, 33, 34, 46, 51, 62, 71, 75, 93

WILLSON, Jeanne 9

WILSON, Stephen A. 17, 53

WIRT, L. 30

WIRTH, Volker 61

WOOD, A. 14, 22

WOOD, John 66

WOODLING, John D. $60,72,97$

$\mathbf{X}$

XIMING, Yuan 95

$Y$

YAO, Hua 97

$\mathbf{Z}$

ZENG, Jianhua 97

ZHAMOIDA Vladimir A. 98

ZHANG, Chaosheng 82

ZHANG, Fuquing 98

ZHANG, Licheng 99

ZHANG, Shen 26, 95

ZHANG, Xuelin 98

ZHANG, G. 24

ZHANG, Q. 24

ZHENG, Baoshan 10

ZHENG, Chunmiao 101

ZHOU, Liyi 71

ZHURAVEL, Nickolay E. 83

ZIELINSKI, Robert A. 99

ZIERDT, K. 99, 100

ZOBER, Steffen 100

ZUBKOV Andrei A. 84 